Doktori $(\mathrm{PhD})$ értekezés

\title{
KÜLFÖLDI KAJSZIFAJTÁK ADAPTÁCIÓS ÉRTÉKELÉSE A VIRÁGRÜGYFEJLŐDÉS, A FAGYÉRZÉKENYSÉG ÉS A GYÜMÖLCSMINŐSÉG VIZSGÁLATA ALAPJÁN
}

\section{Hajnal Veronika}

\author{
Témavezetö: \\ Dr. Szalay László, PhD \\ egyetemi docens \\ Budapesti Corvinus Egyetem \\ Kertészettudományi Kar \\ Gyümölcstermő Növények Tanszék
}

Budapest

2015. 
A doktori iskola

megnevezése: $\quad$ Kertészettudományi Doktori Iskola

tudományága: Növénytermesztési és Kertészeti Tudományok

vezetője: $\quad$ Dr. Tóth Magdolna

egyetemi tanár, DSc

Budapesti Corvinus Egyetem, Kertészettudományi Kar, Gyümölcstermő Növények Tanszék

Témavezető: $\quad$ Dr. Szalay László

egyetemi docens, $\mathrm{PhD}$

Budapesti Corvinus Egyetem, Kertészettudományi Kar,

Gyümölcstermő Növények Tanszék

A jelölt a Budapesti Corvinus Egyetem Doktori Szabályzatában előírt valamennyi feltételnek eleget tett, az értekezés mühelyvitájában elhangzott észrevételeket és javaslatokat az értekezés átdolgozásakor figyelembe vette, azért az értekezés védési eljárásra bocsátható. 
A Budapesti Corvinus Egyetem Élettudományi Területi Doktori Tanács 2015. december 8ki határozatában a nyilvános vita lefolytatására az alábbi Bíráló Bizottságot jelölte ki:

\title{
BÍRÁLÓ BIZOTTSÁG:
}

Elnöke

Pénzes Béla, CSc

\author{
Tagjai \\ Hegedüs Attila, DSc \\ Rozsnyay Zsuzsanna, CSc \\ Kovácsné Békefi Zsuzsanna, PhD \\ Pál Magda, PhD \\ Opponensek \\ Halász Júlia, $\mathrm{PhD}$ \\ Szabó Zoltán, DSc
}

Titkár

Karacs-Végh Anita, PhD 


\section{Tartalomjegyzék}

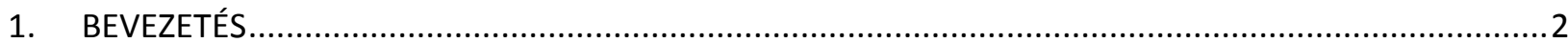

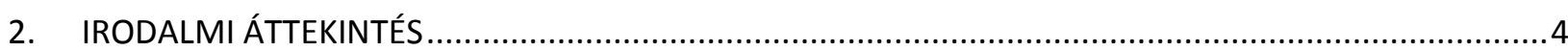

2.1. A kajszi eredete, rendszerezése és elterjedése ............................................................................

2.2. A kajszitermesztés nemzetközi és hazai helyzete, fajtahasználat ................................................. 6

2.3. Nemesítési trendek és nemesítő mühelyek.......................................................................................

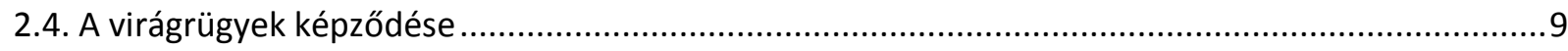

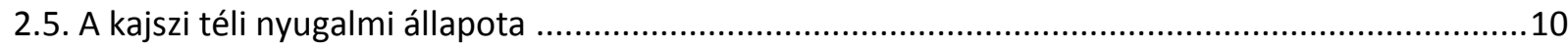

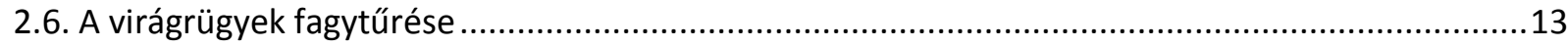

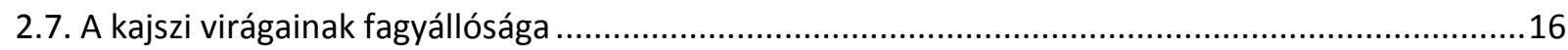

2.8. A fagykár kialakulásának élettani és genetikai háttere ................................................................16

2.9. A kajszi táplálkozásbiológiai jelentősége és felhasználása.............................................................18

2.10. A gyümölcsök fizikai jellemzőinek változása az érés során ..........................................................20

2.11. A gyümölcsök kémiai jellemzőinek változása az érés során .......................................................22

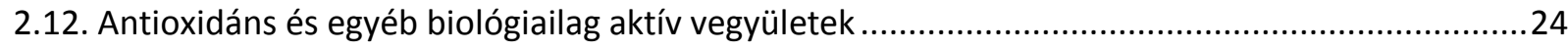

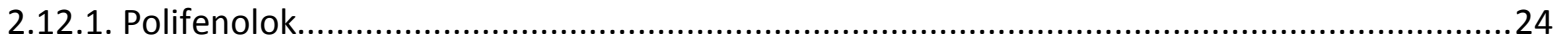

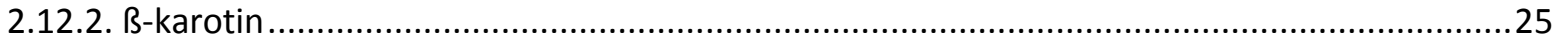

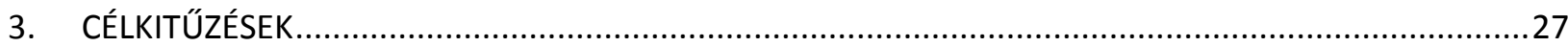

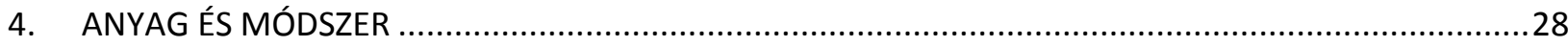

4.1. A kísérleti minták származási helye, a termőhely adottságai .....................................................28

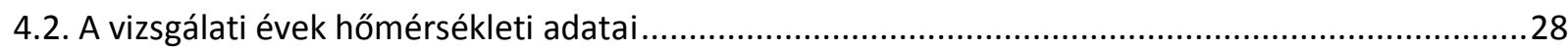

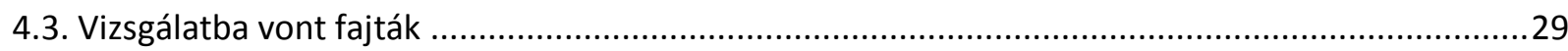

4.4. A virágrügyek és a virágok fagykárosodásának meghatározása mesterséges fagyasztással............30

4.5. A mikrosporogenézis folyamatának vizsgálata a kiválasztott kajszifajtákban ..................................32

4.6. Kajszifajták fizikai paramétereinek meghatározása ......................................................................33

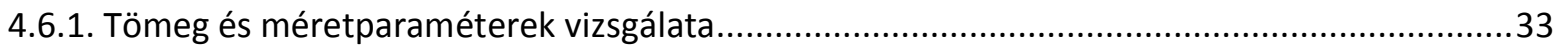

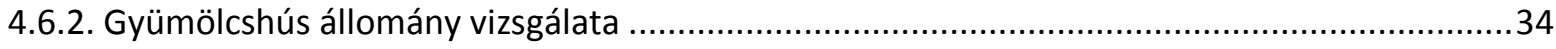

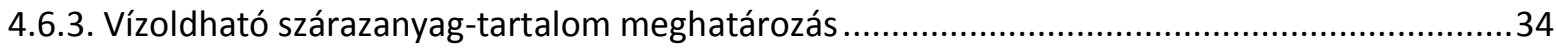

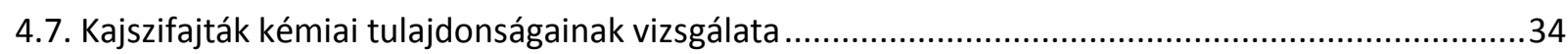

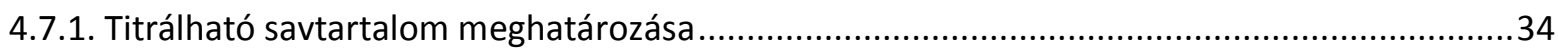

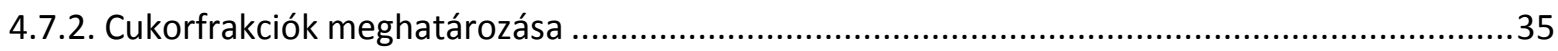

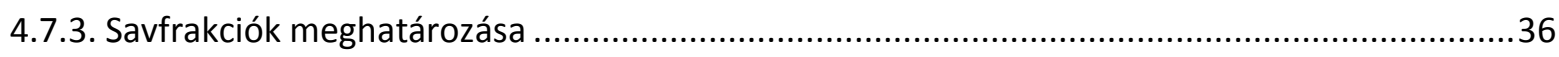

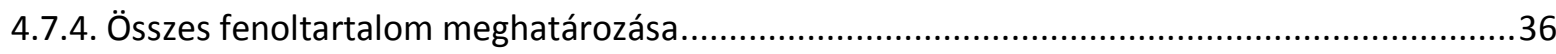

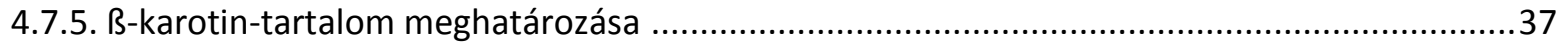


5.1 Kajszifajták virágrügyeinek és virágainak fagytűrése a mesterséges fagyasztásos kísérletek eredményi alapján......

5.1.1 A virágrügyek fagykárosodása a téli nyugalmi időszakban ..............................................41

5.1.2 A virágzási időszakok fagytűrési vizsgálatainak eredményei ..............................................54

5.2 A három évjárat fagytűrési eredményeinek összehasonlítása..............................................57

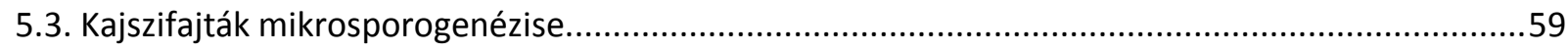

5.4. Az áruértéket meghatározó fizikai tulajdonságok ...........................................................63

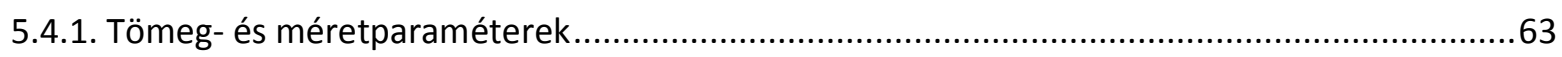

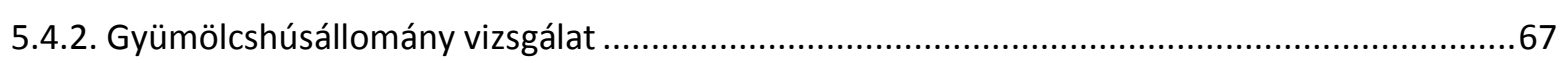

5.4.2.1 Kajszifajták húskeménységének alakulása a kézi penetrométeres eredmények alapján.......67

5.4.2.2. Kajszifajták húskeménységének és állományparamétereinek vizsgálata műszeres méréssel

5.5. A fogyasztói megítélést befolyásoló beltartalmi tényezők ..................................................78

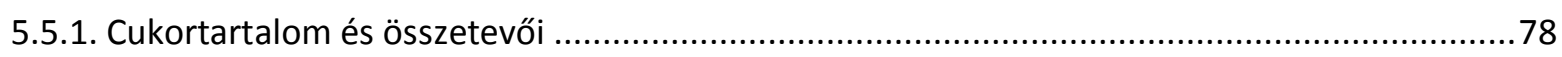

5.5.1.1. Vízoldható szárazanyagtartalom vizsgálata .................................................................78

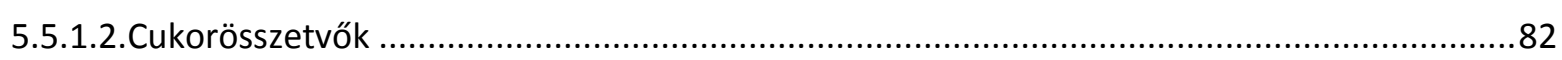

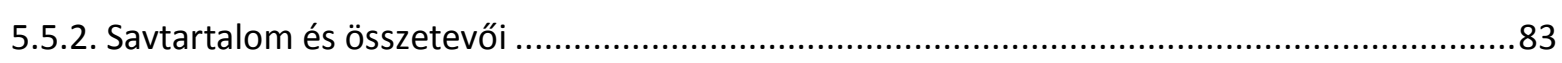

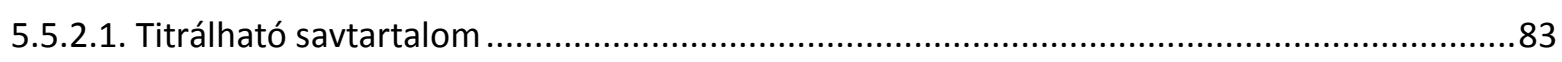

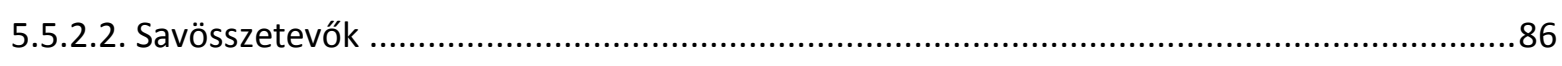

5.5.3. Kajszifajták vízoldható szárazanyag- és összes savtartalmának összefüggései ........................87

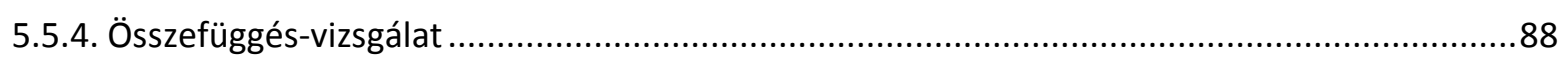

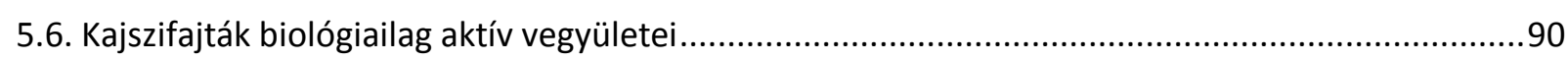

5.6.1. Kajszifajták polifenol-tartalmának értékelése ..........................................................90

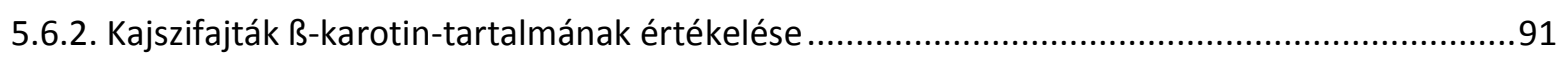

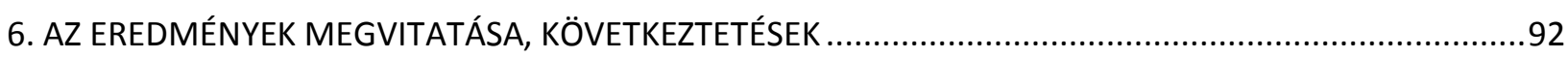

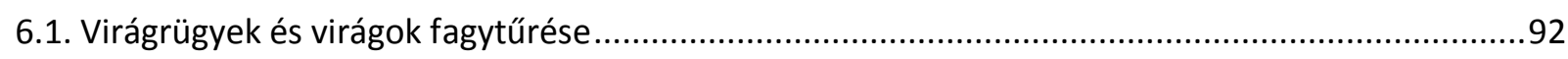

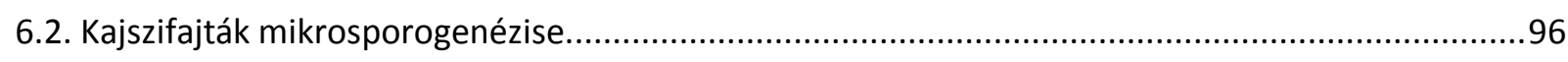

6.3. Kajszifajták áruértékét meghatározó tulajdonságok ...............................................................98

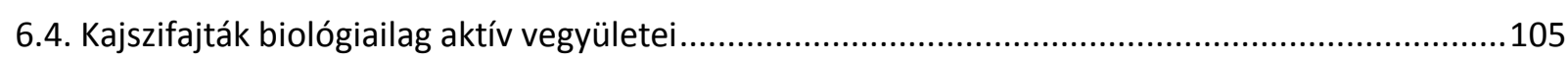

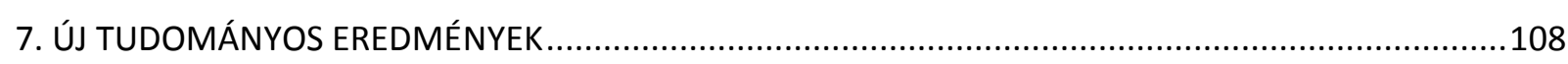

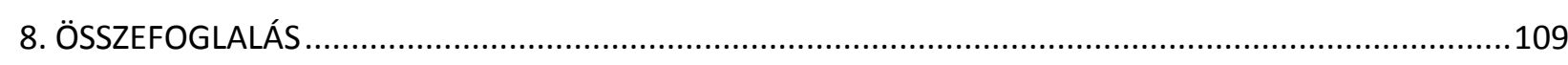

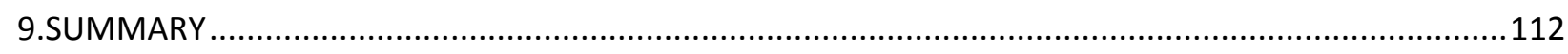

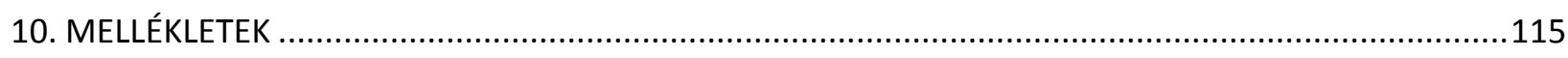

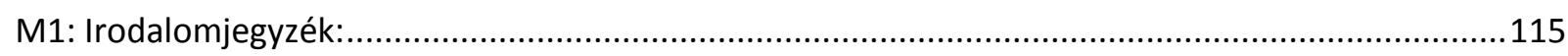


M2. Táblázatok

M.3. Ábrák

11. KÖSZÖNETNYILVÁNÍTÁS 


\section{RÖVIDÍTÉSEK, JELÖLÉSEK JEGYZÉKE}

AFP Anti Freeze Protein

AM Amerika

ANOVA Analysis of Variance

Ca EDTA Calcium disodium ethylene diamine tetraacetate

CB Ceglédi bíborkajszi

CBF C-repeat Binding Factor

COR Cold Regulated Genes

FAO Food and Agriculture Organization of the United Nations

GÖ Gönci magyar kajszi

HPLC High Performance Liguid Cromatography (High Pressure Liguid Cromatography): nagy hatékonyságú/ nyomású folyadék kromatográfia

LT Lethal temperature

KPKI Konzervipari Kutató - Fejlesztő és Minőségvizsgáló Kht

MANOVA Multivariate Analysis of Variance

MgSZH Mezőgazdasági és Szakigazgatási Hivatal

MK Mandulakajszi

NAIK Nemzeti Agrárkutatási és Innovációs Központ

NÉBIH Nemzeti Élelmiszerlánc-biztonsági Hivatal

ORR Orange Red

Ro Románia

RÓ Rózsakajszi C. 1406 


\section{BEVEZETÉS}

A kajszi (Prunus armeniaca L.) Kínából származó, melegigényes gyümölcsfaj, hazánk területén több évszázados hagyománya van a termesztésének. Gyümölcse igen értékes tulajdonságokkal (magas rosttartalom, alacsony energiatartalom) bír, ezért kiemelkedő szerepet tölt be az egészséges táplálkozásban. Jelentős mennyiségben tartalmaz $\mathrm{C}$-vitamint, $\mathrm{B}_{1}$ és $\mathrm{B}_{2}$ vitamint, magas a kálium-, kálcium-, foszfor- és magnéziumtartalma. Kiemelkedő karotintartalommal rendelkezik, amely fontos szerepet játszik az erős immunrendszer fenntartásában. Kedvező hatással van a zsíranyagcserére, serkenti a máj méregtelenítő folyamatait, védi a sejteket a károsodástól. Friss gyümölcsét csak rövid ideig, de feldolgozott termékeit egész évben tudjuk fogyasztani.

A kajszi gyümölcse a külföldi piacokon is jól értékesíthetö. A nemzetközi piacon komoly versenyfeltételeknek kell megfelelni, jelentős versenytársaink az olasz, a francia és a spanyol kajszitermesztők. Csak kiváló minőségü, tetszetős, jól színeződő, nagy gyümölcsű, jól szállítható és pulton tartható fajtákkal lehetünk versenyképesek. A jó piaci pozíciók eléréséhez a termesztett fajták érésbiológiai jellemzőit és gyümölcsminőségi paramétereit a lehető legrészletesebben kell ismernünk.

Napjainkban a kajszinemesítés legfontosabb célkitüzései közé tartozik a gyümölcsminőség javítása mellett a fajták abiotikus és biotikus stresszel szemben való ellenállóságának fokozása. A kajszit rossz ökológiai alkalmazkodó képessége, elsősorban fagyérzékenysége miatt csak bizonyos termőhelyeken tudjuk gazdaságosan termeszteni. Termésbiztonságát jelentősen befolyásolják a téli és a tavaszi fagykárok. A kajszifajták értékelésének fontos szempontja az áttelelő szerveik fagytürő képességének meghatározása. A termőhely kiválasztásánál is nagyon gondosan kell eljárni, a kajszi számára a fagykárok által kevéssé veszélyeztetett, dombvidéki termőhelyek a legalkalmasabb termesztő területek. Magyarországon az ültetvények fajtaösszetétele és a termőhely helytelen megválasztása miatt gyakori a terméskiesés és nagy a termésmennyiség évenkénti ingadozása.

A fajtaválaszték folyamatos fejlesztésre, bővítésre szorul, amiben nagyon fontos szerepe van egyfelől a hazai nemesítői munkának, másfelől a külföldön nemesített új kajszifajták honosításának. Olyan fajtákkal kell bővíteni a fajtaválasztékot, melyek hosszú mélynyugalmúak, s a jó fagy- és téltürés mellé kiváló gyümölcsminőség is párosul. Éppen ezért részletesen meg kell vizsgálni az újonnan nemesített kajszi genotípusok virágrügyeinek és virágainak fagy- és téltürését, valamint a különböző fajták mikrosporogenézisének ütemét. Vizsgálni kell továbbá a 
gyümölcsök fogyasztói megítélését is meghatározó fizikai és kémiai tulajdonságait, beltartalmi jellemzőit illetve egészségvédő értékét, ezáltal termesztésre való alkalmasságát.

Három éves munkám során ezekre a kutatási területekre helyeztem a hangsúlyt. Olyan külföldi nemesítésü kajszifajtákat vontam vizsgálatba, amelyekről még kevés hazai tapasztalat és kutatási eredmény áll rendelkezésre. Összehasonlító fajtákként régóta termesztésben lévő magyar kajszifajtákat választottam. 


\section{IRODALMI ÁTTEKINTÉS}

\subsection{A kajszi eredete, rendszerezése és elterjedése}

A hazánkban termesztett csonthéjas gyümölcsfajok közül a kajszi az egyik legjelentősebb. Rendszertanilag a Rosaceae család, Prunoideae alcsalád, Prunus L. nemzetségébe tartozik. A legtöbb termesztett kajszifajtát a Prunus armeniaca L. (szinoním néven Armeniaca vulgaris L.) faj adja, de a kajszi név több fajt is magába foglal. Kajszi néven ismert a Prunus armeniaca L., a Prunus armeniaca v. ansu Komar, a Prunus brigantina Vill., a Prunus holosericea Batal, a Prunus mandshurica (Maxim) Koehne, a Prunus mume Sieb., a Prunus sibirica L., a Prunus $x$ dasycarpa Ehrh (Layne et al., 1996; Mehlenbacher et al., 1990). Kajszilva néven ismert a (Prunus armeniaca L. $\times$ Prunus salicina Lindl.), a kajszi és a japán típusú szilva keresztezésével létrejött fajhibrid (Manganaris et al., 1999; Ahmad et al., 2004). A helyi termesztésben jelentős még az Armeniaca mume Sieb.(japán kajszi), az Armeniaca mandsurica Skvortz. (mandzsu kajszi), és az Armeniaca sibirica Lam (szibériai kajszi) is (Surányi, 2003). Az Armeniaca vulgaris elnevezés Örményországból származik (Morikian, 1983; Hormaza et al., 2007), termesztésbe vonása több ezer éve kezdődött meg Ázsiában (Faust et al., 1998).

A kajszi Kína északi, észak-keleti hegységeiből származik (De Candolle, 1894; Vavilov, 1926; Yuan et al., 2007). Vavilov (1992) cit. Hagen et al. (2002) a kajszinak három géncentrumát említi: Kínai központ (Észak-kelet-, Közép- és Nyugat-Kína hegyei); KözépÁzsiai központ (Tien-Shan hegyei, Hindukustól Kasmírig); Közel-keleti központ (Kaszpi-tenger nyugati hegységei, Azerbajdzsán, Örményország, Törökország, Észak-Irán). Észak-Kína területén található az Armeniaca mandshurica, az Armeniaca sibirica és az Armeniaca davidiana optimális termőhelye, ettől délebbre őshonos a többi faj, többek között az Armeniaca vulgaris is. A 38. szélességi fok alatt található az Armeniaca mume őshazája, míg ugyanabban a zónában, de a magashegységekben van a tibeti sárgabarack természetes élőhelye (Surányi, 2011).

Származásuk szerint a kajszifajták természetes rendszerbe sorolhatók, a fajtaállomány a fajok keveredésével jött létre. Kialakulásuk szerint Kosztina (1956) cit. Tomcsányi (1959) négy ökológiai-földrajzi csoportot különböztetett meg:

- Közép-ázsiai csoport: legősibb, fajtákban gazdag csoport; a fajták hosszú mélynyugalmúak, fagytürőek, önmeddők; gyümölcseik kisméretüek és magas cukortartalmúak 
- Mandzsúriai-szibériai csoport: az ide tartozó fajták a mélynyugalmi időszakban nagyon fagytürők, de mivel származási helyüktől délre hamar elkezdődik a vegetációjuk, ezért elvesztik fagytürőképességüket.

- Iráno-kaukázusi csoport: az ide tartozó fajták rövid mélynyugalmúak, fagyérzékenyek és önmeddők; gyümölcseik aszalásra alkalmasak.

- Európai csoport: ez a legkisebb alakgazdagsággal rendelkező csoport, a fajták többnyire öntermékenyülők, rövid mélynyugalmúak; gyümölcseikre nagy és puha húsállomány jellemző.

Mehlenbacher et al. (1991) nyolc ökogeográfiai csoportot alakítottak ki: Dzsungáriaialtáji, Közép-ázsiai, Iráno-kaukázusi, Európai, Észak-kínai, Tibeti, Északkelet-kínai és Keletkínai. Surányi (2011) Kosztina (1936, 1964) rendszerét átdolgozva mutat be egy új csoportosítást. Az Armeniaca vulgaris fajtáit a következő csoportokba sorolja:

- Közép-Ázsiai csoport: erős hajtásnövekedésü, késői virágzású fajták tartoznak ebbe a csoportba; a fajták május és szeptember között érnek; két alcsoportjuk van a fergániai és a szamarkandi; pl.: 'Kecs-psar'.

- Iráni-kaukázusi csoport: a fajták fáinak koronája szétterülő; az egyes fajták egymást követve érnek be két hónap alatt; pl.: 'Kései óriás'.

- Európai-amerikai csoport: az ide tartozó fajták növekedése középerős; három alcsoportját különítik el: édes magvú fajták pl. Magyar kajszi fajtakör, keserü magvú fajták pl. Borsi-féle kései rózsa, és vegyes származású fajták pl. 'Harcot'.

Más fajokból származó fajtákat három csoportba sorolja: Szibériai-mandzsu csoport; japáni és kelet-ázsiai csoport, valamint a nemzetséghibridek csoportja. Megkülönböztett továbbá nemesítésben eddig nem használt fajokat, melyeket két csoportba, az ázsiai és alpesi-balkáni csoportba sorolja.

A kajszi termesztésbe vonása nagyon régre nyúlik vissza, Kínában i.e. 3000 körül vonták termesztésbe, de nyugaton is kb. 2000 éve termesztik (Surányi, 1981). A kajszi elterjedésében jelentős szerepet töltött be a selyemút (Boulnois, 1972). Lösching és Passecker (1954) cit. Surányi (2011) a kajszi terjedésének három irányát írta le: északi: Kis-Ázsián át került a Balkánra; déli: Örményországon keresztül Szíria, Arábia, Görögország, Olaszország és ÉszakAfrika; középső: Közép-Duna-völgy, Németország és Ausztria felé. Magyarország területére valószínűleg egyrészt dél felől, a mediterránból, másrészt kelet felől a Volga menti területekről kerülhetett be a faj (Szalay, 2004). 
A török hódoltság ideje fontos korszaknak számít a magyar kajszitermesztés történetében, három jelentős termesztökörzet volt Magyarországon: Tolna, Kecskemét és Gönc. A török uralom megszünésével hanyatlásnak indult a kajszitermesztés, majd a 18. század második felében fejlődésnek indult újra, mert ekkor az Alföldön elkezdték használni a fajt a futóhomok megkötésére (Surányi, 2003).

\subsection{A kajszitermesztés nemzetközi és hazai helyzete, fajtahasználat}

2013-ban a világ összes kajszitermése 4,1 millió tonna volt, ebböl legnagyobb mennyiséget Ázsia termelte meg (2.463.864 millió t). Jelentős még Európa (886.617 t), valamint Afrika (651.588 t) kajszitermés-mennyisége. Amerika (93.053 t) és Ausztrália (15.953 t) részesedése minimális (FAO, 2013).

A kajszi rossz ökológiai adaptációs képessége korlátozza a fajták széles körü elterjedését. A termesztés főként mindenütt a helyi fajtákra korlátozott, a külföldi fajták honosítása és termesztésbe vonása nagyon nehézkes emiatt (Guerriero, 1982). Ebből adódóan a mediterrán és a mérsékelt égövi terület fajtahasználata különböző, míg a mediterránban rövid mélynyugalmú, alacsony hidegigényü, meleg- és napfényigényes fajták termeszthetők, addig a mérsékeltégövi területeken nagyobb hidegigényü, hoszabb mélynyugalmú, jobb fagyállóságú fajták terjedtek el. Vannak olyan kajszifajták, amelyeknek az átlagosnál jobb az ökológiai alkalmazkodó képességük, ilyen például a 'Bergeron’ (Mády és Szalay, 2003).

A világ vezető kajszitermesztő országa Törökország (Wani et al., 2015), 2013-ban 811.609 tonna kajszi termett itt (FAO, 2013). A termés 80-90\%-ából aszalványt készítenek, az erre legalakalmasabb fajtájuk a 'Hacihaliloglu'. Számos helyi fajtájuk van, úgymint a 'Turfanda' és a 'Cologlu' (Szalay, 2013).

Az Európai Unióban Olaszország a legnagyobb termelő, a betakarított termés mennyisége 2013-ban kb. 200.000 t volt (FAO, 2013). A két legjelentősebb termesztőkörzet Campania és Emilia-Romagna tartomány (Mádi és Szalay, 2003). Sok fajtájuk népi szelekció útján keletkezett, de intenzív nemesítési munka is folyik az országban (Conte et al., 2010). Elsősorban friss piacra értékesítenek, a megtermelt termés mennyiségének 38\%-át hasznosítja a feldolgozóipar, pürét és sürítményt készítenek belőle (Bettini, 2013a). Fő fajtájuk majdnem minden termesztő tájon a 'San Castrese', egész Olaszországban elterjedt továbbá: a 'Vitillo', a 'Portici' és a 'Palummella'. A kései érésűek közül fő fajta mindenütt a 'Pisana' (Szalay, 2013). 
Jelentős kajszitermesztő ország Franciaország és Spanyolország is, 2013-ban 133.646 t és 131.800 t kajszit szüreteltek (FAO, 2013). Franciaországban az ország dél-keleti részén termesztik a kajszit, míg Spanyolországban Murcia és Valencia tartományokban. A termőhely folyamatos csökkenése miatt Valenciában gyakorlatilag felszámolták a kajsziültetvényeket (FruitVeb, 2012). Franciaországban, a Rhone folyó völgyének felső részén a 'Bergeron' a fő fajta, Avignon környékén az 'Orangé de Provence', a 'Goldrich', a 'Modesto', valamint az 'Orange Red', míg Roussillonban a 'Rouge du Roussilon'. Spanyolországban, Murciában a fö fajta a 'Bulida' (Szalay, 2013). A sarka-vírus és más növény-egészségügyi problémák miatt jelentős mértékben vágják ki ezt a fajtát (FruitVeb, 2012). Korai fajtáik továbbá: a 'Mauricio’, a 'Valenciano', a 'Currot', a 'Palau', a 'Ginesta', és a 'Palabras', késői érésűek pedig a 'Tadeo' és a 'Pepito del Rubio' (Szalay, 2013).

Görögországban 84.100 t volt 2013-ban a termésmennyiség (FAO, 2013). Krétán, Thesszáliában és Peloponnész-félszigetén folyik jelentős kajszitermesztés. Vezető kajszifajták: 'Tirinthos', 'Aurora', 'Bebekou' és 'Diamantopoulou'. A megtermelt kajszi 50-60\%-ából befött készül, mindössze 20\% megy friss piaci célra, a fennmaradó részből pürét és sürítményt készítenek (Bettini, 2013b).

Hazánkban az éves termésmennyiség ingadozó, általában 10-45 ezer tonna között mozog (FruitVeb, 2013). A FAO (2013) kimutatása alapján Magyarországon 20.900 t termett kajsziból 2013-ban. A hosszú időn keresztüli magról történő szaporítás miatt jellegzetes fajtakörök alakultak ki, ilyen például a Magyar kajszi fajtakör, a Korai piros és a Kései rózsa fajtakör, különleges gyümölcsminőség jellemzi a Bíborkajszi, az Óriás, valamint a Mandulakajszi fajtakörök fajtáit (Mády és Szalay, 2003). A legelterjedtebb fajták a Magyar kajszi fajtakörhöz tartoznak ('Gönci magyar kajszi’ és 'Magyarkajszi C.235'). Ezen kívül elterjedt még a 'Ceglédi óriás', a 'Pannónia', a 'Ceglédi bíborkajszi' és a 'Mandulakajszi' (Szalay, 2013). A hazai fajtahasználatról elmondható, hogy jelenleg túlsúlyban vannak a magyar származású fajták, de ha az új telepítéseket nézzük (2008 óta 510 ha-on telepítettek kajszit), akkor megállapíthatjuk, hogy a külföldön nemesített fajták telepítési aránya jelentősebbé vált a hazaiaknál. Ennek valószínűleg az az oka, hogy az utóbbi években megváltoztak az áruértékkel szembeni követelmények, valamint az érési szezon meghosszabításának igénye felerősödött (FruitVeb, 2012). Magyarországon jelenleg 31 államilag elismert kajszifajta van nyilvántartva, ebből 10 külföldi eredetű, továbbá 1 tájfajta, 10 hivatalosan elismert leírással rendelkező kajszifajta, valamint 1 szaporításra egyedileg engedélyezett (NÉBIH, 2014). 


\subsection{Nemesítési trendek és nemesítő műhelyek}

Korábban a gyümölcsminőség javítása volt a legfontosabb nemesítési cél hazánkban és más országokban is egyaránt. Ennek következményeként nagyon sok olyan fajta került be a termesztésbe, amely betegségekre fogékony és faggyal szemben érzékeny volt. Ennek hatására napjainkra a nemesítők legfontosabb célkitűzése az ellenállóság fokozása lett (Szalay, 2013). Pedryc és Hermán (2011) a legfontosabb nemesítési célkitűzések közé sorolja: a virágzási időszak módosítását, az érési időszak széthúzását, a biotikus rezisztencia kialakítását, az abiotikus rezisztencia fokozását, valamint a gyümölcsminőség javítását.

Kanadában a Harrow Kutató Intézetben folyt jelentős kajszinemesítés. Főbb célkitüzésük volt a késői virágzású, jó fagytürő, rendszeres terméshozású fajták nemesítése. Ebben a kutatóban nemesített fajták többek között a 'Harcot', 'Harogem', 'Hargrand', 'Harlayne', 'Harglow', 'Laycot', 'Harval' (Layne, 1996), 'AC Harojoy', 'AC Haroblush', 'AC Harostar' (Layne és Hunter, 2003a,b,c). Törökországban Malatya tartományba az Inonu Egyetemen folyik nemesítő munka. Céljuk korai és késői érésü fajták nemesítése; a szárítási hatékonyság növelése és a sarka vírussal szemben rezisztens fajták előállítása. Nemesített fajtáik többek között a 'Levent' (Asma, 2007) és a 'Bilbay' (Asma, 2012). Az ausztrál nemesítők fő célja aszalásra alkalmas kajszifajták előállítása. Saját nemesítésű fajtáik a 'Rivergem', 'Riverbrite', 'River Ruby’ (Graetz, 2006). Csehországban, Lednice-ben az intenzív nemesítő munka következtében jó fagytürő kajszifajtákat: 'Lejuna', 'Leskora', 'Lebela', 'Ledana', 'Leala', 'Lerosa' és sarka vírus rezisztens fajtákat: 'Lemeda', 'Marlen', 'Palava', 'Svatava', 'Minaret' nemesítettek (Krška et al., 2005). Franciaországban a szüreti szezon széthúzása a legfontosabb cél, Marie France Bois nemesítő hozta létre az összes 'Bergeron' után érő fajtát ('Farbaly', 'Farely', 'Farhial', 'Fardo' stb), amellyel a szüreti szezont jelentősen meg tudták hosszabítani (Darnaud, 2013). Spanyolországban két tartományban is folyik nemesítés. Murcia-ban nemesítették például a 'Rojo Pasion' (Egea et al., 2004), Valencia-ban pedig a 'Moixent' nevü sarka vírussal szemben rezisztens kajszifajtát (Martínez-Calvo et al., 2012). Olaszországban több helyen is folyik intenzív nemesítő munka, olasz nemesítésű fajták például a 'Mandorlon' és a 'Tardif de Bordaneil'. Román nemesítésből származó fajták többek között a 'Comandor', a 'Sirena', az 'Olimp', a 'Favorit' valamint a 'Sulmona' (Mády és Szalay, 2003).

Hazánkban a Budapesti Corvinus Egyetem Genetika és Növénynemesítési Tanszékén, valamint a NAIK Ceglédi Kutató Állomásán folyik kajszinemesítés. A Genetika Tanszéken nemesített fajták többek között a 'Harmat', a 'Korai Zamatos', a 'Corred', a 'Corfirm', a ‘Corlate’ (Pedryc és Hermán, 2012). A Ceglédi Kutató legújabb fajtái a 'Ceglédi napsugár', a 
'Nyujtó Ferenc emléke' (Erdős et al., 2010), a 'Ceglédi szilárd' és a 'Ceglédi gömbölyü' $(\mathrm{MgSZH}, 2011)$.

\subsection{A virágrügyek képződése}

A virágrügyek kialakulása hosszú folyamat, amely a hajtások nóduszain a nyár második felében kezdődik, és a következő év tavaszán a virágok kinyílásával zárul. Ez a folyamat három nagy szakaszra osztható, az előnyugalom, a mélynyugalom és a kényszernyugalom időszakára.

A fejlődés kezdetén minden virágrügynek van egy vegetatív fázisa. A virágrügy előnyugalmi szakasza az indukcióval kezdődik. Ez hormonálisan programozott folyamat, ekkor még nem történik változás a rügyek szövettani szerkezetében, csak biokémiai változások jelzik, hogy megkezdődött a virágrügy-differenciálódás. A következő szakasz az iniciálódás, amikor az addig vegetatív tenyészőcsúcs szövettanilag is generatívvá válik. Ennek első látható jele a csúcsmerisztéma ellaposodása. Ezután kialakul a „kocka” stádium, majd kívülről befelé haladva kialakulnak a virágszervek kezdeményei, a következő sorrendben: csészelevelek, sziromlevelek, porzók és termő (Szalay, 2003).

A környezeti tényezők (hőmérséklet, napsugárzás, csapadék mennyiség), az abiotikus stressztényezők előfordulása a differenciálódás előtt és után, valamint a termesztéstechnológia (metszés ideje és típusa, művelési rendszer, trágyázás, öntözés, vegyszeres kezelések) hatással vannak a virágrügyek képződésére (Xiloyannis, 1999; Lamp, 2001; Neri, 2010). Negatív hatással bír például vegetációs időszakban a korona kedvezőtlen megvilágítottsága (Nuzzo, 1999). A korona árnyékos oldalán kevesebb a vessző, s a vesszőkön kevesebb virágrügy is képződik, amely veszélyezteti a jövő évi rügyek és virágok minőségét (Alburquerque, 2004; Julian et al., 2010). A kedvező megvilágítottságú koronarészek aránya intenzív koronaformák esetén, optimális sor- és tőtávolság mellett relatíve nagyobb (Gonda, 2014).

A virágrügyképződés kezdete a kajszifákon július végén, illetve augusztus hónapban, rövidülő nappalhosszok idejére tehető (Szalay, 2003), s a virágkezdemény kialakulása október végére fejeződik be (Bubán, 2003). A virágrügyképződés kezdete alapján a magyar fajták sorrendje: 'Korai kajszi', 'Ceglédi bíborkajszi', 'Magyar kajszi C.235', 'Ceglédi óriás', 'Ceglédi hajnalpír', 'Kécskei rózsa'. A virágképzés kezdete és tartama között negatív összefüggés áll fenn. Későn kezdődő differenciálódáskor gyorsabb a virágrügyek fejlődési üteme, s a korai időponthoz lassabb fejlődés is társul (Surányi, 2011). 
Németh (2012) a virágrügyfejlődés fenológiai folyamatát az előnyugalom idején öt kajszifajtánál ('Ceglédi bíborajszi’, 'Harcot', 'Gönci magyar kajszi', 'Bergeron', 'Rózsakajszi C.1406’), két különböző termörész típuson, három egymás utáni évjáratban vizsgálta fénymikroszkóp használatával. Öt fejlődési szakaszt különített el:

0. stádium: a hajtástenyészőkúp vegetatív állapotban van a virágrügyekben,

1. stádium: hajtástenyészőkúp ellaposodik, generatív állapotba kerül,

2. stádium: csészelevél-kezdemények kialakulása a virágrügyben,

3. stádium: sziromlevél-kezdemények kialakulása a virágrügyben,

4. stádium: porzók kialakulása a virágrügyben,

5. stádium: termőlevél kialakulásának kezdete a virágrügyben.

Jelentős különbségeket talált a virágrügyfejlődés ütemében az előnyugalom során a fajták, a termőrésztípusok, valamint az évjáratok között. Fajtától és évjárattól függetlenül a nyársakon előbb kezdődött el a fejlődés, illetve korábban is fejeződött be, mint a hosszú vesszőkön.

A növényi hormonok a virágindukció fontos regulátorai (Bubán, 2003). Luckwill (1970) szerint a virágrügyképződést gibberellin/citokinin arányhoz kötött. A gyökerekben szintetizált citokininek elősegíthetik a virágrügyek képződését (Dencker és Hansen, 1994). A kajszifákon a gibberellines kezelés gátolja a virágrügyképződést (Southwick és Fritts, 1995; Southwick és Glozer (2000). Bubán (2003) Schmidt et al. (1975) munkájára hivatkozva leírja, hogy etiléngenerátorokkal fokozható a virágrügyképződés.

\subsection{A kajszi téli nyugalmi állapota}

A kajszi mélynyugalmi időszaka ősszel, a természetes lombhullással kezdődik meg, rügyei a lombhullás után fokozatosan kerülnek nyugalmi állapotba. A hajtás- és virágrügyekben jelentős változások zajlanak le ebben az időszakban, melyek befejeződésével megindul a mikrosporogenezis folyamata (Brown és Kotob, 1957).

A téli nyugalmi állapot két szakaszból áll, a mélynyugalomból és a kényszernyugalomból (Dennis, 1994; Faust et al., 1997; Tromp, 2005). Míg az előnyugalom a növényi részek korrelációján alapul, a mélynyugalom a növényi struktúrán belül szabályozott nyugalom. A kényszernyugalmat a környezeti hatások szabályozák (Lang, 1987). A nyugalmi állapot szakaszai között az átmenet fokozatosan történik (Szalai, 1994; Faust et al., 1997), a mélynyugalomba való átmenet belsőleg szabályozott (Tromp, 2005). 
Surányi (2011) szerint a virágrügyek növekedésének lelassulása jelzi a mélynyugalom kezdetét, ami fajtánként és évjáratonként eltérő. A mélynyugalom segíti a fa szerveinek áttelelését anélkül, hogy károsodnának. A kajszi is ebben a szakaszban képes a legnagyobb lehüléseket elviselni, virágrügyei akkor a legfagyállóbbak, ha mélynyugalomban vannak (Guerriero, 1982).

A rügyek mélynyugalmának lefolyását a következő biológiai tényezők befolyásolják: a hormonok egyensúlya, a rügy vízállapota, a sejtmembránok szerkezete és a rügy anyagcseréje (Faust et al., 1997). Dennis (1994) szerint a mélynyugalmat a növekedést serkentő és növekedést gátló anyagok egyensúlya jellemzi, ez az állapot mindaddig fent marad, míg a növekedést serkentő anyagok irányába el nem tolódik az egyensúly. Seeley (1990) szerint az auxin és a citokinin a téli nyugalmi időszakban nincs jelen a növények szervezetében, a giberrellin szeptembertől kezd felhalmozódni, az abszcizinsav egész évben jelen van, a mélynyugalom kezdetéig van belöle a legtöbb.

Egy bizonyos mennyiségü hideghatás szükséges ahhoz, hogy feloldódjon a mélynyugalom. Ez a hidegmennyiség genetikailag meghatározott, fajonként és fajtánként eltérő. A hidegigény továbbá függ a földrajzi helytől, a klímától és az alanytól is (Guerriero et al., 2006). A kajszifajták nagyon eltérő, 300 és 1000 óra közötti hidegigénnyel rendelkeznek (Westwood, 1993), de előállítottak már 1300 óra feletti hidegigényü hibridet is (Bailey et al., 1981). A Magyarországon termesztett kajszifajták virágrügyeinek 900-1000 óra 0 és $+7{ }^{\circ} \mathrm{C}$ közötti hőmérséklet szükséges ahhoz, hogy megszünjön a mélynyugalmuk (Surányi és Molnár, 1981).

Hazánkban a termesztett fajtáknál körülbelül december végén, január elején megszünik a mélynyugalom, majd megindul a januári felmelegedések hatására a rügyek fejlődése (Surányi és Molnár, 1981). A mélynyugalom idején, a portokokon belüli szövet úgynevezett archespórium állapotban van, a mélynyugalom végét a füzér állapot jelzi, ezzel párhuzamosan a termő is növekedni kezd (Elmanov, 1961 cit. Szalay, 2001). A termő hossza egészen a virágzásig növekszik (Molnár, 1992). A füzér állapotot a pollenanyasejt állapot követi, majd a tetrád állapot, ami a pollenanyasejtek meiotikus osztódásával alakul ki. A tetrádok függetlenné váló sejtjei a mikrospórák, ezekből alakulnak ki a fajtára jellemző pollenek (Shivanna és Johri, 1985).

A téli nyugalmi időszak során a kajszi genotípusok virágrügyfejlődésének üteme jól tanulmányozható a portokokon belül zajló fejlődési folyamat, vagyis a mikrosporogenézis vizsgálatával. Mint minden fenológiai folyamat, ez is alapvetően genetikailag meghatározott, 
fenotípusos kifejeződését azonban a környezeti tényezők, ezek közül is elsősorban a hömérséklet nagymértékben befolyásolják (Szalay, 2001).

A mediterrán térség termőhelyein részletes vizsgálatok készültek a legfontosabb termesztett kajszifajták mikrosporogenéziséről (Scalabrelli et al., 1991; Viti és Monteleone 1991; Bartolini és Viti 1999, Bartolini et al., 2006a, 2006b; Julian et al., 2009, 2011; Andreini et al., 2012). Magyarországon Nyujtó és Banainé (1975), valamint Banainé (1981) végezték az első ilyen irányú kutatásokat, és magyar nemesítésű fajtákat vizsgáltak. Később a magyar fajták mellett külföldi fajták is vizsgálat alá kerültek magyarországi termőhelyeken (Szalay 2001; Szalay et al., 2004; Szalay et al., 2006a, 2006b; Szalay et al., 1999; Németh et al., 2009; Szalay és Németh 2010).

Az eddigi kutatási eredményeket összegezve megállapítható, hogy nagy a változatosság a kajszi genotípusok között a mikrosporogenézis ütemét tekintve, ezen kívül nagy különbségek vannak a termőhelyek és évjáratok között is. Magyarországon a termésbiztonság szempontjából a lassú téli virágrügyfejlődésű, hosszú mélynyugalmú kajszifajtáknak nagy jelentőségük van (Szalay 2001, 2008). Nyujtó és Banainé (1975) magyar kajszifajták pollenfejlődését vizsgálták, jelentős különbségeket találtak a fajták és az évjáratok között. Vizsgálataik alapján a 'Ceglédi bíborkajszi' fajta mélynyugalma volt a legrövidebb, ezt követte a 'Magyar kajszi C.235' fajta, míg a jó fagytürőképességü 'Kecskeméti rózsa C778' fejlődése volt a leglassúbb. Szalay (2001) magyar és külföldi kajszifajták mikrosporogenezisét vizsgálta. Leglassúbb virágrügyfejlődésűnek a 'Zard' fajtát találta, viszonylag lassú rügyfejlődésű a 'Harlayne', 'Harglow', ‘Comandor' és ‘Callatis', míg a leggyorsabb virágrügy-fejlődésű a ‘Cafona’ fajta volt.

A hosszabb mélynyugalmú fajtákat általában nagyobb fagy- és télállóság jellemzi, mint a rövidebb mélynyugalmú fajtákat (Kostina, 1964). Az elhúzódó archespórium stádium a fagytürés szempontjából előnyös. Az európai és iráni-kaukázusi kajszifajták rövidebb, míg a közép-ázsiai fajták rügyei hosszabb ideig maradnak archespórium stádiumban (Surányi, 2011).

A fagytürés és az endogén nyugalom nem tekinthető azonosnak. Amíg az endogén nyugalom a növekedés számára kedvezőtlen egyensúlyra (alacsony citokinin- és gibberellinszint, nagy abszcizinsavartalom) vezethető vissza, a fagytürésnek ultrastruktúrális és fiziológiai (nagy szénhidráttartalom, kis víztartalom) okai vannak. A legtöbb gyümölcsfa endogén nyugalma március végére megszünik, a fagyérzékeny szervek aktív anyagcserét folytatnak, $\mathrm{s}$ ha tavaszi fagy éri őket, jelentősen károsodhatnak (Pethő, 1996). 


\subsection{A virágrügyek fagytürése}

Magyarország a kajszi gazdaságos termeszthetőségének északi határán van, ezért a fagy- és télállóság a termésbiztonság szempontjából a fajták meghatározó tulajdonsága (Pénzes és Szalay, 2003). A termésmennyiség évenkénti nagymértékü ingadozását a téli és kora tavaszi fagykárok okozzák. Míg a fagykároktól mentes években (pl. 2011) közel 40 ezer tonna kajszi terem Magyarországon, a fagykárokkal terhelt években (pl. 2012) csak 12 ezer tonna (FruitVeB, 2013).

A mérsékelt égövi lombhullató fák áttelelő szerveinek fagyállósága a téli nyugalmi időszak során folyamatosan változik, fokozatosan alakul ki, majd fokozatosan szünik meg (Proebsting, 1963; Smith et al., 1994; Lindén, 2002). A növényeknek az alacsony hőmérsékleti stressz kivédéséhez szükségük van egy hosszabb ideig tartó, alacsony hőmérsékletű növekedési időszakra, az edződésre. Az edződés a struktúrák és a funkciók változása, amely csökkenti a növényt ért károkat. Természetes körülmények között hazánkban az edződés ősszel történik, a rövidülő nappalhossz és a hömérséklet fokozatos csökkenése hatására (Hoffmann, 2011). A mérsékelt égövi gyümölcstermő fáknál a tél első felében lejátszódó edződésnek két szakasza különböztethető meg (Tromp, 2005).

A fagytürés alakulását alapvetően a növény genetikailag öröklött tulajdonságai határozzák meg, ezért a fajták között jelentős különbségek vannak. A genetikailag meghatározott fagytürő képesség fenotípusos kifejeződését, a tényleges fagyállóságot a környezeti tényezők nagymértékben befolyásolják, ezért egy adott fajta fagyállóságának alakulása eltérő a különböző évjáratokban és termőhelyeken (Pénzes és Szalay, 2003).

Az áttelelő szervek fagytürését közvetett és közvetlen módszerekkel vizsgálhatjuk. A közvetett módszerek közé tartozik a kálium exozmózis vizsgálata, amely a fajták összehasonlítására alkalmas. Az eljárás azon alapszik, hogy a fagykárt szenvedett szövetekből a kálium-ionok ozmózis útján könnyen kijutnak (Werner et al., 1993). A differenciál termál analízissel becsülni tudjuk a fagyállóság mértékét (Proebsting és Sakai, 1979; Aschworth et al., 1983; Gu, 1999, Flinn et al., 1999; Tromp, 2005; Ferguson et al., 2011; Salazar-Gutiérrez et al., 2014). A vizsgálati módszer lényege, hogy folyamatos lehütés során a növényi részekben és a környezetükben mérik a hőmérsékleteket. A különböző helyeken képződő jég hőt szabadít fel, amelynek következtében a szövetek és a levegö hőmérséklete között eltérések, úgynevezett exotermek alakulnak ki. A legalacsonyabb hőmérsékleten keletkezett exoterm a sejt pusztulását jelzi (Faust, 1989). 
Pontosabb eredményeket a közvetlen módszerek szolgáltatnak. Erősebb lehülések után felvételezhetjük a természetes fagykárokat (Faust, 1989; Szabó et al., 1995). Természetes lehülés után a fagykár mértékét a különböző szervek felvágásával tudjuk felmérni. A fagykárt a felvágott szövetek elbarnulása jelzi. A módszer előnye, hogy olcsó, nagy mintaszámot tudunk könnyen megvizsgálni. Hátránya, hogy csak természetes lehülés során tudunk vizsgálódni, ezért csak az adott alacsony hőmérséklet okozta kár mértékéről kapunk információt, a fagytürés változásáról nem (Faust, 1989).

A szabadföldi vizsgálatok során Soltész (1997) megállapította, hogy a gyümölcsfajok közül a kajszi a legkevésbé fagytürők közé tartozik. A kutatók a kajszifajták fagytürő képessége között jelentős különbségeket találtak (Pedryc és Szabó, 1995; Szabó és Nyéki, 1988; Szalay, 2001). Szabó és Nyéki (1988) a kajszifajtákat három csoportba sorolták a rügyvizsgálatok alapján: (1) fagyérzékenyek pl. 'Ceglédi bíborkajszi’; (2) közepesen fagyérzékenyek pl. 'Ceglédi óriás'; (3) kevésbé fagyérzékenyek pl. 'Bergeron'. Drén et al. (2005) két termőhelyen (Sóskút és Boldogkőváralja), különböző kajszifajták természetes fagykárának mértékét vizsgálták szabadföldi felvételezéssel. Sóskúton 2005. február 10 -én $-18,8{ }^{\circ} \mathrm{C}$ hatására a 'Veecot' fajta virágrügyei 30\%-ban károsodtak, míg a 'Hargrand' fajta fagykárának mértéke 8\% volt. Ugyanebben az időpontban Boldogkőváralján $-13,5{ }^{\circ} \mathrm{C}$ hatására a 'Bayoto' fajtánál mértek jelentős károsodást $(35 \%)$.

A fagyállóság változásának folyamatát mesterséges fagyasztásos vizsgálatokkal tudjuk pontosan meghatározni (Proebsting és Mills, 1978; Westwood, 1993; Layne et al, 1995; Pedryc et al., 1999; Miranda et al., 2005; Szalay, 2001; Szalay et al., 2010). A módszer lényege, hogy mesterséges hideghatásnak tesszük ki a növényi részeket, majd felmérjük a károsodásuk mértékét (Faust, 1989). Több kísérleti hőmérsékletet alkalmazva, a hőmérséklet és a fagykár összefüggését szigmoid görbével tudjuk leírni, amelynek a 20 és a 80\%-os fagykár közé eső szakasza lineárisnak tekinthető ( $\mathrm{Gu}, 1999)$. A szigmoid görbe jellemző pontjai és a lineáris szakasz dőlésszöge jól jellemzik az adott időpontban a genotípus adott szervének fagyállóságát. A fagyállóság jellemzésére leggyakrabban a szigmoid görbe 50\%-os értékéhez tartozó kvantilisét használják. Ezt Proebsting és Mills (1966) vezették be, és $T_{50}$ értéknek nevezték, majd Quamme (1974) ezt $\mathrm{LT}_{50}$ értéknek nevezte el. $\mathrm{Az}_{\mathrm{LT}} \mathrm{T}_{50}$ érték tehát az a hőmérséklet, ami az adott időpontban 50\%-os fagykárt okoz. A mesterséges fagyasztással kapott $\mathrm{LT}_{50}$ értékek pontossága függ a lehűlés sebességétől és a mintaszámtól. A kísérlet során a természetes hideghatást kell modellezni, és nagy mintaszámmal dolgozni, hogy pontos eredményeket kapjunk (Kang et al., 1998; Pedryc et al., 1999). Bittenbender és Howel (1974) a Sperman-Kärber módszer segítségével a mért adatok alapján egy matematikai képletet készített, amellyel az $\mathrm{LT}_{50}$ értéket ki 
tudta számolni. Az $\mathrm{LT}_{50}$ értéket különféle matematikai modellel, például lineáris regresszióval (Burr et al., 1993); nem lineáris regresszióval (Zhu és Liu, 1987) és logaritmus modellel (Lindén et al., 1996) becsülték.

Hewett (1976) Új-Zélandon két kajszifajta virágrügyeinek fagytürését vizsgálta három egymás utáni évben (1967-1969). Megállapította, hogy június végén fokozatosan növekedett, majd ezután folyamatosan csökkent a rügyek fagytürésének mértéke. A három év vizsgálati eredményei alapján a 'Moorpark' fajtánál a legnagyobb fagyállóságot jelző $\mathrm{LT}_{50}$ érték -12; -13 ${ }^{\circ} \mathrm{C}$, a 'Roxburg Red' fajtánál pedig $-15^{\circ} \mathrm{C}$ volt.

Pedryc et al. (1999) három különböző hőfokon öt kajszifajta rügyeinek fagykárosodását vizsgálták. Megállapították, hogy az adott fajták rügyeinek károsodásában már $1{ }^{\circ} \mathrm{C}$ különbség is jelentős eltéréseket okoz. A 'Gönci magyar kajszi' esetében $-9{ }^{\circ} \mathrm{C}$-on a rügyek $23 \%$-a fagyott el, -10 ${ }^{\circ}$ C-on pedig 75\%-ban károsodtak. Szalay (2001) 1998-ban Szigetcsépen 20 kajszifajta fagytürését vizsgálta. Január 1-én voltak a legfagytürőbbek a fajták, ekkor a fagytürési középértékük -20,5 és $-24{ }^{\circ} \mathrm{C}$ között volt. Kiemelkedő fagytürési értékeket a 'Zard' esetében mért. Szalay (2003) az 1998-99-es télen Szigetcsépen, néhány fajtán végzett vizsgálata alapján kimutatta, hogy az őszi lombhulláskor csak $3,5{ }^{\circ} \mathrm{C}$ különbség volt a fajták virágrügyeinek fagytürési középértékei között, ami januárban $5{ }^{\circ} \mathrm{C}$-ra emelkedett, majd a virágzás előtti hetekben $2,5^{\circ} \mathrm{C}$-ra csökkent ismét. A virágrügyek fagyállósága januártól folyamatosan csökkent, a csökkenés üteme a fajtától és az év hőmérsékleti viszonyaitól függött. Drén et al. (2005) mesterséges fagyasztással különböző fajták fagytürését vizsgálták decembertől márciusig. Decemberben $-19{ }^{\circ} \mathrm{C}$-on a rügyek még alig károsodtak, $-20{ }^{\circ} \mathrm{C}$-on a 'Toyiba' és 'Toyuda' már $80 \%$ felett fagyott el, a 'Magyar kajszi C.235' fajta károsodásának mértéke pedig 2,2\% volt.

A kajszi áttelelő szervei közül a virágrügyek a legfagyérzékenyebbek (Smeeton, 1964; Stushnoff, 1972; Pénzes és Szalay, 2003; Gunes, 2006; Bartolini et al., 2006c). A kajszi hajtásrügyeinek fagyállósága a virágrügyétől eltérően változik. Egy vizsgálat során a tél első felében a virágrügyek 1-2 ${ }^{\circ} \mathrm{C}-\mathrm{kal}$ fagyállóbbak voltak a hajtásrügyeknél, decembertől a hajtásrügyek váltak néhány fokkal fagytürőbbé. A vesszők fás részei 5-6 ${ }^{\circ} \mathrm{C}$-kal alacsonyabb hőmérsékleten károsodtak. (Szalay, 2003). Layne és Gadsby (1995) 27 kajszifajta virágrügyeinek és a fiatal fás részek xilémjének fagytürését hasonlították össze. Eredményeikből kitünik, hogy a fás részek 6-7 ${ }^{\circ} \mathrm{C}-\mathrm{kal}$ alacsonyabb hőmérsékleten károsodtak, mint a virágrügyek. 


\subsection{A kajszi virágainak fagyállósága}

A kajszi virágzási ideje a többi gyümölcsfajhoz viszonyítva korán kezdődik, a mogyorót és a mandulát követően virágzik. Hazánkban a virágzás kezdetének időpontja február vége és április második fele között várható, az évjárattól és a termőhelytől függően. A fajták virágzási idejét befolyásolják a klimatikus tényezők, viszont a fajták relatív virágzási ideje stabil (Szabó et al., 2002, 2003; Surányi, 2011).

A kajszi virágzását a kutatók különböző fenofázisokra osztották fel (Brózik, 1960; Nyujtó, 1980; Surányi és Molnár, 1981; Westwood, 1993; Nyéki 2003). Nyujtó (1980) a virágnyílás hat fenofázisát különböztette meg: (1) pirosbimbós állapot; (2) fehérbimbós állapot; (3) a virágzás kezdete; (4) fővirágzás; (5) a sziromhullás kezdete; (6) a sziromhullás vége. Westwood (1993) a virágzás öt fenofázisát különítette el: (1) zárt bimbós állapot; (2) fehérbimbós állapot; (3) virágzás kezdete; (4) fővirágzás; (5) virágzás vége.

A kajszi termésbiztonságát elsősorban a tavaszi fagyok veszélyeztetik (Szalay, 2003; Guerriero et al., 2006). Eurázsia és Észak-Amerika mérsékelt övi termőtájain márciustól május közepéig lehet számítani fagyra (Surányi, 2011). Több kutató vizsgálta a különböző fenofázisokban a kajszi reproduktív szerveinek fagyállóságát. A vizsgálati eredmények azt mutatták, hogy a fenológiai folyamatok előrehaladtával a fagytürő képesség folyamatosan csökkent (Hewett, 1976; Proebsting és Mills, 1978; Nyujtó és Surányi, 1981; Guerriero, 1982).

Hewett (1976) Új-Zélandon a 'Roxburg Red' esetében vizsgálta az LT $_{50}$ értékek alakulását a virágzás alatt. Eredményei alapján elmondható, hogy fővirágzás idején a fajta érzékenyebb volt a hidegre, mint fehérbimbós állapotban. Zayan (1981) eredményei szerint pirosbimbós állapotban $-5 ;-8{ }^{\circ} \mathrm{C}$ okozott $50 \%$-os fagykárt a virágoknál, ezután a virágszervek egyre érzékenyebbé váltak, és teljes nyílásban $-3{ }^{\circ} \mathrm{C}$ is jelentős károsodást okozott. Szalay (2003) magyar származású kajszifajták generatív szerveinek fagyállóságát vizsgálta mesterséges fagyasztással. Eredményei szerint pirosbimbós állapotban $-4 ;-7^{\circ} \mathrm{C}$ alatti hőmérsékletek voltak károsak, ugyanakkor a gyümölcskezdemények $-2{ }^{\circ} \mathrm{C}$ alatt jelentős mértékben károsodtak.

\subsection{A fagykár kialakulásának élettani és genetikai háttere}

A fagynak a károsító hatása egyfelől a sejtekből történő vízelvonáson alapszik (Mollisch, 1926). Az alacsony hömérséklet károsító hatása abból is adódhat, hogy a szövetek víztartalma megfagy. A fagytürő növényeknél, ha fokozatos a lehülés, a sejtközötti járatokban levő víz fagy meg először. Az extracelluláris jégképződés során a sejt fokozatosan dehidratálódik, a sejtnedv 
bekoncentrálódik, a plazma zsugorodik, a térfogatváltozás károsítja a membránokat. Fagyérzékeny növényeknél, vagy gyors lehülés hatására a jégkristályok a sejtben képződnek. A jégkristályok roncsolják a membránokat, s a sejt elhal (Pethő, 1996). Az egyes baktériumok, mint például a Pseudomonas syringae és az Erwinia herbicola felgyorsítják a jégkritályok képződését (Lindow et al., 1982). Ezeket a baktériumokat jégaktív baktériumoknak is szokták nevezni. Ha a fák szöveteiben nagy mennyiségben megtalálhatók, akkor lecsökken a fagyállóság (Faust, 1989).

A faggyal szembeni ellenállóság kialakulása számos fizikai és biokémiai folyamat eredménye, megváltozik a membránösszetétel, AFP (Anti Freeze Protein) fehérjék indukálódnak, stb., ami lehetővé teszi, hogy a növények alacsony hőmérsékleten is életben maradjanak (Janda et al., 2014). Alacsony hőmérséklet hatására a gének aktivitása megváltozik, új mRNS-ek és fehérjék jönnek létre a sejtekben. A hidegstressz során a növényekben úgynevezett AFP fehérjék termelődnek. Ezek a fehérjék gátolják a jégkristályok növekedését, és befolyásolják a növekvő jégkristályok alakját is (Taiz és Zeiger, 2010).

A faggyal szembeni ellenállóságot számos, sokszor fajspecifikus faktor határozza meg, nagyban nehezítve ezzel az ellenállóság mechanizmusának pontos feltérképezését. Ennek következtében a robbanásszerủen fejlödő molekuláris módszerek alkalmazása különösen nagy jelentőséggel bír a fagyellenállóság kutatásában (Gusta és Wisniewski, 2013). Ezidáig számos gént, valamint fehérjét sikerült azonosítani, melyek összefüggésbe hozhatók a növények ellenállóképességével. Arabidopsis növények kutatása során kimutatatták, hogy az un. CBF (Crepeat Binding Factor) transzkripciós faktornak döntő szerepe van az alacsony hőmérsékleti stressztolerancia szabályozásában (Gilmour et al., 1998; Wisniewski et al., 2011). Hideg hatására a $C B F$ útvonalon keresztül számos gén expressziója indukálódhat, melyeket a szakirodalom gyüjtőnéven COR (Cold Regulated Genes) génekként emleget.

Csonthéjas gyümölcsfajok esetében is történtek már vizsgálatok az egyes COR gének szerepének tisztázása érdekében. Mousavi et al. (2014) mandula fagyasztásos vizsgálata során a portokban a $P d P r o D H$ és $P d T P S$ gének, míg a termőben a $P d P G K$, PdRab7 és $P d S h m t 1$ gének hideghatásra történő fokozott expresszióját figyelte meg. Shin et al. (2014) különböző fagyellenállósággal rendelkező $P$. persica fajtákat mesterséges körülmények közt szakaszos meleghatásnak tett ki, ezzel előidézve a nyugalmi állapot idő előtti elhagyását. Vizsgálataik szerint a változó ellenállóképességgel pozitív arányban változott a $P p D h n 1$ gén által kódolt dehidrin fehérje akkumulációja. Gyengébb, de szintén pozitív korrelácó volt megfigyelhető a $\beta$ amiláz, valamint a PpDhn2 és $P p D h n 3$ gének esetében. 


\subsection{A kajszi táplálkozásbiológiai jelentősége és felhasználása}

Magyarországon a kajszi igazi hungarikum gyümölcsfajnak számít (Pénzes és Szalay, 2003). Értékes beltartalmi összetevőinek, élelmirost-tartalmának, ásványianyag-tartalmának, színanyagainak, antioxidáns hatóanyagainak köszönhetően friss és feldolgozott formában egyaránt kiemelt szerepet játszik az egészségmegőrző táplálkozásban (Németh et al., 2011a).

Gyümölcse szacharidokat, szerves savakat és ásványi elemeket (vas, bór és kálium), valamint vitaminokat, mint például $\mathrm{A}, \mathrm{B}$ és C-vitamin és polifenolokat tartalmaz (GarciaViguera et al., 1994; Pederson et al., 2000). Értékes gyümölcse miatt meglehetősen széles körben használják a népi gyógyászatban. Csökkenti az allergia és a vérszegénység kockázatát, segít a fáradékonyság, a stressz, az asztma és az álmatlanság ellen, növeli a zsírok lebontását, ezáltal csökkenti a vér kóros koleszterinszintjét (Garcia-Viguera et al., 1997; Record et al., 2001). A kajszi fontos beltartalmi értékeit az 1. és 2. táblázat tartalmazza.

1. táblázat: A kajszi beltartalmi értékei (Biró-Lindner, 1999)

\begin{tabular}{ccccccccc}
\hline & \multicolumn{2}{c}{ Energia } & Fehérje & Sav & Szénhidrát & Víz & Hamu & Nyers rost \\
\cline { 2 - 9 } & kJ & $(\mathrm{kcal})$ & & \multicolumn{4}{c}{$\mathrm{g} / 100 \mathrm{~g}$} \\
Kajszi & 202 & $(48)$ & 0,9 & 0,6 & 10,2 & 86,8 & 0,7 & 0,8 \\
\hline
\end{tabular}


2. táblázat: A kajszigyümölcs beltartalmi értékei (Souci et al., 1989)

\begin{tabular}{lcc}
\hline \multicolumn{1}{c}{ Alkotórész } & Mértékegység & Jellemzó érték \\
\hline Energia & $\mathrm{kJ}$ & 197 \\
& $\mathrm{kcal}$ & 47 \\
Víz & $\%$ & 85,3 \\
Fehérje & $\%$ & 0,9 \\
Szénhidrát & $\%$ & 10 \\
Szacharóz & $\%$ & 5,1 \\
Glükóz & $\%$ & 1,7 \\
Fruktóz & $\%$ & 0,87 \\
Összes sav & $\%$ & 1,4 \\
Almasav & $\%$ & 1 \\
Citromsav & $\%$ & 0,4 \\
Élelmi rost & $\%$ & 1,9 \\
Pektin & $\%$ & 0,8 \\
Ásványi anyagok & $\%$ & 0,66 \\
Borostyánkősav & $\%$ & 0,07 \\
Karotin & $\mathrm{mg} / 100 \mathrm{~g}$ & 2 \\
C-vitamin & $\mathrm{mg} / 100 \mathrm{~g}$ & 9,4 \\
B1-vitamin & $\mathrm{mg} / 100 \mathrm{~g}$ & 0,03 \\
B2-vitamin & $\mathrm{mg} / 100 \mathrm{~g}$ & 0,04 \\
Kálium & $\mathrm{mg} / 100 \mathrm{~g}$ & 278 \\
Kalcium & $\mathrm{mg} / 100 \mathrm{~g}$ & 16 \\
Vas & $\mathrm{mg} / 100 \mathrm{~g}$ & 0,63 \\
Foszfor & $\mathrm{mg} / 100 \mathrm{~g}$ & 21 \\
Nátrium & $\mathrm{mg} / 100 \mathrm{~g}$ & 2 \\
Magnézium & $\mathrm{mg} / 100 \mathrm{~g}$ & 9,2 \\
Bór & $\mathrm{mg} / 100 \mathrm{~g}$ & 0,47 \\
Réz & $\mathrm{mg} / 100 \mathrm{~g}$ & 0,14 \\
Cink & $\mathrm{mg} / 100 \mathrm{~g}$ & 0,7 \\
\hline & &
\end{tabular}

A kajszi szüreti szezonja rövid, frissen csak rövid ideig tudjuk fogyasztani, de számos termék készíthető belőle, ami lehetővé teszi az egész éves fogyasztását. A feldolgozott termékek közül a lekvár és a dzsem a legjelentősebb, a befött és ivólé készítésnek kisebb a jelentősége. Ezen kívül fontos termékünk a hungarikum értékű pálinka, amely keresett a világpiacon. A Magyarországon készített kajsziaszalványnak nincs jelentősége, ennek oka, hogy nincsenek hozzá megfelelő fajták (Surányi, 2011).

A friss piac és a feldolgozó ipar is a jó minőségü, kiváló beltartalmi értékekkel rendelkező gyümölcsöket igényli. A gyümölcs minősége komplex fogalom, amely magába foglalja a gyümölcs fizikai, kémiai, fizikokémiai jellemzőit, amelyek alapvetően meghatározzák a fogyasztói megítélését (Kramer és Twigg, 1966; Stow, 1995; Szalay és Balla, 2003). A különböző felhasználási célok a minőség szempontjából eltérő követelményeket támasztanak a gyümölccsel szemben. Friss fogyasztás szempontjából az attraktív megjelenésü, jól szállítható és hosszú időn át pulton tartható gyümölcsök a keresettek. A feldolgozóipar a különböző termékek 
készítésénél eltérö gyümölcsminőségi tényezőket (húsállomány, aroma, szép szín, megfelelö egészségügyi állapot) vesz figyelembe (Abbot, 1999; Horváth, 2003). A leggyakoribb fogyasztói panaszok a gyümölcsnek az édes íz hiányából adódnak (Moreau-Rio és Roty, 1998). Az új kajszifajtáknak olyan minőségi tulajdonságokkal kell rendelkezniük, amelyek kielégítik a fogyasztói igényeket (Ruiz és Egea, 2008).

\subsection{A gyümölcsök fizikai jellemzőinek változása az érés során}

A gyümölcs kialakulása három szakaszra bontható, amelyet kettős szigmoid görbével tudunk leírni (Ghorpade és Hanna, 1995). Az első szakaszra a sejtek osztódása és a kezdeti intenzív növekedés jellemző. A zigóta nyugalmi állapotban van, a termésfal, a maghéj, illetve az endospermium gyorsan növekszik (Surányi és Molnár, 1981; Ghorpade és Hanna, 1995). A második szakaszban csökken az osztódás intenzítása, a kőmag kialakulása ekkor a legintenzívebb, az endokarpium lignifikálódik (Surányi, 2011). A harmadik szakaszban a gyümölcs növekedése ismét felgyorsul, a gyarapodás elérheti a teljes tömeg kétharmad részét is. Ebben az időszakban a gyümölcshús sejtmegnyúlással gyarapszik (Szalay, 2003).

A gyümölcs méretét számos tényezö határozza meg, úgymint a fajta genetikai háttere, a fának az életkora, a virágok berakódottsága, valamint a termesztési és környezeti tényezők. Ezek a tényezők különbözöképpen hatnak a gyümölcs nagyságára. A termésarány és a gyümölcs érési mérete egy telítődési görbével írható le (Surányi és Szalay, 2011). A gyümölcsök mérete legintenzívebben az érés előtt növekszik (Surányi és Molnár, 1981). A kajszifajtákat tömegük alapján több kategóriába tudjuk sorolni:

- kisgyümölcsüek: 30-40 g, pl. rózsakajszik;

- közepes: 40-55 g, pl. 'Gönci magyar kajszi';

- nagyméretü: 55-70 g, pl. 'Mandulakajszi';

- igen nagy: 70-100 g, pl. óriás típusú fajták (Szalay, 2009).

Soltész (1997) szerint a nagy áruértékü kajszinál a gyümölcsátmérő alsó határa 40 mm. Pedryc és Hermán (2011) nagyméretü kajszinak a 60 g-nál nagyobb tömegü vagy 50 mm-nél nagyobb átméröjü gyümölcsöt tekintik. A kajszi méretét a legnagyobb átmérő szerint (hossztengelyre merölegesen mérve) kell meghatározni. Az "Extra" és az I. osztályokban kötelező a méret szerinti osztályozás (3. táblázat). 
3. táblázat: A legkisebb méret az egyes osztályoknál (Codex Alimentarius Hungaricus: 3-1558/93 alapján)

\begin{tabular}{lc}
\hline Osztály & Legkisebb átmérő (mm) \\
\hline Extra & 35 \\
I. és II. (méretre osztályozás esetén) & 30 \\
II. (ha nincs méretre osztályozva) & 30 \\
\hline
\end{tabular}

A húskeménység a kajszigyümölcs alapvető minőségi tulajdonsága (Bassi et al., 1992; Bureau et al., 2006), amely meghatározza a szüreti időpontot, az áruvá készítésre, valamint a feldolgozásra való alkalmasságot (Bruhn et al., 1991). A kajszi minőségi jellemzői, beleértve a húskeménységet, alapvetően függnek a genetikai tényezőktől, a fajta öröklött tulajdonságaitól (Asma és Ozturk, 2005; Ruiz és Egea, 2008), de azt befolyásolják a környezeti tényezők, valamint a termesztéstechnológia is (Crossa-Raynaud és Audergon, 1991). A kajszigyümölcs húskeménysége az érés és az utóérés során folyamatosan változik. A húsállomány egyre puhább lesz. A húskeménység változásának ütemét szintén az öröklött tulajdonságok és a környezeti tényezők határozzák meg (Szalay és Balla, 2003).

Számos szakirodalom számol be a Magness-Taylor-féle kézi penetrométerrel mért gyors húskeménységi értékekről, amely a nyomófeszültség mérésén alapuló állományvizsgálati módszer. A minta keménységét a behatolás során mért maximális erő (roncsolási feszültség) és a deformáció alapján számítja (Borsa et al., 2002; Farina et al., 2010; Leccese et al., 2010). Farina et al. (2010) két kajszifajta, a 'Vitillo' és a 'Pellecchiela' húskeménységét vizsgálták kézi penetrométer segítségével három különböző érettségi állapotban. Megállapították, hogy a két fajta húskeménysége az érés elörehaladtával csak az utolsó érettségi állapotban csökkent jelentősen. Kovács et al. (2008) Labor MIM típusú penetrométer segítségével vizsgálták a 'Magyar kajszi C.235' és a 'Bergeron' húskeménységét különböző érettségi állapotokban. Megállapították, hogy fehéreszöld állapotban szignifikánsan keményebb volt a gyümölcs, mint szalmasárga és világossárga állapotban. Ez a gyors vizsgálati módszer alkalmas a gyümölcsök húskeménységének megállapítására, de pontosabb eredményeket laboratóriumi műszerek segítségével kaphatunk.

A korszerü állománymérő műszerek segítségével komplex állományprofil-elemzést végezhetünk. A különböző mérőfejekkel és különböző programok segítségével nemcsak a húskeménységet, hanem számos más állományjellemzőt is meg tudunk határozni, mint például az adhéziós erő, kohéziós erő, rugalmasság, rágósság, stb. (Bourne 1966, 1978, 1982). Az 
adhézió vagy más néven tapadás azt mutatja meg, hogy a mérőfejhez tapadt mintát mekkora munkával lehet eltávolítani. A kohézió a második és az első kompressziós ciklus alatt mért pozitív erőértéknek a hányadosa, míg a rágósság a keménység, a kohézió és a rugalmasság szorzata (Bourne, 1978).

Lifen (2009) két őszibarackfajta húskeménységét határozta meg állománymérő müszer segítségével és az általa vizsgált két fajtánál hasonló húskeménységi értékeket mutatott ki. Ficzek et al. (2011) almahibridek állományparamétereit (húskeménység, adhéziós erő, kohéziós erő és rágósság) vizsgálták optimális szüreti időpontban és négy hónap hütőtárolást követően Brookfield CT3 típusú állománymérő müszer segítségével. Eredményeik alapján megállapították, a vizsgált fajtajelöltek különböző feldolgozási célokra való alkalmasságát.

\subsection{A gyümölcsök kémiai jellemzőinek változása az érés során}

Az érés során lebontó és felépítő biokémiai folyamatok zajlanak a gyümölcsökben, amelyek következtében beltartalmi összetevőik folyamatosan változnak (Szalay, 2003). Az érés során különböző cukrok keletkeznek, a legfontosabbak ezek közül a szacharóz, a fruktóz, a glükóz és a xilóz, de kisebb mennyiségben más egyszerü és összetett cukrok is előfordulnak (Anet és Reynold, 1955). A szakirodalmakban közzétett cukortartalom átlagos értéke 6,05\%, 1,57-11,85\% szélsőértékekkel (Ghorpade és Hanna, 1995). Souci et al. (2008) tápanyagtáblázata alapján a szacharóz tartalom a kajszi gyümölcseiben 3600-5980 mg/100g, a glükóz mennyisége pedig $950-2880 \mathrm{mg} / 100 \mathrm{~g}$.

15 kajszifajta gyümölcsének cukorösszetételét Štampar et al. (1999) HPLC berendezéssel vizsgálták. A 4. táblázatban néhány általuk mért kajszifajta cukorösszetételét mutatjuk be.

4. táblázat: Kajszifajták cukorkomponenseinek mennyisége g/kg (Štampar et al., 1999)

\begin{tabular}{lccccc}
\hline \multicolumn{1}{c}{ Fajta } & Szacharóz & Glükóz & Fruktóz & Xilóz & Szorbitol \\
\hline Laycot & 66 & 29 & 13,4 & 5 & 6,1 \\
Hargrand & 79,8 & 31,9 & 11,0 & 5,5 & 5,2 \\
Aurora & 43,4 & 23,9 & 6,4 & 0,4 & 0,2 \\
Harcot & 79,5 & 22,7 & 10,1 & 5,6 & 4,8 \\
Goldrich & 63,5 & 31,1 & 12,9 & 4,7 & 2,4 \\
Orange Red & 54,9 & 35,4 & 17,5 & 4,3 & 2,8 \\
\hline
\end{tabular}


Bureau et al. (2006) 10 különböző szedési időben vizsgálták a 'Bergeron' cukorkomponenseit az érés során. Eredményeik alapján a glükóztartalom nem változott az érés elörehaladtával, a fruktóztartalom kis mértékben növekedett, míg a szacharóztartalom növekvő tendenciát mutatott. Németh (2012) modellezte a cukorkomponensek alakulását az érés során. A szacharóz mennyiségének növekedését logisztikus görbével írta le, a glükóz változását két szakaszra bontotta, az első szakaszban másodfokú görbét illeszthetett rá, a második szakaszban nem volt jelentős változás.

Az érés másik fontos lebontó folyamata a savtartalom csökkenése. A szerves savak közül a kajsziban leginkább a citromsav, az almasav, a borostyánkősav és a galakturonsav fordul elő (Anet és Reynolds, 1955). A kajsziban az almasavtartalom 700-1300 mg/100g közé esik, a citromsav mennyisége 140-700 mg/100 g, a borostyánkősav: 10 mg/100 g (Souci et al. 2008).

Štampar et al. (1999) 15 kajszifajta gyümölcsének nem csak a cukorkomponenseit vizsgálták HPLC berendezéssel, hanem a savkomponenseket is. Az 5. táblázatban néhány általuk mért kajszifajta három savkomponensét mutatjuk be.

5. táblázat: Kajszifajták savkomponensei g/kg (Štampar et al., 1999)

\begin{tabular}{lccc}
\hline \multicolumn{1}{c}{ Fajta } & Almasav & Citromsav & Fumársav \\
\hline Laycot & 14,3 & 20,3 & 9,9 \\
Hargrand & 18,1 & 9,9 & 17,7 \\
Aurora & 32,6 & 0,6 & 13,3 \\
Harcot & 21,4 & 14,6 & 12,7 \\
Goldrich & 16,4 & 15,4 & 17 \\
Orange Red & 15,5 & 12,2 & 16,3 \\
\hline
\end{tabular}

Bureau et al. (2009) a 'Bergeron’ fajtánál vizsgálták a savösszetevők alakulását az érés előrehaladtával. Vizsgálataik alapján megállapították, hogy az almasav mennyisége csökkent az érés során. A citromsavtartalom növekedő tendenciát mutatott, az utolsó szedési időpontban számoltak be egy hirtelen csökkenésröl. Németh (2012) három kajszifajtánál vizsgálta a savösszetevők alakulását az érés során. Az alma- és borostyánkősav változását az érés során inverz modellel írta le, a citromsav az első három időpontban csökkent, majd enyhén növekedett, s utána állandóvá vált.

A cukor és a sav optimális aránya kedvezően hat a gyümölcs ízére (Azodanlou et al., 2003). Magas cukor/sav arány a kajszi esetében magasabb gyümölcsminőségre utal (Ledbetter et 
al., 2006). Az érés elörehaladtával a cukortartalom növekszik, a savtartalom pedig csökken, ennek következtében növekszik a cukor/sav arány is (Gómez és Ledbetter, 1997). Ledbetter et al. (2006) az 1394-1-es kajszihibrid esetében magas Brix-fokot $(23,0)$ és alacsony savtartalmat $(0,46 \%)$ mértek, az ebből számított cukor/sav arány kivételesen magas volt $(50,0)$, melyböl magasabb gyümölcsminőségre következtettek. Bhat et al. (2013) kiemelkedő magas cukor/sav arányt $(83,85)$ mértek a 'Charmagz' nevü kajszifajta esetében, amely értéket a fajta magas cukortartalmának és alacsony savtartalmának hányadosaként kapták.

A gyümölcs minőségét alapvetően befolyásolja a szedési idő helyes megválasztása (Farina et al., 2010; Aubert et al., 2010; Stéger-Máté et al., 2010). A fajták különböző felhasználási célokra való optimális szedési idejét csak úgy tudjuk meghatározni, ha ismerjük a gyümölcseikben lejátszódó folyamatokat, fizikai paramétereik és beltartalmi értékeik változásának ütemét az érés során (Szalay és Balla, 2003).

\subsection{Antioxidáns és egyéb biológiailag aktív vegyületek}

A funkcionális élelmiszerek fontos szerepet játszanak a betegségek megelőzésében és/vagy kezelésében, mint például a vérszegénység esetében is. Ezek vegyületeit biológiailag aktív komponenseknek nevezzük, ilyenek pl. a karotinoidok, a polifenolok, bizonyos vitaminok és rostok (Madrau et al., 2009). A kajszi gyümölcse gazdag forrása a fent említett fitokemikáliáknak, főleg a polifenoloknak (Garcia-Viguera et al., 1997; Radi et al., 1997; Ilja et al., 2000; Dragovic-Uzelac et al., 2005; Ruiz et al., 2005b; Erdogan-Orhan és Kartal, 2011) és a karotinoidoknak (Fraser és Bramley, 2004; Sass-Kiss et al., 2005.; Dragovic-Uzelac et al., 2007; Zaghdoudi et al., 2015)

\subsubsection{Polifenolok}

A polifenolok a növények másodlagos anyagcsere-termékei, megvédik a növényeket a különféle stresszhatásoktól (Haminiuk et al., 2012; Cheynier, 2012). Igen változatos kémiai szerkezettel rendelkeznek, vannak közöttük egyszerü molekulák (stilbének, flavonoidok, tanninok) és polimer vegyületek (Naczk és Shahidi, 2004; Andersen és Markham, 2006). Az alapvázhoz egy vagy több hidroxil-csoport kapcsolódik, de más vegyületek is képesek kapcsolódni hozzá úgy, mint a cukrok vagy szerves savak (Harborne és Williams, 2000; Ferreres et al., 2009). A polifenol vegyületeknek antioxidáns, antikarcinogén és gyulladáscsökkentő hatása is van (Lugasi, 2000; Tripoli et al., 2007) 
A gyümölcsökben az antioxidáns hatású vegyületek mennyiségét a genotípus határozza meg (Cantin et al., 2009; Scalzo et al., 2005). Alma esetében az évjárat hatását is igazolták már (Sluis et al., 2001). A korai érésű kajszifajták gyümölcseinek összes polifenol-tartalma kisebb, mint a késői érésűeké (Leccese et al., 2008). Dragovic-Uzelak et al. (2007) vizsgálati eredményeiből megállapították, hogy a polifenolos vegyületek mennyisége a kajsziban az érés elején csökkent, később stagnált, vagy kis mértékben növekedett.

Németh (2012) három kajszifajta ('Harcot', 'Bergeron' és 'Gönci magyar kajszi') polifenol-tartalmát vizsgálta különböző érettségi stádiumokban 2010-ben. Kiemelkedő polifenoltartalmat mért a 'Harcot' fajtában. A 'Gönci magyar kajszi' gyümölcseiben 60 és 70\%-os érettségben magasabb volt a polifenol-tartalom, mint a 'Harcot' gyümölcseiben, viszont a többi érettségi stádiumban csak kis mértékben növekedett. A 'Harcot' és 'Bergeron' esetében az érés elörehaladtával növekvő polifenol-tartalmat tudott kimutatni.

Hegedűs (2013) kajszifajták összes polifenol-tartalmát vizsgálta. 2006-ban 0,082 és 2,892 mg GS/ml, míg 2007-ben 0,169 és 3,5 mg GS/ml között változott a fajták polifenoltartalma. A korai érésű fajták gyümölcseiben mérte a legkisebb összes polifenol-tartalmat, míg kiemelkedő polifenol-tartalommal a 'Preventa' rendelkezett. Eredményeiből azt is igazolta, hogy az összes polifenol-tartalom kialakítása szempontjából a genotípus meghatározó jelentőségű, illetve az összes polifenol-tartalmat az évjárat is szignifikánsan befolyásolta. Wani et al. (2015) vizsgálati eredményei alapján a kajszifajták összes polifenol-tartalma 8,77-12,11 mg GAE / g volt.

\subsection{2. $\beta$-karotin}

A karotinoidok sárga vagy piros színanyagok, amelyek a gyümölcsök és zöldségek színét adják (Sies, 1993). Fontos szerepet játszanak a peroxidgyökök közömbösítésében (Skibsted, 2012). A karotinoidok tetraterpén származékok, zsírban oldódnak. A kajsziban a következő karotinoidok találhatók meg: ß-karotin (1.ábra), ß-kriptoxantin, $\gamma$-karotin, likopin és lutein (Sass-Kiss et al., 2005; Ruiz et al., 2005a). A legelterjedtebb változat a $\beta$-karotin, ami a karotináz enzim segítségével A-vitaminná bomlik. Az A-vitaminnak fontos szerepe van a látásban (Rando, 1990). A kajszi magas ß-karotin tartalommal rendelkezik (Doymaz, 2004; Jiménez et al., 2008; Kurz et al., 2008; Sharma et al., 2012).

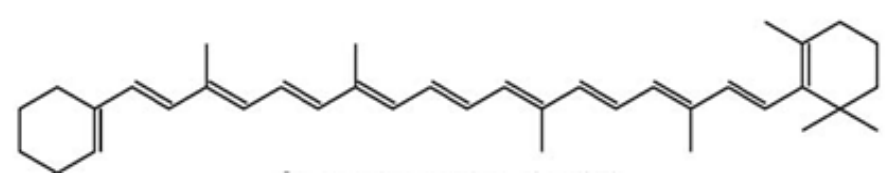

1. ábra: A ß-karotin szerkezete 
Rowe (1996) szerint azoknál az embereknél, akik gyümölcsökben és zöldségekben gazdag étrendet fogyasztanak, kisebb eséllyel alakulnak ki daganatos megbetegedések, mint akik kevesebb gyümölcsöt és zöldséget esznek. Vérplazmájukban magasabb ß-karotin-tartalmat mutattak ki. Hercberg et al. (1999) szerint a gyümölcs fogyasztása a ß-karotin-tartalom antioxidáns hatása miatt segíti a rákos és érrendszeri megbetegedések megelőzését és gyógyítását.

A kajszi karotinoid-tartalma az érés során fokozatosan növekszik (Katayama et al., 1971; Dragovic-Uzelak és et al., 2007). A kajszi ß-karotin-tartalma 0,6-6,4 mg/100g közé esik (Souci et al., 2008). Akin et al. (2008) Törökországban 11 kajszifajta $ß$-karotin-tartalmát vizsgálták. A ß-karotin mennyisége 5,74-48,69 mg/100 g között alakult. A legnagyobb ß-karotin-tartalma az 'Alyanak' fajtának volt, míg legkisebb értéket a 'Çöloğlu’ esetében mértek. Ruiz et al. (2006) spanyol kajszifajták ß-karotin-tartalmát vizsgáltak 90\%-os érettségben, a gyümölcsök karotintartalma 1,51-16,5 mg/100 g között alakult. Németh et al. (2011b) három kajszifajta ß-karotin tartalmát vizsgálta két évben $(2008,2010)$, öt különböző érettségi stádiumban $(60 \%, 70 \%, 80 \%$, 90\%, 100\%). A ß-karotin-tartalom 1,2-4 mg/100 g között alakult. A 'Gönci magyar kajszi' esetében az érés elörehaladtával a ß-karotin- tartalom kezdetben emelkedett, majd stagnált. 2008ban 80\%-os érettségben, míg 2010-ben 90\%-os érettségben elérte a legmagabb mennyiséget, utána már nem növekedett a ß-karotin-tartalma. 


\section{CÉLKITÜZÉSEK}

Kísérleti munkánk megkezdésekor célul tüztük ki külföldön nemesített kajszifajták fagytürésének, mikrosporogenézisének, érésbiológiai jellemzőinek és gyümölcsminőségi paramétereinek részletes meghatározását, $\mathrm{s}$ ezáltal hazai termesztésre való alkalmasságuk igazolását. Összehasonlító fajtaként régóta termesztett magyar fajtákat választottunk. A hagyományos vizsgálati módszerek mellett korszerü laboratóriumi módszereket is alkalmaztunk.

Részletes célkitüzések:

1. Kajszifajták fagytürésének meghatározása mesterséges fagyasztásos kísérletekkel.

2. A virágszervek fagytürését befolyásoló évjárathatás kimutatása statisztikai vizsgálatokkal.

3. Kajszifajták csoportosítása fagyérzékenységük alapján.

4. Kajszifajták mikrosporogenézis ütemének és sorrendjének meghatározása több évjáratban.

5. A gyümölcshúsállomány érés alatti változásának monitorozására és a fajták közötti különbségek kimutatására alkalmas műszeres mérési módszerek összehasonlítása.

6. Külföldi és hazai kajszifajták gyümölcsminőségi paramétereinek elemzése.

7. Kajszifajták cukor- és savprofiljának meghatározása.

8. Kajszifajták húskeménysége és vízoldható szárazanyag-tartalma közötti összefüggés modellezése.

9. Kajszifajták ß-karotin- és polifenol-tartalmának meghatározása.

Tehát a kajszifajták termésbiztonságával és piaci értékeik meghatározásával kapcsolatos területeken kívántuk bővíteni az ismereteket új kutatási eredményekkel. 


\section{ANYAG ÉS MÓDSZER}

\subsection{A kísérleti minták származási helye, a termőhely adottságai}

A kísérletekhez a mintákat a Budapesti Corvinus Egyetem Gyümölcstermő Növények Tanszék Soroksáron elhelyezkedő kísérleti ültetvényéből gyüjtöttem. A területe évi átlagos napfénytartalma 2014 óra. A hőmérséklet napi és évi ingadozása jelentős, az évi középhőmérséklet $11^{\circ} \mathrm{C}$, a csapadék mennyisége kevés, átlagosan évi 500-600 mm, amely egyenlőtlenül oszlik meg a vegetációban, jelentős része május-júniusban esik. Az uralkodó szélirány ÉNy-i. A terület talajtípusa a Duna meszes homokhordalékán képződött öntéstalaj.

A kísérleti ültetvényben 2004-ben telepítették az első kajszifákat, azóta a fajtagyüjteményt folyamatosan bővíti a Tanszék. A fajtagyűjtemény 3 fás parcellákkal létesült, de a fontosabb fajták több ismétlésben is megtalálhatók. Így a vizsgálatainkhoz a 'Gönci magyar kajszi', a 'Ceglédi bíborkajszi' és a 'Rózsakajszi C.1406' fajtákból 6 db fa, a többi fajtából pedig $3 \mathrm{db}$ fa állt rendelkezésre. A fák myrobalan alanyon állnak és alacsony törzsü, kompakt váza koronaformát alakítottak ki belölük 5 x 3 méteres sor- és tőtávolsággal. A sorközök füvesítettek. Az ültetvényben kiépített csepegtetö öntözörendszer van, s integrált termesztéstechnológiát alkalmaznak. A vizsgálatokat három egymás utáni évjáratban, 2010/11, 2011/12, 2012/13-ban végeztük.

A 2010/2011-es évben Soroksáron még fiatalok voltak a külföldi fajták fái, így a Vitamór Kft. fagyveszélyesség szempontjából hasonló adottságokkal rendelkező, Móron található kajsziültetvényéből is történt mintavétel. A város Fejér megye északnyugati területén, a Vértes és a Bakony hegységek között fekvő völgyben, a Móri-árokban helyezkedik el. Az ültetvényben korszerü, integrált gyümölcstermesztést folytatnak. A talaj típusa Ramann-féle barna erdőtalaj és ennek homok szövetű változata. A csapadék mennyisége évi átlagosan $692 \mathrm{~mm}$, az évi középhőmérséklet $10,1^{\circ} \mathrm{C}$ (Kiss, 1992). Az évi átlagos napfénytartam 1900-2000 óra.

\subsection{A vizsgálati évek hőmérsékleti adatai}

Az áttelelő szervek fagyállóság-változásának értékeléséhez fontos tudnunk a téli nyugalmi időszak alatti hőmérséklet alakulását. A soroksári kísérleti ültetvényben müködő meteorológiai állomás napi minimum, napi maximum és napi átlaghőmérséklet adatait gyüjtöttük össze a vizsgálati időszakban. A hőmérsékleti adatokat felhasználtuk a kísérleti eredményeink értékeléséhez. 


\subsection{Vizsgálatba vont fajták}

A soroksári fajtagyüjteményből összesen 20 kajszifajtát választottunk ki a részletes vizsgálatokhoz. A vizsgálatba vont fajtákat a 6. táblázatban mutatom be.

6. táblázat: A vizsgálatba vont kajszifajták

\begin{tabular}{ccc}
\hline $\begin{array}{c}\text { Mesterséges } \\
\text { fagyasztásos }\end{array}$ & $\begin{array}{c}\text { Mikrosporogenézis } \\
\text { folyamatának vizsgálata 2010- }\end{array}$ & $\begin{array}{c}\text { Beltartalmi vizsgálatok } \\
\text { vizsgálatok 2010-2013 }\end{array}$ \\
\hline Ceglédi bíborkajszi & Gönci magyar kajszi & Gönci magyar kajszi \\
Gönci magyar kajszi & Comandor & Sylvercot \\
Rózsakajszi C.1406 & Harcot & Pinkcot \\
Sylvercot & Harlayne & Goldrich \\
Pinkcot & Harogem & Orange Red \\
Goldrich & Litoral & Veecot \\
Sylred & Orange Red & Aurora \\
Pisana & Pinkcot & Bergarouge \\
Laycot & Sirena & Budapest \\
Orange Red & & Mandulakajszi \\
Sweet Red & & Harcot \\
Veecot & & Harogem \\
Aurora & & Litoral \\
Bergarouge & & \\
Harlayne & & \\
\hline
\end{tabular}

A fagytürési vizsgálatok elvégzéséhez előzetes vizsgálati eredmények alapján a fajtagyüjteményből három eltérő fagytürőképességü standard fajtát választottunk ki. Ezek a fagyérzékeny 'Ceglédi bíborkajszi', a közepesen fagytürő 'Gönci magyar kajszi', és a jó fagytürőképességgel rendelkező 'Rózsakajszi C.1406'. E három fajtát részletesen vizsgáltuk mind a három téli nyugalmi időszakban. Minden évjáratban külföldi fajtákat is bevontunk a vizsgálatba. A 'Sylvercot', a 'Pinkcot', és a 'Goldrich' fajtákat mind a három évjáratban vizsgáltuk. A 'Sylred', a 'Pisana', és a 'Laycot' a 2010/11-es évjáratban, az 'Orange Red', a 'Sweet Red' és a 'Veecot' a 2011/12-es évjáratban, az 'Aurora', a 'Bergarouge' és a 'Harlayne' a 2012/13-as évjáratban volt vizsgálatba vonva. 
A mikrosporogenézis folyamatát három egymás utáni évjáratban, 2010/11, 2011/12 és 2012/13 telén vizsgáltuk. Három Romániából (Ro) és öt Észak-Amerikából (Am) származó fajtát vizsgáltunk. Ezek a következők voltak: 'Comandor' (Ro), 'Harcot' (Am), 'Harlayne’ (Am), 'Harogem' (Am), 'Litoral' (Ro), 'Orange Red' (Am), 'Pinkcot' (Am), 'Sirena' (Ro). Kontrollként a 'Gönci magyar kajszi’ fajta szerepelt a vizsgálatban.

A gyümölcsök beltartalmi értékeit két évben, 2011-ben és 2013-ban vizsgáltuk. 2012-ben jelentős fagykár volt a soroksári kísérleti ültetvényben, nem tudtunk kajszit szüretelni, így a vizsgálatokat sem tudtuk elvégezni. A gyümölcsminőségi paraméterek meghatározásához standard fajtaként a magyarországi ültetvényekben az egyik legelterjedtebb, kiváló gyümölcsminőséggel rendelkező 'Gönci magyar kajszi' szerepelt. S ehhez hasonlítottuk a vizsgálatba vont többi fajtát, amit a 6. táblázatban soroltunk fel. Vizsgáltuk a gyümölcsök tömeg- és méretparamétereit, magtömegét, alapszínét, húskeménységét, vízben oldható szárazanyagtartalmát, valamint titrálható savtartalmát.

2011-ben 9 kajszifajta ('Budapest', 'Ceglédi arany', 'Gönci magyar kajszi’, 'Mandulakajszi', 'Hargrand', 'Harlayne', 'Harogem', 'Veecot', 'Laycot') húskeménységének változását az érés során többféle módszerrel is meghatároztuk. 2013- ban vizsgáltuk továbbá 8 ígéretes külföldi kajszifajta ('Litoral', 'Pinkcot', 'Sylvercot', 'Goldrich', 'Bergarouge', 'Harcot',

'Orange Red', 'Veecot') állományparamétereinek alakulását közvetlenül a szüret után. Kontrollként a 'Gönci magyar kajszi' szerepelt.

Meghatároztuk a gyümölcsök ß-karotin- és polifenol-tartalmát három külföldi fajta ('Pinkcot', 'Sylvercot', 'Veecot') és a kontroll 'Gönci magyar kajszi' esetében. A cukor- és savösszetevők arányát a 2011-es és 2013-as évben a következő fajtáknál vizsgáltuk: 'Pinkcot', 'Sylvercot', 'Goldrich', 'Veecot', 'Harcot', 'Harogem'. Kontroll a 'Gönci magyar kajszi’ volt.

\subsection{A virágrügyek és a virágok fagykárosodásának meghatározása mesterséges fagyasztással}

A mesterséges fagyasztásos vizsgálatokat három egymás utáni téli nyugalmi időszakban végeztük, azaz 2010/2011, 2011/2012, 2012/2013 telén. 2011, 2012 és 2013 tavaszán, a virágzási időszakban is részletes vizsgálatokat végeztünk a különböző fenológiai fázisban lévő virágok fagyállóságának meghatározása érdekében.

A mintavétel úgy történt, hogy egy-egy alkalommal fajtánként 6 db hosszú vesszőt vágtunk le a fákról (50-80 cm közötti hosszúságúakat), és a vesszők alsó részén rovásokkal 
jelöltük meg a minta sorszámát. A virágzási időszakban a zárt csészebimbós állapottól a virágzás végéig 3-4 naponként gyüjtöttünk termővesszőket a fákról. A mintavételi időpontokat és az alkalmazott kezelési hőmérsékleteket a M.2.1-M.2.3. táblázatokban tüntettük fel.

$\mathrm{Az}$ áttelelő szervek fagyállóságát mesterséges fagyasztással határoztuk meg. A mesterséges fagyasztásos kezelések Rumed 3301 (Rubarth Apparate GmbH) típusú klímakamrában történtek. Négy, szükség esetén öt fagyasztási hőmérsékletet alkalmaztunk minden vizsgálati időpontban. A lehütés és a felmelegítés sebessége óránként $2{ }^{\circ} \mathrm{C}$ volt. Az adott kezelési hőmérsékleten 4 órán keresztül voltak a vesszők, a kezelési hőmérsékletek között általában $2{ }^{\circ} \mathrm{C}$ különbség volt. Kezelés után legalább 12 órán át szobahőmérsékleten voltak a vesszők. A fagykárosodás mértékét a rügyek elmetszésével értékeltük, a belső szövetek elbarnulása alapján. A megbarnult szöveteket károsodottnak tekintettük, míg a zöld szöveteket épeknek (2. ábra).

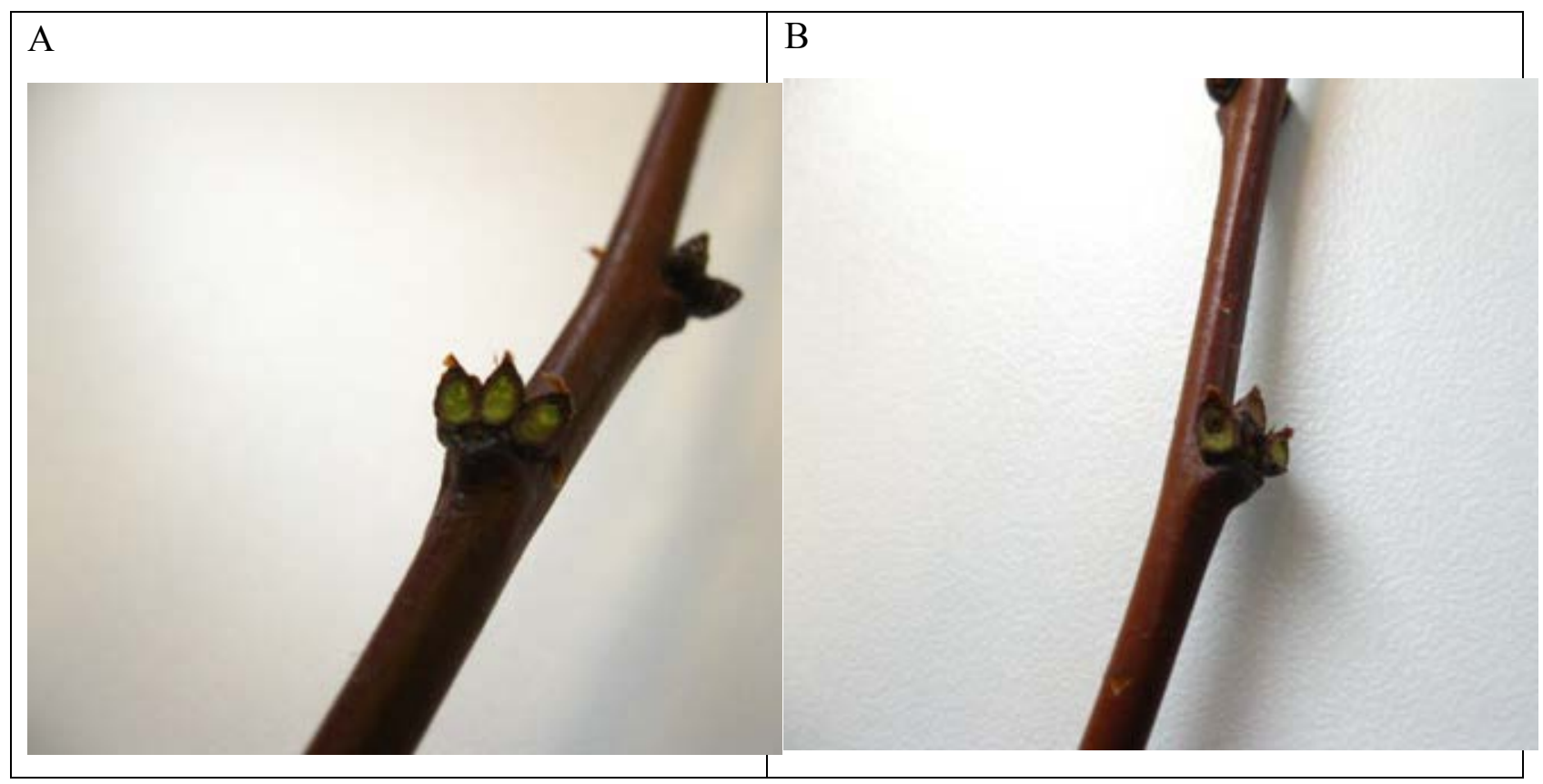

2. ábra: Kajszi ép (A) és fagykárt szenvedett (B) virágrügyei

Minden vizsgálati időpontban meghatároztuk a genotípusra jellemző fagytürési középértéket $\left(\mathrm{LT}_{50}\right)$. Ez azt a hőmérsékletet jelenti, amely az adott időpontban 50\%-os fagykárosodást okoz. A fagykárosodás mértékét a kezelési hőmérsékletek függvényében ábrázolva mindig szigmoid görbét kapunk (3. ábra). A fagytürési középértéket lineáris regressziós modell alkalmazásával határoztuk meg, feltételezve, hogy a kapott szigmoid görbének a $20 \%$ és a $80 \%$ közötti szakasza lineárisnak tekinthető (Gu, 1999). A regresszióanalízist az IBM SPSS 20 statisztikai szoftver segítségével végeztük. 


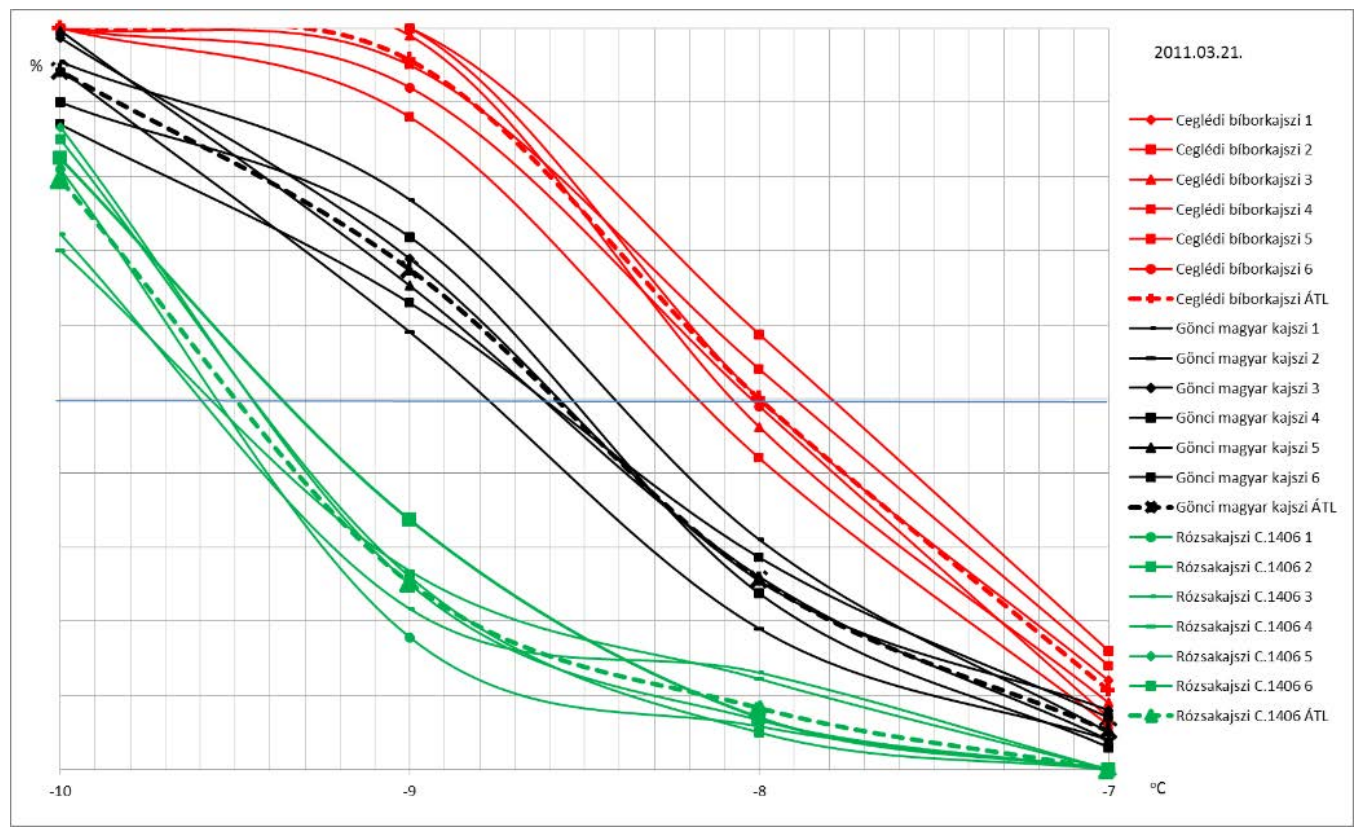

3. ábra: Minta grafikon (szigmoid görbék)

A virágzási időszakban 3-4 naponként végeztünk mesterséges fagyasztásos vizsgálatokat. Klímakamrában több kísérleti hőmérsékleten kezeltük a termővesszőket, majd a kezelés után a különböző fenológiai stádiumban lévő bimbókat/virágokat szétválogattuk, és az $\mathrm{LT}_{50}$ értékeket fenológiai fázisonként határoztuk meg.

\subsection{A mikrosporogenézis folyamatának vizsgálata a kiválasztott kajszifajtákban}

Három egymás utáni évjáratban végeztük a vizsgálatokat, 2010/11, 2011/12 és 2012/13 telén. A téli nyugalmi időszak során hetente (szükség esetén hetente többször) gyüjtöttük a kijelölt fákról a termőgallyakat, és a rajtuk lévő nyársak oldalán elhelyezkedő virágrügyeket vizsgáltuk. A virágrügyekből kivettük a portokokat, azokat tárgylemezre helyeztük, kármin ecetsavval festettük, majd fedőlemezzel lezártuk. Ezután a tárgylemez enyhe megnyomása után mikroszkóppal vizsgáltuk a portokokon belüli szövetállományt. Minden alkalommal genotípusonként 8-10 virágrügyben lévő portokokat vizsgáltunk. Feljegyeztük azt, hogy a tárgylemezen a mikrosporogenézis melyik fenológiai stádiumai láthatók, és melyik hány százalékban. Hat fejlődési stádiumot különböztettünk meg:

(1) Archespórium állapot - a portokokban differenciálatlan szövetállomány, archespórium található.

(2) Füzér állapot - a portokokban megkezdődött az archespórium szövet differenciálódása, a fokozatosan kialakuló pollen anyasejtek még összetapadva, füzérekben láthatók. 
(3) Pollen anyasejt állapot - a portokokban kész pollen anyasejtek találhatók, amelyek a tárgylemezen egymástól elkülönülve láthatók.

(4) Tetrád állapot - a pollen anyasejtekben megtörtént a redukciós osztódás, a 4 részre történt osztódás következtében létrejött tetrádok találhatók a portokokban.

(5) Mikrospóra állapot - minden pollen anyasejtből 4 mikrospóra képződött, ezek elkülönülten találhatók a portokokban.

(6) Pollen állapot - kialakultak a végleges pollenszemek, a portokokban a genotípusra jellemző alakú és mintázatú pollenek találhatók.

A mikrosporogenézis folyamatát grafikonon ábrázolva szigmoid görbéket kaptunk. A fenológiai stádiumok fokozatosan mentek át egymásba. A statisztikai elemzés során a szigmoid görbék 50\%-os értékhez tartozó kvantilisét tekintettük az átmenet időpontjának a mikrosporogenézis folyamatában, a virágzáskezdet fázisában pedig az 5\%-os értékhez tartozó kvantilist vettük figyelembe, mivel az ültetvényben azt tekintjük a virágzáskezdet napjának, amikor a virágok 5\%-a kinyílt. A fenológiai folyamatok elemzése során az időpontokat a január 1-től eltelt napok számával jellemeztük.

\subsection{Kajszifajták fizikai paramétereinek meghatározása}

A Kísérleti ültetvényben megszedett mintáknak a fizikai és beltartalmi tulajdonságait a Gyümölcstermő Növények Tanszék analitikai laboratóriumában vizsgáltuk. Fajtánként 30 db gyümölcsöt vizsgáltunk, minden érettségi állapotban 10 db-ot. A fajták különböző érettségi állapotát korábbi kísérleti eredmények alapján a húskeménység és az alapszín szerint határoztuk meg. A minták szedésének napján elvégeztük a gyors fizikai és beltartalmi vizsgálatokat. A további beltartalmi paraméterek vizsgálatához fajtánként $10 \mathrm{db}$ gyümölcshúst turmixoltunk össze, és fagyasztva $-25^{\circ} \mathrm{C}$-on tároltuk.

\subsubsection{Tömeg és méretparaméterek vizsgálata}

A vizsgálatba vont fajtáknál a gyümölcsök méretparamétereit (magasság, szélesség, vastagság) Mitutoyo CD-15DC típusú digitális tolómérővel mértük meg. A tömeget KPZ-2-05-4/6000 típusú digitális mérlegen határoztuk meg. Fajtánként $30 \mathrm{db}$ gyümölcs tömeg és méretparamétereit vizsgáltuk. 


\subsubsection{Gyümölcshús állomány vizsgálata}

A gyümölcsök húskeménységét Magness-Taylor-féle kézi penetrométerrel határoztuk meg, melyhez $8 \mathrm{~mm}$ átmérőjü és $0,5 \mathrm{~cm}^{2}$ felületű mérőfejet használtunk. A gyümölcsök héját vékonyan eltávolítottuk, s a gyümölcsök mindkét oldalát, a napos és árnyékos oldalt egyaránt vizsgáltuk. A kézi penetrométerrel történt vizsgálatok eredményei alapján a gyümölcsök húskeménységét $\mathrm{kg} / \mathrm{cm}^{2}$ értékben adtuk meg. Ezt úgy számítottuk ki, hogy a behatoláshoz szükséges erőt elosztottuk a mérőfej felületével.

A gyümölcshús állományparamétereit műszeresen is vizsgáltuk, Brookfield CT3 típusú állományelemző müszer segítségével. TA-RT-KIT típusú alaplapon, TA 44 típusú mérőfejet, valamint TA 9 tü alakú próbatestet használtunk. A mérés paraméterezéséhez (test type: TPA (tü alakú próbatesttel), Compression (TA 44 típusú fejjel), target type: distance, tigger load: 4,0 g, test speed: $1 \mathrm{~mm} / \mathrm{s}$, target value: $10,0 \mathrm{~mm}$ ) alkalmaztunk. A vizsgálati eredményeket a tü behatolásához szükséges erő adta g-ban kifejezve, TA 44 típusú mérőfejjel mért gyümölcsök húskeménységét kg/ $\mathrm{cm}^{2}$ értékben adtuk meg. Az eredményeket a TexturePro CT VI.2 Build 9. szoftverrel értékeltük ki. A TA 9-es tü alakú próbatesttel végzett mérések során a húskeménységen kívül meg tudtuk határozni az adhéziós erőt, a kohéziós erőt, valamint a rágósságot is.

\subsubsection{Vizoldható szárazanyag-tartalom meghatározás}

A gyümölcsök kipréselt levéből a vízoldható szárazanyag tartalmat Atago Palette PR-101 típusú digitális refraktométerrel, a Codex Alimentarius 3-1-558/93 elöírás szerint mértük meg. Az eredményeket Brix ${ }^{\circ}$ - ban határoztuk meg.

\subsection{Kajszifajták kémiai tulajdonságainak vizsgálata}

A titrálható savtartalmat a friss gyümölcsminták levéböl határoztuk meg, míg a többi vizsgálathoz a fagyasztott mintákat használtuk.

\subsubsection{Titrálható savtartalom meghatározása}

A kajsziminták titrálható savtartalmát az MSZ EN 12147:1998 magyar szabvány alapján határoztuk meg. $10 \mathrm{~cm}^{3}$ kajszi levet tízszeresére hígítottunk desztillált vizet használva, fenolftalein indikátort adtunk hozzá, majd 0,1 $\mathrm{N}$ nátrium-hidroxid $(\mathrm{NaOH})$ oldattal rózsaszín 
átcsapásig titráltuk. Az összes savtartalmat almasav egyenértékben határoztuk meg a következö képlet segítségével:

Titrálható $\operatorname{sav}(\%)=\frac{\mathrm{NaOH} \text { fogyás }(\mathrm{cm} 3) \times \mathrm{NaOH} \text { faktor } \mathrm{x} \text { almasav egyenérték x higítás x } 100}{\text { bemért minta mennyisége }(\mathrm{cm} 3)}$

\subsubsection{Cukorfrakciók meghatározása}

A cukorfrakciók meghatározása HPLC müszerrel történt a Gyümölcstermö Növények Tanszék HPLC laboratóriumában.

Mintaelökészítés:

A gyümölcsminták húsából turmixolt homogén pépet fagyasztva, $-25^{\circ} \mathrm{C}$-on tároltuk. A mérés napján a mintákat kiolvasztottuk, s a kiolvadt mintákból 1000 ml-t kimértünk Eppendorf csőbe. Ezt követően a mintákat Hettich Mikro $22 \mathrm{R}$ ultracentrifugával $4{ }^{\circ} \mathrm{C}$-on, 15000 fordulat/perc fordulatszámon lecentrifugáltuk, majd a felülúszót $0,45 \mu \mathrm{m}$ pórusátmérőjü Millipore Siringe Filter Unit SLHN-13 szürővel szürtük, majd ezt követően analizáltuk a mintákat HPLC berendezés segítségével.

Vegyszerek:

Standardként analitikai tisztaságú szacharózt (CAS szám: [57-50-1]), glükózt (CAS szám: [5099-7], fruktózt (CAS szám: [57-48-7]), és szorbitolt (CAS szám: [57-48-7]) használtunk. A standardokat a Sigma Aldrich Chemical Kft-től vásároltuk meg. Oldószerként Millex MILLIQ víztisztító berendezéssel előállított tiszta vizet használtunk. A standardokat vízben $0,01 \mathrm{~g} / 50 \mathrm{ml}$ koncentrációban oldottuk fel, s ezek ötvenszeres hígítását használtuk fel standardként.

HPLC berendezés:

Az analíziseket WATERS HPLC müszer segítségével (Waters Corporation, 34 Maple street Milford MA 01757 USA) végeztük. A berendezés összetétele a következő volt: 2414 Refractive Index Detector, 1525 Binary HPLC Pumpa, Colonna termosztát 717plus automata injektor és in line degasser. A berendezés vezérlését EMPOWER ${ }^{\circledR}$ TM 2 szoftver végezte. A kromatográfiás szétválasztás $90{ }^{\circ} \mathrm{C}$-os körülmények között, Waters Sugar-Pak I oszlopon (300 mm x 6,5 mm ID) történt. Az oszlop előtt in line szürő került beszerelésre. A mozgó fázis víz volt, melyben literenként $50 \mathrm{mg}$ Ca EDTA-t (Calcium disodium ethylene diamine tetraacetate) oldottunk fel. Az áramlási sebességet $0,5 \mathrm{~cm}^{3} /$ perc állítottuk be, így az oszlopon $450 \pm 20$ psi nyomás alakult ki. Az injektált minta mennyisége $20 \mu \mathrm{l}$ volt, a detektálás időtartalma pedig 30 perc volt. A retenciós idő: szacharóz 8,6 perc, glükóz 10,3 perc, fruktóz 12,2 perc, szorbitol 17,1 perc. 


\subsubsection{Savfrakciók meghatározása}

A mintaelökészítés a 3.6.2.-ban leírtak szerint történt. Standardként analitikai tisztaságú almasav (CAS szám: [97-67-6], borostyánkősav (CAS szám: [110-15-6], és citromsavat (CAS szám: [7792-9]) használtunk. A standardokat a Sigma Aldrich Chemical Kft-től vásároltuk meg. Oldószerként MilliQ vizet használtunk. A standardokat 0,01 g / $50 \mathrm{ml}$ koncentrációban oldottuk fel, s ezek ötvenszeres hígítását használtuk fel standarként.

A berendezés összetétele hasonló volt a cukor meghatározásnál használttal, azzal a különbséggel, hogy a savfrakciók detektálása 2487 Dual Absorbanciae UV/VIS Detektor segítségével történt. A szerves savak szétválasztását Shodex RSpak KC-811 (Showa Denko America, Inc., 420 Lexington Ave, Suite 2335A -new York, NY 10170) oszlopon történt, amely elé előtét oszlopot helyeztünk. A mozgó fázis $0,1 \%$ foszforsavat tartalmazó MilliQ víz volt. Az áramlási sebesség 1

$\mathrm{cm}^{3} /$ perc volt, ekkor az oszlopon a nyomás $600 \pm 25$ psi volt. Az injektálás mintánként $20 \mu 1$, a futásidő 15 perc volt. A detektálást $220 \mathrm{~nm}$ hullámhosszon végeztük. A standardok retenciós ideje: citromsav 7,1 perc, almasav 7,9 perc, borostyánkősav 9,1 percnek adódott.

\subsection{4. Összes fenoltartalom meghatározása}

A spektrofotometriás méréseket (polifenol, ß-karotin-tartalom) a Gyümölcstermő Növények Tanszék gyümölcsanalitikai laboratóriumában végeztük. Az összes fenoltartalmat Singleton és Rossi (1965) módszerével határoztuk meg, galluszsavra vonatkoztatva.

Galluszsavra kalibrációs görbét készítettünk. A felolvadt, turmixolt gyümölcspépet Hettich EBA 21 laboratóriumi centrifugával 15000 fordulatszámon centrifugáltuk. A felülúszóból $0,5 \mathrm{~cm}^{3}$ mintát kimértünk, hozzáadtunk $25 \mathrm{~cm}^{3}$ desztillált vizet és $2,5 \mathrm{~cm}^{3}$ FolinCiocalteu's reagenst. 30 másodperc eltelte után, de még 8 perc eltelte előtt $7,5 \mathrm{~cm}^{3} 20 \%$-os $\mathrm{Na}_{2} \mathrm{CO}_{3}$ oldatot adunk hozzá. Az elkészített mintákat 2 órán át állni hagytuk, majd spektrofotométer (Hitachi U-2800A) segítségével az oldatok abszorbanciáját 765 nm-en megmértük. A spektrofotométerben a mintával szemben vak oldatot helyeztünk el. Az összes fenoltartalmat a kalibrációs görbe segítségével a mért abszorbanciából határoztuk meg a következő képlet alapján.

Polifenol-tartalom $(\mathrm{mg} / \mathrm{l})=\frac{\mathrm{A}-\mathrm{b}}{\mathrm{a}}$, ahol

A: a 765 nm-es hullámhosszon mért abszorbancia érték

$\mathrm{a}, \mathrm{b}=\mathrm{a}$ kalibrációs görbe paraméterei ( $\mathrm{a}=$ meredekség; $\mathrm{b}=\mathrm{y}$ tengelymetszet $)$ 


\subsection{5. $\beta$-karotin-tartalom meghatározása}

A ß-karotin-tartalom meghatározás a KPKI (Konzervipari Kutató - Fejlesztő és Minőségvizsgáló Kht) módszere alapján történt. A mintákból 1 g-ot mértünk ki, majd $15 \mathrm{~cm}^{3}$ metanollal elkevertük, és sötét helyen 5 percig állni hagytuk. Ezután G4-es üvegszüröre öntöttük, s a metanolt leszivattuk. A szürőn lévő rostokra $20-25 \mathrm{~cm}^{3}$ acetont öntöttünk, miközben üvegbottal kevergettük. Pár percig állni hagytuk, majd leszivattuk, és a színkioldást a rostok teljes elszíntelenedéséig folytattuk $5-5 \mathrm{~cm}^{3}$ aceton adagokkal. A metanolos-acetonos szürletet választótölcsérbe helyeztük, ahol $25-25 \mathrm{~cm}^{3}$ etiléterrel egyesítettük. A fázisok szétválasztásához meleg, tömény sóoldatot használtunk. Miután leengedtük az utolsó vizes fázist, az éteres fázist egy kiskanál vízmentes nátriumszulfátot tartalmazó redős szürőpapíron át $25 \mathrm{~cm}^{3}$ - es mérőlombikba szürtük, majd a lombikot éterrel jelig töltöttük. Az éteres oldat abszorbanciáját $450 \mathrm{~nm}$-en mértük etiléterrel szemben. A karotintartalom meghatározására a következő képletet használtuk:

Karotintartalom $(\mathrm{mg} / \mathrm{kg})=\frac{\mathrm{A} 450 \times \mathrm{V} \mathrm{x} 4}{\mathrm{~m}}$, ahol

$\mathrm{V}$ : az éteres oldat térfogata, $\mathrm{cm}^{3}$

$\mathrm{A}_{450}$ : a 450 nm-en mért abszorbancia

$\mathrm{m}$ : a bemért minta $(\mathrm{g})$

\subsection{Statisztikai értékelési módszerek}

Összehasonlító ANOVA és regressziós modellek:

1. Az eredmények kiértékeléséhez IBM SPSS Statistics 20 programot használtunk. A fagytürési középértéket $\left(\mathrm{LT}_{50}\right)$ lineáris regressziós modell alkalmazásával határoztuk meg, feltételezve, hogy a kapott szigmoid görbének a $20 \%$ és a 80 \% közötti szakasza lineárisnak tekinthető (Gu, 1999).

2. A nyugalmi időszakban mért $\mathrm{LT}_{50}$ értékek alapján a fajták ('Ceglédi bíborkajszi', 'Gönci magyar kajszi', 'Rózsakajszi C.1406') és az évjáratok (2010/2011; 2011/2012; 2012/2013) közötti különbség meghatározására kéttényezős (fajta, év) blokkos elrendezésű ANOVA modellt használtunk, ahol a vizsgálat időpontjai alkották a blokkokat. A fajták csoportosítását fagyérzékenységük alapján hierarchikus klaszteranalízissel végeztük el.

3. A virágzáskori $\mathrm{LT}_{50}$ értékek alapján a (fent felsorolt) fajták és az évjáratok közötti különbség meghatározására kéttényezős (fajta, év) elrendezésű ANOVA modellt futtattunk.

4. A mikrosporogenézis folyamatát szigmoid függvénnyel tudjuk meghatározni, melynek a képlete: 
$Y(X)=100 /\left[1+E X P\left(-s^{*}(X-m)\right)\right]+\varepsilon$

ahol X: a Julianus napban meghatározott dátumot jelöli

m: a görbe inflexiós pontja, amely megegyezik a mediánnal (50\%-os kvantilis)

$\mathrm{s}$ : sebességi tényezö; a görbe meredeksége az $\mathrm{X}=\mathrm{m}$ pontban $\mathrm{s} / 4$

$\varepsilon: 0$ várható értékü, normális eloszlású hibatag

5. A fizikai paraméterek (tömeg, magasság, szélesség, vastagság) alapján a fajták ('Gönci magyar kajszi', 'Sylvercot', 'Pinkcot', 'Goldrich', 'Orange Red', 'Veecot', 'Aurora', 'Bergarouge', 'Budapest', 'Mandulakajszi', 'Harcot', 'Harogem', 'Litoral') és az évjáratok (2011, 2013) összehasonlítását kéttényezős (fajta, év) többváltozós ANOVA (MANOVA) modellel végeztük.

6. A kézi penetrométerrel mért húskeménységi $\left(\mathrm{kg} / \mathrm{cm}^{2}\right)$ értékek segítségével a fizikai paraméternél felsorolt fajták és évjáraton túl a napos és árnyékos oldalon kapott értékeket is összehasonlítottuk kéttényezős (fajta, év) MANOVA modellel, ahol a két változót a napos és árnyékos oldalon mért értékek alkották. A szóráshomogenitás sérülése miatt az adatokon gyöktranszformációt végeztünk.

7. A húskeménység mérésére alkalmas módszerek (húskeménység mérése kézi penetrométerrel, Texture analyser müszerrel, két különböző fejjel: TA44 és TA9 próbatestekkel) összehasonlítását a Pearson-féle korrelációs együttható segítségével végeztük.

8. Az állománymérő műszerrel végzett vizsgálatok négy paraméterértékre terjedtek ki (húskeménység, adhéziós erő, kohéziós erő és rágási energiaszükséglet) egy év (2013) adatai kilenc fajta ('Litoral', 'Pinkcot', 'Sylvercot', 'Goldrich', 'Bergarouge', 'Harcot', 'Orange Red', 'Veecot', 'Gönci magyar kajszi') bevonásával. A fajták összehasonlítására egytényezős MANOVA modellt futtattunk, ahol a két változót a napos és árnyékos oldalon mért értékek alkották.

9. A vízoldható szárazanyagtartalom értékeket a fizikai paraméternél felsorolt fajtákra és évjáratokra szintén összehasonlítottuk a napos és árnyékos oldalon kapott értékek alapján. Ismét kéttényezős (fajta, év) MANOVA modellt használtunk, ahol a két változót a napos és árnyékos oldalon mért értékek alkották. A szóráshomogenitás sérülése miatt az adatokon gyöktranszformációt végeztünk.

10. A cukor- és savösszetevők alakulását két évben (2011, 2013) 7 fajtánál ('Gönci magyar kajszi', 'Goldrich', 'Pinkcot', 'Sylvercot', 'Veecot', 'Harcot', 'Harogem') vizsgáltuk. A fajták összehasonlítására kéttényezős (fajta, év) többváltozós MANOVA modellt használtunk. 
11. A B-karotin-tartalom és a polifenol-tartalom fajták, illetve évjáratok szerinti összehasonlítására kéttényezős (fajta: 'Pinkcot', 'Sylvercot', 'Veecot', 'Gönci magyar kajszi', év: 2011, 2013) ANOVA modelleket használtunk.

12. A vízoldható szárazanyag-tartalom $\left(\mathrm{Brix}^{\circ}\right)$ és húskeménység $\left(\mathrm{kg} / \mathrm{cm}^{2}\right)$ összefüggését nemlineáris regressziós modellekkel írtuk le. Kétféle modellt alkalmaztunk, a telítődési, illetve a logisztikus modellt az alábbi alakokban:

(a) Telítődési modell: $y=p_{1}+p_{2}\left(1-\exp \left(-p_{3}^{*} x\right)\right)+\varepsilon$, ahol

$x$ a független változó $\left(\right.$ Brix $\left.^{\circ}\right)$

$p_{1}$ a függvény értéke az $x=0$ pontban

$p_{2}$ a telítődési érték és $p_{1}$ különbsége

$p_{3}$ a görbe meredekségi tényezője

$\varepsilon$ normális eloszlású, 0 várható értékű hibatag.

(b) Logisztikus modell: $y=p_{1}+\left(p_{2}-p_{1}\right) /\left(1+\exp \left(-p_{3} *\left(x-p_{4}\right)\right)\right)+\varepsilon$, ahol

$x$ a független változó $\left(\mathrm{Brix}^{\circ}\right)$

$p_{1}$ a modell mínusz végtelenben vett határértéke

$p_{2}$ a telítődési érték

$p_{3}$ a görbe meredekségi tényezője

$p_{4}$ az inflexiós pont helye

$\varepsilon$ normális eloszlású, 0 várható értékű hibatag.

A mikrosporogenézis folyamatának kiértékeléséhez a vizsgálati eredményeinkre regressziós modellt illesztettünk, becsültük a modellre vonatkozó ANOVA F-értékeit, az együtthatókra vonatkozó t-értékeket, a magyarázott varianciát $\left(\mathrm{R}^{2}\right)$, valamint az F-, $\mathrm{t}$ - és $\mathrm{R}^{2}$ értékekhez tartozó szignifikanciaszinteket. A statisztikai elemzés során az átmenet időpontjának a szigmoid görbék 50\%-os értékhez tartozó kvantilisét tekintettük, a virágzáskezdet fázisában pedig az 5\%-os értékhez tartozó kvantilist vettük figyelembe, mivel az ültetvényben azt tekintjük a virágzáskezdet napjának, amikor a virágok 5\%-a kinyílt.

Először a három vizsgálati évet hasonlítottuk össze, figyelembe véve a különböző fenológiai stádiumok kezdeti időpontját. A fenológiai stádiumok elkülönítésére ismétléses ANOVA vizsgálatot alkalmaztunk. Szignifikanciaszintjeik alapján értékeltük a nem magyarázott varianciahányadot (Wilks-féle lambda). Ahol szükséges volt, Greenhouse-Geisser korrekciót végeztünk a szfericitási feltétel sérülése esetén. Elvégeztük a mintákon belüli próbákat, majd a 
Bonferroni-féle páronkénti összehasonlítást. A fajták fenológiai sorrendjeinek hasonlóságát a rangszámokon alapuló nemparaméteres Friedman-teszttel mértük össze. Variációs koefficienst (CV) számítottunk a fenológiai fázisok kezdőpontjára, mellyel a fejlődésmenet sebességének évjárati érzékenységét kívántuk kimutatni. Ezeket az értékeket kéttényezős (fajta, fenológiai stádium) ANOVA-val hasonlítottuk össze. Kéttényezős (fajta, fenológiai stádium) véletlen blokkos elrendezésű varianciaanalízissel vizsgáltuk a fenológiai stádiumok sebességi tényezőit (s), ahol a véletlen faktor az év volt. Abban az esetben, ha a normalitás sérült, inverz transzformációt alkalmaztunk.

A MANOVA eredmények esetén közöljük a Wilk-féle lambda értékeket, melyek a nem magyarázott varianciahányadot adják meg, illetve ezek F-próba alapján meghatározott szignifikanciáját is feltüntetjük. (A Wilk-féle lambda értéke minél kisebb, annál nagyobb a vizsgált faktorok (pl. fajta, év) által magyarázott varianciahányad.) Szignifikáns MANOVA-teszt eredmény esetén változónkénti ANOVA-tesztet is végeztünk.

A rezidumok normalitását Kolmogorov-Smirnov-, Shapiro-Wilk- és d'Agostino-teszttel (D’Agostino et al., 1990), a szórások homogenitását Levene-teszttel ellenőriztük. A szórások azonossága esetén a post hoc vizsgálatot Tukey-teszttel, ha a szóráshomogenitás enyhén sérült, akkor Games-Howell-teszttel végeztük.

Az ábrákon a post hoc vizsgálatok eredményeit betűvel jeleztük. A betűk abc sorrendje a nagyság szerinti sorrendet jelzi, a különböző betük a szignifikánsan különböző csoportokra vonatkoznak $(\mathrm{p}<0,05)$. 


\section{EREDMÉNYEK}

\subsection{Kajszifajták virágrügyeinek és virágainak fagytürése a mesterséges fagyasztásos kísérletek eredményi alapján}

\subsubsection{A virágrügyek fagykárosodása a téli nyugalmi idöszakban}

A három évjárat kísérleti eredményeit egymás után elemezzük. Minden vizsgálati időpontban meghatároztuk a genotípusra jellemző fagytürési középértékeket (LT 50 értékek) (1. modell). Ez az a hőmérséklet, amely az adott időpontban 50\%-os fagykárosodást idézett elő.

2010/11 telén a standard fajtákat 13 alkalommal, a külföldi fajtákat pedig 7 alkalommal vizsgáltuk. A standard fajták kísérleti eredményei közül a 2011. január 2-i időpontot emeltünk ki részletes bemutatás céljából, a tél folyamán e vizsgálati napon mutatkozott a legnagyobb fagytürés. A választott kezelési hőmérsékletekhez tartozó eredményekből (7. táblázat) jól látható, hogy $-19{ }^{\circ} \mathrm{C}$-on minhárom fajta kis mértékben károsodott, ezzel szemben $-25{ }^{\circ} \mathrm{C}$-on a 'Ceglédi bíborkajszi' és a 'Gönci magyar kajszi' csaknem 100\%-ban károsodott, a 'Rózsakajszi C. 1406' kiemelkedő fagytürőképességgel rendelkezett. Ez utóbbi $\mathrm{LT}_{50}$ értéke ebben az időpontban -23,3 ${ }^{\circ} \mathrm{C}$ volt. A legfagyérzékenyebb a három standard fajta közül a 'Ceglédi bíborkajszi' volt, a statisztikai adatok alapján megállapított $\mathrm{LT}_{50}$ értéke $-20,8{ }^{\circ} \mathrm{C}$. Ebben az időpontban a legfagytürőbb genotípus $2,5^{\circ} \mathrm{C}$-kal alacsonyabb lehülést is elviselt, mint a fagyérzékeny.

7. táblázat: A standard fajták fagykárosodásának mértéke (a hat minta átlaga) és a lineáris regresszióval becsült $\mathrm{LT}_{50}$ értékei 2011. január 2-án különböző kezelési hőmérsékleteken (n=6)

\begin{tabular}{|c|c|c|c|c|c|}
\hline \multirow{2}{*}{ Fajta } & \multicolumn{4}{|c|}{ Kezelési hőmérséklet $\left({ }^{\circ} \mathrm{C}\right)$} & \multirow{2}{*}{ LT50 érték } \\
\hline & -19 & -21 & -23 & -25 & \\
\hline \multicolumn{6}{|c|}{ Fagykár mértéke (\%) } \\
\hline $\mathrm{CB}$ & 15,3 & 55,1 & 90,7 & 99,5 & $-20,8$ \\
\hline GÖ & 9,1 & 39,6 & 78 & 99,5 & $-21,5$ \\
\hline RÓ & 3,6 & 17,1 & 41,7 & 77,1 & $-23,3$ \\
\hline
\end{tabular}


A nyugalmi időszakban rendszeresen végzett mesterséges fagyasztásos kísérleteink eredményei alapján ábrázoltuk a standard fajták virágrügyeinek fagyállóság-változását 2010/11 telén (4. ábra). A grafikonon ábrázolt $\mathrm{LT}_{50}$ értékeket a M.2.4. táblázatban közöltük. Minden vizsgálati időpontban a 'Ceglédi bíborkajszi’ bizonyult a legfagyérzékenyebbnek, a 'Rózsakajszi C. 1406' pedig a legfagytürőbbnek a három fajta közül. 2010. szeptember 1-én a legfagyérzékenyebb és a legfagytüröbb genotípus között $1,7{ }^{\circ} \mathrm{C}$ különbség volt, 2011. január 2án ez 2,5 ${ }^{\circ} \mathrm{C}$-ra növekedett, majd 2011. március 21 -re ez mindössze $1,5^{\circ} \mathrm{C}$-ra mérséklödött. A fajták maximális fagytürése január elején alakult ki, ezután fokozatosan csökkent.

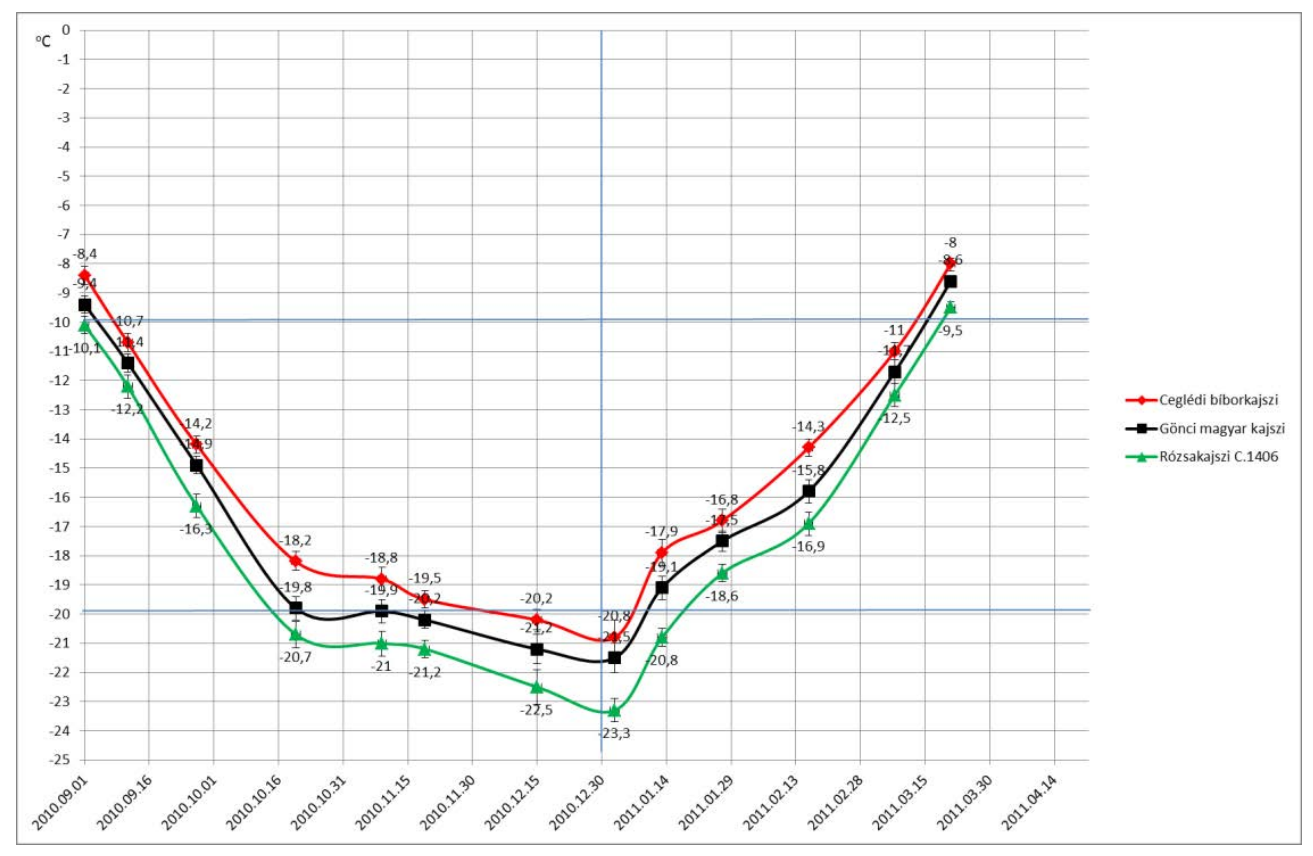

4. ábra: A standard fajták virágrügyeinek fagytürési középértékei $\left(\mathrm{LT}_{50}\right)$ 2010/11 telén, a mesterséges fagyasztásos kísérletek eredményei alapján

A külföldi fajták eredményei közül a 2010. november 18-i eredményeket részletezzük (8. táblázat). A 'Sylvercot' három különböző alanyon (myrobalan, Missuri, C 29) is megtalálható Móron, így módunk volt az alanyhatást is közölni. Ebben a vizsgálati időpontban míg $-19{ }^{\circ} \mathrm{C}$-on a myrobalan alanyon 63,2\%-ban, a Missuri alanyon 53,7\%-ban, a C29-es alanyon 54,5\%-ban, addig $-23{ }^{\circ} \mathrm{C}$-on mind a három alanyon $100 \%$-ban károsodott a 'Sylvercot' fajta virágrügyei. A 'Sylred' fajta esetében a $-19{ }^{\circ} \mathrm{C}$-os kezelési hőmérséklet 33,7\%-os, addig a 'Laycot' fajta esetében 76,1\%-os fagykárt okozott a rügyekben. $-23{ }^{\circ} \mathrm{C}$-on a 'Sylvercot' fajtához hasonlóan a többi külföldi fajta is 100 \%-ban elfagyott. A különböző alanyokon a 'Sylvercot' fajta fagytürési középértékei a következőképpen alakultak: myrobalan alanyon $-18,3{ }^{\circ} \mathrm{C}$, Missuri alanyon $-18,8$ ${ }^{\circ} \mathrm{C}$, C29-es alanyon $-18,6{ }^{\circ} \mathrm{C}$. Az eredményekből jól kitünik, hogy a három alany közül a Missuri alanyon volt a legjobb a fajta fagytürőképessége, míg myrobalan alanyon volt a leggyengébb, viszont mindössze $0,5^{\circ} \mathrm{C}$ különbség volt a két alany között, tehát nagyon hasonlóan alakult a 
'Sylvercot' fajta fagytüröképessége a három különböző alanyon. A legjobb fagytürési középértéke $\left(-19,5^{\circ} \mathrm{C}\right)$ a 'Sylred' fajtának volt, míg a legrosszabb fagytürési középértékkel ($17,9^{\circ} \mathrm{C}$ ) a 'Laycot' fajta rendelkezett. A 'Sylred' és a 'Laycot' fajta között 1,6 ${ }^{\circ} \mathrm{C}$ különbség volt. A ‘Goldrich' és a 'Pisana' fajták LT $_{50}$ értékei közel megegyezőek voltak.

8. táblázat: Külföldi kajszifajták fagykárosodásának mértéke (a hat minta átlaga) és a lineáris regresszióval becsült $\mathrm{LT}_{50}$ értékei 2010. november 18-án különböző kezelési hőmérsékleteken $(\mathrm{n}=6)$

\begin{tabular}{|c|c|c|c|c|c|}
\hline \multirow{2}{*}{ Fajta } & \multicolumn{4}{|c|}{ Kezelési hőmérséklet $\left({ }^{\circ} \mathrm{C}\right)$} & \multirow{2}{*}{ LT50 érték } \\
\hline & -17 & -19 & -21 & -23 & \\
\hline \multicolumn{6}{|c|}{ A fagykár mértéke (\%) } \\
\hline $\begin{array}{c}\text { Sylvercot } \\
\text { (myrobalan) }\end{array}$ & 25,3 & 63,2 & 99 & 100 & $-18,3$ \\
\hline $\begin{array}{l}\text { Sylvercot } \\
\text { (Missuri) }\end{array}$ & 17,6 & 53,7 & 96,4 & 100 & $-18,8$ \\
\hline $\begin{array}{l}\text { Sylvercot } \\
\text { (C29) }\end{array}$ & 18,6 & 54,5 & 100 & 100 & $-18,6$ \\
\hline Sylred & 13,1 & 33,7 & 93,8 & 100 & $-19,5$ \\
\hline Pinkcot & 10,2 & 73,3 & 97,5 & 100 & $-18,3$ \\
\hline Goldrich & 13,8 & 55,8 & 94 & 100 & $-18,8$ \\
\hline Pisana & 12,2 & 44,1 & 93 & 100 & -19 \\
\hline Laycot & 29,9 & 76,1 & 100 & 100 & $-17,9$ \\
\hline
\end{tabular}

Az 5. ábrán a 'Sylvercot' fagytürési középértékeit a teljes 2010/11 téli időszakban ábrázoltuk. A grafikonokon szereplö $\mathrm{LT}_{50}$ értékeket az M.2.5. táblázatban közöljük. A fajta faggyal szembeni ellenállóságának mértéke nagyon hasonlóan alakult mind a három alanyon. A legnagyobb különbséget 2011. 02. 21-én mértük, ekkor $1,7^{\circ} \mathrm{C}$ különbség volt a myrobalan és a C29-es alanyon lévő 'Sylvercot' fajta között, a többi vizsgálati időpontban csak nagyon kis különbséget tudtunk kimutatni. 


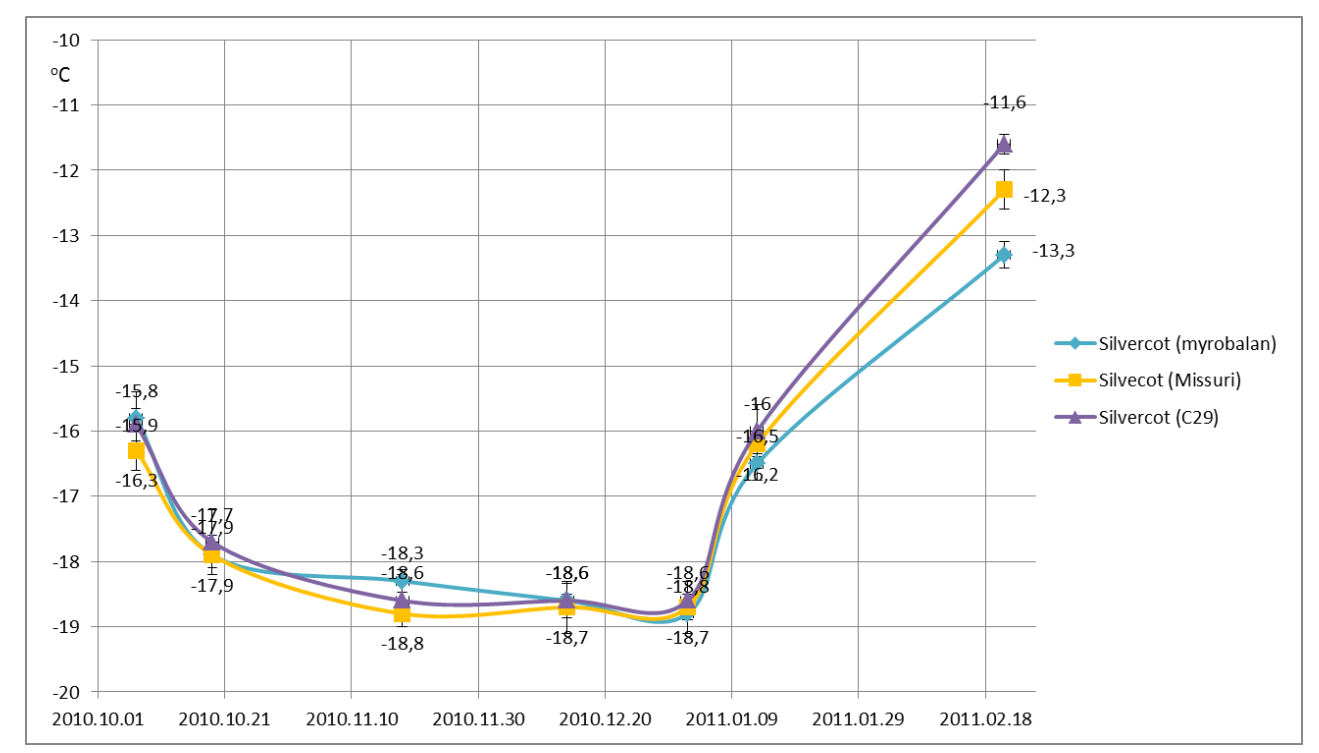

5. ábra: A 'Sylvercot' fajta virágrügyeinek fagytürési középértékei $\left(\mathrm{LT}_{50}\right)$ három különböző alanyon 2010/11 telén, a mesterséges fagyasztásos kísérletek eredményei alapján

A 6. ábrán a hat külföldi fajta fagytürési középértékeit hasonlítottuk össze a kísérletünkben legfagyérzékenyebbnek számító 'Ceglédi bíborkajszi', valamint a legfagytürőbbnek számító ‘Rózsakajszi C. 1406’ fajtákkal (M.2.4, M.2.5.). A ‘Sylvercot’ fajtánál a myrobalan alanyon lévőt választottuk ki, mert a többi külföldi fajta is myrobalan alanyon volt. A hat külföldi kajszifajtát majdnem minden vizsgálati időpontban fagyérzékenyebbnek találtuk a 'Ceglédi bíborkajszi' fajtához képest. A külföldi fajták közül a 'Laycot' bizonyult a legfagyérzékenyebbnek.

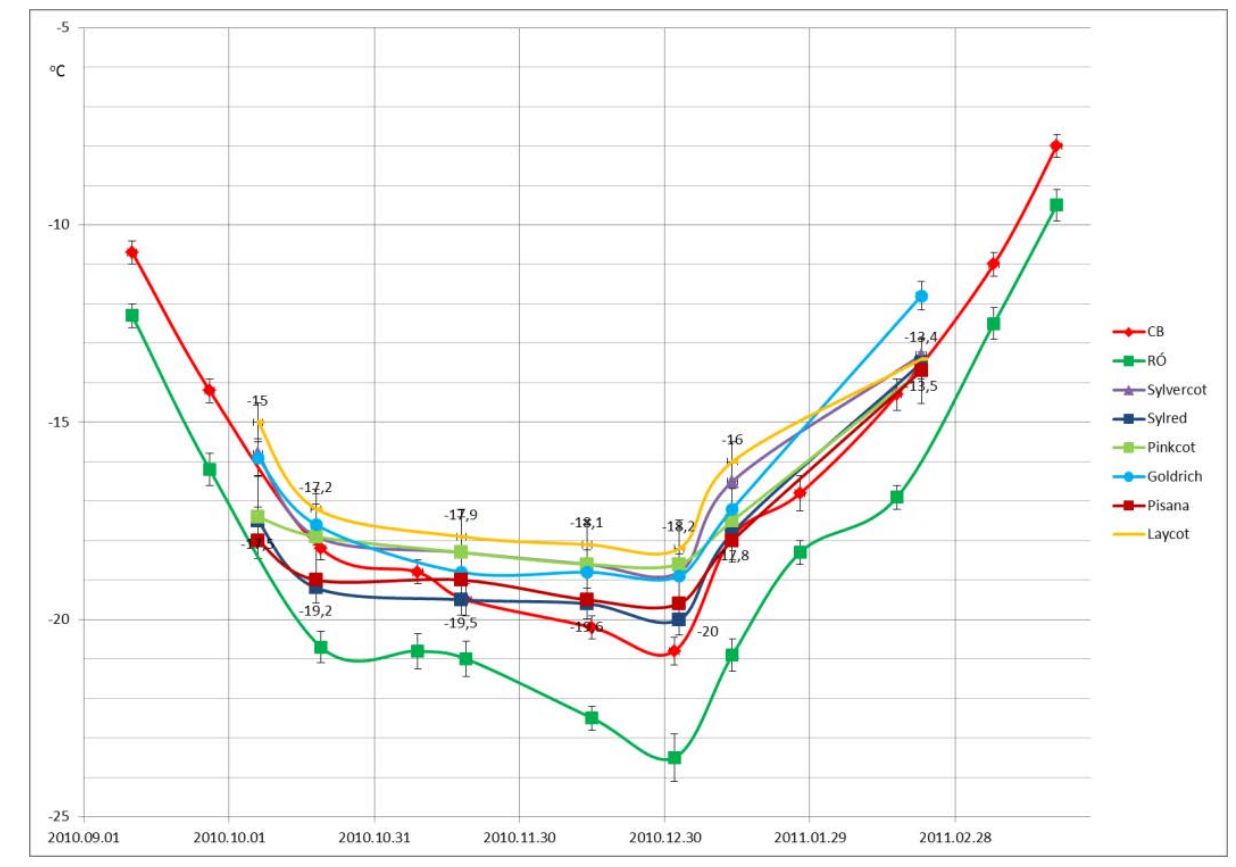

6. ábra: Külföldi kajszifajták virágrügyeinek fagytürési középértékei $\left(\mathrm{LT}_{50}\right)$ 2010/11 telén, a mesterséges fagyasztásos kísérletek eredményei alapján, összehasonlítva két standard fajta vizsgálati eredményeivel 
A 7. ábrán a standard fajták közül a legfagyérzékenyebb ('Ceglédi bíborkajszi’) és a legfagytürőbb ('Rózsakajszi C.1406’) virágrügyeinek fagytürési középértékeit ábrázoltuk ebben az évjáratban, összehasonlítva a környezet napi maximum és minimum hömérsékletének alakulásával. Az ábrán a virágzási időszak egy-egy jellemző adatát is feltüntettük annak érdekében, hogy a folyamat egésze áttekinthető legyen, de a virágzási időszak kísérleti eredményeit külön alfejezetben elemezzük részletesen.

2010 őszén fokozatosan csökkent a hőmérséklet, és korán beköszöntöttek az első fagyok, az október 8. és november 1. között eltelt 25 nap közül 18 esetében a reggeli órákban fagypont alatti hőmérsékleteket mért a méröállomás. Ezután egy felmelegedés következett, enyhe reggeli és magas napközbeni hőmérsékletekkel, majd november 24. után csökkent tartósan fagypont alá a minimum hőmérséklet. A virágrügyek edződésének második szakasza ezután következett be. A hideg időszak december 29 -ig tartott, amikor $-15,3{ }^{\circ} \mathrm{C}$ volt a reggeli órákban. Az áttelelő szervek edződési folyamatát hátráltatta, hogy decemberben a hideg időszakot rövid enyhe periódusok szakították meg. Így valószínüleg nem tudták elérni a virágrügyek a genotípusra jellemző maximális fagyállóságukat. 2011. január 2-án a 'Rózsakajszi C.1406' fajta virágrügyeinek fagytürési középértéke vizsgálati eredményeink szerint $-23,3{ }^{\circ} \mathrm{C}$ volt. 2011. január elején erös felmelegedés következett be, ami január 20-ig tartott. Ennek hatására a virágrügyek fagytürö képessége gyorsan elkezdett csökkenni, és a január 13-i mintavételi időpontban a 'Rózsakajszi C.1406' virágrügyeinek fagytürési középértéke már csak $-20,8{ }^{\circ} \mathrm{C}$ volt. A tél második felében nagyon ingadozó volt a hőmérséklet, az enyhébb időszakokban gyorsan, a hidegebb időszakokban lassabban veszítették el az áttelelő szervek a fagytürő képességüket. A virágzási időszakhoz közeledve egyre kisebb volt a hajlamuk a hideghez való hozzáedződésre. Jól mutatják ezt a februári és márciusi vizsgálati eredményeink. A február 24. és március 9. közötti hideg időszakban, amikor több reggelen is $-10{ }^{\circ} \mathrm{C}$ alatt volt a hőmérséklet, az áttelelő szervek fagytürése gyors ütemben csökkent. Szerencsére nem voltak jelentős fagykárt okozó hőmérsékletek. 


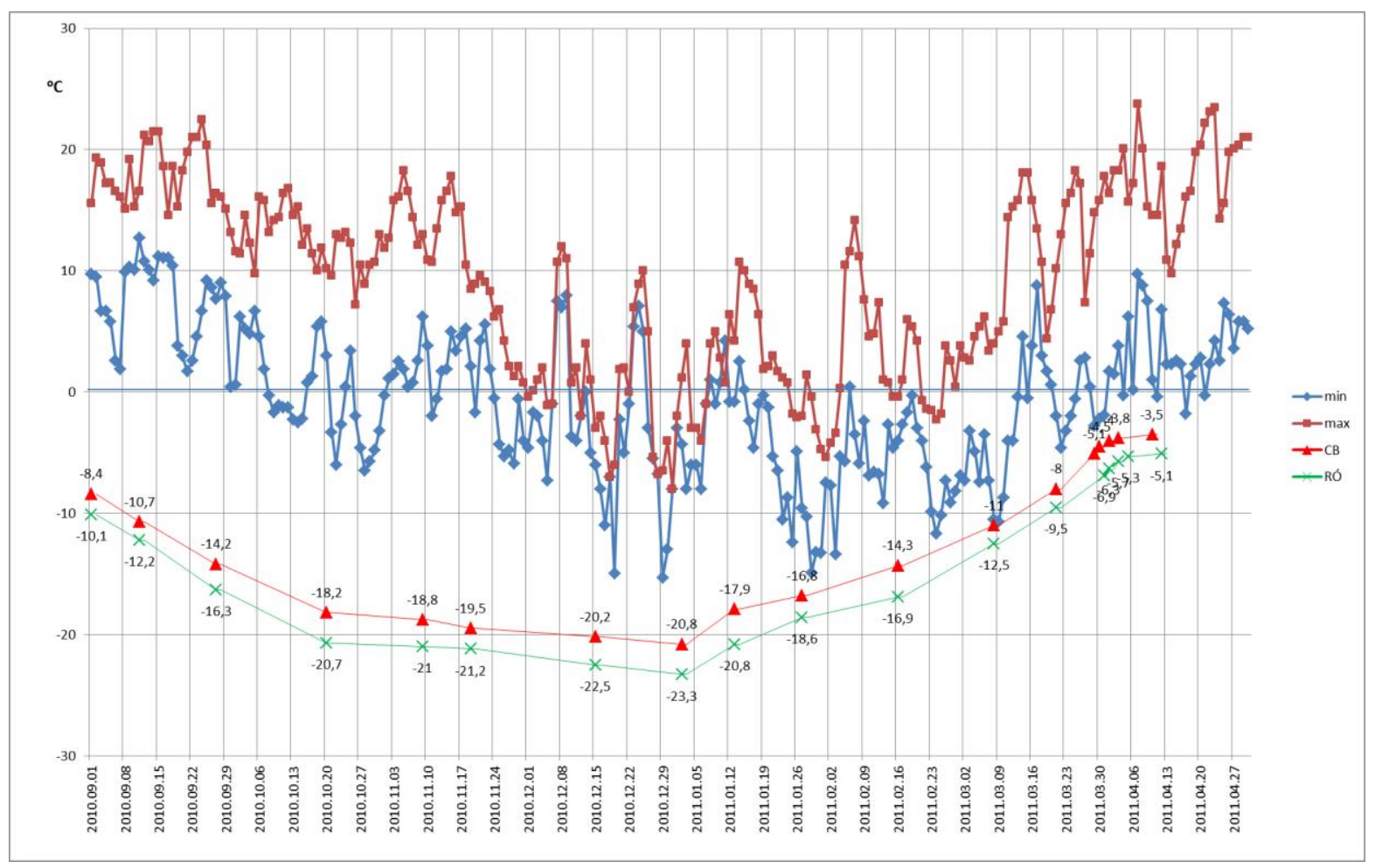

7. ábra: Két standard fajta virágrügyeinek fagytürési középértékei $\left(\mathrm{LT}_{50}\right)$ 2010/11 telén, valamint a napi minimum és maximum hőmérsékletek alakulása

2011/12 telén a standard fajtákat 11 alkalommal, a külföldi fajtákat pedig négy alkalommal vizsgáltuk. A standard fajták kísérleti eredményei közül ismét egyet emeltünk ki részletes bemutatás céljából, a 2011. december 22-i időpontot (9. táblázat). Ebben az évjáratban a tél folyamán e méréskor voltak a legfagytürőbbek a fajták. A standard fajták $-19{ }^{\circ} \mathrm{C}$-on kis mértékben károsodtak. $-25{ }^{\circ} \mathrm{C}$-on a 'Ceglédi bíborkajszi' és a 'Gönci magyar kajszi' fajták teljes mértékben elfagytak, míg a 'Rózsakajszi C. 1406' fajta átlagosan 85,2\%-ban károsodott. Az előző évhez hasonlóan kiemelkedő fagytűrőképességgel rendelkezett a 'Rózsakajszi C. 1406', melynek $\mathrm{LT}_{50}$ értéke $-23{ }^{\circ} \mathrm{C}$ volt. A legfagyérzékenyebbnek ismét a 'Ceglédi bíborkajszi' bizonyult, a statisztikai adatok alapján megállapított $\mathrm{LT}_{50}$ értéke $-20,5{ }^{\circ} \mathrm{C}$ volt. Ebben az időpontban a legfagytürőbb genotípus $2,5{ }^{\circ} \mathrm{C}-\mathrm{kal}$ alacsonyabb lehülést is elviselt, mint a fagyérzékeny genotípus a tavalyi évi vizsgálati eredményekhez hasonlóan. 
9. táblázat: A standard fajták fagykárosodásának mértéke (a hat minta átlaga) és a lineáris regresszióval becsült $\mathrm{LT}_{50}$ értékei 2011. december 22-én különböző kezelési hömérsékleteken $(n=6)$

\begin{tabular}{|c|c|c|c|c|c|}
\hline \multirow{2}{*}{ Fajta } & \multicolumn{4}{|c|}{ Kezelési hőmérséklet $\left({ }^{\circ} \mathbf{C}\right)$} & \multirow{2}{*}{ LT50 érték } \\
\hline & -19 & -21 & -23 & -25 & \\
\hline \multicolumn{6}{|c|}{ Fagykár mértéke (\%) } \\
\hline $\mathrm{CB}$ & 11,3 & 61,6 & 94,3 & 100 & $-20,5$ \\
\hline GÖ & 9,4 & 43,2 & 78 & 100 & $-21,4$ \\
\hline RÓ & 3,9 & 19,5 & 52,1 & 85,2 & -23 \\
\hline
\end{tabular}

A 8. ábrán a 2011/12-es évjáratban figyelhetjük meg a három standard kajszifajta fagytürési középértékeinek alakulását. A grafikonon ábrázolt $\mathrm{LT}_{50}$ értékek lineáris regresszióval becsült eredményeit a M.2.6. táblázatban közöljük. Minden vizsgálati időpontban az előző évhez hasonlóan a 'Ceglédi bíborkajszi' fajta bizonyult a legfagyérzékenyebbnek, a 'Rózsakajszi C. 1406' pedig a legfagytürőbbnek a három standard fajta közül. 2011. szeptember 1-én a legfagyérzékenyebb és a legfagytürőbb genotípus között $3{ }^{\circ} \mathrm{C}$ különbség volt, 2011. december 22-én ez $2,5{ }^{\circ} \mathrm{C}$-ra csökkent, majd 2012. március 12-én $2,1{ }^{\circ} \mathrm{C}$ volt. A fajták maximális fagytürése december második felében alakult ki, ezután fokozatosan csökkent.

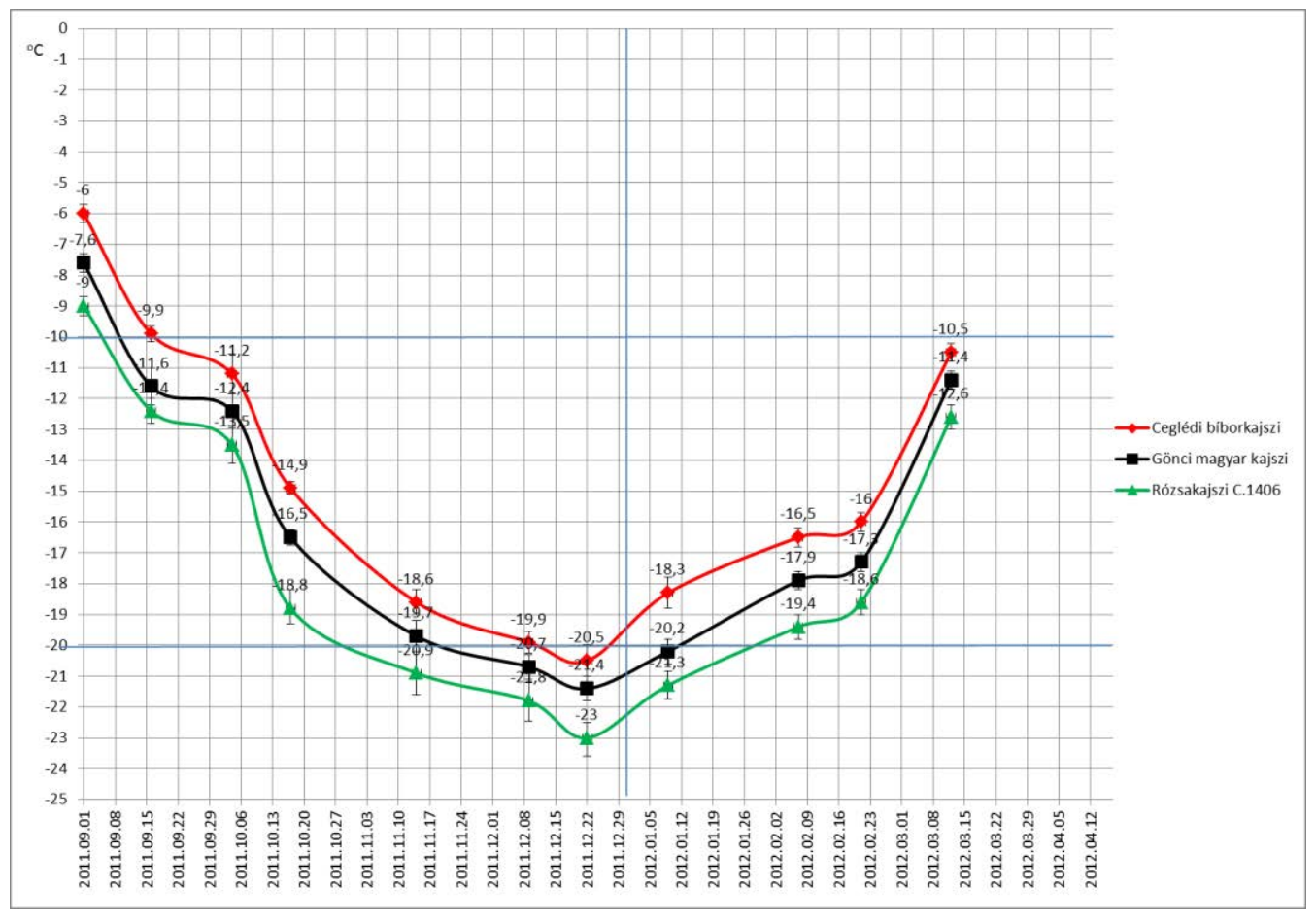

8. ábra: A standard fajták virágrügyeinek fagytürési középértékei $\left(\mathrm{LT}_{50}\right)$ 2011/12 telén, a mesterséges fagyasztásos kísérletek eredményei alapján 
2011/12 telén a vizsgálati időpontok közül 4 alkalommal teszteltük a külföldi kajszifajták fagytürőképességét. A vizsgálatba vont fajták közül hármat már az előző évben is vizsgáltuk. A vizsgálati időpontok közül a 2012. január 9-i eredményeket részletezzük (10. táblázat). A vizsgálat alapján megállapítható, hogy míg a 'Goldrich' esetében a $-19{ }^{\circ} \mathrm{C}$-os kezelési hömérséklet 26,7\%-os, addig a 'Pincot' esetében 66,3\%-os fagykárt okozott a rügyekben. -25 ${ }^{\circ} \mathrm{C}$-on mind a 3 fajta közel 100\%-ban elfagyott. A legjobb fagytürési középértéke $\left(-20,6{ }^{\circ} \mathrm{C}\right)$ a 'Goldrich' fajtának volt, míg a legrosszabb fagytürési középértékkel $\left(-18,1^{\circ} \mathrm{C}\right)$ a 'Pinkcot' rendelkezett. A 'Goldrich' és a 'Pinkcot' fagytürési középértékei között $2,5{ }^{\circ} \mathrm{C}$ különbség volt ebben a vizsgálati időpontban.

10. táblázat: Külföldi kajszifajták fagykárosodásának mértéke (a hat minta átlaga) és a lineáris regresszióval becsült $\mathrm{LT}_{50}$ értékei 2012. január 9-én különböző kezelési hőmérsékleteken $(\mathrm{n}=6)$

\begin{tabular}{ccccccc}
\hline \multirow{2}{*}{ Fajta } & \multicolumn{7}{c}{ Kezelési hőmérséklet $\left({ }^{\circ} \mathbf{C}\right)$} & \multirow{2}{*}{ L T50 érték } \\
\cline { 2 - 5 } & $\mathbf{- 1 7}$ & $\mathbf{- 1 9}$ & $\mathbf{- 2 1}$ & $\mathbf{- 2 3}$ & $\mathbf{- 2 5}$ & \\
\hline A fagykár mértéke (\%) \\
\hline Goldrich & 5 & 26,7 & 56,8 & 84 & 99,5 & $-20,6$ \\
Pinkcot & 25,8 & 66,3 & 90,3 & 98,3 & 100 & $-18,1$ \\
Sylvercot & 19,3 & 57,1 & 80,3 & 94,1 & 100 & $-18,6$ \\
Orange Red & 10,2 & 20,5 & 55,1 & 87,3 & 96,2 & $-20,7$ \\
Sweet Red & 43,3 & 83,6 & 96,6 & 100 & 100 & $-17,3$ \\
Veecot & 0 & 16,7 & 63,7 & 89,5 & 100 & $-20,4$ \\
\hline
\end{tabular}

2012. január 9-én, a 'Veecot' esetében a -19 ${ }^{\circ} \mathrm{C}$-os kezelési hömérséklet 16,7\%-os, a 'Sweet Red' esetében ezzel szemben $83,6 \%$-os fagykárt okozott a rügyekben. $-25{ }^{\circ} \mathrm{C}$-on mind a három ezévbe először vizsgált fajta közel 100\%-ban elfagyott. A legjobb fagytürési középértéke $\left(-20,7^{\circ} \mathrm{C}\right)$ az 'Orange Red' fajtának volt, míg a legrosszabb fagytürési középértékkel $\left(-17,3^{\circ} \mathrm{C}\right)$ a 'Sweet Red' rendelkezett. Az utóbbi két genotípus fagytürési középértékei között $3,4{ }^{\circ} \mathrm{C}$ különbség volt ebben a vizsgálati időpontban.

A 9. ábrán mutatjuk be a hat külföldi kajszifajta LT $_{50}$ értékeinek alakulását a 2011/12-es téli nyugalmi időszak folyamán összehasonlítva a három standard fajtáéval. A grafikonokon jelölt $\mathrm{LT}_{50}$ értékeket a M.2.7. táblázatban közöltük. Majdnem minden időpontban a 'Sweet Red' bizonyult a legfagyérzékenyebbnek, míg a 'Veecot' a legfagytürőbbnek. A fajták maximális fagytürése 2011. december első felében volt mérhetö, ekkor $3,1{ }^{\circ} \mathrm{C}$ különbség volt a legfagyérzékenyebb és legfagytürőbb genotípus között, és ettől az időponttól kezdve fokozatosan 
veszítették el fagytürési képességüket a fajták. A 'Sweet Red' és a 'Pinkcot' fagyérzékenyebbnek bizonyultak a fagyérzékeny csoportot képviselő 'Ceglédi bíborkajszi' fajtához képest. A 'Sylvercot', 'Goldrich' és az 'Orange Red' fagyérzékenyebbnek bizonyultak a közepes fagytürőképességü ‘Gönci magyar kajszi’-nál, de a ‘Ceglédi bíborkajszi’-étól jobb volt a fagytürésük. A 'Veecot' fagytürése hasonló volt a 'Gönci magyar kajszi'-éhoz.

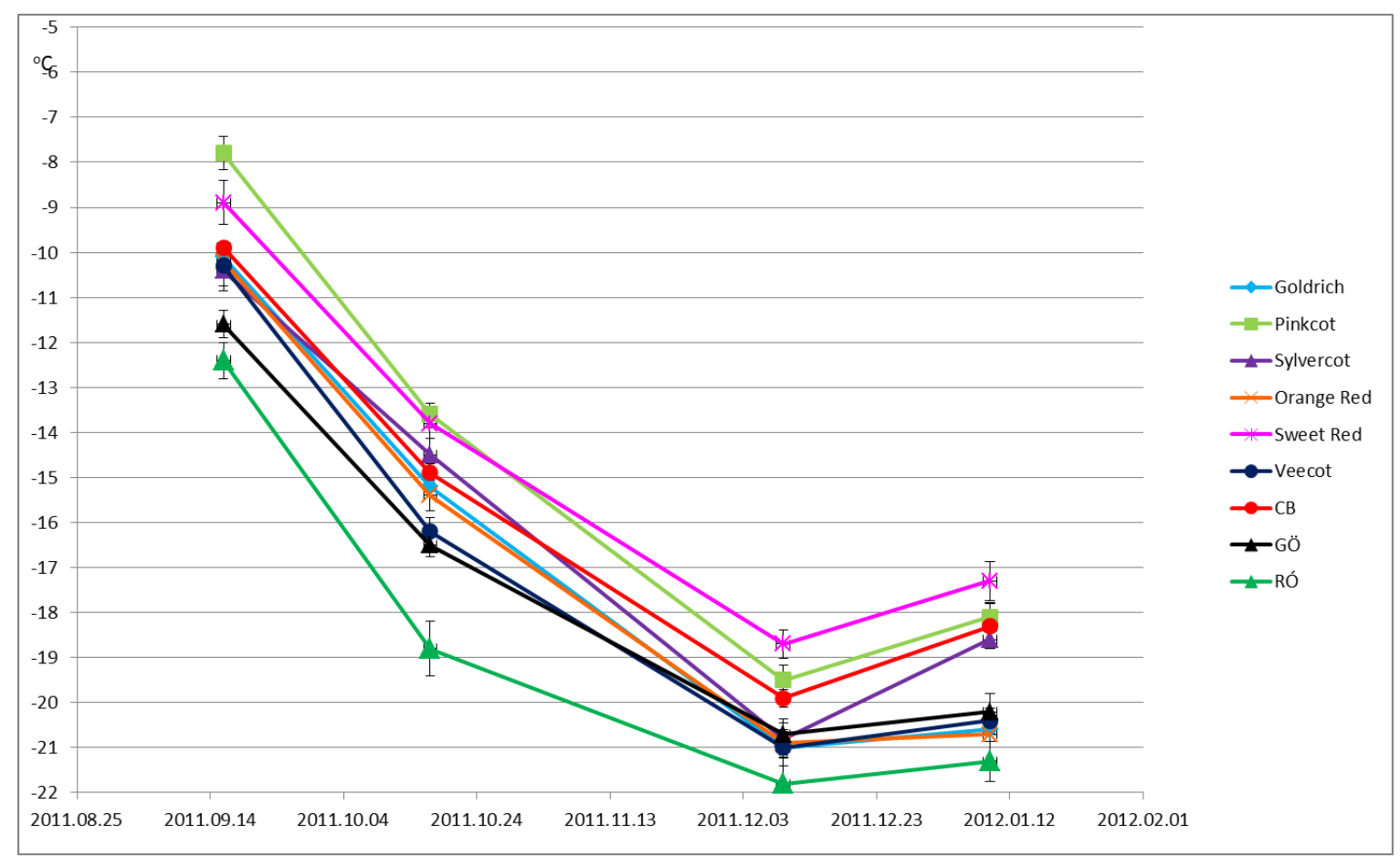

9. ábra: Hat új fajta virágrügyeinek fagytürési középértékei $\left(\mathrm{LT}_{50}\right)$ 2011/12 telén, a mesterséges fagyasztásos kísérletek eredményei alapján, összehasonlítva a három standard fajta vizsgálati eredményeivel

A 10. ábrán a korábbi évhez hasonlóan a legfagyérzékenyebb ('Ceglédi bíborkajszi’) és a legfagytürőbb ('Rózsakajszi C.1406') standard fajta virágrügyeinek LT $_{50}$ értékeit ábrázoltuk a 2011/12-es évjáratban, összehasonlítva a környezet napi maximum és minimum hőmérsékletének alakulásával. 2011 őszén fokozatosan csökkent a hőmérséklet és a korábbi évhez hasonlóan ebben az évjáratban is korán beköszöntöttek az első fagyok, az október 14. és november 4. között eltelt 22 nap közül 13 esetében a reggeli órákban fagypont alatti hőmérsékleteket mutatott a mérőállomás. Ezután egy pár napos rövid felmelegedés következett be, majd november 9-e után csökkent tartósan fagypont alá a minimum hőmérséklet. A virágrügyek edződésének második szakasza ezután következett be, de az enyhe időjárás következtében valószínüleg nem tudott teljes mértékben lejátszódni. Így valószínüleg ebben az évjáratban sem tudták elérni a virágrügyek a genotípusra jellemző maximális fagyállóságukat. A hideg időszak január 1-éig tartott, amikor $-8,2^{\circ} \mathrm{C}$ volt a reggeli órákban. 2011. december 22-én a 'Rózsakajszi C.1406' fajta virágrügyeinek fagytürési középértéke vizsgálati eredményeink 
szerint $-23{ }^{\circ} \mathrm{C}$ volt. Ezután a felmelegedés hatására a virágrügyek fagytürő képessége fokozatosan csökkent, és a január 9-i mintavételi időpontban a 'Rózsakajszi C.1406' fajta virágrügyeinek fagytürési középértéke már csak $-21,3{ }^{\circ} \mathrm{C}$ volt. A tél második felében nagyon ingadozó volt a hőmérséklet. 2012. február 10-én $-18,7{ }^{\circ} \mathrm{C}$ volt az ültetvényben, ennek következtében komoly fagykárosodást szenvedtek a kajszifajták.

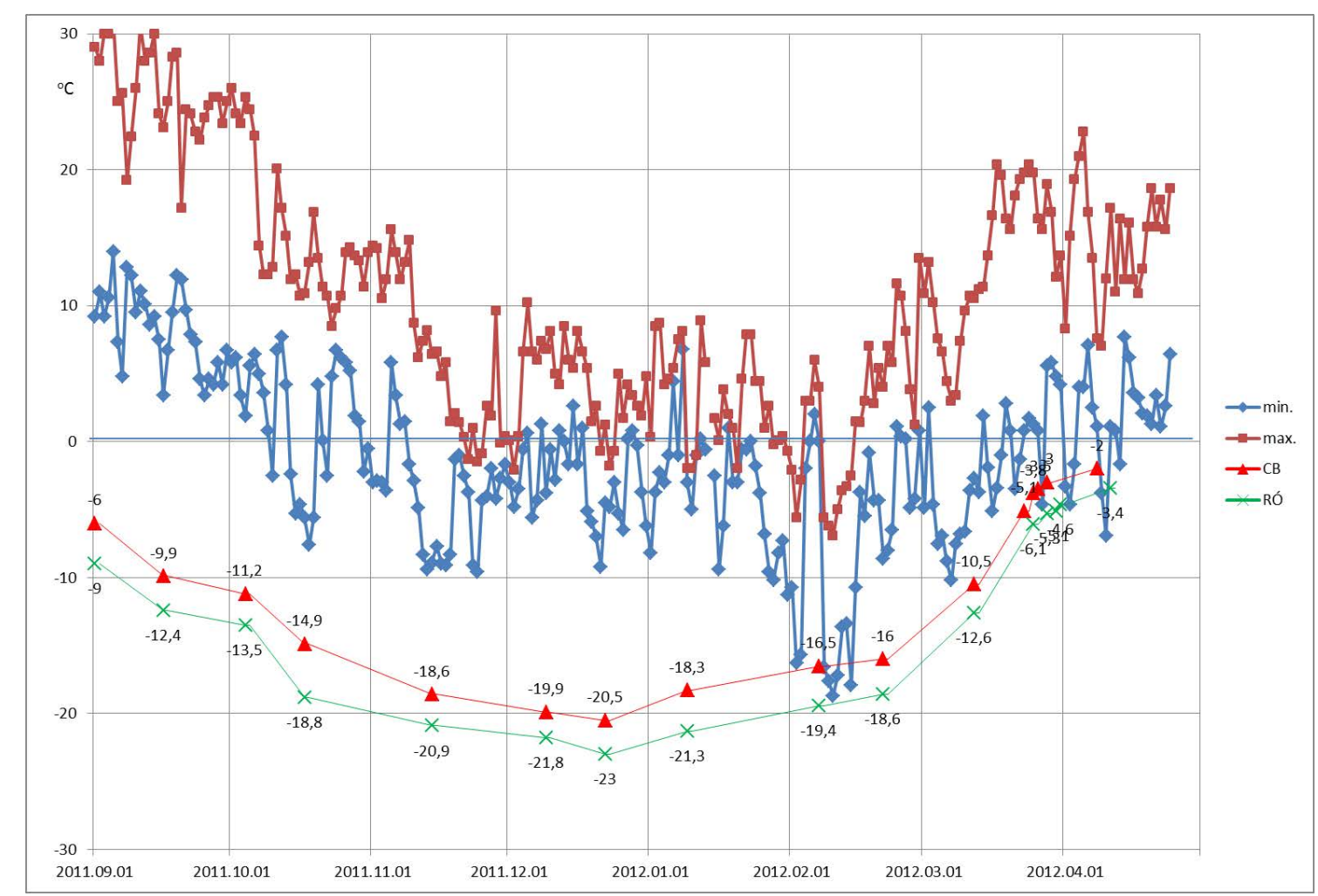

10. ábra: A napi minimum és maximum hőmérsékletek alakulása, valamint két standard fajta virágrügyeinek fagytürési középértékei $\left(\mathrm{LT}_{50}\right)$ 2011/12 telén

A 2012-2013-as nyugalmi időszak vizsgálati eredményei következnek. 2012/13 telén a standard fajtákat 13 alkalommal, a külföldi fajtákat pedig öt alkalommal vizsgáltuk. A standard fajták kísérleti eredményei közül a 2013. január 1-i időpontot elemezzük részletesebben, mert a tél folyamán e méréskor voltak a legfagytürőbbek a fajták (11. táblázat). A $-19{ }^{\circ} \mathrm{C}$-os kezelési hőmérsékleten a standard fajták csak kis mértékben károsodtak, $-25{ }^{\circ} \mathrm{C}$-on a 'Ceglédi bíborkajszi' átlagosan 100\%-ban, a 'Gönci magyar kajszi' átlagosan 88,1\%-ban, míg a 'Rózsakajszi C. 1406' átlagosan 72,3\%-ban károsodott. Kiemelkedő fagytürőképességgel rendelkezett a 'Rózsakajszi C. 1406', melynek $\mathrm{LT}_{50}$ értéke $-22,9{ }^{\circ} \mathrm{C}$ volt. A legfagyérzékenyebb a három standard fajta közül a 'Ceglédi bíborkajszi' volt, a statisztikai adatok alapján megállapított $\mathrm{LT}_{50}$ értéke $-20,2{ }^{\circ} \mathrm{C}$ volt. Ebben az időpontban a legfagytürőbb genotípus $2,7{ }^{\circ} \mathrm{C}$ kal alacsonyabb lehülést is elviselt, mint a fagyérzékeny genotípus. 
11. táblázat: A standard fajták fagykárosodásának mértéke (a hat minta átlaga) és a lineáris regresszióval becsült $\mathrm{LT}_{50}$ értékei 2013. január 1-én különböző kezelési hőmérsékleteken (n=6).

\begin{tabular}{|c|c|c|c|c|c|}
\hline \multirow{2}{*}{ Fajta } & \multicolumn{4}{|c|}{ Kezelési hőmérséklet $\left({ }^{\circ} \mathbf{C}\right)$} & \multirow{2}{*}{ LT50 érték } \\
\hline & -19 & -21 & -23 & -25 & \\
\hline \multicolumn{6}{|c|}{ Fagykár mértéke (\%) } \\
\hline $\mathrm{CB}$ & 22,7 & 67,5 & 93,2 & 100 & $-20,2$ \\
\hline GÖ & 14,03 & 42,1 & 69,5 & 88,1 & $-21,7$ \\
\hline RÓ & 12,3 & 28,1 & 51,9 & 72,3 & $-22,9$ \\
\hline
\end{tabular}

A téli nyugalmi időszakban rendszeresen végzett mesterséges fagyasztásos kísérleteink eredményei alapján ábrázoltuk a standard fajták virágrügyeinek fagyállóságának változását 2012/13 telén (11. ábra). A grafikonon ábrázolt LT $_{50}$ értékeket lineáris regresszióval határoztuk meg, melyek eredményeit a M.2.8. táblázatban közöljük. Minden vizsgálati időpontban a 'Ceglédi bíborkajszi' bizonyult a legfagyérzékenyebbnek, a 'Rózsakajszi C. 1406' pedig a legfagytürőbbnek. 2012. szeptember 1-én a legfagyérzékenyebb és a legfagytürőbb genotípus között $1,3{ }^{\circ} \mathrm{C}$ különbség volt, 2013. január 1-én ez 2,7 ${ }^{\circ} \mathrm{C}$-ra növekedett, majd 2013. március 26án $2,9{ }^{\circ} \mathrm{C}$ volt. A fajták maximális fagytürése január elején alakult ki, ezután fokozatosan csökkent.

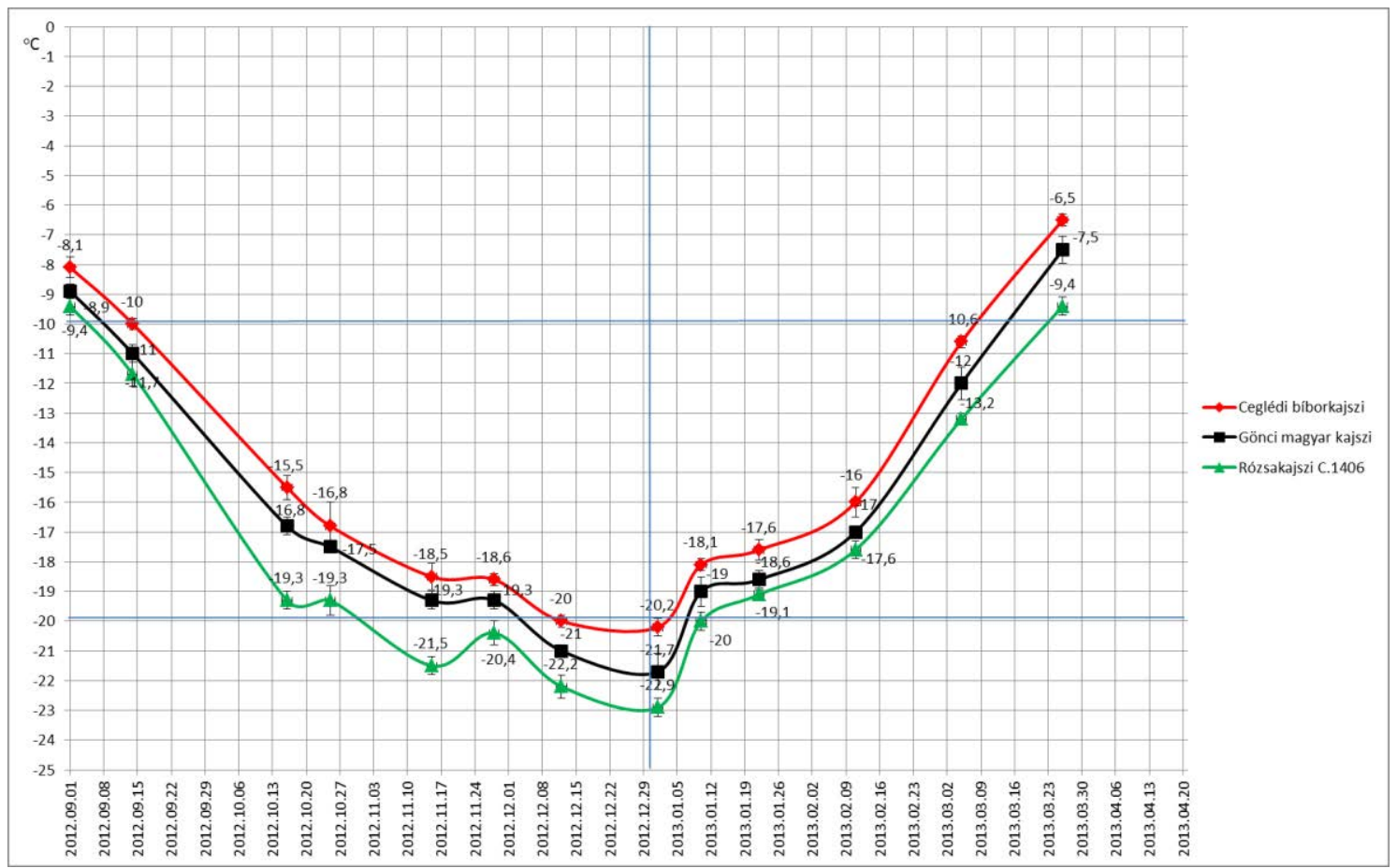

11. ábra: A standard fajták virágrügyeinek fagytürési középértékei $\left(\mathrm{LT}_{50}\right)$ 2012/2013 telén, a mesterséges kísérletek eredményei alapján 
2012/13 telén a vizsgálati időpontok közül öt alkalommal teszteltük a külföldi fajták fagytürőképességét (12. táblázat). A vizsgáltba vont fajták közül a három, már a két előző évben is vizsgált külföldi kajszifajtát jellemezzük elsőként. A vizsgálati időpontok közül a 2013. február 11-i eredményeket részletezzük. A vizsgálat alapján megállapítható, hogy míg a 'Goldrich' esetében a $-15^{\circ} \mathrm{C}$-os kezelési hőmérséklet átlagosan 12,1\%-os, addig a 'Pinkcot' és 'Sylvercot' esetében átlagosan $26 \%$ körüli fagykárt okozott a rügyekben. $-21{ }^{\circ} \mathrm{C}$-on mind a három fajta közel 100\%-ban elfagyott. A legjobb fagytürési középértéke $\left(-16,7^{\circ} \mathrm{C}\right)$ a 'Goldrich' fajtának volt, míg a 'Pinkcot' $\left(-15,8^{\circ} \mathrm{C}\right)$ és a 'Sylvercot' $\left(-15,9^{\circ} \mathrm{C}\right)$ közel azonos $\mathrm{LT}_{50}$ értékekkel rendelkezett.

12. táblázat: Külföldi kajszifajták fagykárosodásának mértéke (a hat minta átlaga) és a lineáris regresszióval becsült $\mathrm{LT}_{50}$ értékei 2013. február 11-én különböző kezelési hőmérsékleteken $(n=6)$.

\begin{tabular}{|c|c|c|c|c|c|}
\hline \multirow{2}{*}{ Fajta } & \multicolumn{4}{|c|}{ Kezelési hőmérséklet $\left({ }^{\circ} \mathrm{C}\right)$} & \multirow{2}{*}{ LT50 érték } \\
\hline & -15 & -17 & -19 & -21 & \\
\hline \multicolumn{6}{|c|}{ A fagykár mértéke (\%) } \\
\hline Goldrich & 12,1 & 65 & 92,2 & 96,1 & $-16,7$ \\
\hline Pinkcot & 26,2 & 84,3 & 94,7 & 100 & $-15,8$ \\
\hline Sylvercot & 26,1 & 81,2 & 94,7 & 100 & $-15,9$ \\
\hline Aurora & 39,2 & 94,1 & 98,8 & 100 & $-15,4$ \\
\hline Bergarouge & 6 & 46,8 & 76,4 & 87,8 & $-17,4$ \\
\hline Harlayne & 3 & 21,1 & 66,1 & 79,7 & $-18,3$ \\
\hline
\end{tabular}

A három, csak ebben az évjáratban vizsgált külföldi kajszifajta fagyérzékenységének 2013. február 11-i eredményéből kitünik, hogy míg a 'Harlayne' esetében a $-15{ }^{\circ} \mathrm{C}$-os kezelési hőmérséklet 3\%-os, addig a 'Aurora' esetében 39,2\%-os fagykárt okozott a rügyekben. $-25{ }^{\circ} \mathrm{C}$ on az 'Aurora' esetében már 100\%-os volt a fagykár mértéke, addig a 'Harlayne’ fajtánál 79,7\%os. A legjobb fagytürési középértéke $\left(-18,3^{\circ} \mathrm{C}\right)$ a 'Harlayne' fajtának volt, míg a legrosszabb fagytürési középértékkel $\left(-15,4^{\circ} \mathrm{C}\right)$ az 'Aurora' rendelkezett. Az utóbbi két genotípus fagytürési középértékei között $2,9^{\circ} \mathrm{C}$ különbség volt ebben a vizsgálati időpontban.

A 12. ábrán a hat külföldi fajta fagytürési középértékeit hasonlítottuk össze a három standard fajtáéval 2012/13 telén. A grafikonokon jelölt LT $_{50}$ értékeket a M.2.8.-M.2.9. táblázatokban közöljük. Az 'Aurora', a 'Pinkcot' és a 'Sylvercot' fagyérzékenyebbnek bizonyultak a fagyérzékeny csoportot képviselő 'Ceglédi bíborkajszi' fajtához képest. Míg a 
'Goldrich' fajta fagyérzékenyebbnek, a 'Bergarouge' fajta fagytüröbbnek bizonyult a közepes fagytürőképességü 'Gönci magyar kajszi' fajtától. A 'Harlayne' fagytürése az edződési időszak elején rosszabb volt, viszont a téli nyugalmi időszak jelentős részében jobb fagytürési értékeket mutatott a ‘Rózsakajszi C.1406’ fajtához képest.

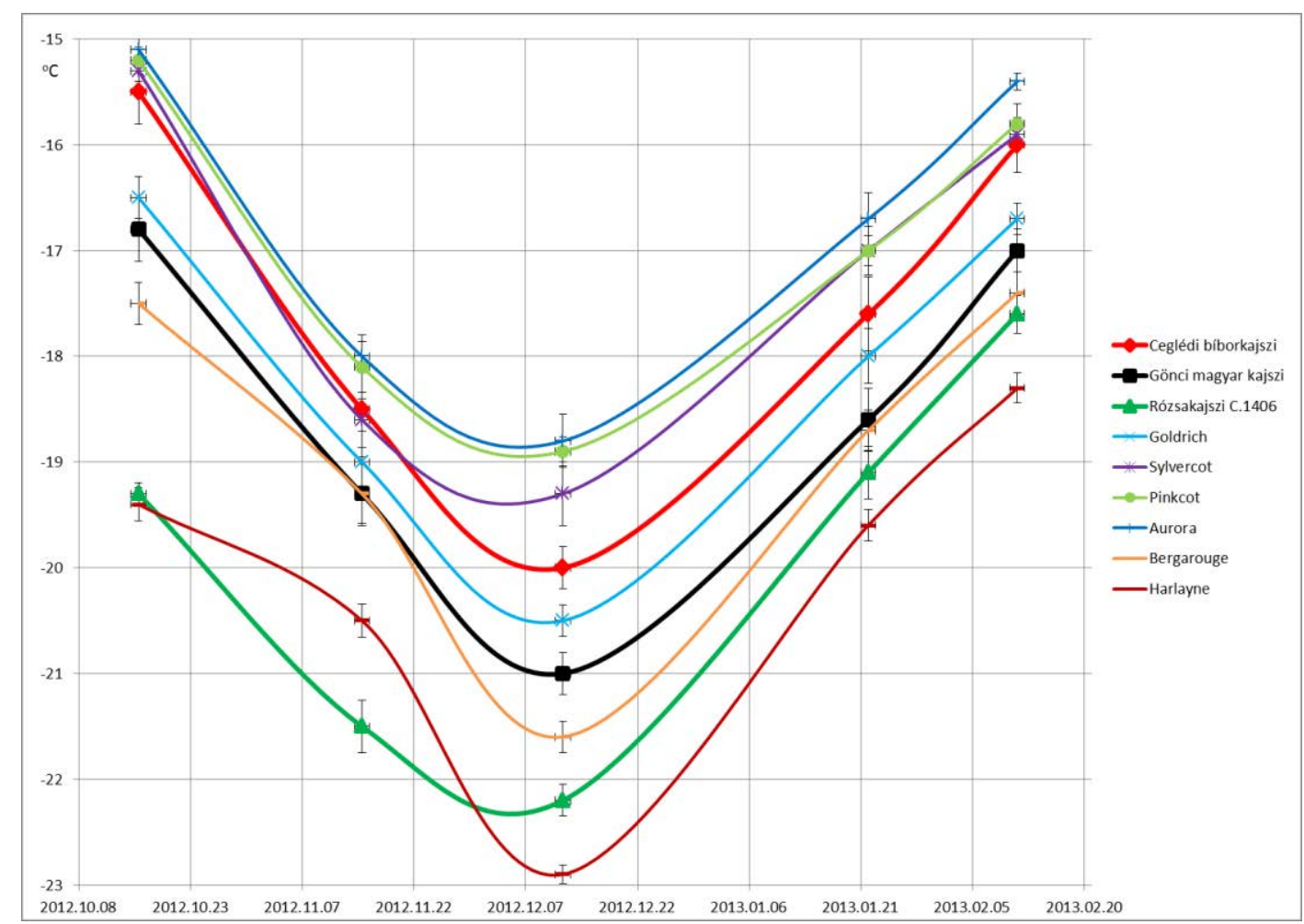

12. ábra: Hat külföldi kajszifajta virágrügyeinek fagytürési középértékei $\left(\mathrm{LT}_{50}\right)$ 2012/2013 telén a mesterséges fagyasztásos kísérletek eredményei alapján, összehasonlítva 3 standard fajta vizsgálati eredményeivel

A 13. ábrán a korábbi évekhez hasonlóan a legfagyérzékenyebb ('Ceglédi bíborkajszi’) és a legfagytürőbb ('Rózsakajszi C.1406') standard fajta virágrügyeinek $\mathrm{LT}_{50}$ értékeit ábrázoltuk a 2012/13-es évjáratban, összehasonlítva a környezet napi maximum és minimum hőmérsékletének alakulásával. 2012 őszén fokozatosan csökkent a hőmérséklet és ebben az évjáratban az első fagyok október végén jelentkeztek, az október 28. és november 20. között eltelt 24 nap közül 14 esetében a reggeli órákban fagypont alatti hőmérsékleteket mutatott a méröállomás. Ezután egy 10 napos rövid felmelegedés következett be, majd 2012. december 1-e után csökkent tartósan fagypont alá a minimum hőmérséklet. A virágrügyek edződésének második szakasza ezután következett be. A tél folyamán a hőmérséklet ritkán csökkent $-10{ }^{\circ} \mathrm{C}$ alá. A hideg időszak január 1-jéig tartott, amikor $-6^{\circ} \mathrm{C}$ volt a reggeli órákban. 2012. január 1-jén a 'Rózsakajszi C.1406' fajta virágrügyeinek fagytürési középértéke vizsgálati eredményeink szerint $-22,9{ }^{\circ} \mathrm{C}$ volt. Ezután a felmelegedés hatására a virágrügyek fagytürő képessége fokozatosan csökkent, és a január 10-i mintavételi időpontban a 'Rózsakajszi C.1406' fajta 
virágrügyeinek fagytürési középértéke már csak $-20{ }^{\circ} \mathrm{C}$ volt. 2013 . március 29 -én $-10,5{ }^{\circ} \mathrm{C}$ volt az ültetvényben, ennek következtében természetes fagykárt szenvedtek a kajszifajták.

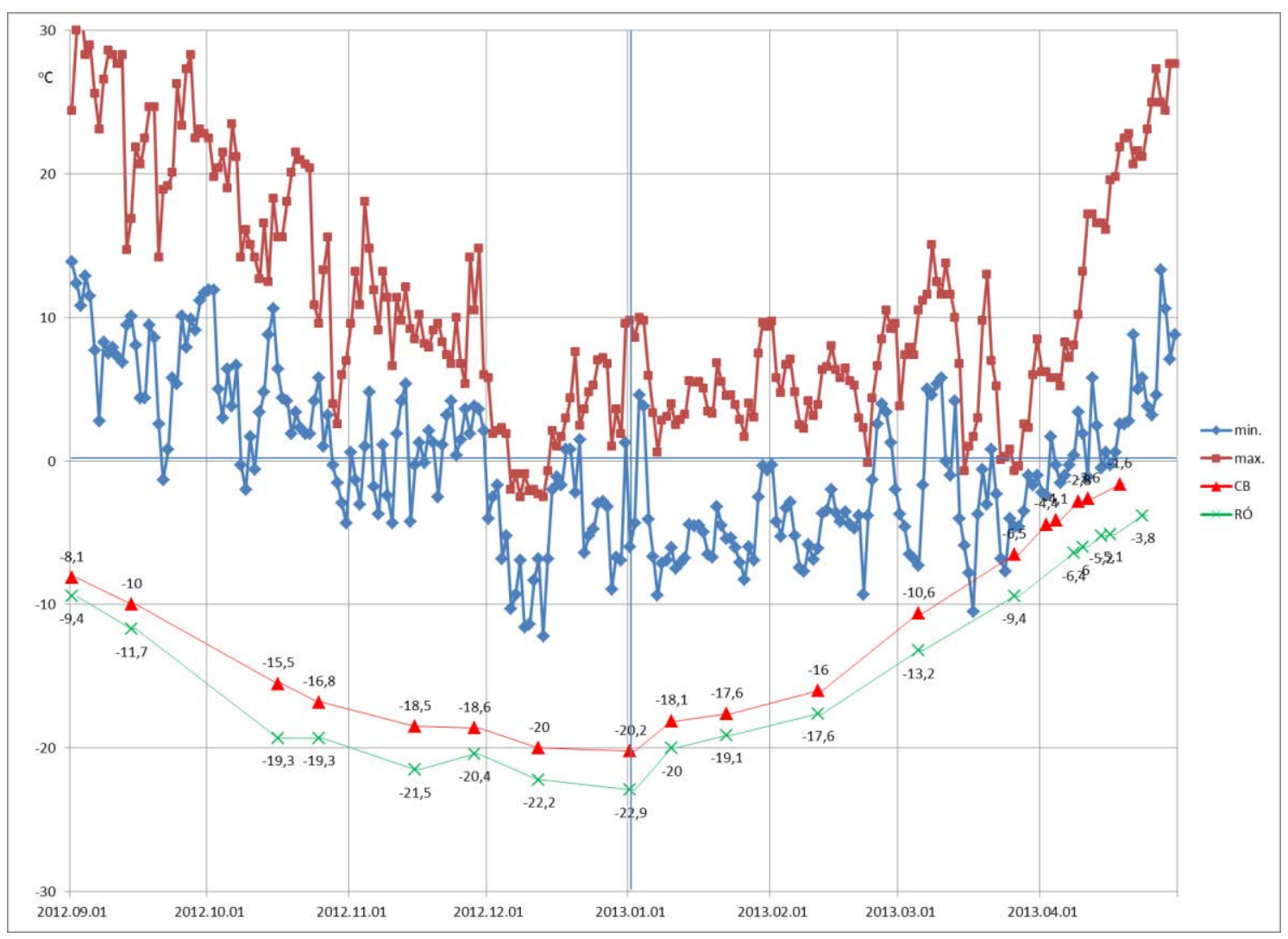

13. ábra: A napi minimum és maximum hőmérsékletek alakulása, valamint 2 standard fajta virágrügyeinek fagytürési középértékei $\left(\mathrm{LT}_{50}\right)$ 2012/2013

\subsubsection{A virágzási idöszakok fagytürési vizsgálatainak eredményei}

Három egymás utáni évben vizsgáltuk három kajszifajta generatív szerveinek fagytürő képességét mesterséges fagyasztásos kísérletekkel. A vizsgálatok során a fagytürést fenológiai fázisonként értékeltük.

A 14. ábra szemlélteti a három standard fajta fagytürési középértékeit a virágzás különböző fenofázisában 2011-ben. A lineáris regresszióval becsült LT $_{50}$ értékeket a M.2.10. táblázatban közöljük. A vizsgálati eredményeink alapján elmondható, hogy a virágzás elörehaladtával csökkent a standard fajták virágainak fagytürőképessége. A 'Ceglédi bíborkajszi' $\mathrm{LT}_{50}$ értéke zárt csészebimbó állapotban $-5,2{ }^{\circ} \mathrm{C}$ volt, a virágzás kezdetén ez az érték $-4{ }^{\circ} \mathrm{C}-\mathrm{ra}$ csökkent, s a virágzás végén már csak $-3,5^{\circ} \mathrm{C}$ volt. A ‘Rózsakajszi C.1406' esetében ezek az értékek jobbak voltak. Zárt csészebimbó állapotban $-7,1^{\circ} \mathrm{C}$-ot is kibírtak a virágok, ez a virágzás kezdetén $-5,7{ }^{\circ} \mathrm{C}$-ra csökkent, a virágzás végén pedig $-5,1{ }^{\circ} \mathrm{C}$ volt ez az érték. A virágzás végén a fagytürő fajta generatív szervei $1,6{ }^{\circ} \mathrm{C}$-al alacsonyabb hőmérsékletet is elviseltek, mint a fagyérzékeny fajtáé. 


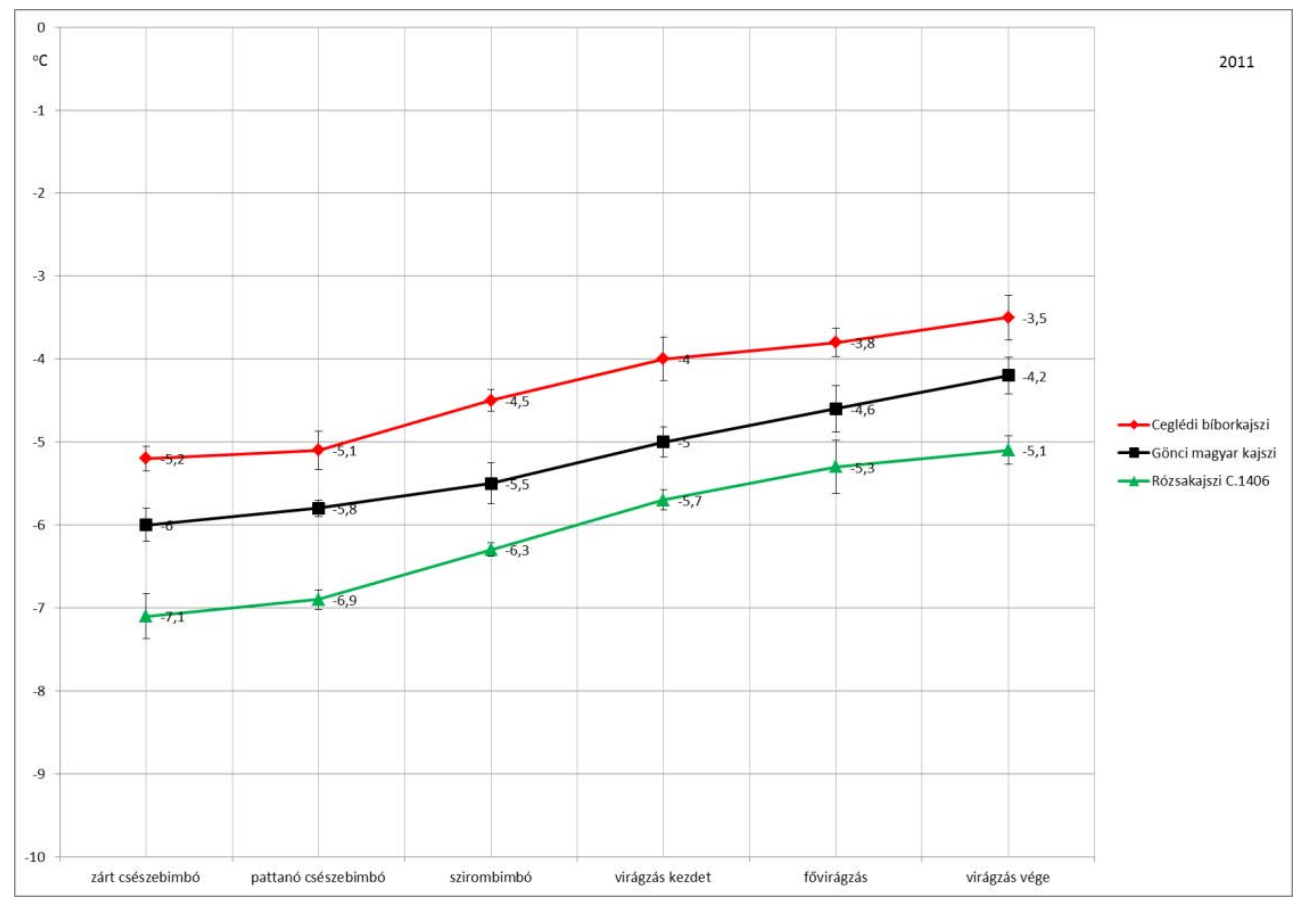

14. ábra: A három standard fajta átlagos fagytürési középértékei $\left(\mathrm{LT}_{50}\right)$ a virágzás különböző fenofázisaiban 2011-ben

A 15. ábrán a három standard fajta fagytürési középértékeit mutatjuk be a virágzás különböző fenofázisában 2012-ben. A lineáris regresszióval becsült LT Lo $_{50}$ érékeket a M.2.11. táblázatban közöljük. A korábbi évhez hasonlóan ebben a virágzási időszakban is csökkenést tapasztaltunk a virágzás előrehaladtával a fajták fagytürése tekintetében. A fagyérzékeny fajtának míg zárt csészebimbós állapotban $-5,2{ }^{\circ} \mathrm{C}$ volt az $\mathrm{LT}_{50}$ értéke, addig a virágzás kezdetén $-3,5{ }^{\circ} \mathrm{C}$, a virágzás végén pedig $-2{ }^{\circ} \mathrm{C}$. A fagytürő fajtának az $\mathrm{LT}_{50}$ értéke zárt csészebimbós állapotban $-6,5^{\circ} \mathrm{C}$, a virágzás végén ez az érték $-3,4^{\circ} \mathrm{C}$-ra csökkent. A virágzás végén a fagytürő fajták virágai $-1,4{ }^{\circ} \mathrm{C}$-al alacsonyabb hőmérsékletet is elviseltek, mint a fagyérzékeny fajtáké. 


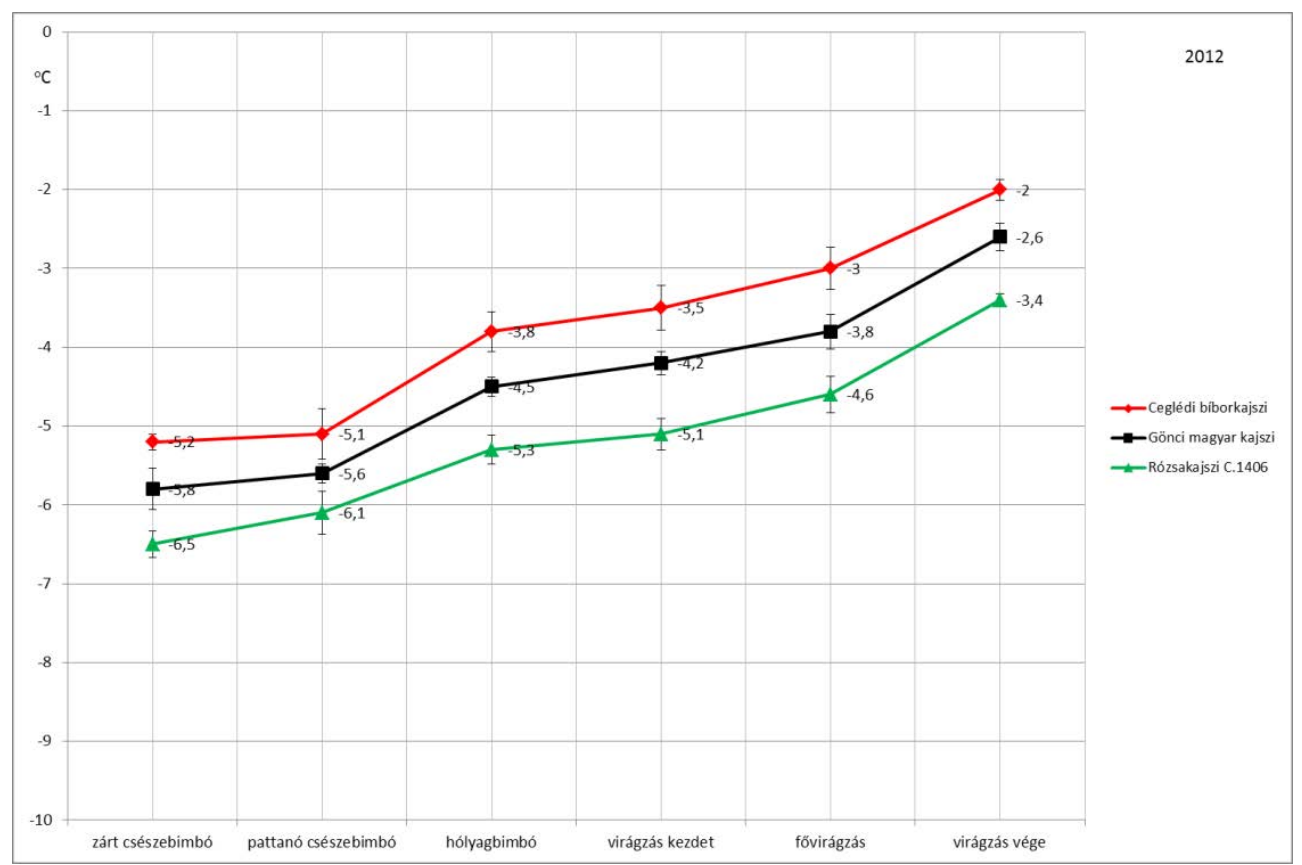

15. ábra: A három standard fajta átlagos fagytürési középértékei $\left(\mathrm{LT}_{50}\right)$ a virágzás különböző fenofázisaiban 2012-ben

A három standard fajta 2013-as virágzási eredményeit a 16. ábrán közöljük. A lineáris regresszióval becsült $\mathrm{LT}_{50}$ értékeket a M.2.12. táblázatban közöljük. A korábbi két évhez hasonló tendenciát mutat a 2013-as virágzási időszak is. A virágzás végén a fagyérzékeny és a fagytürő genotípus között $2,4{ }^{\circ} \mathrm{C}$ különbség volt.

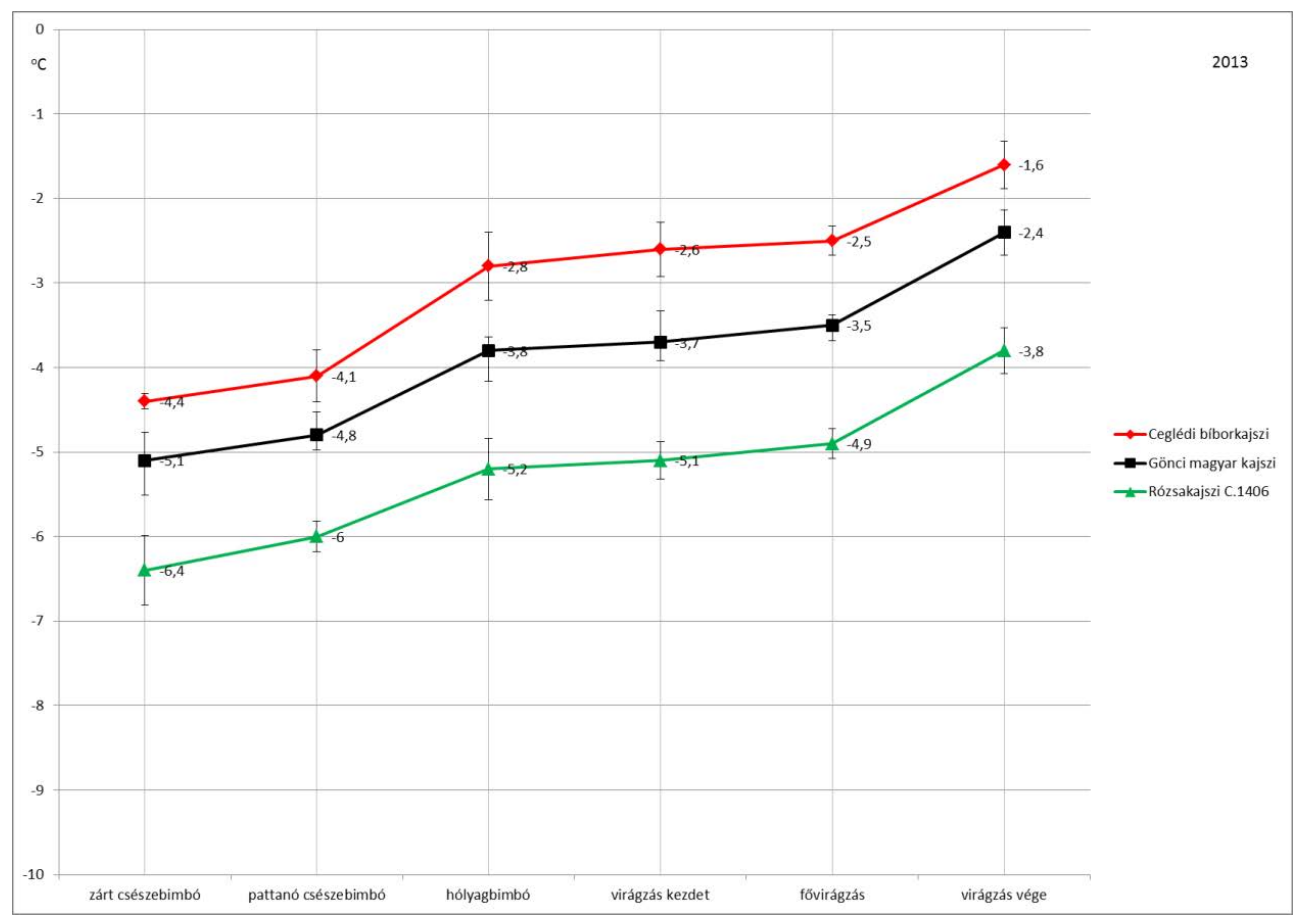

16. ábra: A három standard fajta átlagos fagytürési középértékei $\left(\mathrm{LT}_{50}\right)$ a virágzás különböző fenofázisaiban 2013-ban 
A kéttényezős blokkos elrendezésü ANOVA (3. modell) alapján állíthatjuk, hogy ebben a három évben szignifikáns évjárathatást és fajtahatást tudtunk kimutatni $\left(\mathrm{F}_{\text {év }}(2 ; 39)=81,97\right.$; $\left.\mathrm{p}<0,001 ; \mathrm{F}_{\text {fajta }}(2 ; 39)=241,92 ; \mathrm{p}<0,001\right)$. Emellett az interakció is szignifikánsnak bizonyult $(\mathrm{F}(4 ; 39)=4,9 ; \mathrm{p}<0,01)$. A szignifikáns interakció miatt a fajtahatást évenként, az évjárathatást pedig fajtánként elemeztük. A Tukey-féle post hoc teszt alapján mindhárom évben mindhárom fajta fagytürésének mértéke szignifikánsan különbözött a többiétöl $(\mathrm{p}<0,05)$. Ezen kívül a 'Ceglédi bíborkajszi' és 'Gönci magyar kajszi' esetében mindhárom év eredménye szignifikánsan különbözött a többiétől, míg a 'Rózsakajszi C.1406' fajtánál a 2012 és 2013-as évek eredményei nem különböztek szignifikánsan, ami arra utal, hogy a fagytüröképesség kissé lelassult tempóban csökkent.

\subsection{A három évjárat fagytürési eredményeinek összehasonlítása}

A három évjárat között kisebb különbségeket tapasztaltunk. A 17. ábrán a vizsgált három évjárat napi középértékeit tüntettük fel szeptember 1-től április 30-ig, valamint a napi hőmérsékletek 19 éves átlagát is ábrázoltuk. 2010/2011 és 2011/2012 telén az átlagosnál alacsonyabb hőmérsékleteket mértek, mind a két tél a több éves átlagnál hidegebb volt, kifejezetten hideg periódusokkal. 2012/2013 téli időjárása a több évi átlaghoz közel alakult, annál kissé hidegebb volt, viszont március közepétől ebben az évben mérték a legalacsonyabb hőmérsékleteket. A virágrügyek fagyállósága az edződési folyamat során fokozatosan alakult ki (7, 10, 13. ábrák). Az edződés mértékét a külső hőmérséklet változása befolyásolta. A tél második felében fokozatosan vesztették el a virágrügyek fagytürőképességüket, a csökkenés üteme nagymértékben függött a hőmérséklet változásától.

A kéttényezős blokkos elrendezésű ANOVA (2. modell) alapján állíthatjuk, hogy ebben a három évben szignifikáns évjárathatás nem volt kimutatható $\left(\mathrm{F}_{\text {év }}(2 ; 90)=0,41 ; \mathrm{p}=0,66\right)$. A fajtahatás azonban erösen szignifikáns volt $\left(\mathrm{F}_{\text {fajta }}(2 ; 90)=27,89 ; \mathrm{p}<0,001\right)$, míg szignifikáns interakciót nem találtunk $\left(\mathrm{F}_{\text {interakció }}(4 ; 90)=0,15 ; \mathrm{p}=0,96\right)$. A Tukey-féle post hoc teszt alapján mindhárom fajta fagytürésének mértéke szignifikánsan különbözött a többiétől $(p<0,05)$.

A 'Ceglédi bíborkajszi' fajta virágrügyeinek a tél során mért legjobb fagytürési középértéke kis különbséget mutatott a három évjáratban. A 2010/11-es télen $-20,8{ }^{\circ} \mathrm{C}$, a 2011/12-es télen $-20,5{ }^{\circ} \mathrm{C}$, míg a 2012/2013-as évben $-20,2{ }^{\circ} \mathrm{C}$ volt ez az érték. A 2013 -as évjáratban tehát $0,6{ }^{\circ} \mathrm{C}$-kal kevésbé volt ellenálló, mint a 2011-es évjáratban. A 'Rózsakajszi C.1406' fajta $\mathrm{LT}_{50}$ értékei a három évjáratban szintén csak kis mértékben különböztek egymástól. A fagyérzékeny fajtához hasonlóan 2010/2011 telén volt a legnagyobb ez az érték (- 
23,3 ${ }^{\circ} \mathrm{C}$ ). A 2013 -as évjáratban $0,4{ }^{\circ} \mathrm{C}$-kal kevésbé volt ellenálló, mint a 2011-es évjáratban. A tél második felében a virágrügyek fagyállósága fokozatosan csökkent. Míg 2010/2011 telén, január elején $2,5^{\circ} \mathrm{C}$ különbség volt a fagyérzékeny és a fagytürő genotípus virágrügyeinek fagytürési középértékei között, addig március vége felé már csak $1,5{ }^{\circ} \mathrm{C}$ volt ez az érték. 2011/2012 telén a leghidegebb hónapban $2,5{ }^{\circ} \mathrm{C}$ különbség volt a fagyérzékeny és fagytürő genotípus között, s az edződési időszak végére ez a különbség 2,4 ${ }^{\circ} \mathrm{C}$-ra csökkent. 2012/13 telén fordítva alakult ez a különbség, a leghidegebb hónapban kisebb volt a különbség a két fajta között, mint a virágzás elején.

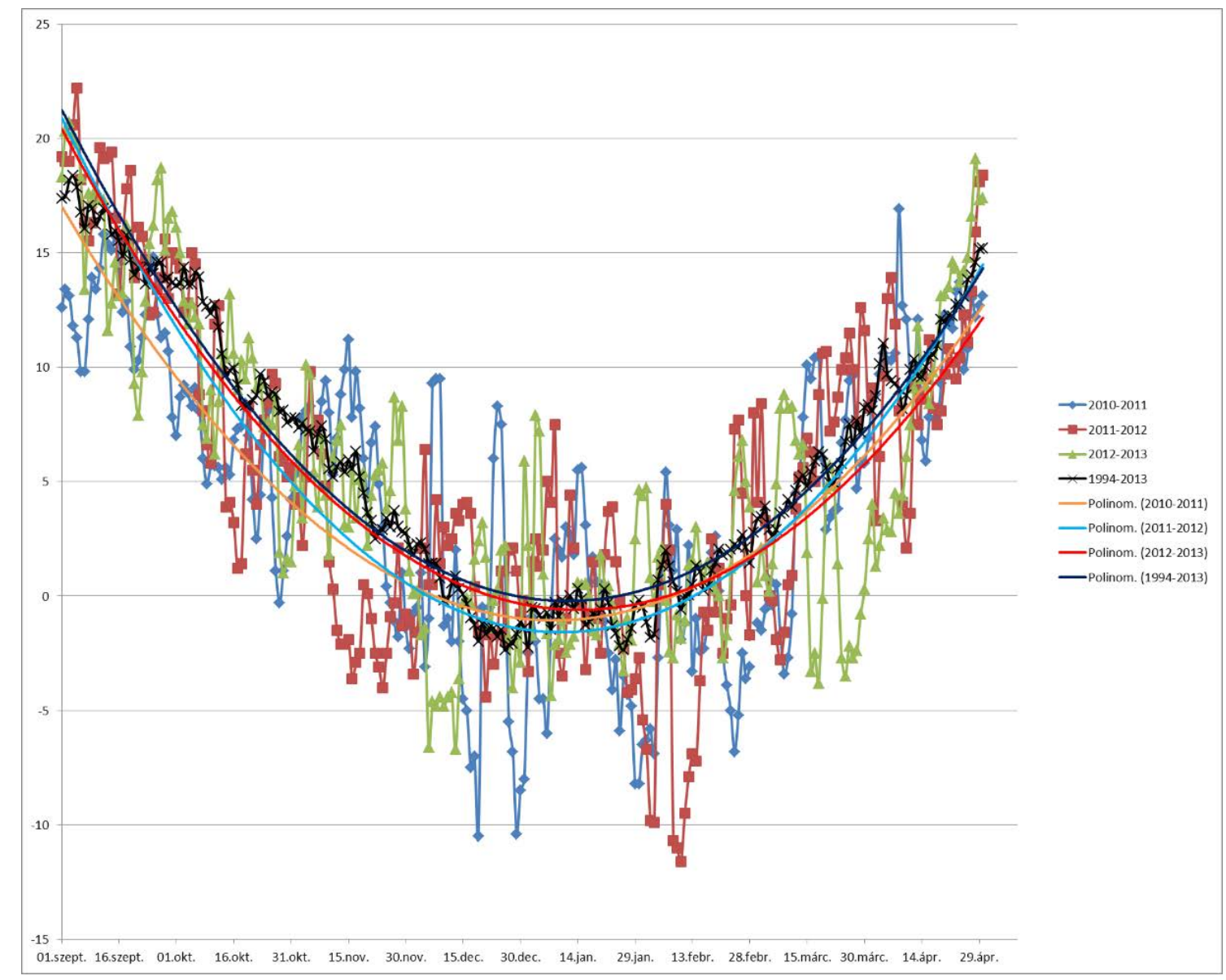

17. ábra: Napi középhőmérsékleti adatok a vizsgált évjáratokban Soroksáron, valamint a napi középhőmérsékletek 19 éves átlagai Soroksáron

A hároméves vizsgálati eredményeink alapján hierarchikus klaszteranalízissel csoportosítottuk a kajszifajtákat fagytürésük alapján (13. táblázat). A statisztikai vizsgálat során kapott dendrogrammokat az M.3.1-M.3.3. ábrákon szemléltetjük. Vizsgálati eredményeink alapján a legtöbb külföldi kajszifajta ('Aurora', 'Laycot', 'Sweet Red', 'Pinkcot', 'Sylvercot', 'Pisana', 'Sylred') érzékenyebbnek bizonyult a fagyérzékeny standard 'Ceglédi bíborkajszi' fajtához képest. Legfagyérzékenyebbnek az ‘Aurora', legfagytürőbbnek a 'Harlayne’ bizonyult. 
13. táblázat: Kajszifajták csoportosítása fagytürésük alapján ( mind a három csoportban a fajták sorrendje reprezentálja a fagyérzékenységük sorrendjét).

\begin{tabular}{|c|c|c|}
\hline Fagyérzékeny & Közepesen fagytürö & Fagytürő \\
\hline Aurora & Goldrich & Rózsakajszi C.1406 \\
\hline Laycot & Orange Red & Harlayne \\
\hline Sweet Red & Veecot & \\
\hline Pinkcot & Gönci magyar kajszi & \\
\hline Sylvercot & Bergarouge & \\
\hline Pisana & & \\
\hline Sylred & & \\
\hline Ceglédi bíborkajszi & & \\
\hline
\end{tabular}

\subsection{Kajszifajták mikrosporogenézise}

Kísérleti munkánk során három vizsgálati évben (2011, 2012, 2013), 8 külföldi kajszifajta ('Pinkcot', 'Orange Red', 'Harcot', 'Litoral', 'Harogem', 'Comandor', 'Sirena', 'Harlayne') mikrosporogenézisének folyamatát határoztuk meg (4. modell). Kontrollként a 'Gönci magyar kajszi’ fajtát választottuk. A vizsgált fajták között szignifikáns különbségeket találtunk a mikrosporogenézis ütemében, lefolyásában és az évjáratok között is. A 14. táblázatban a fenológiai stádiumok kezdetének időpontjait tüntettük föl. A füzér állapottól a pollen állapotig a stádiumok átmenetét jellemző szigmoid görbék 50\%-os értékéhez tartozó kvantilisét vettük figyelembe, a virágzáskezdetnél pedig az 5\%-os értékhez tartozó kvantilist. A táblázatban az időpontok Julián napban vannak kifejezve, tehát a január 1-től eltelt napok számát jelentik.

A vizsgálati éveknek az egyes fenológiai fázisok kezdőpontja szerinti összehasonlítására ismételt méréses ANOVA modellt használtunk. A pollen anyasejt stádium kivételével a MANOVA-teszt szignifikáns eltérést mutatott (Wilk $\lambda<0,3, \mathrm{p}<0,01$; pollen anyasejt stádium: Wilk $\lambda>0,95, p=0,83)$. A szfericitás sérülése miatt Greeshouse-Geisser korrekciót végeztünk $(\varepsilon>0,83)$. Minden fenofázisra szignifikáns évjárathatást tudtunk kimutatni $\left(\mathrm{F}\left(2^{*} \varepsilon ; 16^{*} \varepsilon\right)>20\right.$, $\mathrm{p}<0,01)$ a pollen anyasejt stádium kivételével $(\mathrm{F}(1,1 ; 8,7)=0,17, \mathrm{p}=0,71)$. A Bonferroni-féle páronkénti összehasonlítás alapján a virágzás és a pollenszemek kialakulása stádiumok esetében minden év szignifikánsan különbözött egymástól $(\mathrm{p}<0,01)$, a füzér, a tetrád és a mikrospóra stádiumok esetében a 2012-es év szignifikánsan különbözött $(\mathrm{p}<0,01)$ az egymáshoz hasonló 2011-es és 2013-as évektől ( $p>0,05)$, míg a pollen anyasejt stádium esetében $(p>0,99)$ mind a három vizsgálati év egymáshoz hasonlóan alakult. 
14. táblázat: A mikrosporogenézis stádiumainak kezdeti időpontjai kajszifajtákban, 3 egymást követő évben (a január 1-től eltelt napok száma)

\begin{tabular}{|c|c|c|c|c|c|c|c|c|c|c|c|c|}
\hline \multirow{2}{*}{$\frac{\text { Fajta/év }}{2011}$} & \multicolumn{2}{|c|}{ füzér } & \multicolumn{2}{|c|}{ pollen anyasejt } & \multicolumn{2}{|c|}{ tetrád } & \multicolumn{2}{|c|}{ mikrospóra } & \multicolumn{2}{|c|}{ pollen } & \multicolumn{2}{|c|}{ virágzás } \\
\hline & $m$ & $s$ & $m$ & $s$ & $m$ & $s$ & $m$ & $s$ & $m$ & $s$ & $m$ & $s$ \\
\hline Pinkcot & 25 & 0.25 & 34 & 0.37 & 38 & 0.45 & 47 & 0.66 & 76 & 0.54 & 84 & 1.30 \\
\hline Orange Red & 27 & 0.29 & 35 & 0.35 & 39 & 0.50 & 47 & 0.6 & 78 & 0.61 & 85 & 1.58 \\
\hline Harcot & 30 & 0.29 & 37 & 0.38 & 41 & 0.47 & 49 & 0.5 & 78 & 0.62 & 84 & 1.58 \\
\hline Gönci magyar kajszi & 32 & 0.28 & 40 & 0.37 & 43 & 0.45 & 52 & 0.56 & 79 & 0.57 & 86 & 1.55 \\
\hline Litoral & 34 & 0.29 & 40 & 0.35 & 45 & 0.48 & 53 & 0.47 & 80 & 0.53 & 87 & 1.45 \\
\hline Harogem & 36 & 0.30 & 43 & 0.38 & 48 & 0.50 & 56 & 0.51 & 81 & 0.52 & 91 & 1.45 \\
\hline Comandor & 36 & 0.30 & 43 & 0.38 & 48 & 0.50 & 56 & 0.51 & 81 & 0.52 & 91 & 1.45 \\
\hline Sirena & 38 & 0.30 & 44 & 0.32 & 49 & 0.46 & 57 & 0.50 & 82 & 0.64 & 92 & 1.45 \\
\hline Harlayne & 40 & 0.29 & 46 & 0.32 & 51 & 0.47 & 59 & 0.74 & 84 & 0.56 & 93 & 1.45 \\
\hline 2012 & $\mathrm{~m}$ & $\mathrm{~s}$ & $\mathrm{~m}$ & $\mathrm{~s}$ & $\mathrm{~m}$ & $\mathrm{~s}$ & $\mathrm{~m}$ & $\mathrm{~s}$ & $\mathrm{~m}$ & $\mathrm{~s}$ & $\mathrm{~m}$ & $\mathrm{~s}$ \\
\hline Pinkcot & 11 & 0.37 & 24 & 0.37 & 38 & 0.45 & 52 & 0.57 & 73 & 0.69 & 80 & 1.19 \\
\hline Orange Red & 15 & 0.31 & 27 & 0.36 & 39 & 0.46 & 53 & 0.51 & 74 & 0.52 & 82 & 1.09 \\
\hline Harcot & 18 & 0.35 & 32 & 0.39 & 46 & 0.45 & 58 & 0.33 & 76 & 0.75 & 83 & 0.92 \\
\hline Gönci magyar kajszi & 20 & 0.31 & 37 & 0.36 & 51 & 0.47 & 64 & 0.60 & 77 & 0.77 & 83 & 1.95 \\
\hline Litoral & 24 & 0.31 & 42 & 0.35 & 54 & 0.39 & 67 & 0.67 & 79 & 0.76 & 85 & 1.11 \\
\hline Harogem & 28 & 0.31 & 45 & 0.35 & 57 & 0.40 & 70 & 0.57 & 80 & 0.75 & 86 & 1.73 \\
\hline Comandor & 28 & 0.31 & 45 & 0.35 & 57 & 0.40 & 70 & 0.57 & 80 & 0.75 & 86 & 1.73 \\
\hline Sirena & 31 & 0.33 & 48 & 0.34 & 61 & 0.39 & 72 & 0.63 & 81 & 0.70 & 88 & 2.19 \\
\hline Harlayne & 36 & 0.33 & 54 & 0.39 & 66 & 0.54 & 75 & 0.57 & 83 & 0.89 & 89 & 2.19 \\
\hline 2013 & $\mathrm{~m}$ & $\mathrm{~s}$ & $\mathrm{~m}$ & $\mathrm{~s}$ & $\mathrm{~m}$ & $\mathrm{~s}$ & $\mathrm{~m}$ & $\mathrm{~s}$ & $\mathrm{~m}$ & $\mathrm{~s}$ & $\mathrm{~m}$ & $\mathrm{~s}$ \\
\hline Pinkcot & 25 & 0.25 & 32 & 0.35 & 37 & 0.45 & 49 & 0.57 & 79 & 0.55 & 100 & 0.98 \\
\hline Orange Red & 29 & 0.27 & 34 & 0.37 & 39 & 0.35 & 50 & 0.64 & 79 & 0.55 & 101 & 0.85 \\
\hline Harcot & 31 & 0.26 & 38 & 0.44 & 42 & 0.59 & 52 & 0.54 & 80 & 0.59 & 102 & 0.74 \\
\hline Gönci magyar kajszi & 33 & 0.24 & 39 & 0.34 & 43 & 0.61 & 53 & 0.54 & 81 & 0.57 & 103 & 0.88 \\
\hline Litoral & 35 & 0.29 & 39 & 0.34 & 45 & 0.41 & 55 & 0.68 & 82 & 0.56 & 103 & 0.76 \\
\hline Harogem & 36 & 0.28 & 42 & 0.37 & 46 & 0.41 & 55 & 0.45 & 82 & 0.56 & 104 & 0.77 \\
\hline Comandor & 36 & 0.28 & 42 & 0.37 & 46 & 0.41 & 55 & 0.45 & 82 & 0.56 & 104 & 0.77 \\
\hline Sirena & 38 & 0.30 & 44 & 0.38 & 48 & 0.45 & 58 & 0.54 & 83 & 0.59 & 104 & 0.64 \\
\hline Harlayne & 41 & 0.31 & 49 & 0.39 & 53 & 0.45 & 61 & 0.56 & 84 & 0.54 & 104 & 0.65 \\
\hline
\end{tabular}

m: a fenológiai stádiumok kezdeti időpontját kényszernyugalomtól a pollen stádiumig a szigmoid görbék inflexiós pontjában, azaz az 50\%-os kvantilinél határoztuk meg; a virágzás kezdetét az 5\%-os kvantilis mutatja

s: sebességi tényező (a szigmoid görbe meredeksége az 50\%-os kvantilisnél s/4) 
A fenológiai fázisok kezdőpontjára számított variációs koefficiensek $(\mathrm{CV})$ kéttényezős varianciaanalízisel való összehasonlítása során nem tudtunk szignifikáns fajtahatást kimutatni $(\mathrm{F}(8 ; 40)=0,53 ; \mathrm{p}=0,83)$, míg a fenológiai stádium hatása szignifikánsnak bizonyult $(\mathrm{F}(5 ; 40)=$ 13,93; $\mathrm{p}<0,001)$. A Games-Howell post hoc teszt eredményeit a 15. táblázat mutatja a fenológiai stádiumok variabilitását (CV-vel kifejezve) az alábbi sorrendben: füzér, pollen anyasejt, tetrád, mikrospóra, pollenszemek képződése. Ez a sorrend minden fajtára és minden évre azonos volt.

15. táblázat: Kajszifajták fenológiai stádiumainak kezdeti időpontjának variabilitását kifejező variációs koeffiensei a három vizsgálati évben. A különböző betük (A-C) a variációs koefficiens szignifikánsan különböző értékeit jelölik a Games-Howell-féle post hoc teszt szerint $(p<0,05)$.

\begin{tabular}{ccccccc}
\hline Fajta & füzér $^{\mathrm{A}}$ & pollen anyasejt $^{\mathrm{BC}}$ & tetrád $^{\mathrm{AB}}$ & mikrospóra $^{\mathrm{AB}}$ & pollen $^{\mathrm{C}}$ & virágzás $^{\mathrm{C}}$ \\
\hline Pinkcot & 0.40 & 0.18 & 0.02 & 0.05 & 0.04 & 0.03 \\
Orange Red & 0.31 & 0.13 & 0.10 & 0.10 & 0.03 & 0.03 \\
Harcot & 0.27 & 0.09 & 0.06 & 0.09 & 0.03 & 0.04 \\
Gönci magyar kajszi & 0.26 & 0.04 & 0.10 & 0.12 & 0.03 & 0.02 \\
Litoral & 0.20 & 0.04 & 0.11 & 0.13 & 0.02 & 0.07 \\
Harogem & 0.14 & 0.04 & 0.12 & 0.14 & 0.01 & 0.03 \\
Comandor & 0.14 & 0.04 & 0.12 & 0.14 & 0.01 & 0.03 \\
Sirena & 0.11 & 0.05 & 0.14 & 0.13 & 0.01 & 0.04 \\
Harlayne & 0.07 & 0.08 & 0.14 & 0.13 & 0.01 & 0.02 \\
\hline
\end{tabular}

A fajták és az évjáratok közötti különbségek elemzéséhez a mikrosporogenézis három stádiumát emeltük ki. A füzér állapotot, ami a virágrügyek mélynyugalmának végét jelzi, a mikrospóra állapotot, amikor lezajlott a redukciós osztódás, és elkezdődött a pollenszemek kialakulása, valamint a virágzási idő kezdetét, ami a mikrosporogenézis folyamatának végét jelzi. A vizsgált fajták közül mindhárom évben a 'Pinkcot' fajta virágrügyfejlődése volt a leggyorsabb, és a 'Harlayne' fajtáé a leglassabb. A kísérletbe vont többi fajta, és a kontrollként használt 'Gönci magyar kajszi' fajta mikrosporogenézisének üteme is e kettő fajtáé között volt. A 18. ábrán ennek a három fajtának a 2011 évi vizsgálati eredményeit mutatjuk be. Az ábrán a három kijelölt stádium (füzér, mikrospóra, virágzáskezdet) kialakulását tüntettük föl. A fenológiai stádiumok megjelenését tekintve a fajták sorrendje nagyon hasonló volt minden évben, minden fenológiai stádiumban (Friedman teszt: $\left.\chi^{2 \cdot}(2)<0,4 ; p>0,8\right)$. Az egyre későbbi fenológiai stádiumban azonban a fenológiai fázisok kezdőpontjainak szórása többnyire kisebb volt. Az ezt igazoló negatív lineáris trend szignifikáns volt (Pearson-féle $\mathrm{R}=-0,47 ; \mathrm{p}<0,01$ ). A 
füzér és a virágzás fázisok esetében azt is bizonyítottuk, hogy minél később kezdődik a stádium az egyik évben, akkor az annál gyorsabban fog lezajlani.

A mikrosporogenézis kezdetén hosszabb időt vett igénybe a fenológiai stádiumok kialakulása, mint később. Az archespórium szövetből a füzér állapot kialakulása 20-24 napot vett igénybe minden vizsgált fajtánál. A tetrád állapotból a mikrospóra állapotba való átmenet 10-14 nap alatt zajlott le. A virágzás pedig 3-5 nap alatt játszódott le (18. ábra).

Kéttényezős ANOVA-tesztet használva igazoltuk, hogy a sebességi tényezők fenológiai stádiumonként erősen szignifikáns különbséget mutattak $(F(5 ; 106)=262,94 ; p<0,001)$, míg a fajták esetében a különbség nem volt szignifikáns $(\mathrm{F}(8 ; 106)=0,43 ; \mathrm{p}=0,90)$. Az interakció sem volt szignifikáns $(\mathrm{F}(40 ; 106)=0,71 ; \mathrm{p}=0,89)$. A Tukey-féle post hoc teszt alapján elmondható, hogy a fenológiai stádiumok sebességi tényezői szignifikánsan különböznek az összes többitől a mikrospóra és a pollenszem kivételével $(p<0,001 ; p=0,15)$.

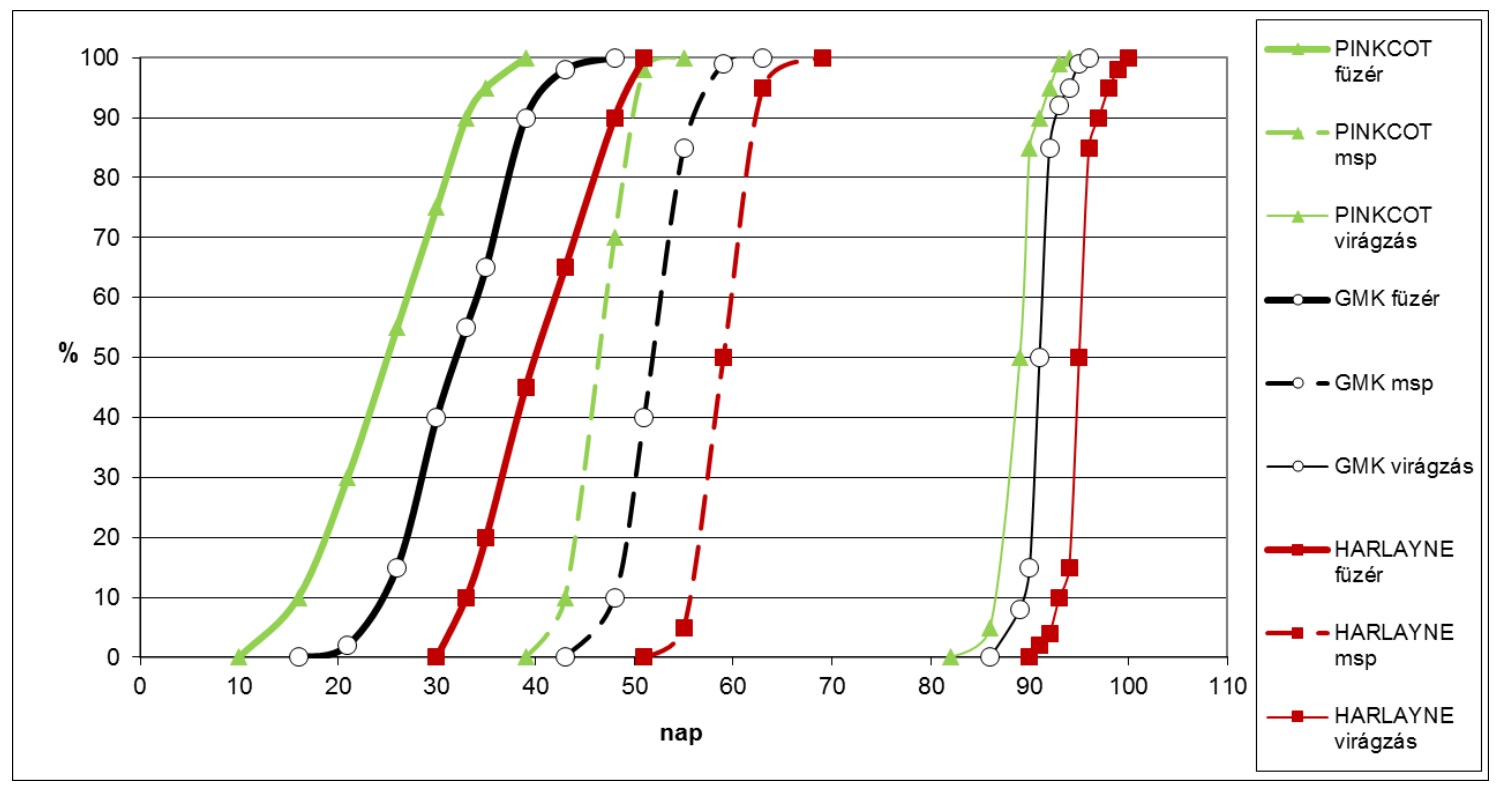

18. ábra: Három kajszifajta mikrosporogenézisének kezdete és vége, valamint a mikrospóra állapot kialakulása 2011-ben

Az évjáratok közötti különbségek elemzéséhez a közepes virágrügy fejlődési ütemü 'Litoral' fajta 3 éves vizsgálati eredményeit mutatjuk be (19. ábra). A virágrügyek mélynyugalmának vége (füzér állapot) 2011-ben és 2013-ban egy időpontban volt, az átmenet napja február 3-ára esett ezekben az években a 'Litoral' fajtánál. 2012-ben 10 nappal korábban következett be a mélynyugalom vége, mint a másik két évjáratban. A mikrosporogenézis stádiumainak kialakulása különböző időtartamokat vett igénybe az egyes években. Ez az évjáratok eltérő időjárásának köszönhető. 2011-ben a mélynyugalom vége után hamar lezajlott a mikrospórák kialakulása a 'Litoral' fajta virágrügyeiben. Február 22.-én volt a mikrospóra 
állapot kezdete. A virágzás viszont nem ebben az évben volt a legkorábbi. Március 30-án kezdődött a virágzás, ami a másik két évjárat közötti időpontot jelent. 2012-ben a korai füzér állapot után a mikrospórák kialakulása az évjáratok közül a legkésőbb következett be, majd a folyamat végén, a három év legkorábbi virágzás-kezdetét figyeltük meg. A 'Litoral' március 25én kezdett virágozni ebben az évben. 2013-ban a mikrosporogenézis folyamata a 2011 évihez nagyon hasonlóan kezdődött. A füzér állapot azzal megegyező időpontban következett be, a mikrospórák kialakulása pedig 2 nappal később. A virágzás viszont ebben az évben volt a legkésőbbi. A 'Litoral' fajta virágzásának kezdetét április 14-én figyeltük meg.

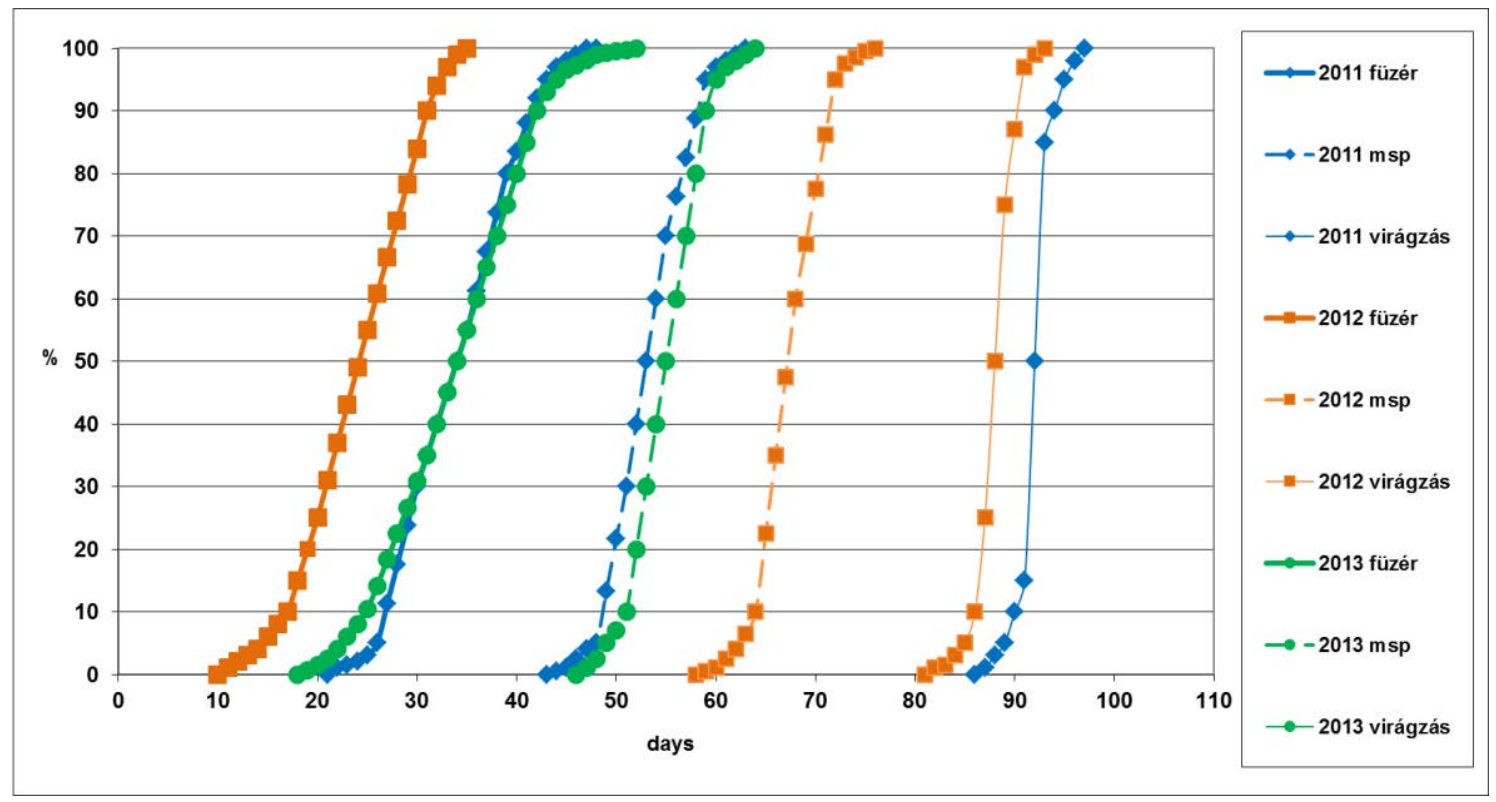

19. ábra: A mikrosporogenézis jellemző fenológiai stádiumainak kialakulása a 'Litoral' fajtában, három egymást követő évjáratban (2011-2013)

\subsection{Az áruértéket meghatározó fizikai tulajdonságok}

\subsubsection{Tömeg-és méretparaméterek}

A kajszi ipari és házi feldolgozása mellett növekedő tendenciát mutat a friss piaci értékesítése is. A friss piaci értékesítésnél a gyümölcsök mérete az egyik meghatározó minőségi paraméter. A gyümölcs méretét több tényező (fajta genetikai háttere, fa életkora, a virágok berakódottsága, a termesztési és környezeti tényezök) együttesen határozza meg. Kutatómunkánk során két évben (2011, 2013), s három különböző érettségi állapotban (70\%, 80\% és 90\%) határoztuk meg a vizsgálatba vont kajszifajták gyümölcstömegét (20. és 21. ábra) és méretparamétereit (22. és 23. ábra illetve M.3.4.-M.3.7.). Eredményeink alapján elmondható, hogy az érés előrehaladtával növekvő tendenciát tudtunk kimutatni a gyümölcs tömege és méret paraméterei tekintetében. 
A kéttényezős MANOVA (Wilk-féle lambda) alapján állíthatjuk (5. modell), hogy a vizsgált két évben, mind a három érettségi állapotban szignifikáns fajtahatást és évjárathatást tudtunk kimutatni. Ebben kivételt képezett a 70\%-os érettség, melyben a gyümölcsök magasságában nem találtunk szignifikáns különbséget az évek között (M.2.13. táblázat). Elmondható továbbá, hogy minden egyes tömeg- és méretparaméterre szignifikánsan hat a fajta és az év is. Minden érettségi állapotban szignifikánsnak bizonyult az interakció is, ezért a fajtahatást évenként, az évjárathatást pedig fajtánként elemeztük. A Pearson-féle korrelációs együttható alapján $(\mathrm{p}<0,001)$ minden fizikai paraméter szignifikánsan korrelál egymással. A Tukey/Games Howell-féle post hoc teszt alapján mindkét évben a fajták tömeg- és méretparamétereinek alakulása tekintetében szignifikáns különbségeket tudtunk kimutatni. A 20. ábrán 13 kajszifajta gyümölcstömegét ábrázoltuk három érettségi állapotban a 2011-es évben. 70\%-os érettségben 33,5-88,09 g, 80\%-os érettségben 39-98 g, 90\%-os érettségben pedig 48,6111,5 g között alakult átlagosan a fajták gyümölcstömege. A 2013-as évben a fajtáknál a korábbi évhez képest kisebb gyümölcstömeget mértünk. 70\%-os érettségben 40,6-76,2 g, 80\%-os érettségben 45,3-83,1 g, míg 90\%-os érettségben 49,3-92,8 g volt a fajtáknál az átlagos gyümölcstömeg (21. ábra). Mind a két évben, mindegyik érettségi stádiumban az 'Aurora' gyümölcsei voltak a legkisebb tömegüek, míg majdnem mindegyik érettségi stádiumban a 'Sylvercot' fajta gyümölcsei voltak a legnagyobbak. A 'Gönci magyar kajszi' kontrollhoz képest kisebb gyümölcstömeget mértünk a 'Harogem' 'Litoral' és az 'Orange Red' esetében, míg a 'Bergarouge' 'Goldrich' és 'Pinkcot' fajták nagyobbak voltak. 


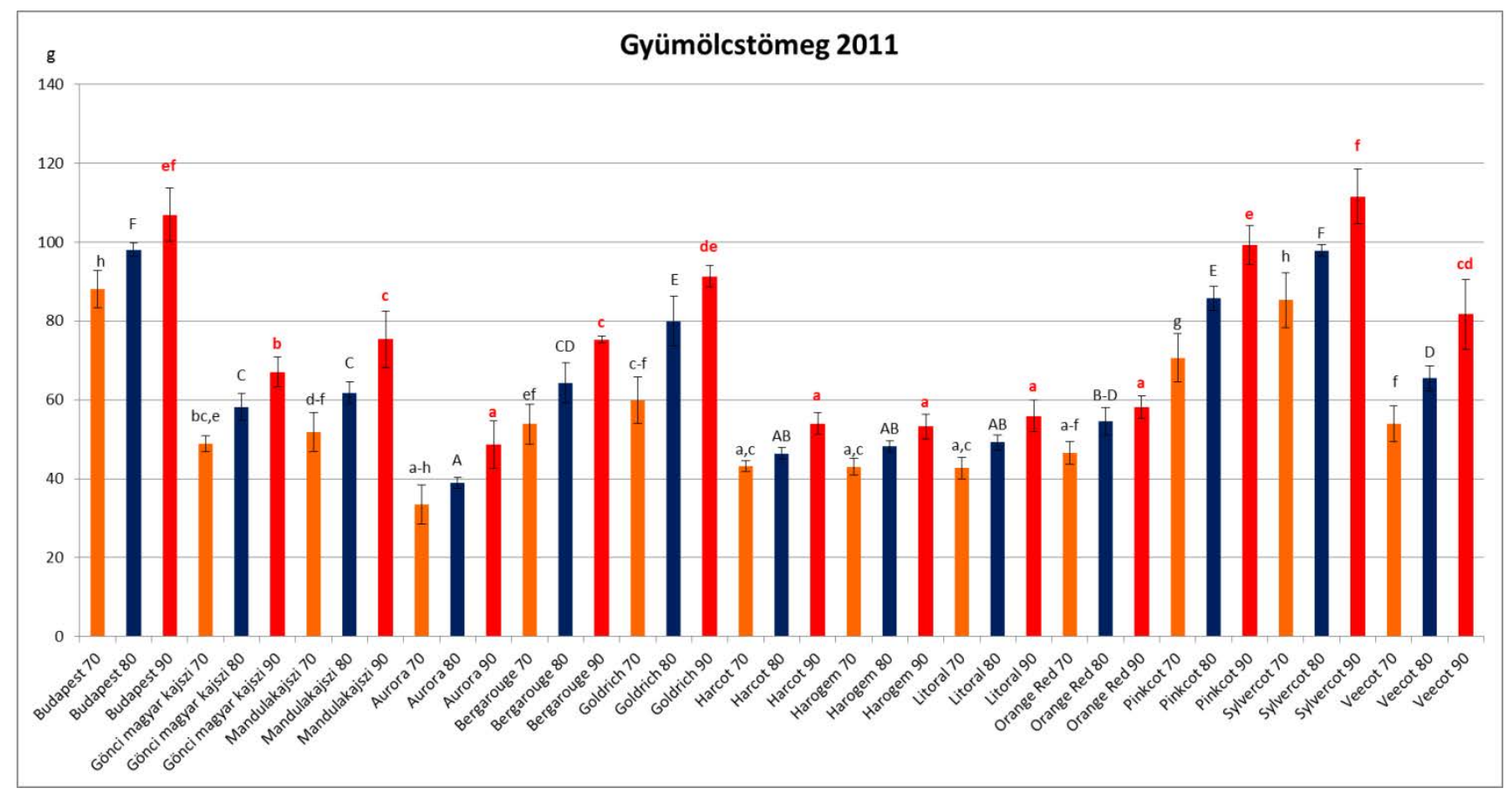

20. ábra: A vizsgált kajszifajták gyümölcstömege 2011-ben. Az oszlopok magassága a mérések átlagát, a vonalak a szórást mutatják (n=10). A különböző betük szignifikánsan különböző csoportokat jelölnek a Games-Howell- /Tukey-féle post hoc teszt szerint $\mathrm{p}<0,05$ szinten (kisbetü: 70\%-os érettség; nagybetü: 80\%-os érettség; piros kisbetü 90\%-os érettség).

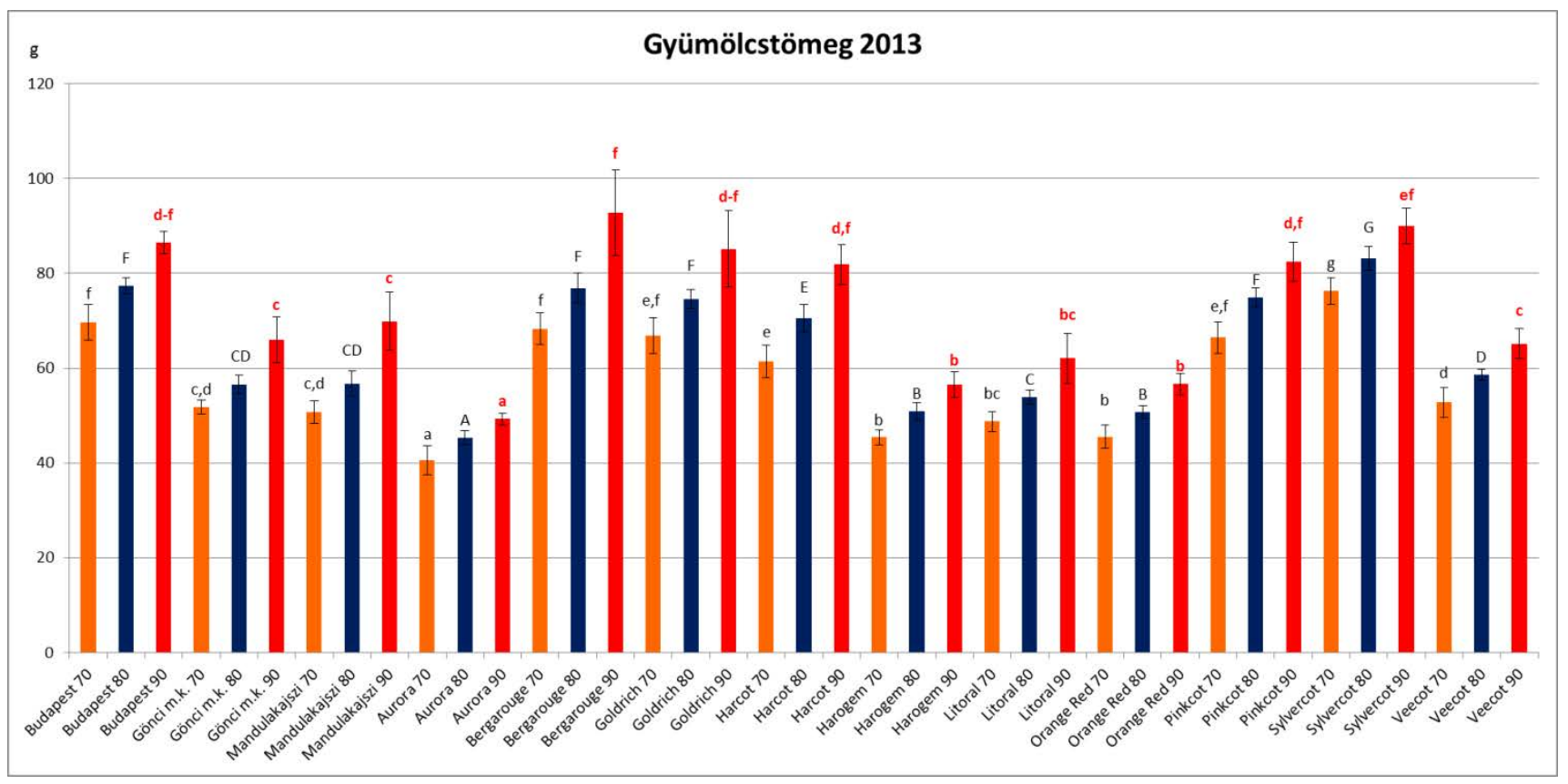

21. ábra: A vizsgált kajszifajták gyümölcstömege 2013-ban. Az oszlopok magassága a mérések átlagát, a vonalak a szórást mutatják $(\mathrm{n}=10)$. A különböző betük szignifikánsan különböző csoportokat jelölnek a Games-Howell- /Tukey-féle post hoc teszt szerint $\mathrm{p}<0,05$ szinten (kisbetü: 70\%-os érettség; nagybetü: 80\%-os érettség; piros kisbetü 90\%-os érettség).

A 22. ábrán a kajszifajtákat a gyümölcsök szélessége alapján különítettük el 2011-ben, három különböző érettségi állapotban. 70\%-os érettségben 38-52,4 mm, 80\%-os érettségben 
38,5-55,2 mm, 90\%-os érettségben pedig 42,3-56,8 mm között alakult átlagosan a fajták gyümölcsének szélessége. A 2013-as évben, 70\%-os érettségben 40,4-52,4 mm, 80\%-os érettségben 42,4-53,7 mm, míg 90\%-os érettségben 43,6-57,4 mm volt a fajtáknál az átlagos gyümölcsszélesség (23. ábra). Mind a két évben, mindegyik érettségi stádiumban az 'Aurora' gyümölcsének szélessége volt a legkisebb, míg a 'Budapest', 'Bergarouge', és 'Sylvercot' fajtáknak volt a legnagyobb.

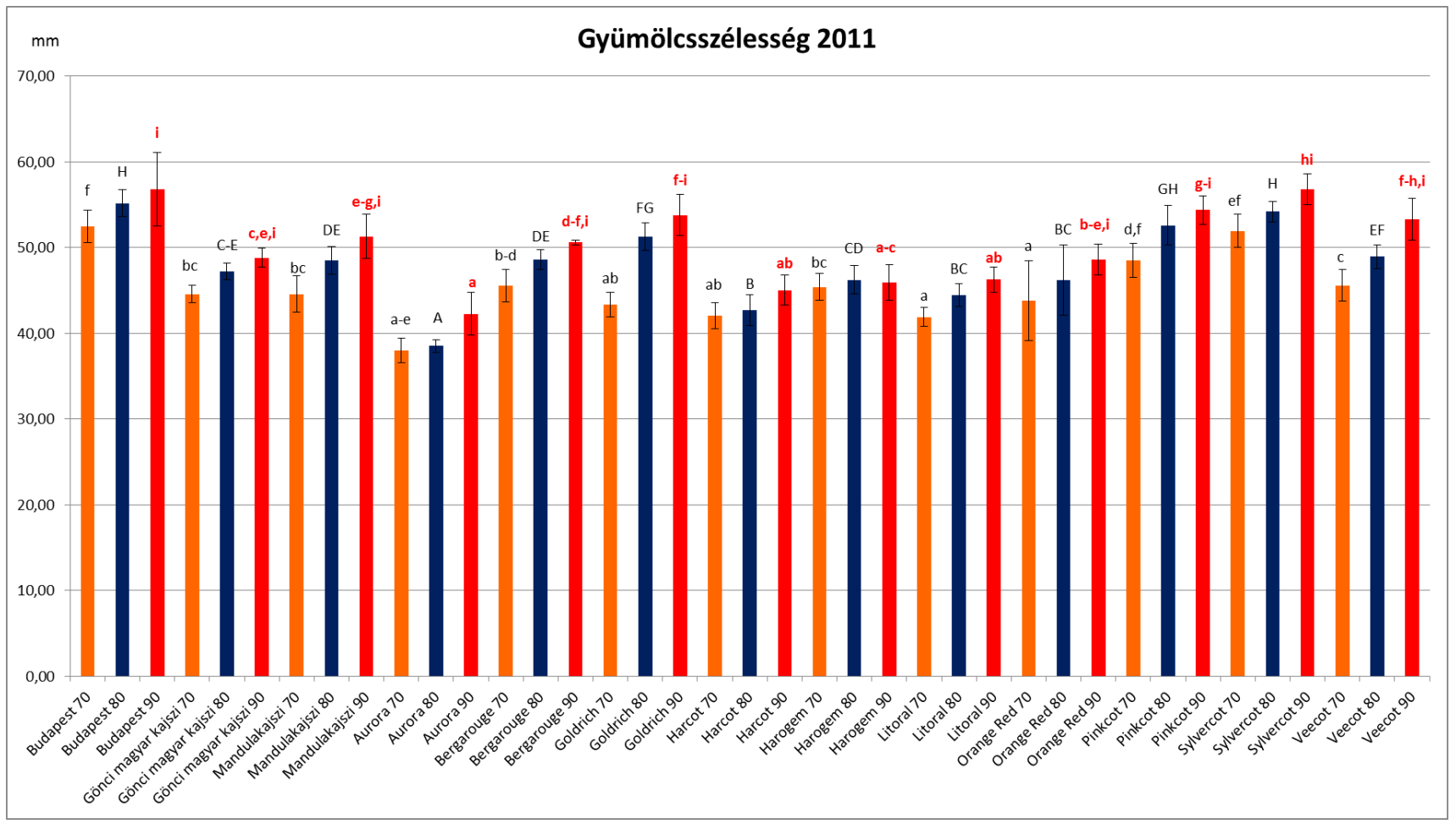

22. ábra: A vizsgált kajszifajták gyümölcseinek szélessége 2011. Az oszlopok magassága a mérések átlagát, a vonalak a szórást mutatják $(\mathrm{n}=10)$. A különböző betük szignifikánsan különböző csoportokat jelölnek a Games-Howell- /Tukey-féle post hoc teszt szerint $p<0,05$ szinten (kisbetű: 70\%-os érettség; nagybetü: 80\%-os érettség; piros kisbetü 90\%-os érettség). 


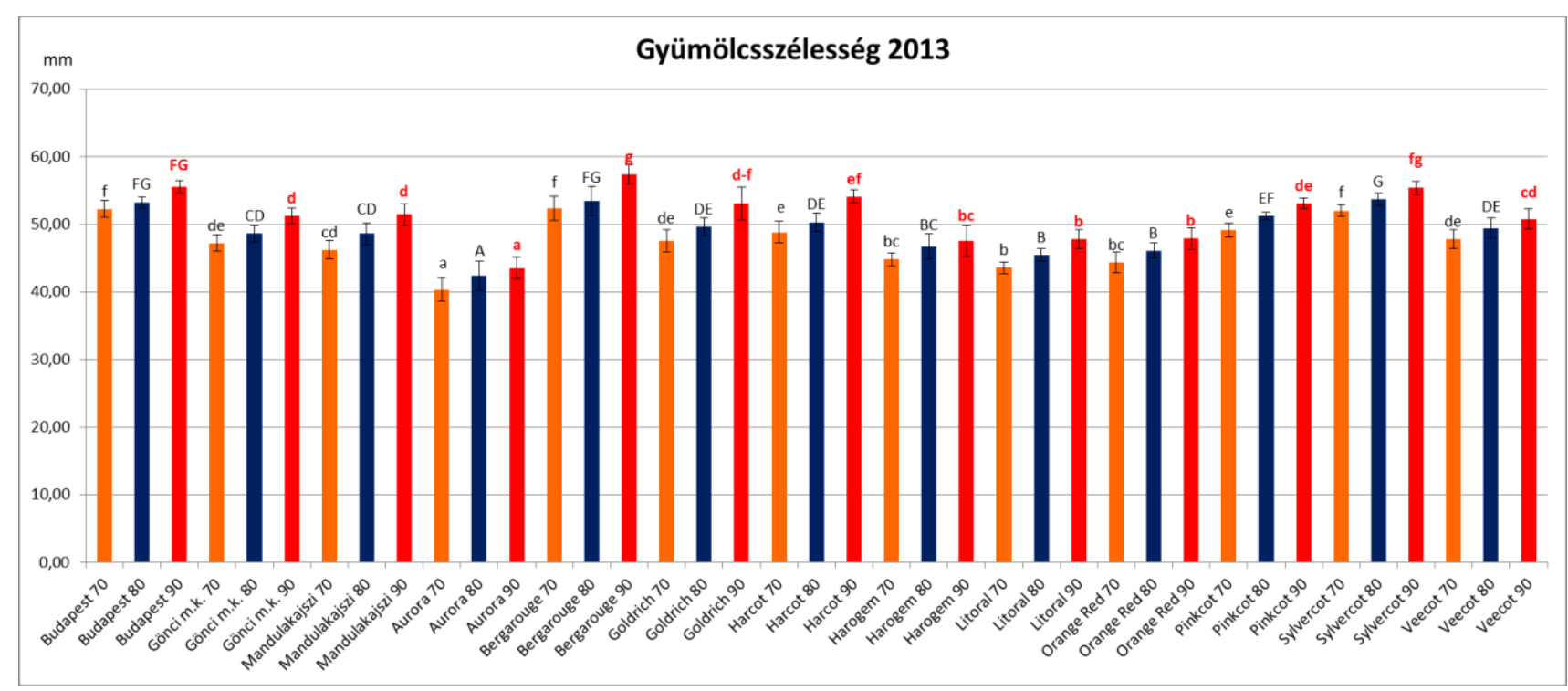

23. ábra: A vizsgált kajszifajták gyümölcseinek szélessége 2013. Az oszlopok magassága a mérések átlagát, a vonalak a szórást mutatják $(\mathrm{n}=10)$. A különböző betük szignifikánsan különböző csoportokat jelölnek a Games-Howell- /Tukey-féle post hoc teszt szerint $p<0,05$ szinten (kisbetü: 70\%-os érettség; nagybetü: 80\%-os érettség; piros kisbetü 90\%-os érettség).

\subsubsection{Gyümölcshúsállomány vizsgálat}

\subsubsection{Kajszifajták húskeménységének alakulása a kézi penetrométeres eredmények alapján}

A fajták gyümölcsminőségi paraméterei közül piaci szempontból kiemelt jelentőségü a húskeménység. Vizsgálataink során 2 évben $(2011,2013)$ és három érettségi stádiumban (70\%, $80 \%$ és 90\%) vizsgáltuk a különböző kajszifajták húskeménységének alakulát (24. és 25. ábra). A mérési eredmények alapján elmondható, hogy az érés előrehaladtával csökkent a kajszifajták húskeménysége, illetve a gyümölcs napos oldalán puhábbak voltak a gyümölcsök, mint az árnyékos oldalon.

Annak meghatározására, hogy a húskeménységet szignifikáns módon befolyásolja a genotípus, illetve az évjárat hatása, kéttényezős MANOVA elemzést végeztünk (6. modell, M.2.14. táblázat). A Wilk-féle lambda alapján elmondható, hogy a húskeménységre szignifikánsan hat a fajta, valamint az év is. A vizsgált két évben szignifikáns évjárathatást és fajtahatást tudtunk kimutatni mind a három érettségi állapotban a gyümölcs napos és árnyékos oldalán egyaránt, emellett az interakció is szignifikánsnak bizonyult. A szignifikáns interakció miatt a fajtahatást évenként, az évjárathatást pedig fajtánként elemeztük. A Tukey/Games Howell-féle post hoc teszt alapján mindkét évben a fajták húskeménységének alakulása tekintetében szignifikáns különbségeket tudtunk kimutatni. 
A 24. ábrán a vizsgált kajszifajták húskeménységének átlagértékeit ábrázoltuk 2011-ben, három érettségi stádiumba, a gyümölcs napos és árnyékos oldalán. 2011-ben a gyümölcsök húskeménysége 70\%-os érettségben, a napos oldalon: $1,3-11 \mathrm{~kg} / \mathrm{cm}^{2}$, az árnyékos oldalon: 1,5-

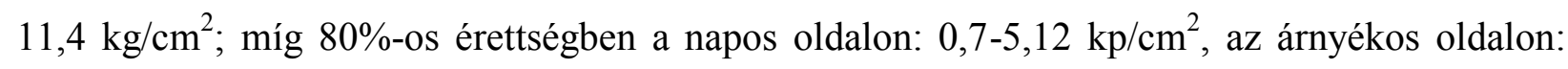
0,9-6,42 kg/ $\mathrm{cm}^{2}$ volt. $90 \%$-os érettségben pedig a gyümölcs napos oldalán: $0,1-2,92 \mathrm{~kg} / \mathrm{cm}^{2}$, az árnyékos oldalán: 0,2-3,36 kg/ $\mathrm{cm}^{2}$ között alakult a kajszifajták húskeménysége. Míg 2013-ban ezek az értékek 70\%-os érettségben a gyümölcs napos oldalán: 1,6-5,8 kg/ $\mathrm{cm}^{2}$, az árnyékos

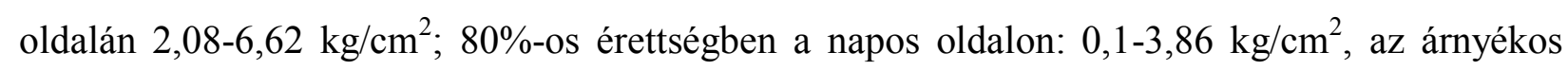
oldalon: 0,28-4,6 kg/ $\mathrm{cm}^{2}$ voltak. 90\%-os érettségben pedig a húskeménységi értékek a gyümölcs napos oldalán: $0,1-2,58 \mathrm{~kg} / \mathrm{cm}^{2}$, az árnyékos oldalán $0,2-3,16 \mathrm{~kg} / \mathrm{cm}^{2}$ voltak (25. ábra). 2011-ben mind a három érettségben a gyümölcs napos oldalán az 'Aurora' fajta gyümölcshúsa volt a legpuhább (70\%-os érettségben $1,3 \mathrm{~kg} / \mathrm{cm}^{2}, 80 \%$-os érettségben $0,7 \mathrm{~kg} / \mathrm{cm}^{2}, 90 \%$-os érettségben $0,1 \mathrm{~kg} / \mathrm{cm}^{2}$ ). Kiemelkedő húskeménységi értékeket a napos oldalon, 70\%-os érettségben a 'Goldrich' $\left(11 \mathrm{~kg} / \mathrm{cm}^{2}\right)$ és a 'Veecot' fajta $\left(8,04 \mathrm{~kg} / \mathrm{cm}^{2}\right)$ esetében mértünk (24. ábra). 2013-ban 70\%-os érettségben a napos oldalon a 'Sylvercot' fajta gyümölcsi voltak a legpuhábbak (1,6 $\left.\mathrm{kg} / \mathrm{cm}^{2}\right)$, míg a 'Veecot' fajta gyümölcsi a legkeményebbek $\left(5,8 \mathrm{~kg} / \mathrm{cm}^{2}\right)$ (25. ábra). Mind a két évben, a gyümölcs napos oldalán, $80 \%$ és 90\%-os érettségben az 'Orange Red' fajta gyümölcseinél mértünk kiemelkedő húskeménységi értékeket. A legtöbb külföldi fajta ('Bergarouge', 'Goldrich', 'Harcot', 'Harogem', 'Pinkcot', 'Sylvercot') húskeménysége esetében minden érettségi állapotban szignifikáns különbséget tudtunk kimutatni az évek között, míg az 'Aurora' fajta esetében 70\%-os érettségben, a gyümölcsök árnyékos oldalán volt csak szignifikáns a különbség (M.2.15. táblázat) 


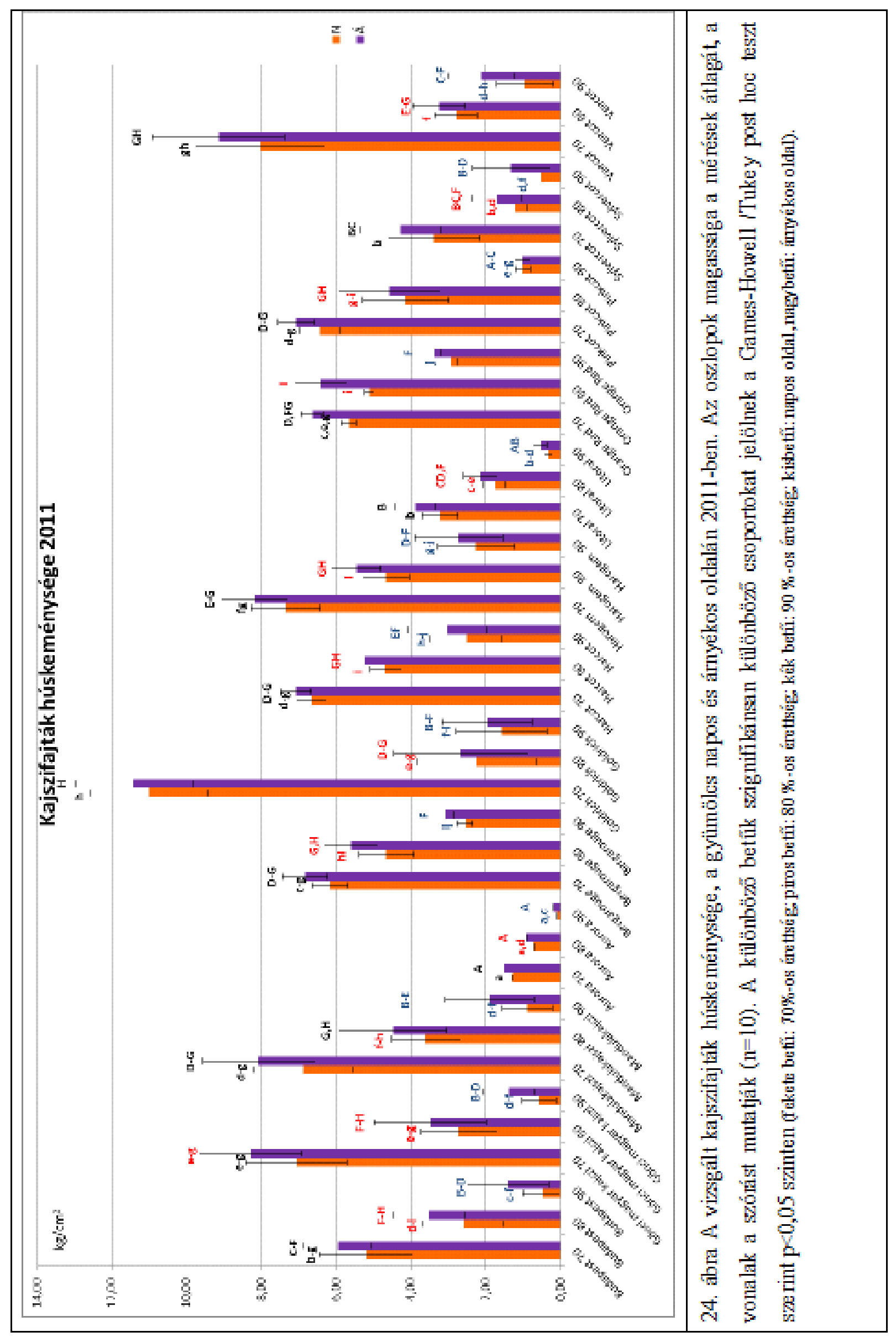




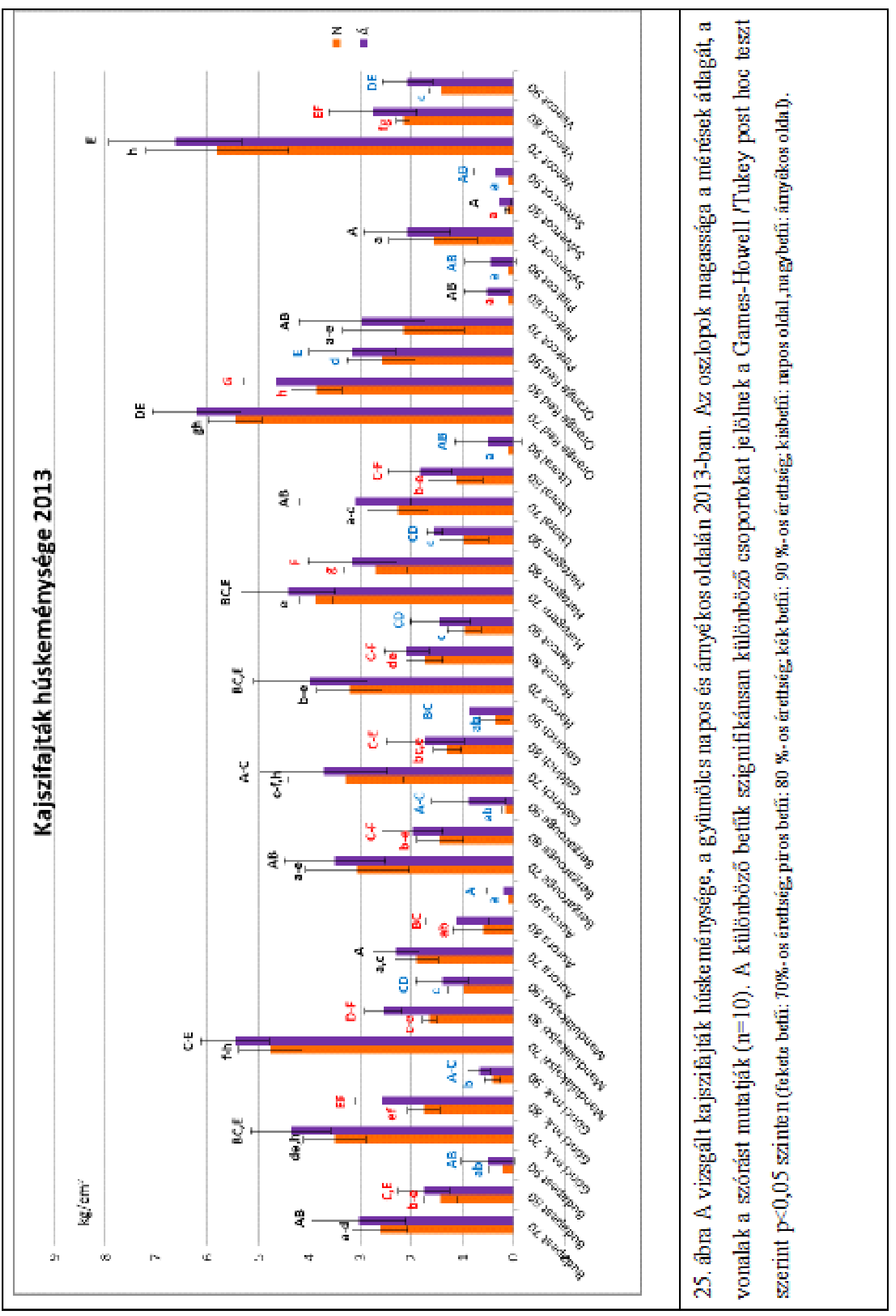


A páros t-próba alapján szignifikáns különbséget tudtunk kimutatni a gyümölcs napos és árnyékos oldalán mért húskeménységi értékek között $\left(t_{\mathrm{hk}}(814)=-28,86 ; \mathrm{p}<0,001\right)$.

\subsubsection{Kajszifajták húskeménységének és állományparamétereinek vizsgálata müszeres méréssel}

2011-ben a kiválasztott kajszifajták ('Budapest', 'Ceglédi arany', 'Gönci magyar kajszi', 'Hargrand', 'Harlayne', 'Harogem', 'Laycot', 'Mandulakajszi', 'Veecot') esetében három különböző mérési módszerrel határoztuk meg húskeménységük alakulását a különböző érettségi stádiumokban. A kézi penetrométerrel és a Texture Analyzer müszer TA 44-es mérőfejével végzett vizsgálatok eredményeit az 26. és a 27. ábrán tüntettük föl. A kézi penetrométer mérőfeje nagyobb felületü volt, mint a Texture Analyzer- é. A mérési eredmények alapján a húskeménységet mindkét ábrán $\mathrm{kg} / \mathrm{cm}^{2}$-ben adtuk meg, így az adatok összehasonlíthatók. A két mérési módszerrel hasonló eredményeket kaptunk. A fajták között hasonló különbségeket, az érés során hasonló tendenciákat mutatott ki mindkét módszer. A húskeménységi értékekben 45\%-os, esetenként 10-15\%-os eltérés volt a két módszerrel történt mérés eredményei között. Ezek abból adódtak, hogy az eltérő méretű mérőfejeknél különböző a hús közvetlen roncsolásából és a mérőtest oldalához való tapadásból származó ellenállás aránya. Minden esetben a kézi penetrométerrel kaptunk kisebb húskeménységi értékeket. A Texture Analyzerrel mért értékeket fogadjuk el pontosabbnak, és ezek alapján hasonlítjuk össze a fajtákat és az érettségi állapotokat.

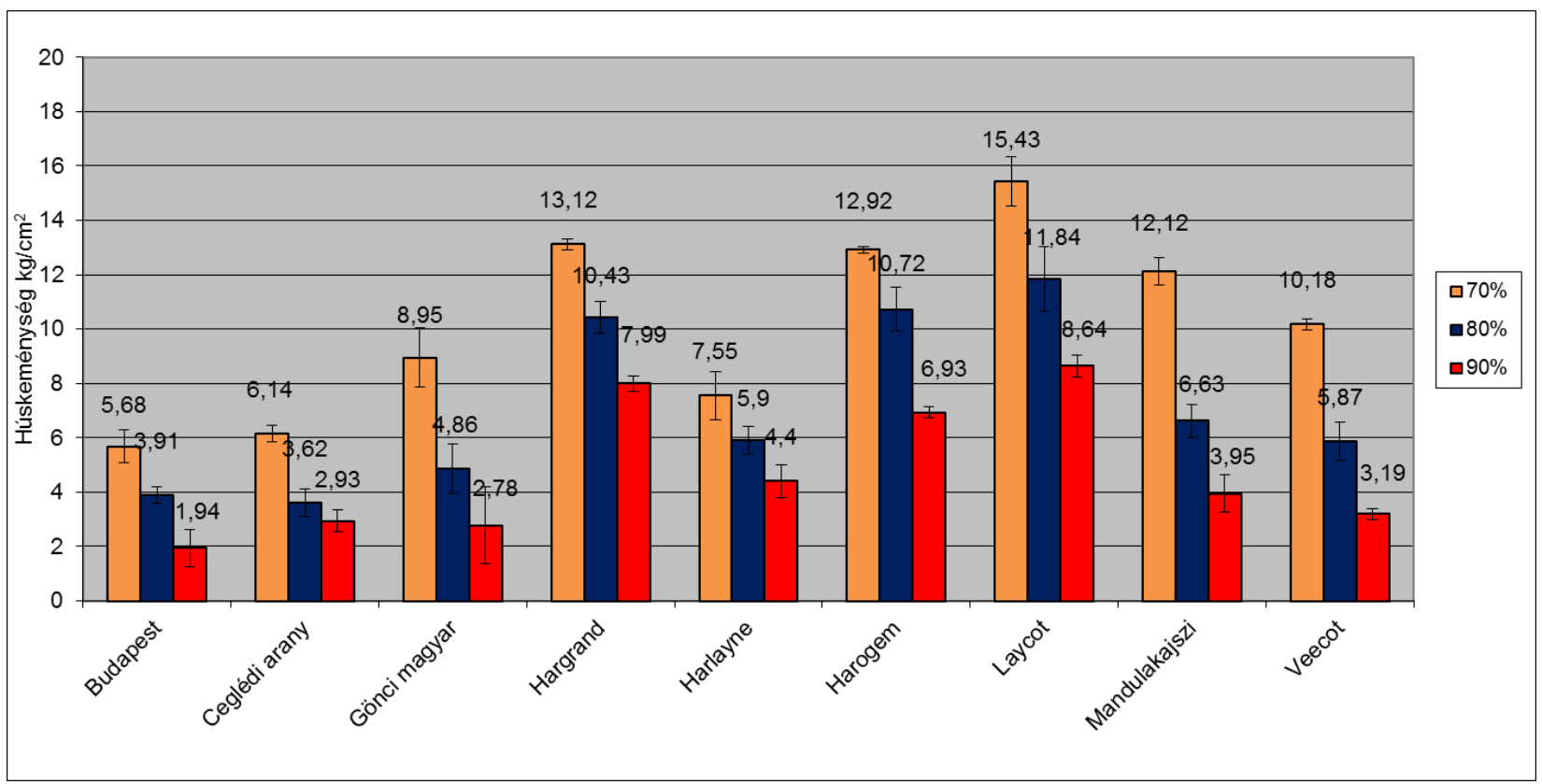

26. ábra: A vizsgált kajszifajták átlagos húskeménysége 2011-ben, kézi penetrométerrel mérve. 


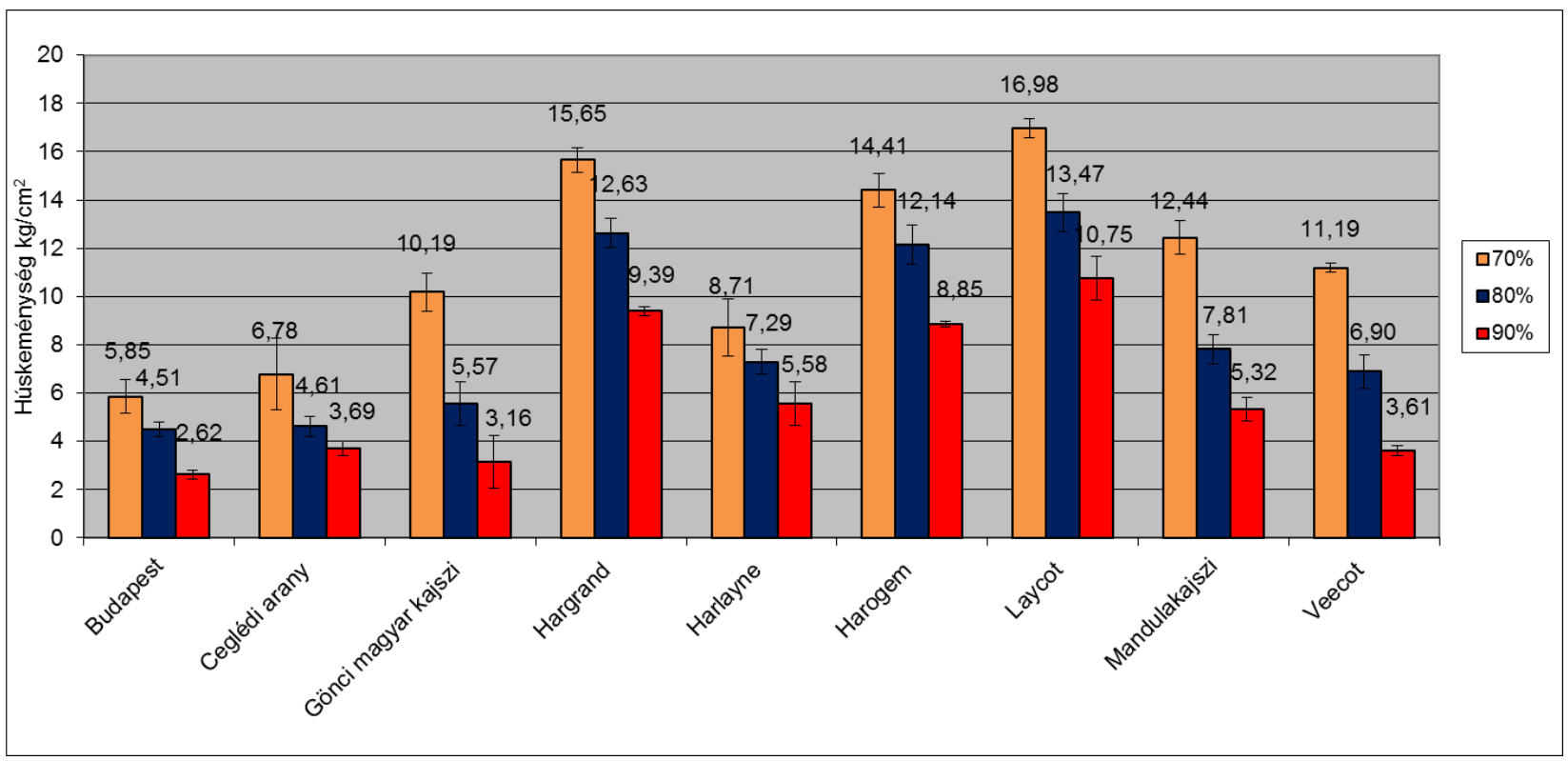

27. ábra: A vizsgált kajszifajták átlagos húskeménysége 2011-ben, müszerrel, TA44 típusú próbatesttel méve.

A fajták között jelentős különbségeket találtunk, mind a húskeménység 70\%-os érettségben mért kezdeti értéke, mind az érés során bekövetkezett változása között. A hagyományos magyar fajták közül a 'Budapest' és a 'Ceglédi arany' gyümölcsei voltak a legpuhábbak, 70\%-os érettségben 5,85 illetve $6,78 \mathrm{~kg} / \mathrm{cm}^{2}$ húskeménységüek. A másik két magyar fajta, a 'Gönci magyar kajszi' és a 'Mandulakajszi' gyümölcsei kezdetben jóval keményebbek voltak $\left(10,19\right.$ és $\left.12,44 \mathrm{~kg} / \mathrm{cm}^{2}\right)$, de gyorsabban puhultak az érés során, mint a másik két magyar fajta gyümölcsei. A ‘Ceglédi arany’ fajta húskeménysége 45\%-al csökkent a $70 \%$ és a 90\%-os érettség között, a 'Gönci magyar kajszi' húskeménysége viszont e két érettségi állapot között 69\%-al csökkent, és 90\%-os érettségben puhábbak voltak a gyümölcsei, mint a 'Ceglédi arany' fajtáé. A 'Mandulakajszi' gyümölcsei is gyors ütemben puhultak, 90\%-os érettségben $57 \%$-al voltak puhábbak, mint 70\%-os érettségben, de még így is ez volt a legkeményebb húsú a vizsgált magyar fajták közül, és $90 \%$-os érettségben is $5,32 \mathrm{~kg} / \mathrm{cm}^{2}$ volt a húskeménysége. Az összes vizsgált fajta közül a 'Laycot' gyümölcseinek húskeménysége volt a legmagasabb mindegyik érettségi állapotban. A három legkeményebb húsú fajta ('Hargrand', 'Harogem' és 'Laycot') húskeménysége kisebb ütemben csökkent az érés során, mint a magyar fajtáké, így ezeknél a fajtáknál még 90\%-os érettségben is $9-10 \mathrm{~kg} / \mathrm{cm}^{2}$ értékeket mértünk, gyümölcseik ebben az érettségben is keményebbek voltak, mint magyar fajtáké 70-80\%-os érettségben. A vizsgált külföldi fajták közül a 'Veecot' húskeménységének alakulása közel azonos volt a 'Mandulakajszi'-éval. A 'Harlayne' húskeménysége padig a 'Gönci magyar kajszi’-éhoz hasonlóan alakult, csak attól lassúbb ütemben puhultak a gyümölcsei. 
A TA 9 típusú, tủ alakú mérőfejjel végzett vizsgálatok eredményeit a 28. ábrán tüntettük föl. Ez a vizsgálat az előző két vizsgálati módszerrel mért eredményekhez teljesen hasonló tendenciákat mutatott ki. Kisebb különbségek abból adódtak, hogy itt a mérőfej felülete nagyon kicsi, tüszerü, viszont a behatolás során a gyümölcsszövetek tapadása a méröelem oldalához nagyobb szerepet játszik, mint az előző vizsgálati módszereknél. A keménység értékét itt grammban adjuk meg, ami a tü tejes behatolásához szüksége legnagyobb erőt jelenti.

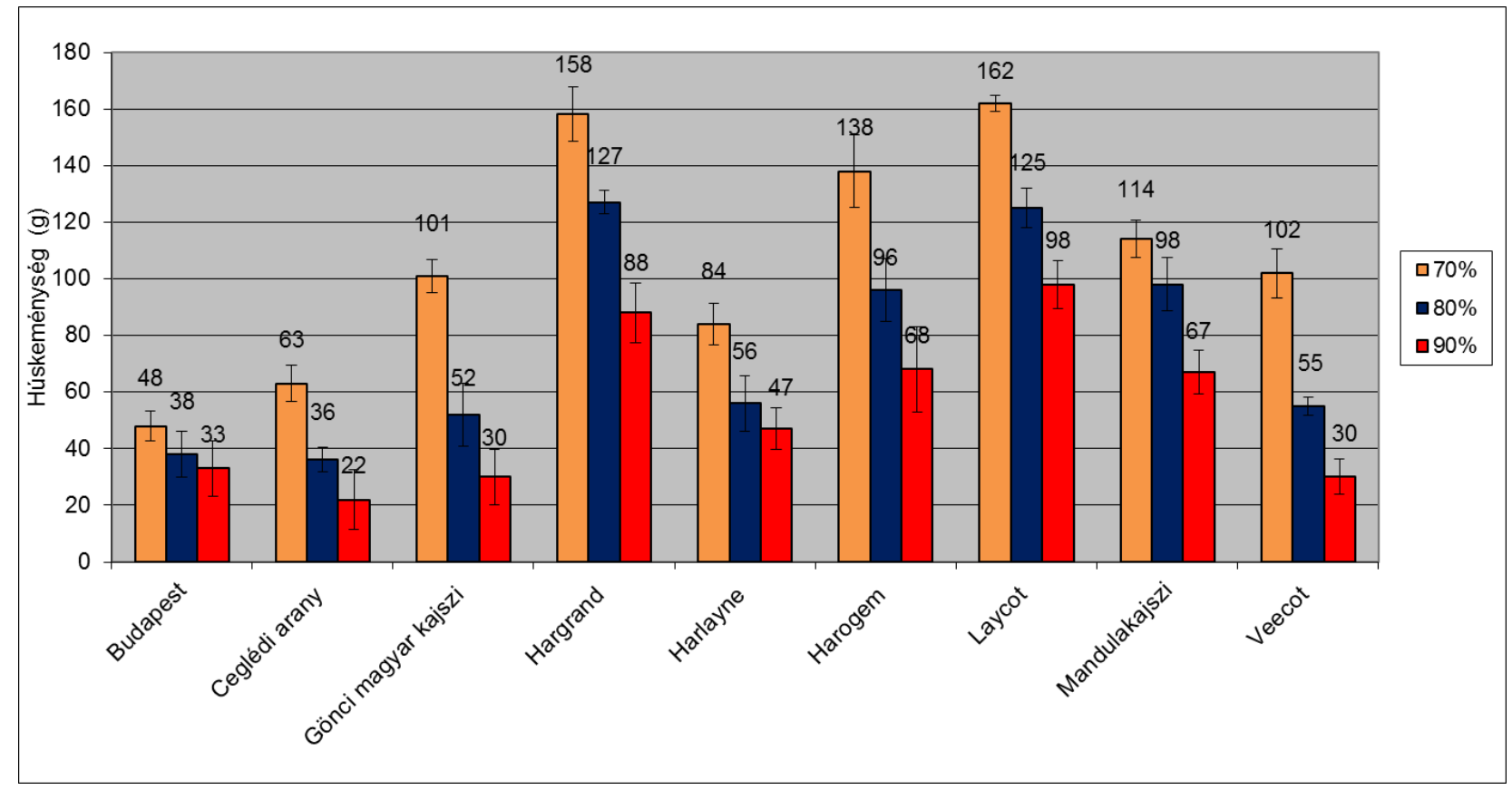

28. ábra: A vizsgált kajszifajták átlagos húskeménysége 2011-ben, müszerrel, TA9 típusú próbatesttel méve.

A 2013-as évben vizsgáltuk 8 ígéretes külföldi kajszifajta ('Litoral', 'Pinkcot', 'Sylvercot', 'Goldrich', 'Bergarouge', 'Harcot', 'Orange Red', 'Veecot') és kontroll fajtaként a 'Gönci magyar kajszi' állományparamétereinek alakulását közvetlenül a szüret után. A müszeres méréseket a TA9 típusú próbatesttel végeztük, mert ezzel a módszerrel pontosabb húskeménységi értékeket kaptunk, s lehetőségünk nyílt a tü kétszeri behatolása után a húskeménységen kívül más állományjellemző paraméterek vizsgálatára is. A müszeres mérés során, a fajták húskeménységének alakulása tekintetében, a penetrométeres mérésekhez hasonló tendenciát tudtunk kimutatni.

Az egytényezős többváltozós variancianalízis (8. modell) alapján állíthatjuk, hogy a vizsgált évben, mind a három érettségi állapotban szignifikáns fajtahatást tudtunk kimutatni. A szignifikáns fajtahatás minden változóban kimutatható volt, kivételt képezett a 90\%-os érettség, ahol a gyümölcsök árnyékos oldalán nem találtunk a kohéziós erő tekintetében szignifikáns különbséget a fajták között (M.2.16. táblázat). 
A Tukey/Games Howell-féle post hoc teszt alapján a fajták húskeménységének és állományparamétereinek alakulása tekintetében szignifikáns különbségeket tudtunk kimutatni. Eredményeinkböl megállapítható, hogy a külföldi fajták mindegyike keményebb volt a kontrollként használt magyar fajtához képest (29. ábra). Kiemelkedő húskeménység értékeket 70\%-os érettségben az 'Orange Red' (napos oldal: 111,3 g, árnyékos oldal: 139,5 g) és a 'Veecot' (napos oldal: 123,6 g, árnyékos oldal: 138,3 g) fajtáknál mértünk. Az 'Orange Red' fajta húskeménysége kisebb ütemben csökkent az érés során, mint a magyar fajtáé, így ennél a fajtánál még 90\%-os érettségben is a gyümölcs napos oldalán átlagosan 54,4 g, az árnyékos oldalon 76,7 g értékeket mértünk, vagyis gyümölcsei ebben az érettségben is keményebb volt, mint a magyar fajta 70 illetve $80 \%$-os érettségben. A külföldi fajták közül a 'Litoral' gyümölcsei voltak a legpuhábbak, 70\%-os érettségben átlagosan, a gyümölcs napos oldalán 41,4 g, árnyékos oldalán 65,8 g húskeménységü volt.

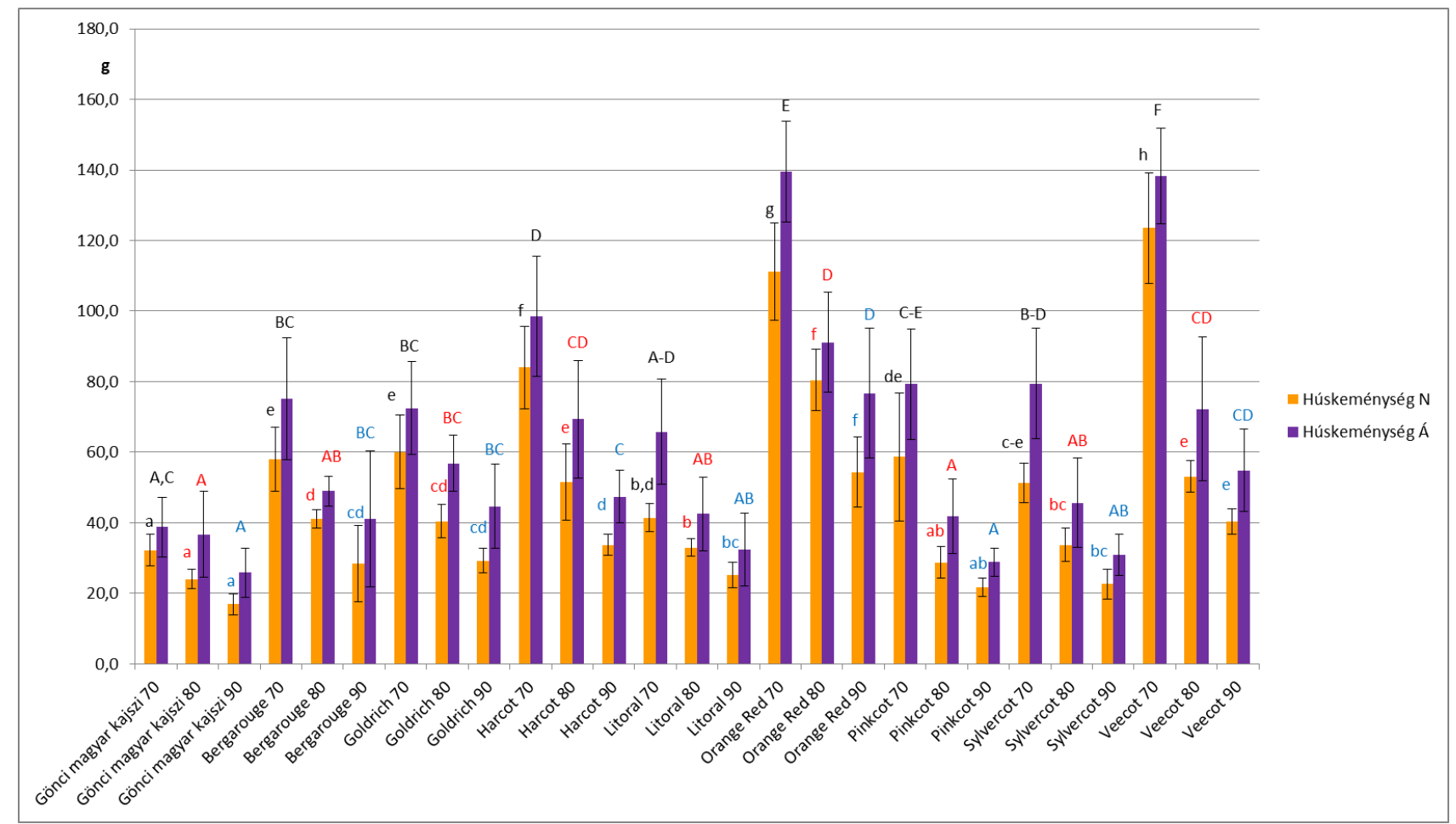

29. ábra: A vizsgált kajszifajták gyümölcseinek húskeménysége müszerrel mérve 2013-ban. Az oszlopok magassága a mérések átlagát, a vonalak a szórást mutatják $(\mathrm{n}=10)$. A különböző betük szignifikánsan különböző csoportokat jelölnek a Games-Howell- /Tukey-féle post hoc teszt szerint $\mathrm{p}<0,05$ szinten (fekete betü: 70\%-os érettség; piros betü: 80\%-os érettség; kék betü: 90\%-os érettség; kisbetü: napos oldal, nagybetü: árnyékos oldal).

A TA 9 mérőfejjel végzett vizsgálatok előnye, hogy a tủ másodszori behatolása után a húskeménységen kívül más állományjellemző paramétereket is meg tudunk határozni. Az adhézió, a kohézió, és a rágási energiaszükséglet, mint a húskeménység mellett a három 
legjellemzőbb paraméter értékeit a 16,17, 18, 19, 20. és 21. táblázatban adjuk meg a különböző érettségi állapotokra vonatkozóan.

Az idegen testhez való tapadás, vagyis adhézió mértéke (16. és 17. táblázat) az érés elörehaladtával folyamatosan csökkent. 70\%-os érettségben, a gyümölcs napos oldalán 0,43-1,58 mJ, az árnyékos oldalán 0,47-2,2 mJ volt ez az érték. 80\%-os érettségben, a gyümölcs napos oldalán 0,34-1,06 mJ, az árnyékos oldalán 0,4-1,2 mJ, 90\%-os érettségben pedig, a gyümölcs napos oldalán $0,26-0,66 \mathrm{~mJ}$, az árnyékos oldalán $0,34-0,8 \mathrm{~mJ}$ volt az adhéziós erő mértéke. 70\% és $80 \%$-os érettségben, valamint 90\%-os érettségben a gyümölcs árnyékos oldalán az 'Orange Red' fajtánál volt a legmagasabb az adhézió mértéke 1,56 mJ és 1,06 mJ értékkel a gyümölcs napos oldalán és 2,2 mJ,1,2 mJ, illetve $0,8 \mathrm{~mJ}$ értékkel a gyümölcs árnyékos oldalán. 90\%-os érettségben, a gyümölcs napos oldalán a 'Veecot' fajtánál volt a legmagasabb ez az érték, 0,66 $\mathrm{mJ}$.

16. táblázat: Az adhéziós erő $(\mathrm{mJ})$ mértékének változása az érés során a gyümölcs napos oldalán vizsgálva a vizsgálatba vont 9 kajszifajtánál

\begin{tabular}{cccc}
\hline Fajták & \multicolumn{3}{c}{ Adhéziós erö (mJ) Napos oldal } \\
\cline { 2 - 4 } & $\mathbf{7 0 \% - o s ~ e ́ r e t t s e ́ g ~}$ & $\mathbf{8 0 \% - 0 s ~ e ́ r e t t s e ́ g ~}$ & $\mathbf{9 0 \% - 0 s ~ e ́ r e t t s e ́ g ~}$ \\
\hline Gönci magyar kajszi & $0,43 \pm 0,12 \mathrm{a}$ & $0,34 \pm 0,07 \mathrm{a}, \mathrm{c}$ & $0,26 \pm 0,1 \mathrm{a}$ \\
Bergarouge & $0,65 \pm 0,17 \mathrm{a}-\mathrm{c}$ & $0,45 \pm 0,1 \mathrm{~cd}$ & $0,33 \pm 0,14 \mathrm{a}$ \\
Goldrich & $0,69 \pm 0,15 \mathrm{bc}$ & $0,47 \pm 0,09 \mathrm{~d}$ & $0,36 \pm 0,08 \mathrm{a}$ \\
Harcot & $1,05 \pm 0,19 \mathrm{~d}$ & $0,71 \pm 0,12 \mathrm{e}$ & $0,53 \pm 0,08 \mathrm{~b}$ \\
Litoral & $0,53 \pm 0,07 \mathrm{ab}$ & $0,43 \pm 0,05 \mathrm{~b}-\mathrm{d}$ & $0,38 \pm 0,06 \mathrm{a}$ \\
Orange Red & $1,56 \pm 0,18 \mathrm{e}$ & $1,06 \pm 0,27 \mathrm{f}$ & $0,64 \pm 0,14 \mathrm{~b}$ \\
Pinkcot & $0,77 \pm 0,25 \mathrm{bc}$ & $0,36 \pm 0,08 \mathrm{a}-\mathrm{d}$ & $0,31 \pm 0,08 \mathrm{a}$ \\
Sylvercot & $0,79 \pm 0,15 \mathrm{c}$ & $0,43 \pm 0,11 \mathrm{~cd}$ & $0,32 \pm 0,1 \mathrm{a}$ \\
Veecot & $1,58 \pm 0,26 \mathrm{f}$ & $0,73 \pm 0,08 \mathrm{ef}$ & $0,66 \pm 0,1 \mathrm{~b}$ \\
\hline
\end{tabular}

A különböző betük szignifikánsan különböző csoportokat jelölnek a Games-Howell- /Tukey-féle post hoc teszt szerint p<0,05 szinten (fekete betü: 70\%-os érettség; piros betü: 80\%-os érettség; kék betü: 90\%-os érettség). 
17. táblázat: Az adhéziós erő mértékének változása az érés során a gyümölcs árnyékos oldalán vizsgálva a vizsgálatba vont 9 kajszifajtánál

\begin{tabular}{cccc}
\hline Fajták & \multicolumn{3}{c}{ Adhéziós erö (mJ) Árnyékos oldal } \\
\cline { 2 - 4 } & $\mathbf{7 0 \% - 0 s ~ e ́ r e t t s e ́ g ~}$ & $\mathbf{8 0 \% - o s ~ e ́ r e t t s e ́ g ~}$ & $\mathbf{9 0 \% - o s ~ e ́ r e t t s e ́ g ~}$ \\
\hline Gönci magyar kajszi & $0,47 \pm 0,17 \mathrm{a}, \mathrm{c}$ & $0,404 \pm 0,15 \mathrm{a}$ & $0,35 \pm 0,07 \mathrm{a}$ \\
Bergarouge & $0,8 \pm 0,19 \mathrm{bc}$ & $0,62 \pm 0,14 \mathrm{ab}$ & $0,49 \pm 0,23 \mathrm{a}-\mathrm{c}$ \\
Goldrich & $0,77 \pm 0,17 \mathrm{bc}$ & $0,58 \pm 0,13 \mathrm{ab}$ & $0,49 \pm 0,14 \mathrm{ab}$ \\
Harcot & $1,3 \pm 0,22 \mathrm{~d}$ & $0,9 \pm 0,22 \mathrm{c}$ & $0,66 \pm 0,09 \mathrm{bc}$ \\
Litoral & $0,64 \pm 0,15 \mathrm{a}-\mathrm{c}$ & $0,49 \pm 0,04 \mathrm{a}$ & $0,4 \pm 0,11 \mathrm{a}$ \\
Orange Red & $2,2 \pm 0,4 \mathrm{e}$ & $1,2 \pm 0,26 \mathrm{c}$ & $0,8 \pm 0,2 \mathrm{c}$ \\
Pinkcot & $0,98 \pm 0,44 \mathrm{~cd}$ & $0,5 \pm 0,16 \mathrm{a}$ & $0,34 \pm 0,06 \mathrm{a}$ \\
Sylvercot & $0,99 \pm 0,32 \mathrm{~b}-\mathrm{d}$ & $0,56 \pm 0,23 \mathrm{ab}$ & $0,36 \pm 0,09 \mathrm{a}$ \\
Veecot & $1,73 \pm 0,31 \mathrm{e}$ & $0,96 \pm 0,31 \mathrm{bc}$ & $0,72 \pm 0,14 \mathrm{c}$ \\
\hline
\end{tabular}

A különbözö betük szignifikánsan különböző csoportokat jelölnek a Games-Howell- /Tukey-féle post hoc teszt szerint $\mathrm{p}<0,05$ szinten (fekete betü: 70\%-os érettség; piros betü: $80 \%$-os érettség; kék betủ: $90 \%$-os érettség).

A sejteket összetartó kohéziós erő mértékét a 18. és 19. táblázatokban szemléltettük. 70\%-os érettségben, a gyümölcs napos oldalán 0,19-0,24 mJ, az árnyékos oldalán 0,19-0,31 mJ volt ez az érték. 80\%-os érettségben, a gyümölcs napos oldalán 0,195-0,24 mJ, az árnyékos oldalán 0,204-0,24 mJ, 90\%-os érettségben pedig, a gyümölcs napos oldalán 0,14-0,27 mJ, az árnyékos oldalán 0,2-1,023 mJ volt a kohéziós erő mértéke. 80\%-os érettségben a gyümölcsök napos oldalán nem találtunk szignifikáns különbséget a fajták között. 70\%-os érettségben a gyümölcsök árnyékos oldalát vizsgálva a kajszifajták azonos statisztikai csoportba voltak sorolhatók, kivéve az 'Orange Red' fajtát, amelynél 0,31 mJ volt a kohéziós erő mértéke. 90\%os érettségben a gyümölcs napos oldalán, a legmagasabb értéket a 'Pinkcot' (0,27 mJ) fajtánál mértük.

18. táblázat: A kohéziós erő $(\mathrm{mJ})$ mértékének változása az érés során a gyümölcs napos oldalán vizsgálva a vizsgálatba vont 9 kajszifajtánál

\begin{tabular}{cccc}
\hline Fajták & \multicolumn{3}{c}{ Kohéziós erö (mJ) Napos oldal } \\
\cline { 2 - 4 } & $\mathbf{7 0 \% - o s ~ e ́ r e t t s e ́ g ~}$ & $\mathbf{8 0 \% - 0 s ~ e ́ r e t t s e ́ g ~}$ & $\mathbf{9 0 \% - 0 s ~ e ́ r e t t s e ́ g ~}$ \\
\hline Gönci magyar kajszi & $0,24 \pm 0,03 \mathrm{c}$ & $0,23 \pm 0,04 \mathrm{a}$ & $0,14 \pm 0,03 \mathrm{a}$ \\
Bergarouge & $0,23 \pm 0,03 \mathrm{ab}$ & $0,22 \pm 0,02 \mathrm{a}$ & $0,19 \pm 0,06 \mathrm{a}-\mathrm{c}$ \\
Goldrich & $0,19 \pm 0,018 \mathrm{a}$ & $0,21 \pm 0,01 \mathrm{a}$ & $0,2 \pm 0,01 \mathrm{a}$ \\
Harcot & $0,203 \pm 0,01 \mathrm{ab}$ & $0,21 \pm 0,02 \mathrm{a}$ & $0,24 \pm 0,02 \mathrm{~cd}$ \\
Litoral & $0,2 \pm 0,02 \mathrm{a}$ & $0,2 \pm 0,02 \mathrm{a}$ & $0,2 \pm 0,012 \mathrm{ab}$ \\
Orange Red & $0,24 \pm 0,01 \mathrm{bc}$ & $0,21 \pm 0,05 \mathrm{a}$ & $0,24 \pm 0,02 \mathrm{~cd}$ \\
Pinkcot & $0,2 \pm 0,02 \mathrm{a}$ & $0,24 \pm 0,05 \mathrm{a}$ & $0,27 \pm 0,07 \mathrm{~d}$ \\
Sylvercot & $0,2 \pm 0,02 \mathrm{a}$ & $0,21 \pm 0,03 \mathrm{a}$ & $0,22 \pm 0,06 \mathrm{bc}$ \\
Veecot & $0,22 \pm 0,03 \mathrm{a}-\mathrm{c}$ & $0,21 \pm 0,02 \mathrm{a}$ & $0,24 \pm 0,02 \mathrm{~cd}$ \\
\hline
\end{tabular}

A különböző betük szignifikánsan különböző csoportokat jelölnek a Games-Howell- /Tukey-féle post hoc teszt szerint p $<0,05$ szinten (fekete betű: 70\%-os érettség; piros betű: 80\%-os érettség; kék betü: 90\%-os érettség). 
19. táblázat: A kohéziós erő $(\mathrm{mJ})$ mértékének változása az érés során a gyümölcs árnyékos oldalán vizsgálva a vizsgálatba vont 9 kajszifajtánál

\begin{tabular}{cccc}
\hline Fajták & \multicolumn{3}{c}{ Kohéziós erö $(\mathbf{m J})$ Árnyékos oldal } \\
\cline { 2 - 4 } & $\mathbf{7 0 \% - o s ~ e ́ r e t t s e ́ g ~}$ & $\mathbf{8 0 \% - 0 s ~ e ́ r e t t s e ́ g ~}$ & $\mathbf{9 0 \% - 0 s ~ e ́ r e t t s e ́ g ~}$ \\
\hline Gönci magyar kajszi & $0,22 \pm 0,02 \mathrm{a}$ & $0,22 \pm 0,02 \mathrm{ab}$ & $0,22 \pm 0,03 \mathrm{c}$ \\
Bergarouge & $0,19 \pm 0,02 \mathrm{a}$ & $0,21 \pm 0,02 \mathrm{a}$ & $0,2 \pm 0,07 \mathrm{a}-\mathrm{c}$ \\
Goldrich & $0,2 \pm 0,02 \mathrm{a}$ & $0,21 \pm 0,018 \mathrm{ab}$ & $0,22 \pm 0,018 \mathrm{a}-\mathrm{c}$ \\
Harcot & $0,22 \pm 0,02 \mathrm{a}$ & $0,21 \pm 0,02 \mathrm{ab}$ & $0,23 \pm 0,03 \mathrm{a}-\mathrm{c}$ \\
Litoral & $0,19 \pm 0,03 \mathrm{a}$ & $0,2 \pm 0,01 \mathrm{a}$ & $0,21 \pm 0,01 \mathrm{a}, \mathrm{c}$ \\
Orange Red & $0,31 \pm 0,05 \mathrm{~b}$ & $0,24 \pm 0,02 \mathrm{~b}$ & $0,23 \pm 0,01 \mathrm{a}-\mathrm{c}$ \\
Pinkcot & $0,21 \pm 0,02 \mathrm{a}$ & $0,22 \pm 0,03 \mathrm{ab}$ & $0,23 \pm 0,04 \mathrm{c}$ \\
Sylvercot & $0,21 \pm 0,03 \mathrm{a}$ & $0,21 \pm 0,01 \mathrm{a}$ & $0,22 \pm 0,02 \mathrm{a}-\mathrm{c}$ \\
Veecot & $0,21 \pm 0,03 \mathrm{a}$ & $0,22 \pm 0,02 \mathrm{ab}$ & $0,23 \pm 0.01 \mathrm{bc}$ \\
\hline
\end{tabular}

A különböző betük szignifikánsan különböző csoportokat jelölnek a Games-Howell- /Tukey-féle post hoc teszt szerint p $<0,05$ szinten (fekete betü: 70\%-os érettség; piros betü: 80\%-os érettség; kék betü: 90\%-os érettség).

A rágási energiaszükséglet (20. és 21. táblázat) az érés folyamán folyamatosan csökkent. 70\%-os érettségben, a gyümölcs napos oldalán 0,41-1,83 mJ, az árnyékos oldalán 0,44-2,09 mJ volt ez az érték. 80\%-os érettségben, a gyümölcs napos oldalán 0,27-0,99 mJ, az árnyékos oldalán 0,44-1,06 mJ, 90\%-os érettségben pedig, a gyümölcs napos oldalán 0,1-0,76 mJ, az árnyékos oldalán 0,3-1,01 mJ volt a rágási energiaszükséglet. Legmagasabb értékkel az 'Orange Red' és a 'Veecot' fajta rendelkezett. Legkisebb rágási energiaszükséglete, mind a három érettségi stádiumban, a gyümölcs napos oldalán és árnyékos oldalán egyaránt a 'Gönci magyar kajszi’ fajtának volt.

20. táblázat: A rágási energiaszükséglet $(\mathrm{mJ})$ mértékének változása az érés során a gyümölcs napos oldalán vizsgálva a vizsgálatba vont 9 kajszifajtánál

\begin{tabular}{cccc}
\hline \multirow{2}{*}{ Fajták } & \multicolumn{3}{c}{ Rágási energiaszükséglet (mJ) Napos oldal } \\
\cline { 2 - 4 } & $\mathbf{7 0 \% - 0 s ~ e ́ r e t t s e ́ g ~}$ & $\mathbf{8 0 \% - o s ~ e ́ r e t t s e ́ g ~}$ & $\mathbf{9 0 \% - o s ~ e ́ r e t t s e ́ g ~}$ \\
\hline Gönci magyar kajszi & $0,41 \pm 0,07 \mathrm{a}$ & $0,27 \pm 0,08 \mathrm{a}$ & $0,1 \pm 0,09 \mathrm{a}$ \\
Bergarouge & $0,901 \pm 0,41 \mathrm{c}$ & $0,48 \pm 0,07 \mathrm{~cd}$ & $0,32 \pm 0,13 \mathrm{bc}$ \\
Goldrich & $0,66 \pm 0,15 \mathrm{c}$ & $0,45 \pm 0,07 \mathrm{bc}$ & $0,31 \pm 0,08 \mathrm{~b}$ \\
Harcot & $1,01 \pm 0,21 \mathrm{~d}$ & $0,63 \pm 0,19 \mathrm{de}$ & $0,44 \pm 0,07 \mathrm{~cd}$ \\
Litoral & $0,44 \pm 0,05 \mathrm{ab}$ & $0,34 \pm 0,06 \mathrm{a}$ & $0,25 \pm 0,05 \mathrm{~b}$ \\
Orange Red & $1,63 \pm 0,3 \mathrm{e}$ & $0,99 \pm 0,4 \mathrm{f}$ & $0,76 \pm 0,65 \mathrm{e}$ \\
Pinkcot & $0,64 \pm 0,25 \mathrm{bc}$ & $0,36 \pm 0,07 \mathrm{ab}$ & $0,32 \pm 0,14 \mathrm{~b}$ \\
Sylvercot & $0,57 \pm 0,09 \mathrm{c}$ & $0,39 \pm 0,11 \mathrm{a}-\mathrm{c}$ & $0,27 \pm 0,12 \mathrm{~b}$ \\
Veecot & $1,83 \pm 0,58 \mathrm{f}$ & $0,63 \pm 0,05 \mathrm{e}$ & $0,54 \pm 0,07 \mathrm{de}$ \\
\hline
\end{tabular}

A különböző betűk szignifikánsan különböző csoportokat jelölnek a Games-Howell- /Tukey-féle post hoc teszt szerint p<0,05 szinten (fekete betü: 70\%-os érettség; piros betü: 80\%-os érettség; kék betü: 90\%-os érettség). 
21. táblázat: A rágási energiaszükséglet $(\mathrm{mJ})$ mértékének változása az érés során a gyümölcs árnyékos oldalán vizsgálva a vizsgálatba vont 9 kajszifajtánál

\begin{tabular}{cccc}
\hline \multirow{2}{*}{ Fajták } & \multicolumn{3}{c}{ Rágási energiaszükséglet (mJ) Árnyékos oldal } \\
\cline { 2 - 4 } & $\mathbf{7 0 \% - 0 s ~ e ́ r e t t s e ́ g ~}$ & $\mathbf{8 0 \% - o s ~ e ́ r e t t s e ́ g ~}$ & $\mathbf{9 0 \% - o s ~ e ́ r e t t s e ́ g ~}$ \\
\hline Gönci magyar kajszi & $0,44 \pm 0,09 \mathrm{a}, \mathrm{c}$ & $0,44 \pm 0,19 \mathrm{a}$ & $0,3 \pm 0,12 \mathrm{a}$ \\
Bergarouge & $0,84 \pm 0,21 \mathrm{a}-\mathrm{d}$ & $0,57 \pm 0,09 \mathrm{a}$ & $0,53 \pm 0,3 \mathrm{ab}$ \\
Goldrich & $0,84 \pm 0,19 \mathrm{~b}-\mathrm{d}$ & $0,66 \pm 0,12 \mathrm{ab}$ & $0,52 \pm 0,16 \mathrm{ab}$ \\
Harcot & $1,29 \pm 0,21 \mathrm{e}$ & $0,85 \pm 0,22 \mathrm{~b}$ & $0,61 \pm 0,1 \mathrm{~b}$ \\
Litoral & $0,87 \pm 0,24 \mathrm{c}-\mathrm{e}$ & $0,46 \pm 0,11 \mathrm{a}$ & $0,36 \pm 0,15 \mathrm{a}$ \\
Orange Red & $3,4 \pm 0,57 \mathrm{f}$ & $1,6 \pm 0,7 \mathrm{c}$ & $1,01 \pm 0,34 \mathrm{c}$ \\
Pinkcot & $0,93 \pm 0,46 \mathrm{c}-\mathrm{e}$ & $0,51 \pm 0,16 \mathrm{a}$ & $0,34 \pm 0,05 \mathrm{a}$ \\
Sylvercot & $1,03 \pm 0,4 \mathrm{de}$ & $0,5 \pm 0,2 \mathrm{a}$ & $0,34 \pm 0,08 \mathrm{a}$ \\
Veecot & $2,09 \pm 0,53 \mathrm{f}$ & $0,91 \pm 0,25 \mathrm{~b}$ & $0,73 \pm 0,17 \mathrm{bc}$ \\
\hline
\end{tabular}

A különbözö betűk szignifikánsan különböző csoportokat jelölnek a Games-Howell- /Tukey-féle post hoc teszt szerint $\mathrm{p}<0,05$ szinten (fekete betü: 70\%-os érettség; piros betü: $80 \%$-os érettség; kék betü: $90 \%$-os érettség).

\subsection{A fogyasztói megítélést befolyásoló beltartalmi tényezők}

\subsubsection{Cukortartalom és összetevői}

\subsubsection{Vizoldható szárazanyagtartalom vizsgálata}

A kajszifajták vízoldható szárazanyagtartalma befolyásolja a minőségi megítélésüket. Vizsgálataink során két évjáratban $(2011,2013)$ határoztuk meg a vizsgálatba vont kajszifajták vízoldható szárazanyagtartalmát, amelyet Brix ${ }^{\circ}$-ban adtunk meg. Az eredmények alapján elmondható, hogy mind a két évben az érés elörehaladtával növekedett a vízoldható szárazanyagtartalma a gyümölcsöknek, illetve a gyümölcs napos oldalán magasabb refrakció értékeket mértünk, mint a gyümölcs árnyékos oldalán.

Annak meghatározására, hogy a vízoldható szárazanyagtartalmat szignifikáns módon befolyásolja-e a genotípus, illetve az évjárat hatása, kéttényezős kétváltozós varianciaanalízist végeztünk (9. modell, M.2.17. táblázat). A Wilk-féle lamba alapján elmondható, hogy a vízoldható szárazanyag-tartalomra szignifikánsan hat a fajta, valamint az év. A vizsgált két évben szignifikáns évjárathatást és fajtahatást tudtunk kimutatni mind a három érettségi állapotban, a gyümölcs napos és árnyékos oldalán egyaránt, emellett az interakció is szignifikánsnak bizonyult.

A szignifikáns interakció miatt a fajtahatást évenként, az évjárathatást pedig fajtánként elemeztük. A Tukey-/Games Howell-féle post hoc teszt alapján mindkét évben a fajták vízoldható szárazanyagtartalma alakulása tekintetében szignifikáns különbségeket tudtunk 
kimutatni. A 30. ábrán a vizsgált kajszifajták vízoldható szárazanyagtartalmának átlagértékeit ábrázoltuk 2011-ben, három érettségi stádiumban, a gyümölcs napos és árnyékos oldalán. 2011ben a gyümölcsök vízoldható szárazanyagtartalma 70\%-os érettségben, a gyümölcs napos oldalán: 11,75-14,82\%, az árnyékos oldalán: 10,92-13,56\%, volt, míg 80\%-os érettségben a napos oldalon: 12,95-17,88\%, az árnyékos oldalon: 12,51-16,61\% volt. 90\%-os érettségben pedig a gyümölcs napos oldalán: 13,55-19,71\%, az árnyékos oldalán: 13,7-17,83\% között alakult a refrakció mértéke. Míg 2013-ban ezek az értékek 70\%-os érettségben a gyümölcs napos oldalán: 10,85-15,8\%, az árnyékos oldalán 10,67-14,74\%; 80\%-os érettségben a napos oldalon: 11,7-18,84\%, az árnyékos oldalon: 11,1-17,4\% voltak. 90\%-os érettségben pedig a refrakció értéke a gyümölcs napos oldalán: 13,3-22,05\%, az árnyékos oldalán 13,1-19,4\% voltak (31. ábra). A legkisebb refrakció értékeket, 2011-ben mind a három érettségben az 'Orange Red', a 'Gönci magyar kajszi', az ‘Aurora', és a 'Sylvercot' fájtánál mértünk, míg 2013-ban az 'Aurora' és az 'Orange Red' fajtáknál. Kiemelkedő refrakció értékekkel a 'Budapest', a 'Mandulakajszi', a 'Bergarouge' és a 'Litoral' fajták rendelkeztek 2011-ben, míg 2013-ban a 'Veecot', a 'Litoral' és a 'Goldrich' fajták. Az évek között, minden érettségi stádiumban szignifikáns különbséget találtunk a 'Goldrich' és a 'Veecot' fajták esetében (M.2.18. táblázat). 


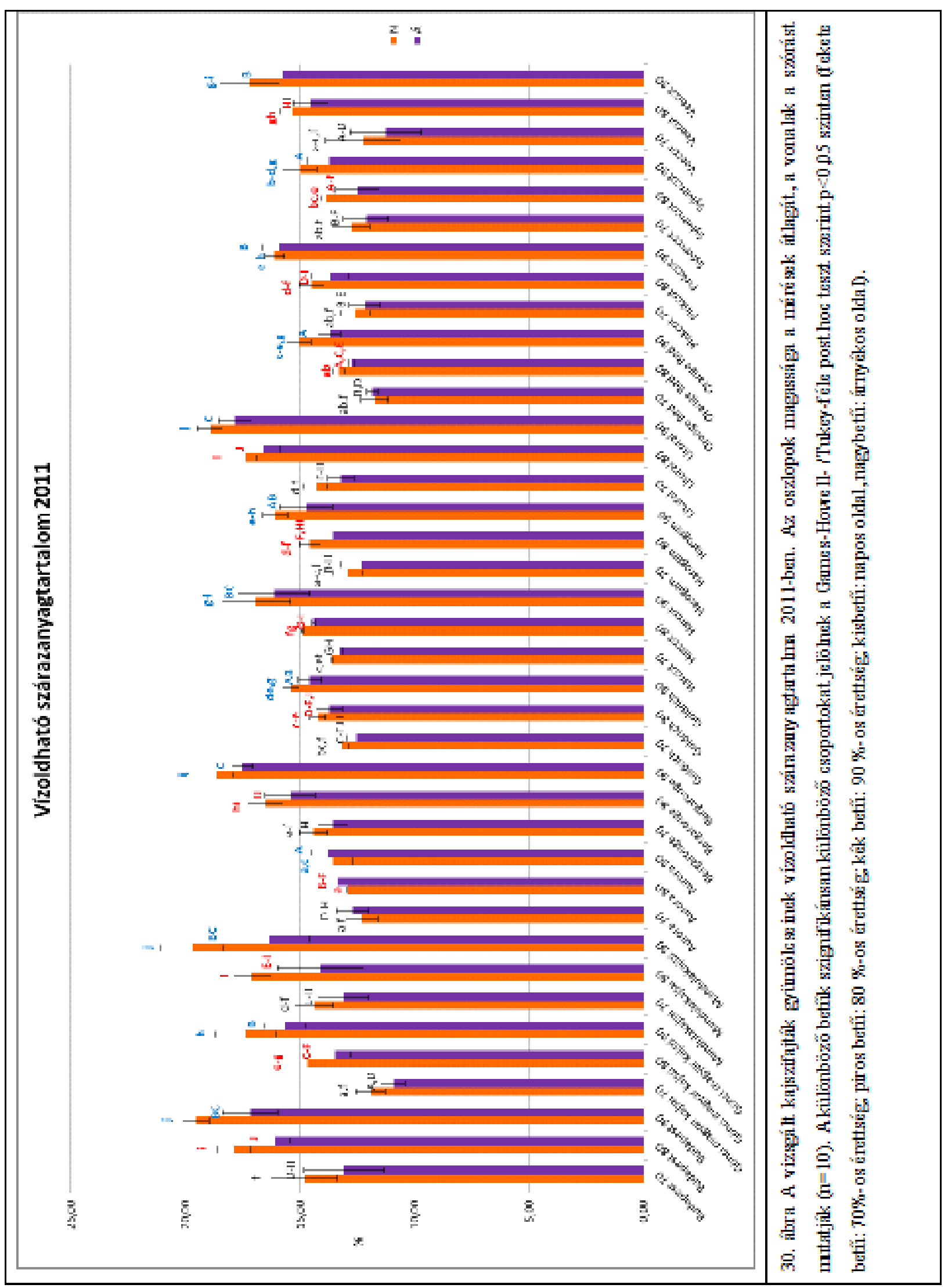




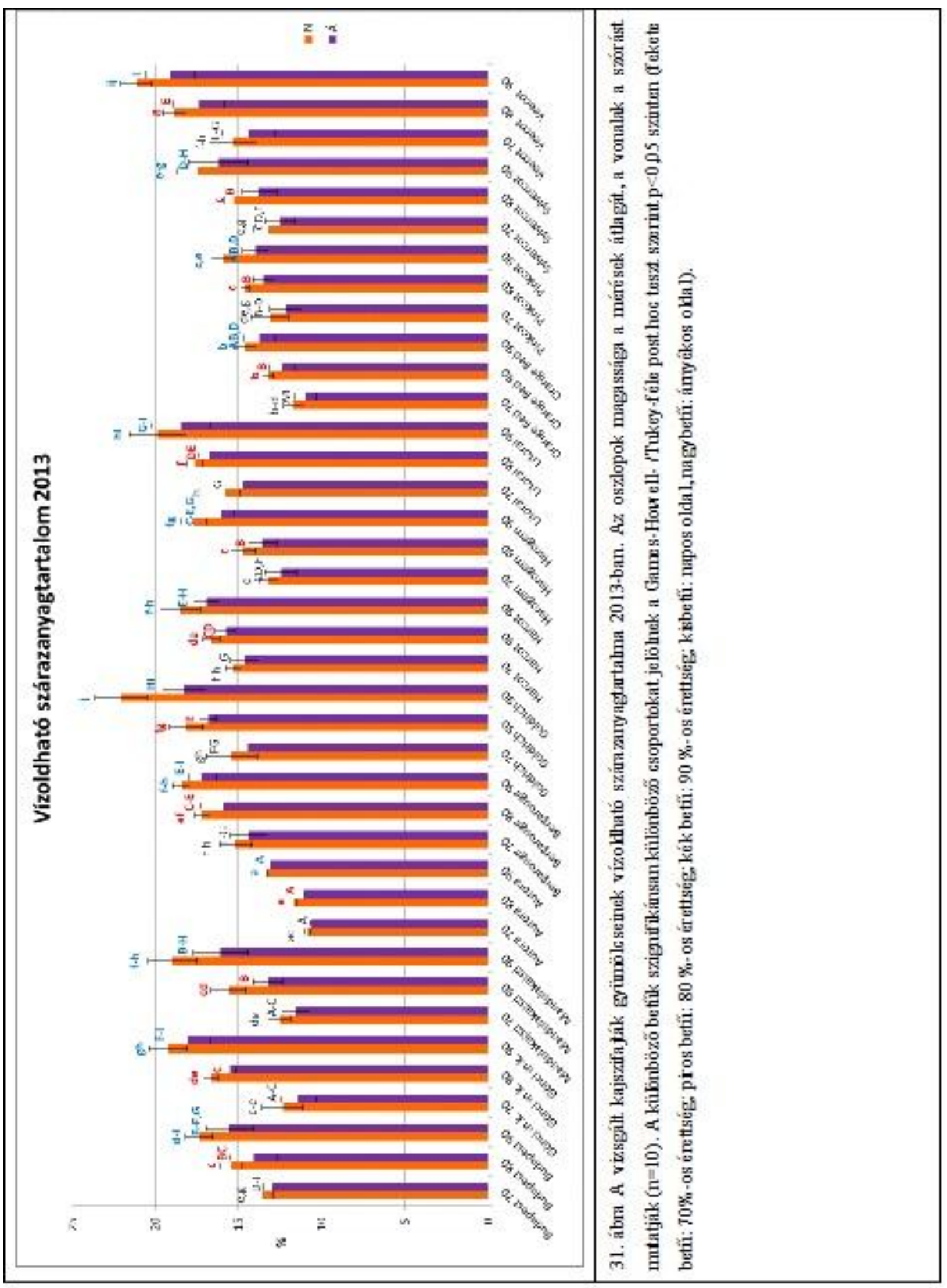


A páros t-próba alapján, a vízoldható szárazanyagtartam tekintetében a gyümölcs napos és árnyékos oldalán mért értékek között szignifikáns különbséget tudtunk kimutatni $\left(\mathrm{t}_{\mathrm{Bx}}(814)=29,96 ; \mathrm{p}<0,001\right)$.

\subsubsection{Cukorösszetvők}

HPLC berendezéssel megmértük a vizsgálatban vont kajszifajták közül hét fajta ('Gönci magyar kajszi', 'Goldrich', 'Sylvercot', 'Pinkcot', 'Harcot', 'Harogem', 'Veecot') cukorösszetevőinek (szacharóz, glükóz, fruktóz, D-szorbitol) alakulását 80\%-os érettségi stádiumban. A szénhidrátok kromatogramjáról minta a M.3.8. ábrán látható. A kéttényezős MANOVA (Wilk-féle lambda) alapján állíthatjuk, hogy a vizsgált két évben szignifikáns fajtahatást és évjárathatást tudtunk kimutatni (10. modell, M.2.19. táblázat). Továbbá elmondható, hogy a cukorösszetevőkre szignifikánsan hat a fajta és az év is. Az interakció is szignifikánsnak bizonyult, ezért a fajtahatást évenként, az évjárathatást pedig fajtánként elemeztük.

A Tukey-/Games-Howell-féle post hoc teszt alapján mind a két évben a cukorösszetevők alakulása tekintetében szignifikáns különbséget tudtunk kimutatni. A gyümölcsök cukortartalmának jelentős részét a szacharóz adta mind a két vizsgálati évben (22. és 23. táblázat). A 2013-as évben magasabb szacharóz tartalmat mértünk a fajtáknál, mint a 2011-es évben, kivétel ez alól a 'Pinkcot', mely esetében a 2011-es évben volt magasabb ez az érték. A 2011-es évben kiemelkedő szacharóztartalommal (10303 mg/100g) a 'Veecot' rendelkezett, legkisebbel pedig a 'Pinkcot' (5609 mg/100g). A 2013-as évben a 'Gönci magyar kajszi' -nál mértük a legmagasabb szacharóz értéket (17220 mg/100g), a legkisebbet pedig a 'Veecot'-nál (7911 mg/100g).

22. táblázat: 7 kajszifajta cukor komponenseinek alakulása (mg/100g) 80\%-os érettségben 2011 ben.

\begin{tabular}{ccccc}
\hline Év & \multicolumn{4}{c}{ 2011 } \\
\hline Fajta & szacharóz & glükóz & fruktóz & D-szorbitol \\
\hline Gönci magyar kajszi & $7960 \pm 74 \mathrm{c}$ & $2311 \pm 29 \mathrm{~d}$ & $1692 \pm 59 \mathrm{~d}$ & $181,5 \pm 16 \mathrm{a}$ \\
Sylvercot & $9581 \pm 53 \mathrm{e}$ & $1730 \pm 14 \mathrm{a}$ & $1120 \pm 17 \mathrm{a}$ & $220 \pm 10 \mathrm{~b}$ \\
Goldrich & $10175 \pm 27 \mathrm{f}$ & $2859 \pm 10 \mathrm{~b}$ & $1349 \pm 90 \mathrm{~b}$ & $529 \pm 13 \mathrm{c}$ \\
Pinkcot & $5609 \pm 22 \mathrm{~g}$ & $3929 \pm 54 \mathrm{~g}$ & $2680 \pm 36 \mathrm{~d}$ & $1161 \pm 37 \mathrm{e}$ \\
Veecot & $10303,8 \pm 96 \mathrm{~g}$ & $2359,9 \pm 52 \mathrm{c}$ & $1434,3 \pm 23 \mathrm{c}$ & $165,3 \pm 8 \mathrm{a}$ \\
Harcot & $7425,3 \pm 35 \mathrm{~b}$ & $3167,4 \pm 84 \mathrm{e}$ & $2427 \pm 32 \mathrm{e}$ & $183,9 \pm 2 \mathrm{a}$ \\
Harogem & $8074,4 \pm 78 \mathrm{~d}$ & $3398,9 \pm 108 \mathrm{f}$ & $2535,6 \pm 65 \mathrm{f}$ & $1048,7 \pm 45 \mathrm{~d}$ \\
\hline
\end{tabular}


23. táblázat: 7 kajszifajta cukor komponenseinek alakulása $(\mathrm{mg} / 100 \mathrm{~g})$ 80\%-os érettségben 2013ban.

\begin{tabular}{ccccc}
\hline Év & \multicolumn{4}{c}{$\mathbf{2 0 1 3}$} \\
\hline Fajta & szacharóz & glükóz & fruktóz & D-szorbitol \\
\hline Gönci magyar kajszi & $17220 \pm 107 \mathrm{~g}$ & $1750 \pm 95 \mathrm{f}$ & $560,1 \pm 9 \mathrm{c}$ & $111,2 \pm 7 \mathrm{a}$ \\
Sylvercot & $13450 \pm 51 \mathrm{e}$ & $948 \pm 35 \mathrm{a}$ & $401,5 \pm 4 \mathrm{~b}$ & $514 \pm 13 \mathrm{c}$ \\
Goldrich & $10460 \pm 83 \mathrm{c}$ & $1580 \pm 32 \mathrm{e}$ & $881,3 \pm 3 \mathrm{f}$ & $809 \pm 24 \mathrm{~d}$ \\
Pinkcot & $11171 \pm 40 \mathrm{~d}$ & $1078 \pm 47 \mathrm{~b}$ & $420 \pm 6 \mathrm{~b}$ & $370 \pm 9 \mathrm{~b}$ \\
Veecot & $7911,4 \pm 41 \mathrm{a}$ & $1342,8 \pm 36 \mathrm{c}$ & $311,2 \pm 10 \mathrm{a}$ & $542,6 \pm 14 \mathrm{c}$ \\
Harcot & $14951,9 \pm 47 \mathrm{f}$ & $1410,5 \pm 15 \mathrm{~d}$ & $656,1 \pm 24 \mathrm{~d}$ & $526,7 \pm 6 \mathrm{c}$ \\
Harogem & $10260 \pm 110 \mathrm{~b}$ & $2035,7 \pm 47 \mathrm{~g}$ & $696,9 \pm 45 \mathrm{e}$ & $1256,5 \pm 76 \mathrm{e}$ \\
\hline
\end{tabular}

A vizsgált fajtákban a cukorösszetevők közül a glükóz volt a második legnagyobb mennyiségben, ezt követte a fruktóz és a D-szorbitol. Míg a 2011-es évben a glükóz mennyisége a 'Pinkcot' fajtában volt a legnagyobb, addig a 2013-as évben a 'Harogem' fajtában. Mind a két évben a legalacsonyabb glükóz tartalmat a 'Sylvercot' fajtánál mértük.

\subsubsection{Savtartalom és összetevői}

\subsubsection{Titrálható savtartalom}

A gyümölcsök ízének megítélésében a cukortartalom mellett fontos szerepet játszik a savtartalom. Vizsgálataink során két évjáratban 2011 és 2013 vizsgáltuk a kajszifajták gyümölcsének titrálható savtartalmát. Az eredményeink alapján elmondható, hogy mind a két évben az érés elörehaladtával csökkent a savtartalom mértéke a gyümölcsökben, illetve a gyümölcs napos oldalán alacsonyabb értékeket mértünk, mint a gyümölcs árnyékos oldalán. Az eredményeket a 32. és 33. ábrákban közöljük. 2011-ben a gyümölcsök összes savtartalma 70\%os érettségben átlagosan, a gyümölcs napos oldalán: 0,5-2,6\%, az árnyékos oldalán: 0,6-3\%, volt, míg 80\%-os érettségben a napos oldalán: 0,4-2,1\%, az árnyékos oldalon: 04-2,5\% volt. 90\%-os érettségben pedig a gyümölcs napos oldalán: 0,3-2\%, az árnyékos oldalán: 0,3-2,4\% között alakult az összes savtartalom mértéke (32. ábra). Míg 2013-ban ezek az értékek 70\%-os érettségben a gyümölcs napos oldalán: 0,4-2\%, az árnyékos oldalán 0,5-2,4\%; 80\%-os érettségben a napos oldalon: 0,4-1,7\%, az árnyékos oldalon: 0,5-1,8\% voltak. 90\%-os érettségben pedig az összes savtartalom értéke a gyümölcs napos oldalán: 0,4-1,7\%, az árnyékos oldalán $0,5-1,8 \%$ voltak (33. ábra). Mind a két évben, mind a három érettségi stádiumban az 
'Orange Red' fajta gyümölcseinél mértük a legalacsonyabb savtartalmat, míg a legmagasabb értékeket 2011-ben a 'Goldrich’ és a 'Sylvercot' fajtáknál, 2013-ban pedig a 'Goldrich' fajtánál.

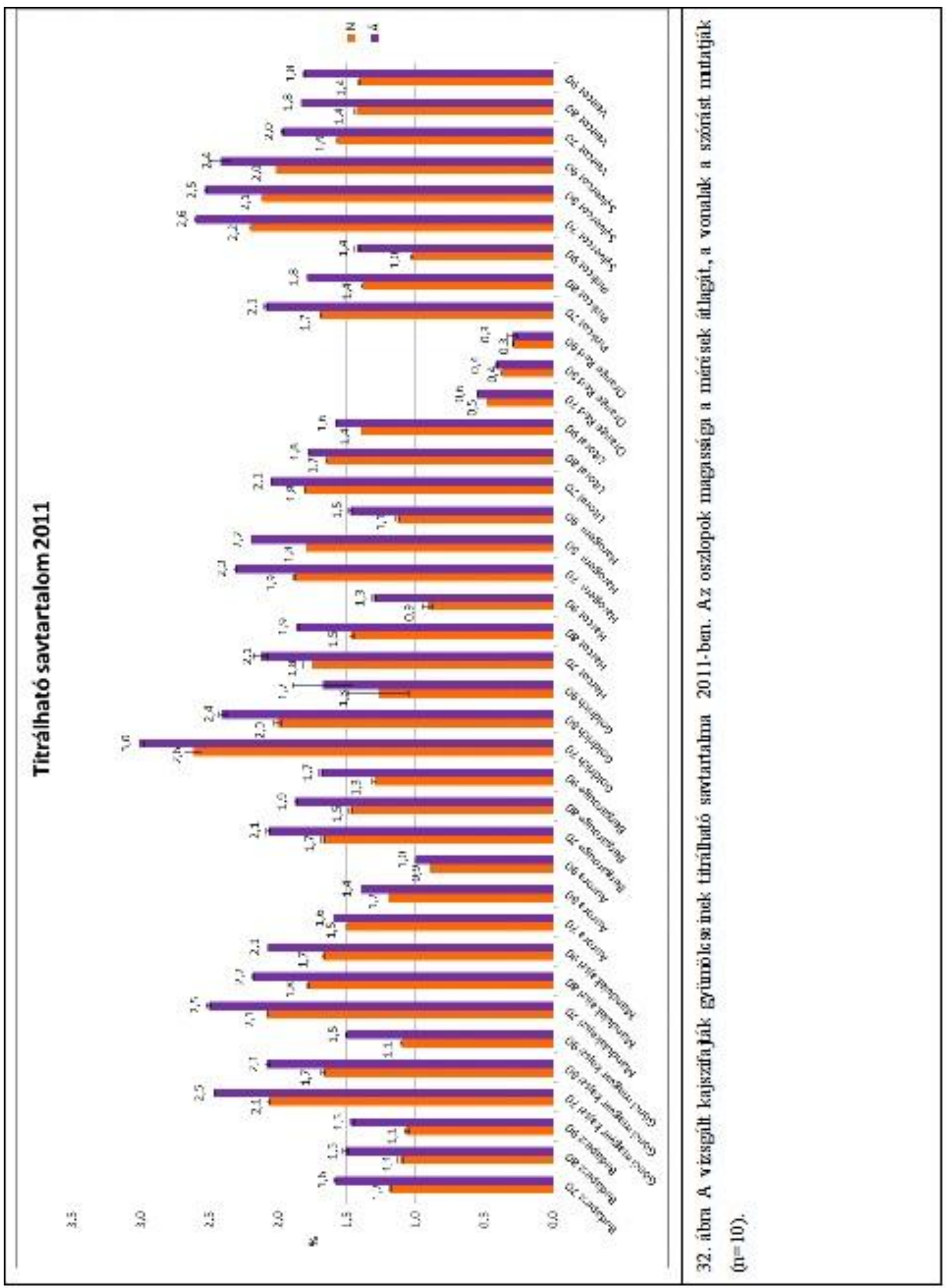




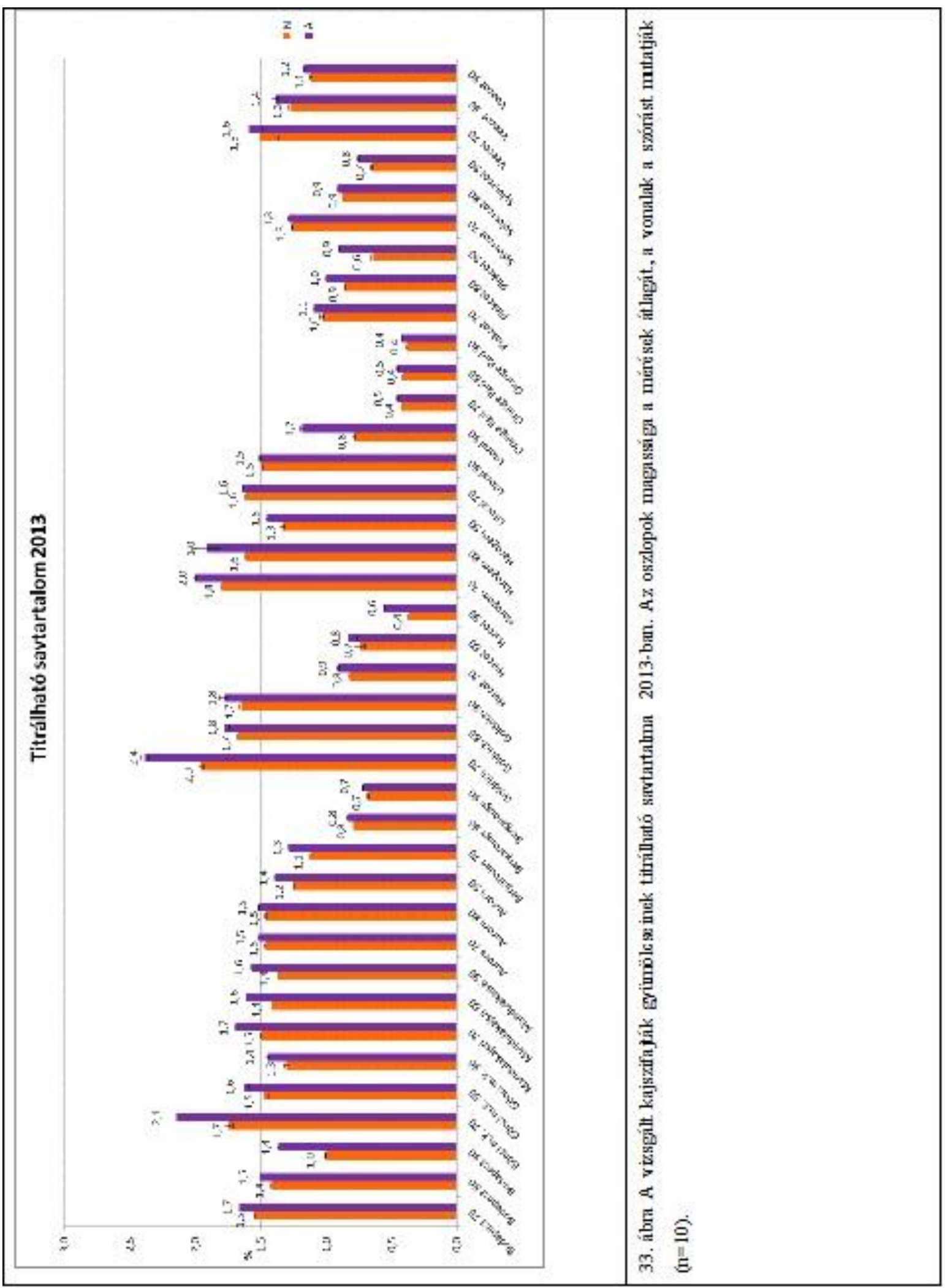




\subsubsection{Savösszetevök}

HPLC műszerrel elvégeztük a savösszetevők (almasav, citromsav, borostyánkősav) vizsgálatát is hét különböző kajszifajtánál ('Gönci magyar kajszi', 'Goldrich', 'Sylvercot', 'Pinkcot', 'Harcot', 'Harogem', 'Veecot') 80\%-os érettségi stádiumban. A szerves savak kromatogramjáról minta a M.3.9. ábrán látható. A kéttényezős MANOVA (Wilk-féle lambda) alapján állíthatjuk, hogy a vizsgált két évben szignifikáns fajtahatást és évjárathatást tudtunk kimutatni (10. modell, M.2.20. táblázat). Továbbá elmondható, hogy a savösszetevőkre szignifikánsan hat a fajta és az év is. Az interakció is szignifikánsnak bizonyult, ezért a fajtahatást évenként, az évjárathatást pedig fajtánként elemeztük. A Tukey-/Games-Howell-féle post hoc teszt alapján mind a két évben a savösszetevők alakulása tekintetében szignifikáns különbséget tudtunk kimutatni. Vizsgálati eredményeink alapján elmondható, hogy a kajszifajták legnagyobb mennyiségben almasavat, második legnagyobb mennyiségben citromsavat, legkisebb mennyiségben pedig borostyánkősavat tartalmaztak. A 2011-es évben a 'Harcot' fajtánál mértünk kiemelkedő almasav mennyiséget (24. táblázat), míg a 2013-as évben a 'Pinkcot' fajtánál (25. táblázat).

24. táblázat: 7 kajszifajta sav komponenseinek (almasav, citromsav, borostyánkősav) alakulása (mg/100g) 80\%-os érettségben 2011-ben

\begin{tabular}{cccc}
\hline Év & \multicolumn{3}{c}{$\mathbf{2 0 1 1}$} \\
\hline Fajta & almasav & citromsav & borostyánkösav \\
\hline Gönci magyar kajszi & $1378 \pm 16 \mathrm{~d}$ & $580 \pm 18 \mathrm{c}$ & $192 \pm 15 \mathrm{~d}$ \\
Sylvercot & $1295 \pm 66 \mathrm{~b}$ & $628 \pm 11 \mathrm{~d}$ & $136 \pm 1 \mathrm{a}$ \\
Goldrich & $1593 \pm 40 \mathrm{f}$ & $567 \pm 8 \mathrm{~b}$ & $152 \pm 13 \mathrm{~b}$ \\
Pinkcot & $920 \pm 15 \mathrm{a}$ & $573 \pm 18 \mathrm{bc}$ & $179 \pm 24 \mathrm{c}$ \\
Veecot & $1551,7 \pm 34 \mathrm{e}$ & $518,6 \pm 6 \mathrm{a}$ & $281 \pm 4 \mathrm{f}$ \\
Harcot & $1671,9 \pm 85 \mathrm{~g}$ & $656,9 \pm 14 \mathrm{e}$ & $195,9 \pm 11 \mathrm{~d}$ \\
Harogem & $1352,5 \pm 45 \mathrm{c}$ & $628,9 \pm 29 \mathrm{~d}$ & $244,3 \pm 9 \mathrm{e}$ \\
\hline
\end{tabular}


25. táblázat: 7 kajszifajta sav komponenseinek (almasav, citromsav, borostyánkősav) alakulása (mg/100g) 80\%-os érettségben 2013-ban

\begin{tabular}{cccc}
\hline Év & \multicolumn{3}{c}{$\mathbf{2 0 1 3}$} \\
\hline Fajta & almasav & citromsav & borostyánkősav \\
\hline Gönci magyar kajszi & $1473 \pm 10 \mathrm{~d}$ & $193 \pm 4 \mathrm{a}$ & $51 \pm 0,6 \mathrm{ab}$ \\
Sylvercot & $1284 \pm 23 \mathrm{~b}$ & $508 \pm 13 \mathrm{c}$ & $44 \pm 5 \mathrm{a}$ \\
Goldrich & $1562 \pm 6 \mathrm{e}$ & $270 \pm 4 \mathrm{~b}$ & $98 \pm 20 \mathrm{~d}$ \\
Pinkcot & $1798 \pm 51 \mathrm{~g}$ & $1146 \pm 38 \mathrm{e}$ & $60 \pm 2 \mathrm{a}-\mathrm{c}$ \\
Veecot & $1078,5 \pm 25 \mathrm{a}$ & $876,1 \pm 35 \mathrm{~d}$ & $55,6 \pm 8 \mathrm{a}-\mathrm{c}$ \\
Harcot & $1329 \pm 15 \mathrm{c}$ & $1327,2 \pm 72 \mathrm{f}$ & $63,5 \pm 7 \mathrm{bc}$ \\
Harogem & $1712 \pm 63 \mathrm{f}$ & $1334 \pm 75 \mathrm{f}$ & $71,4 \pm 3 \mathrm{c}$ \\
\hline
\end{tabular}

A citromsav mennyiségét tekintve a 2011-es évben a 'Harcot' fajtánál, míg a 2013-as évben a 'Harogem' fajtánál mértük a legnagyobb értékeket. A borostyánkősav mennyisége a 'Sylvercot' fajtánál volt a legkisebb mind a két évben.

\subsubsection{Kajszifajták vízoldható szárazanyag-és összes savtartalmának összefüggései}

A gyümölcsök vízoldható-szárazanyag- és összes savtartalmának aránya a gyümölcsök harmonikus ízét biztosítja. A vizsgálatba vont kajszifajták cukor-sav arányát a gyümölcsök refrakcióértékéböl és titrálható savtartalmából számítottuk ki 2011 és 2013-ban (26. táblázat). A legnagyobb cukor-sav aránya mind a két évben, mind a három érettségi stádiumban az 'Orange Red' fajtának volt, amely fajta esetében az alacsony vagy közepes refrakcióértékhez szintén alacsony savtartalom párosult. A legkisebb pedig 70\%-os érettségben a 'Goldrich' fajtának, 80\%-os érettségben 2011-ben a 'Sylvercot' fajtának, 2013-ban az 'Aurora' fajtának, míg 90\%-os érettségben 2011-ben a 'Mandulakajszi' fajtának, 2013-ban az 'Aurora' fajtának, volt. A 'Gönci magyar kajszi’ magasabb cukortartalmához, magasabb savtartalom párosult mind a két évben, ez adja a kiváló ízét. Vizsgálati eredményeink alapján, cukor-sav arányához hasonló értékekkel rendelkezett a 'Harogem' fajta. 
26. táblázat: A vizsgált 13 kajszifajta cukor-sav aránya

\begin{tabular}{ccccccc}
\hline Fajta & \multicolumn{2}{c}{$\mathbf{7 0}$ \%-os érettség } & $\mathbf{8 0} \%-o s$ érettség & \multicolumn{2}{c}{$\mathbf{9 0} \%$-os érettség } \\
\hline & $\mathbf{2 0 1 1}$ & $\mathbf{2 0 1 3}$ & $\mathbf{2 0 1 1}$ & $\mathbf{2 0 1 3}$ & $\mathbf{2 0 1 1}$ & $\mathbf{2 0 1 3}$ \\
\hline Budapest & 9,2 & 8,3 & 13,4 & 10,1 & 15,01 & 14,3 \\
Gönci magyar kajszi & 5,1 & 6,2 & 7,6 & 10,4 & 13,1 & 13,6 \\
Mandulakajszi & 6,1 & 7,6 & 8,02 & 9,6 & 9,8 & 12,03 \\
Aurora & 8,1 & 7,2 & 10,2 & 7,7 & 14,4 & 10,04 \\
Bergarouge & 7,6 & 12,4 & 9,7 & 20,4 & 12,4 & 25,5 \\
Goldrich & 4,6 & 7 & 6,4 & 10,2 & 10,6 & 11,8 \\
Harcot & 7 & 17,4 & 8,9 & 20,7 & 15,4 & 40,7 \\
Harogem & 6,1 & 6,8 & 7,1 & 8,1 & 12,1 & 12,2 \\
Litoral & 7,2 & 9,4 & 9,9 & 11,5 & 12,4 & 20,4 \\
Orange Red & 22,8 & 25,8 & 33,3 & 29,6 & 49 & 35,2 \\
Pinkcot & 6,6 & 11,9 & 9,04 & 15,3 & 13,4 & 20,1 \\
Sylvercot & 5,2 & 10,1 & 5,7 & 16,2 & 6,6 & 24,1 \\
Veecot & 6,8 & 9,7 & 9,3 & 13,7 & 10,4 & 17,7 \\
\hline
\end{tabular}

\subsection{4. Összefüggés-vizsgálat}

A kajszifajták nagy különbségeket mutatnak arra vonatkozóan, hogy minőségi paramétereik hogyan változnak az érés során. Vizsgálataink során két évben (2011, 2013) kerestünk összefüggést négy új külföldi fajta ('Goldrich', 'Pinkcot', 'Sylvercot', 'Veecot') húskeménységének $\left(\mathrm{kg} / \mathrm{cm}^{2}\right)$ és vízoldható szárazanyagtartalmának $\left(B r i x^{\circ}\right)$ változása között az érés során (12. modell, 34. ábra). Kontrollként a 'Gönci magyar kajszi' fajtát használtuk. A kisebb húskeménységi értékekhez, magasabb refrakció értékek, míg nagyobb húskeménységi értékekhez kisebb refrakció értékek párosultak minden fajta esetében. A 'Gönci magyar kajszi' és a 'Goldrich' gyümölcsiben a húskeménység és a vízoldható szárazanyagtartalom változásának összefüggését mind a két évben negatív telítődési modellel tudtuk leírni, míg a 'Pinkcot' fajta esetében logisztikus modellt használtunk. A 'Sylvercot' és a 'Veecot' fajta esetében a 2011-es évben a logisztikus, míg 2013-ban a negatív telítődési modell használata volt megfelelő. A 'Gönci magyar kajszi' fajta esetében a 2011-es évben ugyanahhoz a refrakció értékhez magasabb húskeménységi értékeket mértünk, mint a 2013-as évben. Ugyanez a tendencia volt megfigyelhető a külföldi fajták esetében is, tehát elmondható, hogy a 2011-es évben keményebbek voltak a kajszifajták gyümölcsei, mint a 2013-as évben. 

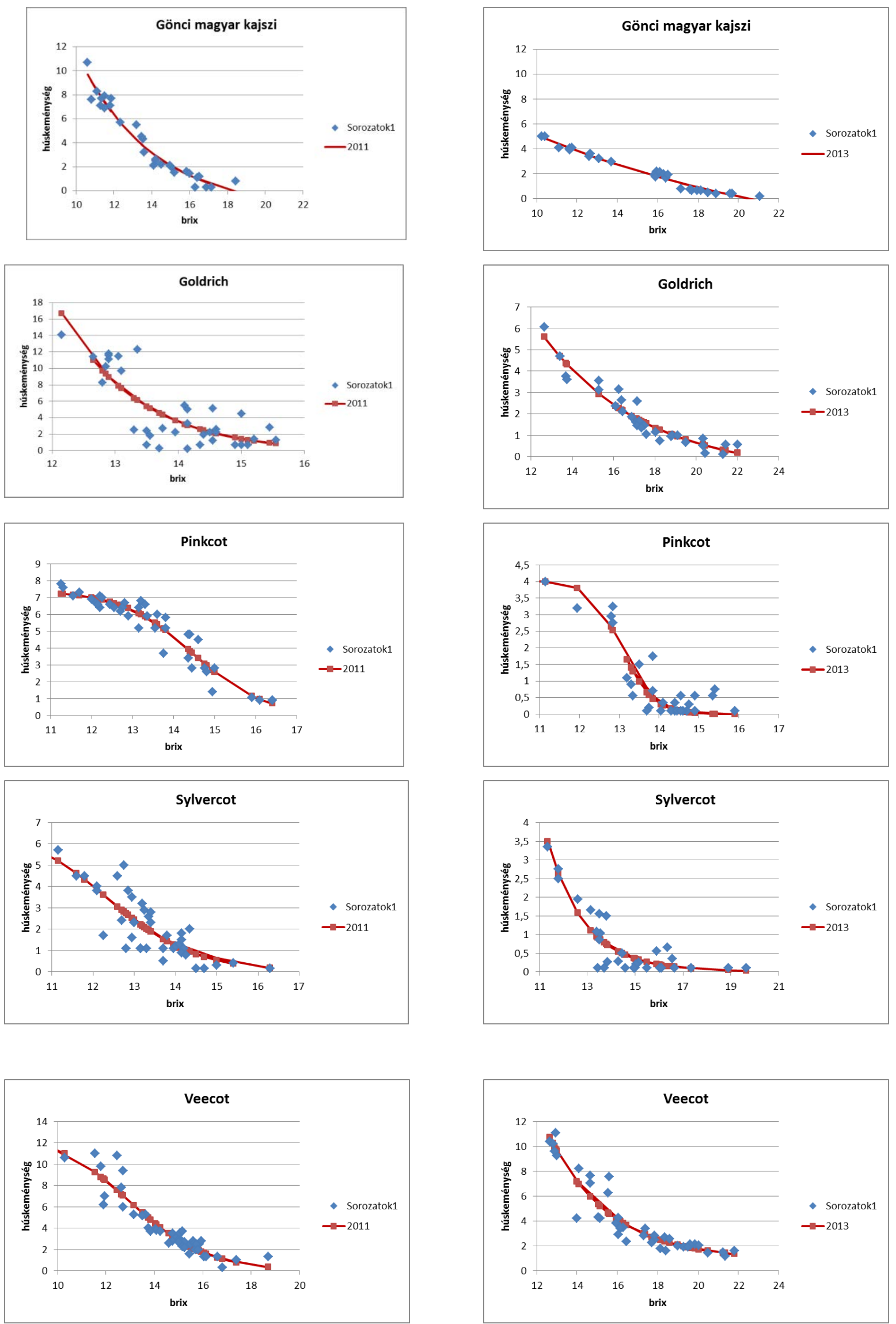

34. ábra: Kajszifajták húskeménységének és vízoldható szárazanyagtartalmának változása az érés során a 2011-es és 2013-as évben. Kék pont: megfigyelt értékek; piros vonal: modell 
A modellekhez tartozó paramétereket és azok statisztikai értékelését a M.2.21. és a M.2.22. táblázatokban közöltük.

\subsection{Kajszifajták biológiailag aktív vegyületei}

Az antioxidáns hatású vegyületek, mint például a karotinoidok és a polifenolok elengedhetetlen részei a kiegyensúlyozott étrendnek. Vizsgálataink során két évben (2011, 2013), 80\%-os érettségi állapotban vizsgáltuk négy kajszifajta ('Gönci magyar kajszi', 'Sylvercot', 'Veecot', 'Pinkcot') ß-karotin és polifenol tartalmát.

\subsubsection{Kajszifajták polifenol-tartalmának értékelése}

A kéttényezős ANOVA alapján állíthatjuk, hogy ebben a két évben, 80\%-os érettségi állapotban szignifikáns évjárathatást és fajtahatást tudtunk kimutatni, emellett az interakció is szignifikánsnak bizonyult (11. modell, M.2.23. táblázat). A szignifikáns interakció miatt a fajtahatást évenként, az évjárathatást pedig fajtánként elemeztük. A Tukey/Games Howell-féle post hoc teszt alapján mindkét évben a fajták polifenol-tartalma alakulásának tekintetében szignifikáns különbségeket tudtunk kimutatni (35. ábra). Kiemelkedő polifenol-tartalmat mind a két évben a 'Gönci magyar kajszi’ fajtánál mértünk (2011-ben 522 mg/l; 2013-ban 1267,9 mg/l). Legkisebb polifenol tartalma 2011-ben a 'Sylvercot' fajtának (242,9 mg/l); 2013-ban a 'Veecot' fajtának (370 mg/l) volt. 2013-ban a vizsgált kajszifajták polifenol tartalma magasabb volt, mint 2011-ben, ez alól kivételt képez a 'Pinkcot' fajta, amelynek 2011-ben magasabb volt a polifenol tartalma, mint 2013-ban. A 'Gönci magyar kajszi' fajtában 2013-ban több mint kétszer annyi polifenol volt, mint 2011-ben.

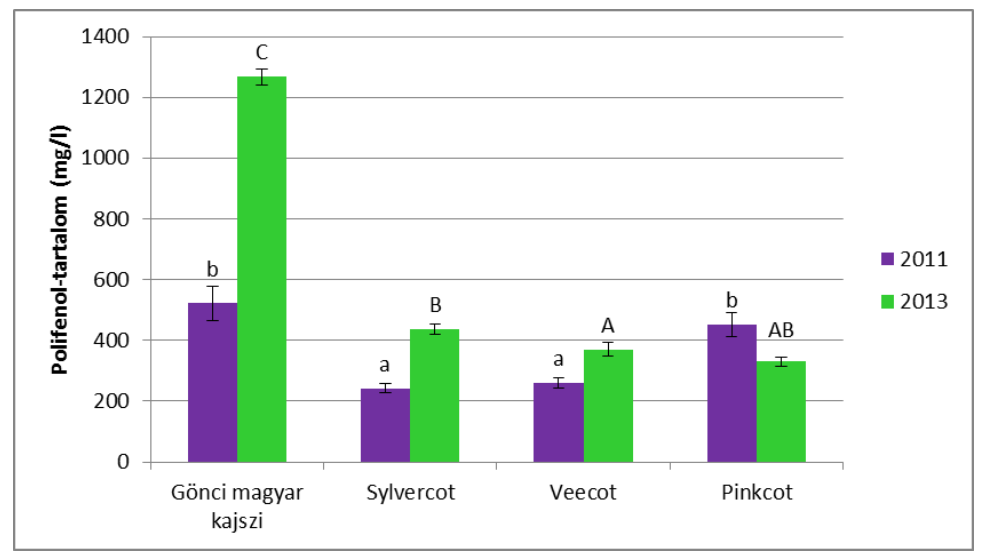

35. ábra: A vizsgált kajszifajták gyümölcseinek polifenol-tartalma 80\%-os érettségben 2011 és 2013-ban. Az oszlopok magassága a mérések átlagát, a vonalak a szórást mutatják ( $\mathrm{n}=3)$. A különböző betük szignifikánsan különböző csoportokat jelölnek a Games-Howell- /Tukey-féle post hoc teszt szerint p $<0,05$ szinten (fekete kisbetü: 2011-es év; fekete nagybetü: 2013-as év). 
Az évek között szignifikáns különbséget találtunk a 'Gönci magyar kajszi', a 'Sylvercot' és a 'Veecot' fajták esetében (M.2.24. táblázat).

\subsubsection{Kajszifajták ß-karotin-tartalmának értékelése}

A kéttényezős ANOVA alapján állíthatjuk, hogy ebben a két évben, 80\%-os érettségben csak az évjárathatás volt szignifikáns, a fajtahatás és az interakció nem bizonyult szignifikánsnak (11. modell, M.2.25. táblázat).

A Tukey-/Games Howell-féle post hoc teszt alapján mindkét évben a fajták ß-karotin tartalma alakulásának tekintetében szignifikáns különbségeket tudtunk kimutatni (36. ábra). 2013-ban minden fajta esetében magasabb ß-karotin tartalmat mértünk, mint 2011-ben. Kiemelkedő ß-karotin tartalma mind a két évben a 'Veecot' (2011-ben 1,76 mg/100 g; 2013-ban 2,87 mg/100 g) és a 'Gönci magyar kajszi' (2011-ben 1,6 mg/100 g; 2013-ban 2,8 mg/100 g) fajtáknak volt. Legalacsonyabb értéket 2011-ben a 'Sylvercot' fajtánál (1,07 mg/100g), 2013-ban a 'Pinkcot' fajtánál $(2,02 \mathrm{mg} / 100 \mathrm{~g})$ mértünk.

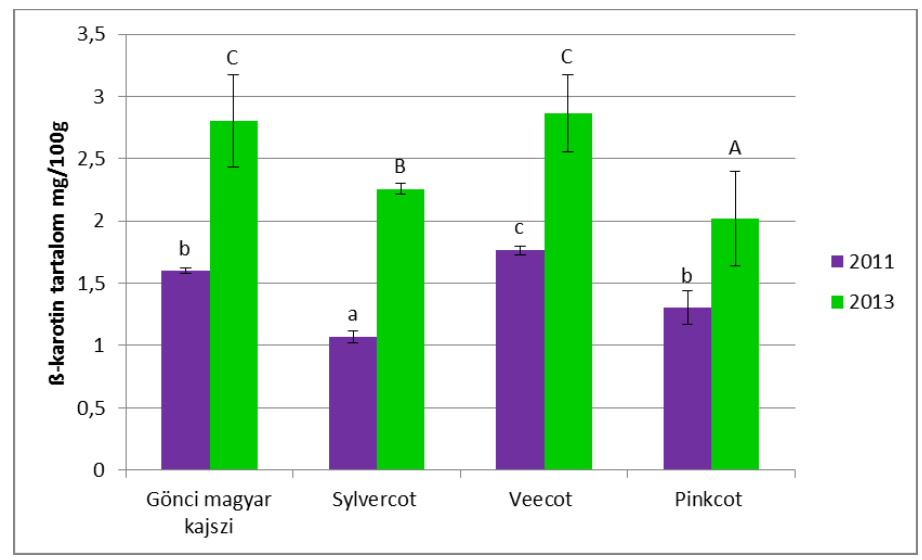

36. ábra: A vizsgált kajszifajták gyümölcseinek ß-karotin tartalma (mg/100g) 2011 és 2013-ban. Az oszlopok magassága a mérések átlagát, a vonalak a szórást mutatják $(\mathrm{n}=4)$. A különböző betűk szignifikánsan különböző csoportokat jelölnek a Games-Howell- /Tukey-féle post hoc teszt szerint p $<0,05$ szinten (fekete kisbetü: 2011-es év; fekete nagybetű: 2013-as év).

Az évek között, 80\%-os érettségben szignifikáns különbséget találtunk a 'Gönci magyar kajszi', a 'Sylvercot' és a 'Veecot' fajták esetében (M.2.26. táblázat). 


\section{AZ EREDMÉNYEK MEGVITATÁSA, KÖVETKEZTETÉSEK}

\subsection{Virágrügyek és virágok fagytürése}

A kajszi gazdaságos termeszthetőségét a faj rossz ökológiai alkalmazkodóképessége jelentősen befolyásolja (Badenes et al., 1998). Hazánkban az alacsony hőmérséklet károsító hatása jelenti a legnagyobb problémát (Szalay, 2003), amit vizsgálati eredményeink is igazoltak. Hazánk területén ősszel, télen és tavasszal is jelentkezhet fagykár, de a legnagyobb problémát a tavaszi fagyok okozzák (Szalay, 2003; Surányi és Molnár, 2011). Az általunk vizsgált három évből kettőnél mi is tapasztaltunk természetes fagykárt, ebből a 2012-es fagykár mértéke olyan súlyos volt, hogy júliusban nem tudtunk Soroksáron kajszit szüretelni. A fagytürés alakulását a növény genetikailag öröklött tulajdonságai határozzák meg, ezért a fajták között jelentős különbségek vannak (Pénzes és Szalay, 2003). Kutatómunkánk során mi is jelentős különbségeket találtunk a vizsgálatba vont kajszifajták fagytürése között. A fagyállóságot a környezeti tényezők nagymértékben befolyásolják, ezért a fajták fagyállóságának alakulása eltérő lehet a különböző termőhelyeken és évjáratokban (Pénzes és Szalay, 2003). Az általunk vizsgált három év nagyon hasonló volt egymáshoz, ezért szignifikáns évjárathatást nem tudtunk kimutatni.

A kajszi áttelelő szervei közül télen a virágrügyek károsodnak a legnagyobb mértékben, ezért ennek a szervnek a vizsgálatára helyeztük a hangsúlyt a többi kutatóhoz hasonlóan (Quamme, 1974., Hewett, 1968, 1976; Proebsting és Mills, 1978; Bartolini et al., 2006c; Szalay et al., 2010, Yao, 2011; Salazar-Gutiérrez, 2014). A mesterséges fagyasztásos vizsgálat a legpontosabb módszer az áttelelő szervek fagyállóságának meghatározásához (Proebsting és Mills, 1978; Westwood., 1993; Layne és Gadsby, 1995; Pedryc et al., 1999; Miranda et al., 2005; Szalay et al., 2010), ezért mi is ezt a módszert alkalmaztuk. A fagytürő képesség jellemzésére leggyakrabban az $\mathrm{LT}_{50}$ értékeket használják (Proebsting és Sakai, 1979; Gu, 1999; Lindén és Palonen, 2000; Lindén, 2002; Meng et al., 2007; Szalay et al., 2010; Ferguson et al., 2011; Salazar-Gutiérrez et al., 2014). A fagyasztásos kísérletek eredményei alapján mi is minden vizsgálati időpontban meghatároztuk a vizsgált fajták virágrügyeinek $\mathrm{LT}_{50}$ értéket, így összehasonlíthatóvá váltak a különböző fajták és évjáratok. Az $\mathrm{LT}_{50}$ értékeket többféle statisztikai módszerrel próbálták meghatározni (Burr et al., 1993; Zhu és Liu, 1987; Lindén et al., 1996), mi ezek közül a lineáris regressziót alkalmaztuk a szigmoid görbe 20 és 80\%-os fagykár közé eső szakaszára, mely jól becsülhető egy lineáris összefüggéssel. Hewett (1976); Lindén et al. (1996); Gu (1999) a fagytürési görbe ezen szakaszát szintén lineárisnak ábrázolta. 
A vizsgált fajták virágrügyeinek fagytürőképesség-változási dinamikája hasonló képet mutat. A tél első felében folyamatosan nőtt a fagyállóságuk a külső hőmérséklet csökkenésével párhuzamosan, majd a tél második felében a fagytürésük fokozatosan csökkent. Hatch és Walker, (1969); Hewett, (1976); Szalay et al., (2010) a kajszi virágrügyek vizsgálatakor hasonló tendenciát mutattak ki. A kajszihoz közeli rokon fajok és más gyümölcsfajok virágrügyeinek fagyállóságát vizsgálva szintén ilyen tendenciákat mutattak ki (Proebsting, 1970; Proebsting és Mills, 1978; Fergusson et al., 2011; Salazar-Gutiérrez et al., 2014).

A mérsékelt égövi lombhullató fák áttelelő szerveinek fagyállósága több ütemben alakul ki (Tromp, 2005). A vizsgált kajszifajták közül két standard fajtánál kimutattuk, hogy a virágrügyeik edződésének folyamata két jól elkülöníthető szakaszra osztható. Az első szakasz jóval az őszi lombhullás előtt elkezdődött. Ennek során a virágrügyek fagyállósága kezdetben gyorsan, majd egyre lassuló ütemben növekedett, és elért egy fajtára jellemző értéket. Az edződés második szakasza abban az időszakban volt, amikor a külső napi minimum hőmérsékletek tartósan fagypont alá csökkentek. Kísérletekkel már igazolták, hogy az alma háncsszövetek edződésének második szakasza csak akkor játszódott le, ha a hőmérséklet $4,5^{\circ} \mathrm{C}$ alá csökkent (Howel és Weiser 1970). Ugyancsak kísérletileg igazolt, hogy a 'Redhaven' őszibarackfajta virágrügyeinek megfelelő megedződéséhez fagypont alatti hőmérsékletek szükségesek, enélkül nem alakult ki az edződés második szakasza (Szalay et al., 2010). Kísérleti eredményeink arra utalnak, hogy a kajszifajták virágrügyei is csak akkor érik el a genotípusra jellemző legjobb értékeket, ha az edződési folyamat lejátszódásához szükséges feltételek megvannak. Ez azt jelenti, hogy összel fokozatosan csökken a környezet hőmérséklete, majd az edződési folyamat első szakaszának lejátszódása után tartósan fagypont alá csökken a hőmérséklet, aminek hatására az edződés második szakasza is le tud játszódni. Vizsgálati eredményeink alapján a három évjárat között csak kisebb különbségeket tapasztaltunk, szignifikáns évjárathatás nem volt kimutatható. Mind a három évjáratra jellemző, hogy a virágrügyek nem tudtak teljes mértékben megedzödni az enyhébb tél miatt.

A virágrügyek decemberben és januárban voltak a legfagytürőbbek. Ekkor a standard fajtáknak a 2011 -es évjáratban $-20,8{ }^{\circ} \mathrm{C}$ és $-23,3{ }^{\circ} \mathrm{C}$, a 2012 -es évjáratban $-20,5{ }^{\circ} \mathrm{C}$ és $-23{ }^{\circ} \mathrm{C}$, a 2013-as évjáratban pedig -20,2 és -22,9 közötti fagytürési középértéket mértünk. A legkisebb értékeket mind a három évben a 'Ceglédi bíborkajszi' fajtánál, a legnagyobb értékeket pedig a 'Rózsakajszi C. 1406' fajtánál mértük. A ‘Gönci magyar kajszi’ fajta esetében az LT $_{50}$ értékek a következőképpen alakultak: 2011-ben -21,5 ${ }^{\circ} \mathrm{C}$, 2012-ben $-21,4{ }^{\circ} \mathrm{C}, 2013$-ban pedig $-21,7{ }^{\circ} \mathrm{C}$. Szalay (2001) két évben (1997/1998, 1998/1999) vizsgálta a ‘Ceglédi bíborkajszi' és a 'Gönci magyar kajszi’ virágrügyeinek fagytürési középértékeinek változását Szigetcsépen. Vizsgálati 
eredményei alapján decemberben voltak a legfagytüröbbek a fajták. Eredményeinek összevetése a saját eredményeinkkel az 27. táblázatban található, mely alapján elmondható, hogy hasonlóan alakult a két fajta fagytürési középértékei. A különbségek egyfelöl az évjárathatás, másfelől a különböző termőhely eredményezhette.

27. táblázat: A ‘Ceglédi bíborkajszi’ és a ‘Gönci magyar kajszi’ fagytürési középértékeinek alakulása a vizsgálati évek leghidegebb hónapjában két termőhelyen (Szigetcsép és Soroksár)

\begin{tabular}{cccccc}
\hline Fajta & $\mathbf{1 9 9 7 / 1 9 9 8}$ (Szalay, & $\mathbf{1 9 9 8 / 1 9 9 9 .}$ (Szalay, & $\mathbf{2 0 1 0 / 2 0 1 1}$ & $\mathbf{2 0 1 1 / 2 0 1 2}$ & $\mathbf{2 0 1 2 / 2 0 1 3 .}$ \\
& $\mathbf{2 0 0 1})$ & $\mathbf{2 0 0 1 )}$ & év & év & év \\
\hline CB & $-22,5$ & -20 & $-20,8$ & $-20,5$ & $-20,2$ \\
GÖ & $-22,5$ & -22 & $-21,5$ & $-21,4$ & $-21,7$ \\
\hline
\end{tabular}

CB: Ceglédi bíborkajszi; GÖ: Gönci magyar kajszi

A három mindegyik évjáratban vizsgált külföldi fajta ('Goldrich', 'Pinkcot', 'Sylvercot') virágrügyei esetében a fagytürési középértékek a leghidegebb időpontban a következőképpen alakultak: 2011-es évjáratban $-18,3{ }^{\circ} \mathrm{C}$ és $-18,8^{\circ} \mathrm{C}$, a 2012 -es évjáratban $-19,5{ }^{\circ} \mathrm{C}$ és $-21{ }^{\circ} \mathrm{C}$, a 2013-as évjáratban pedig $-18,9{ }^{\circ} \mathrm{C}$ és $-20,5{ }^{\circ} \mathrm{C}$ között. A szakirodalmakban nem találtunk adatokat ezeknek a fajtáknak az $\mathrm{LT}_{50}$ értékeik alakulásáról a tél folyamán.

Az alany a nemes télállóságát befolyásolhatja (Nitranski, 1977; Vaszily, 2012). Vizsgálataink során a 'Sylvercot' fajta fagytürésének alakulását a 2010/2011-es évjáratban három különböző alanyon (myrobalan, Missuri, C29) vizsgáltuk. Mind a három alanyon kis különbséget mértünk a fajta $\mathrm{LT}_{50}$ értékei alakulása tekintetében, ez alól kivételt képez a 2011. február 21-ei időpont, mert ekkor a myrobalan alanyon lévő 'Sylvercot' fajta $1,7{ }^{\circ} \mathrm{C}$-kal alacsonyabb hőmérsékletet is elviselt, mint a C29-es alanyon lévő. Majdnem minden vizsgálati időpontban a myrobalan alanyon volt a legfagytüröbb a fajta, C29-es alanyon a legfagyérzékenyebb, de összességében az alany pozitív hatását fagytürésének javítására nem tudtuk igazolni.

Vizsgálataink során további 9 külföldi kajszifajta fagytürésének alakulását is megvizsgáltuk a tél folyamán. A 2010/2011-es évjáratban a 'Sylred', a 'Pisana' és a 'Laycot' fajtákat, a 2011/2012-es évben az 'Orange Red', 'Sweet Red' és 'Veecot' fajtákat, míg a 2012/2013-as évben az 'Aurora', 'Bergarouge' és a 'Harlayne' fajtákat vizsgáltuk. Jelentős különbségeket tudtunk kimutatni a vizsgált fajták között. A vizsgálati eredményeink alapján a külföldi kajszifajták közül fagytürő genotípust, csak a 2012/2013-as évben tudtunk kiemelni, a 
legtöbb vizsgált fajta közepesen fagytürőnek vagy fagyérzékenynek bizonyult. Kiemelkedő fagytüröképessége a vizsgált külföldi kajszifajták közül csak a 'Harlayne' fajtának volt, 2012 decemberétől a 'Rózsakajszi C. 1406' fajtánál is fagytürőbbnek bizonyult. Szalay (2001) az 1998/1999-es évjáratban Szigetcsépen végzett fagytürési vizsgálatai alapján rangsorolt 20 kajszifajtát fagytürésük átlaga alapján, s a 'Harlayne' fajtát ő is jó fagytürésűnek találta. Vizsgálta továbbá az általunk vizsgált fajták közül az 'Orange Red', valamint a 'Veecot' fajtákat is. Kutatási eredményei alapján a 'Veecot' fajtát jó fagytürésűnek, míg az 'Orange Red' fajtát fagyérzékenynek találta. A mi vizsgálati eredményeink alapján e két fajta közepes fagytürésü volt. A különbségek abból adódhatnak, hogy különböző termőhelyen, s más évjáratban történtek a vizsgálatok. A 2010/2011-es évben mind a hat vizsgált új külföldi fajta a 'Ceglédi bíborkajszinál' fagyérzékenyebb volt. A mindegyik évjáratban vizsgált kajszifajták ('Goldrich', 'Sylvercot', 'Pinkcot') közül a 'Pinkcot' fajta mind a három évben fagyérzékeny volt, a 'Goldrich' fajta, csak a 2010/2011-es évben, míg a 'Sylvercot' fajta a 2010/2011 és a 2012/2013as évben volt fagyérzékeny, a többi évben közepesen fagytürök voltak. Az 'Aurora', 'Goldrich', 'Sylvercot', 'Sylred', 'Pinkcot', 'Laycot', 'Bergarouge', 'Pisana', valamint a 'Sweet Red' kajszifajták fagytürési középértékeinek alakulásáról a szakirodalmakban nem találtunk adatokat. Vizsgálati eredményeink alapján fagyérzékenynek az 'Aurora', a 'Laycot', a 'Sweet Red', a 'Pinkcot', a 'Sylvercot', a 'Pisana', valamint a 'Sylred' fajta bizonyult, a 'Goldrich' és a 'Bergarouge' fagytürése közepes volt.

A virágzási időszakban a generatív szervek fagyállósága függ a fenológiai fázistól, minél elörehaladottabb az adott fenofázis, annál fagyérzékenyebb a fajta (Pénzes és Szalay, 2003). Vizsgálati eredményeink alapján mind a három virágzási időszakban hasonló tendenciát tudtunk kimutatni. A 28. táblázatban a 'Ceglédi bíborkajszi' és a 'Gönci magyar kajszi' fajta LT $_{50}$ értékeit tüntettük fel három évben $(2011,2012,2013)$ a virágzás különböző fenofázisában összevetve a szakirodalomban talált adatokkal. 
28. táblázat: A ‘Ceglédi bíborkajszi’ és a ‘Gönci magyar kajszi’ fagytürési középértékeinek alakulása a virágzás különböző fenofázisában két termőhelyen (Szigetcsép és Soroksár)

\begin{tabular}{ccccccccc}
\hline Fenofázis & $\mathbf{1 9 9 6}$ (Pénzes és Szalay, 2003) & \multicolumn{2}{c}{$\mathbf{2 0 1 1}$} & \multicolumn{2}{c}{$\mathbf{2 0 1 2}$} & \multicolumn{2}{c}{$\mathbf{2 0 1 3}$} \\
& \multicolumn{2}{c}{ Szigetcsép } & & \multicolumn{2}{c}{ Soroksár } & \multicolumn{2}{c}{ Soroksár } & \multicolumn{2}{c}{ Soroksár } \\
\cline { 2 - 10 } & CB & GÖ & CB & GÖ & CB & GÖ & CB & GÖ \\
\hline ZCS & - & - & $-5,2$ & -6 & $-5,2$ & $-5,8$ & $-4,4$ & $-5,1$ \\
PB & -7 & -10 & $-5,1$ & $-5,8$ & $-5,1$ & $-5,6$ & $-4,1$ & $-4,8$ \\
HB & $-5,5$ & -7 & $-4,5$ & $-5,5$ & $-3,8$ & $-4,5$ & $-2,8$ & $-3,8$ \\
VK & -5 & -7 & -4 & -5 & $-3,5$ & $-4,2$ & $-2,6$ & $-3,7$ \\
FV & -4 & -5 & $-3,8$ & $-4,6$ & -3 & $-3,8$ & $-2,5$ & $-3,5$ \\
VV & -3 & -4 & $-3,5$ & $-4,2$ & -2 & $-2,6$ & $-1,6$ & $-2,4$ \\
\hline
\end{tabular}

CB: Ceglédi bíborkajszi; GÖ: Gönci magyar kajszi; ZCS: zárt csészebimbó, PB: pattanó csészebimbó, HB: hólyagbimbó; VK: virágzás kezdet; FV: fővirágzás; VV: virágzás vége

A táblázatban közölt adatok alapján a 'Gönci magyar kajszi' fajta LT $_{50}$ értéke 1996-ban pattanó csészebimbós állapotban $-10{ }^{\circ} \mathrm{C}$, fővirágzás idején már csak $-5^{\circ} \mathrm{C}$ volt. Az általunk mért adatok esetében is megfigyelhető volt ez a tendencia pl. 2011-ben a 'Gönci magyar kajszi' fajta $\mathrm{LT}_{50}$ értéke pattanó csészebimbós állapotban $-5,8^{\circ} \mathrm{C}$, addig fóvirágzás idején $-4,6^{\circ} \mathrm{C}$ volt. Mind a két fajta esetében mind a három virágzási időszakban a szakirodalmi adatokhoz képest alacsonyabb fagytürési középértékeket mértünk, ami valószínűleg a különböző termőhelynek és az évjárathatásnak tudható be. Külföldi országokban is hasonló tendenciát mutattak ki a kutatók (Kostina, 1977; Proebsting és Mills, 1978; Guerriero, 1982; Hewett, 1976; Guerriero et al., 2006). A szakirodalmi adatok alapján továbbá jól látható, hogy a két fajta között jelentős különbség van, a vizsgálati eredményeink alapján mi is szignifikáns fajtahatást tudtunk kimutatni, emellett szignifikáns volt az évjárathatás is.

\subsection{Kajszifajták mikrosporogenézise}

A mikrosporogenézis ütemét a környezeti tényezők, elsősorban a hőmérséklet nagymértékben befolyásolják (Szalay, 2008), ebből adódnak az évjáratok közötti jelentős különbségek. Ezt alátámasztják a 3 évjáratban 9 fajtával végzett kísérleti munkánk eredményei is. A fajták sorrendje azonban mind a három évben azonos volt, ami azt igazolja, hogy a mikrosporogenézis is, mint minden fenológiai folyamat alapvetően genetikailag szabályozott. Így kevés számú évjárat vizsgálati eredményei alapján is nagy biztonsággal sorrendbe tudjuk állítani a vizsgált fajtákat a virágrügyeik mélynyugalmának vége és a mikrosporogenézisük üteme szempontjából. 
Új fajták termesztésbe vonása előtt termőhelyi alkalmasságukról meg kell győződnünk. Ehhez hasznos adatokat szolgáltatnak a fenológiai vizsgálatok. Egy adott termöhelyen egy új fajta eredményes termeszthetőségét a fenológiai vizsgálatok alapján jól meg tudjuk becsülni, ha ismert fagy- és télállóságú, régen termesztésben lévő kontroll fajtát használunk.

A mikrosporogenézis üteme és a virágrügyek áttelelő szerveinek fagyállósága között nincs szoros összefüggés, mivel eltérő genetikai szabályozás alatt állnak (Bassi et al., 2006). A mélynyugalom végének időpontja azonban nagymértékben befolyásolja a fajta fagy- és télállóságát, mivel az áttelelő szervek fagyállóságának csökkenése csak a kényszernyugalmi időszakban következik be (Szalay 2001, 2008).

A gazdaságos termeszthetőség északi határa közelében azok a fajták felelnek meg legjobban számunkra, amelyek áttelelő szervei, köztük elsősorban a virágrügyek, lassú ütemben fejlődnek a tél folyamán, mélynyugalmuk későn ér véget, és hosszú ideig megőrzik fagytűrő képességüket (Szalay 2001, 2008). A rövid mélynyugalmú, gyors virágrügyfejlődésű kajszifajták tőlünk délre, a mediterrán térségben termeszthetők eredményesen (Guerriero et al., 1988). A termésbiztonság szempontjából a hozzánk hasonló ökológiai körülmények között nemesített, hosszú mélynyugalmú, fagytürő kajszifajták igen ígéretesek Magyarországon a fajtaválaszték bővítésére (Szalay, 2001, 2008). Romániában a kajszi nemesítési program egyik célkitüzése volt a mérsékelt égövi területek számára alkalmas, jó fagy- és télállóságú, későn virágzó fajták előállítása (Cociu 1982, 1991; Cociu és Hough, 1985). Az általunk vizsgált román fajták ebből a nemesítési programból származnak. Kanadában szintén fontos cél volt a kajszinemesítés során a fagy- és télállóság fokozása (Layne 1978, 1979, 1981; Layne és Gadsby 1995). A kanadai nemesítési program eredményeként létrejött fajták közül hármat vizsgáltunk munkánk során.

A három éves vizsgálati időszakban 5 db Észak-Amerikában és 3 db Romániában nemesített kajszifajta fenológiai folyamatait vizsgáltunk a Magyarországon árutermelő ültetvényekben legelterjedtebb, közepes fagy- és télállóságú 'Gönci magyar kajszi' fajtát használva kontrollként. Vizsgálati eredményeink alapján sorrendbe állítottuk a vizsgált fajtákat mikrosporogenézisük üteme szempontjából. Mind a három évben azonos sorrend alakult ki. Ez a sorrend egyben a termésbiztonságot jelző sorrendnek is tekinthető. A sorrend elején szereplő 'Pinkcot' fajta virágrügyeinek mélynyugalma már január 10 és 25 közötti időszakban véget ért, míg a sorrend végén lévő 'Harlayne’ fajtáé csak február 5 és 10 között. A vizsgált fajták között 3 volt, amelyek virágrügyfejlődése gyorsabbnak bizonyult a kontrollétól, sorrendben a 'Pinkcot', az 'Orange Red' és a 'Harcot' fajták. Ezeknek a fajtáknak a termesztése a 'Gönci magyar kajszi’-tól nagyobb kockázattal jár Magyarországon, a gyors téli virágrügyfejlődésük miatt. A 'Gönci magyar kajszi’-tól lassúbb virágrügyfejlődésűek, tehát nagyobb biztonsággal 
termeszthetők sorrendben a vizsgálataink szerint a következők: 'Litoral', 'Harogem', 'Comandor', 'Sirena' és 'Harlayne'.

\subsection{Kajszifajták áruértékét meghatározó tulajdonságok}

A gyümölcs mérete, színe, alakja, külső megjelenése a fogyasztók vásárlását döntően befolyásolja, de ezek a paraméterek nem garantálják a gyümölcsök ízét és állagát (Azodanlou és munkatársai, 2002). A gyümölcs fogyasztói megítélésében a fent említett paramétereken kívül jelentős szerepe van a cukrok és savak mennyiségi arányának, amely a gyümölcs harmonikus ízét biztosítja (Parolari et al., 1992).

A nemzetközi piacokon egyre komolyabb elvárások jelentkeznek a kajszi gyümölcsét illetően, csak kiváló minőségü, nagy gyümölcsmérettel rendelkező, jól pultontarható kajszifajtákra van kereslet. Kajszi esetében nagy gyümölcsűnek Pedryc és Hermán (2011) szerint a 60 g-nál nagyobb tömegü, vagy 50 mm-nél nagyobb átmérőjü fajták tekinthetők. A friss piacon minimális követelmény a 40 mm átlagos gyümölcsátmérő. Vizsgálati eredményeink alapján négy kajszifajta, mind a két vizsgálati évben $(2011,2013)$, mind a három érettségi stádiumban (70\%, 80\%, 90\%) 60g-nál nagyobb gyümölcstömeget produkált. Ez a négy fajta a következő volt: 'Budapest', 'Goldrich', 'Pinkcot', 'Sylvercot'. A 2013-as évben a 'Bergarouge' és a 'Harcot' fajták is 60 g-nál nagyobb tömegüek voltak. A fajták és az évjáratok között szignifikáns különbséget tudtunk kimutatni más kutatókhoz hasonlóan (Asma et al., 2005; Cociu, 2006; Ruiz és Egea, 2008; Bureau et al.; 2009; Farina et al., 2010; Roussos et al., 2011). A kajszi gyümölcsök az érési folyamat során jelentős mértékben növekednek (Surányi és Molnár, 1981, Szalay, 2003; Farina et al., 2010; Németh, 2012). Vizsgálataink során három különböző érettségi állapotban $(70 \%, 80 \%, 90 \%)$ vizsgáltuk a kajszifajták gyümölcs tömegének alakulását, s a fent említett kutatókhoz hasonlóan az érés elörehaladtával növekvő tendenciát tapasztaltunk a vizsgálatba vont összes fajta esetében.

A gyümölcsök méretét nem csak a tömeg, hanem további paraméterek (magasság, szélesség és vastagság) is jellemzik. Az általunk vizsgált kajszifajtáknál mi is meghatároztuk ezeket a paramétereket, de a szélességi értékeket hasonlítjuk össze, mivel ez a gyümölcsök legnagyobb átmérője, amely során a posztharveszt műveletek során az osztályozás történik. Eredményeink alapján elmondható, hogy azok a fajták, amelyek nagy gyümölcsmérettel rendelkeztek, a 'Goldrich' fajta kivételével, majdnem minden érettségi stádiumban elérték az 50 mm-es átmérőt. A 40 mm-es minimum átmérőt eredményeink alapján minden fajta elérte, ez alól kivételt képez az 'Aurora' fajta 2011-es átlagos szélessége két érettségi stádiumban (70\%, 80\%). 
A fajták és az évjáratok között ennél a paraméternél is szignifikáns különbséget tudtunk kimutatni. Az érés előrehaladtával ezek a paraméterek is növekedtek. Hasonló tendenciáról számolt be Farina et al. (2010) és Németh (2012).

A húskeménység a kajszigyümölcs alapvető minőségi tulajdonsága (Bassi et al., 1992), meghatározza a gyümölcs áruvá készítését, szállítását és pultontarthatóságát. A kajszi gyümölcs húsállománya az érés előrehaladtával egyre puhább lesz (Szalay és Balla, 2003; Kovács et al., 2008; Farina et al., 2010; Hitka, 2011). Vizsgálataink során mi is ezt a tendenciát tudtuk kimutatni. A gyümölcsök húskeménysége a napos és árnyékos oldalon nem egyforma, vizsgálati eredményeink alapján a gyümölcs napos oldalán puhábbak voltak a gyümölcsök mind a két vizsgálati évben, az általunk vizsgált összes fajtánál. Szalay és Balla (2003) különböző kajszifajtákat vizsgált 90\%-os érettségben, s a gyümölcs árnyékos oldalán az általa vizsgált fajtáknál magasabb húskeménységi értékeket mért. Kiemelkedő húskeménységi értékeket 2011ben 70\%-os érettségben a 'Goldrich' és a 'Veecot' fajtánál mértünk, 2013-ban az 'Orange Red' és a 'Veecot' fajtáknál. Vizsgálati eredményeinket a 29. táblázatban vetjük össze a szakirodalmi adatokkal.

29. táblázat Az általunk vizsgált kajszifajták húskeménységi értékei 90\%-os érettségben, összehasonlítva a szakirodalmakban talált adatokkal

\begin{tabular}{|c|c|c|c|c|c|c|}
\hline \multirow[t]{3}{*}{ Fajta } & \multicolumn{2}{|c|}{$\begin{array}{l}\text { Húskeménység } \\
\left(\mathbf{k p} / \mathrm{cm}^{2}\right)\end{array}$} & \multicolumn{2}{|c|}{$\begin{array}{c}\text { Húskeménység }\left(\mathrm{kg} / \mathrm{cm}^{2}\right) \\
2011\end{array}$} & \multicolumn{2}{|c|}{$\begin{array}{c}\text { Húskeménység }\left(\mathrm{kg} / \mathrm{cm}^{2}\right) \\
2013\end{array}$} \\
\hline & \multicolumn{6}{|c|}{ Szalay és Balla, 2003} \\
\hline & $\mathbf{N}$ & Á & $\mathbf{N}$ & Á & $\mathbf{N}$ & Á \\
\hline ORR & 2,18 & 2,67 & 2,92 & 3,36 & 2,58 & 3,16 \\
\hline MK & 1,39 & 1,93 & 0,89 & 1,9 & 0,97 & 1,39 \\
\hline
\end{tabular}

ORR: Orange Red; MK: Mandulakajszi; N: a gyümölcs napos oldala; Á: a gyümölcs árnyékos oldala

Az 'Orange Red' fajtáról továbbá elmondható, hogy minden érettségi állapotban jó húskeménységi értékeket mértünk. Ruiz és Egea (2008) Spanyolországban szedési érettségben az 'Orange Red' fajtánál $1,97 \mathrm{~kg} / \mathrm{cm}^{2}$ húskeménységi értékről számolt be, amely az általunk mért értékeknél alacsonyabb volt. Valentini et al. (2006) Olaszországban az 'Orange Red' fajtánál, friss fogyasztási érettségben $3,46 \mathrm{~kg} / \mathrm{cm}^{2}$ húskeménységet mért. 2011-ben 90\%-os érettségben a gyümölcs árnyékos oldalán hasonló értéket kaptunk ennél a fajtánál. Costa (2012) vizsgálati eredményei alapján az 'Orange Red' és a 'Bergarouge' kajszifajtákat keményhúsúnak találta. Eredményeink alapján ezt a két fajtát mi is jó húskeménységünek találtuk. Franciaországban a 
'Goldrich’ fajta gyümölcseinél jó hússzilárdságot mértek Bureau et al. (2006). Kutatómunkánk során 3 különböző érettségi állapotban, a gyümölcs napos és árnyékos oldalán is mértük a kajszifajták húskeménységét két vizsgálati évben. Ilyen részletes adatokkal nem találkoztunk a szakirodalmi forrásokban. Vizsgálati eredményeink alapján a húskeménységet, mint fizikai paramétert vizsgálva szignifikáns fajta és évjárathatást tudtunk kimutatni. Farina et al. (2010) két kajszifajta ('Pellecchiella', 'Vitillo') húskeménységét vizsgálta három különböző érettségi állapotban. Vizsgálati eredményei alapján a két fajta húskeménysége között szignifikáns különbséget nem tudott kimutatni.

2011-ben négy magyar és öt külföldi kajszifajta húskeménységének változását többféle módszerrel is vizsgáltuk az érés során. A kézi penetrométeres vizsgálat minden esetben kisebb hússzilárdságot mutatott ki, mint TA44 henger alakú próbatesttel mért müszeres vizsgálat, esetenként a különbség a 15 \%-ot is elérte. A különbség abból adódhatott, hogy az eltérő méretü mérőfejeknél különböző a hús közvetlen roncsolásából és mérőtest oldalához való tapadásból adódó ellenállás aránya. Harmadik módszerként tủ alakú mérötesttel is vizsgáltuk a gyümölcsök húskeménységét. Mind a három mérési módszerrel hasonló tendenciákat mutattunk ki. A 37. ábrán mutatjuk be a kézi penetrométerrel, valamint az állományelemző müszer két eltérő próbatestével mért eredményeinek összehasonlítását (7. modell). A Pearson-féle korrelációs együttható alapján szignifikáns kapcsolatot mutattunk ki a kézi penetrométerrel mért húskeménységi értékek és a TA44-es henger alakú mérőfejjel müszeresen mért értékek $\left(\mathrm{R}^{2}=0,993 ; \mathrm{p}<0,001\right)$; valamint a kézi penetrométerrel és a TA9-es tű alakú mérőfejjel müszeresen mért húskeménységi értékek $\left(\mathrm{R}^{2}=0,925 ; \mathrm{p}<0,001\right)$ között. Ugyancsak szignifikáns kapcsolatot mutattunk ki a két müszeres mérési módszer között $\left(\mathrm{R}^{2}=0,946 ; \mathrm{p}<0,001\right)$ is. Ez alapján elmondható, hogy mind a három vizsgálati módszer alkalmas a gyümölcsök húskeménységének meghatározására, és a gyümölcshús állományváltozásának érés alatti nyomonkövetésére. Statisztikailag erősebb korrelációt tudtunk kimutatni a kézi penetrométer és a TA44-es henger alakú műszeres mérőfej eredményei között, mint a kézi penetrométeres mérési módszer és a TA9-es tü alakú müszeres mérési módszer között, de a kapcsolat szorosságában tapasztalt különbség nem volt számottevő. Ezért elvégeztük 90\%-os érettségben a kézi penetrométerrel és a tủ alakú mérőtesttel mért húskeménységi értékek összehasonlító elemzését. A Pearson-féle korrelációs együttható alapján ebben az esetben nem tudtunk szignifikáns kapcsolatot kimutatni a kétféle mérési módszer között $\left(\mathrm{R}^{2}=0,65 ; \mathrm{p}>0,5\right)$. Ez alapján arra következtettünk, hogy 90\%-os érettségben, amikor a gyümölcsök már puhábbak, a tü alakú mérőfej kisebb roncsolása miatt precízebb eredményeket kaptunk, mint a kézi penetrométeres mérés esetében. Ezt a feltevésünket erősítette meg az a tény is, hogy a 70- és 80\%-os érettségben, szilárdabb húsállomány mellett mindhárom mérési módszer eredménye 
statisztikailag igazolhatóan hasonló volt. A húsállomány puhulásával, a 90\%-os érettségi állapotban a tủ alakú mérőtesttel mért értékek valamennyi vizsgált fajta esetében magasabbak voltak a Magness Taylor-féle kézi penetrométerrel mért értékeknél, ezért kijelenthetjük, hogy az érés előrehaladtával a TA9-es tü alakú mérőfej kutatási célokra alkalmasabb, pontosabb mérést tesz lehetővé.

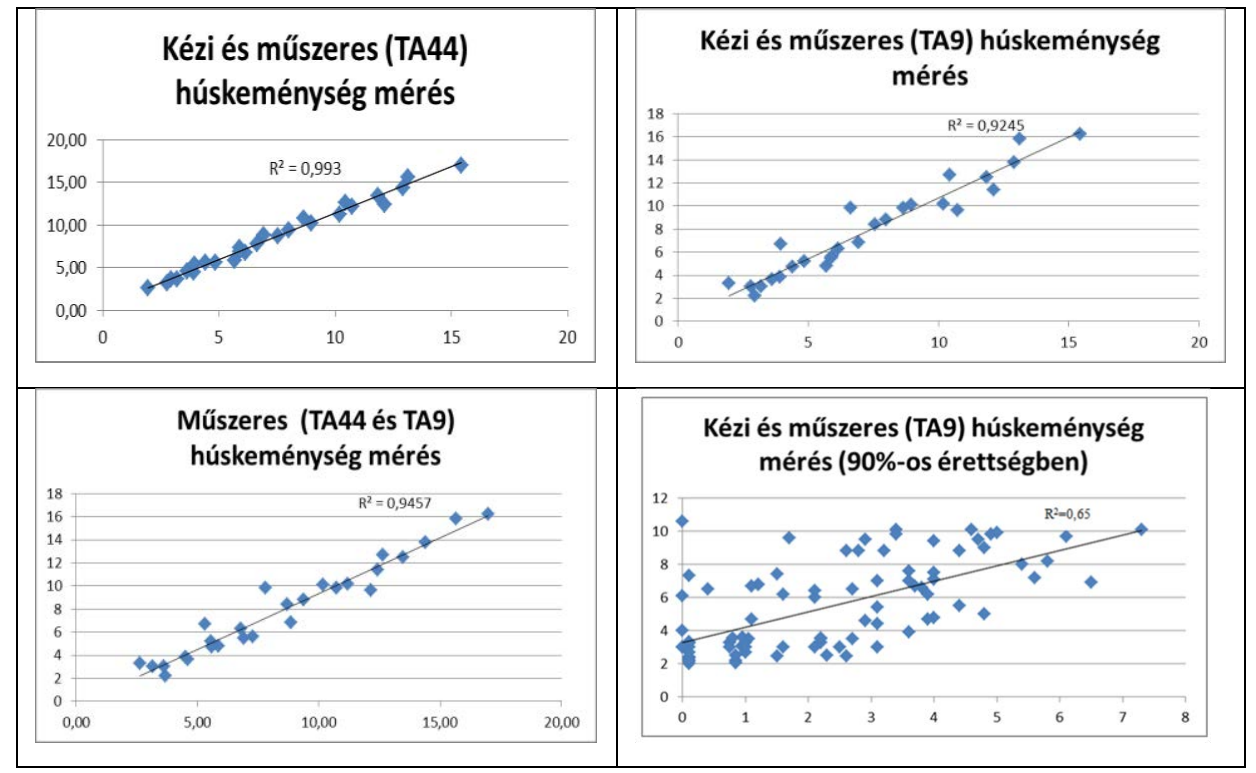

37. ábra A kézi penetrométer és a müszeres húskeménység (TA44 és TA9) mérés közötti korreláció

A vizsgálatban szereplő magyar fajták közül három magyar fajta ('Budapest', 'Ceglédi arany', és a 'Gönci magyar kajszi') gyümölcsei voltak a legpuhábbak, emellett ezek húskeménysége gyors ütemben csökkent az érés során. A 'Mandulakajszi' kezdeti húskeménysége nagyobb volt, de a ennek a fajtának a gyümölcsei is gyorsan puhultak az érés során. Szalay és Balla (2003) kézi penetrométerrel vizsgálva hasonló húskeménységi értékeket mértek a magyar fajtáknál. Kovács et al. (2008) a 'Gönci magyar kajszi' gyümölcseinek húskeménységét vizsgálták tủ alakú mérőfejjel, 4 különböző érettségi állapotban. Az érés során a gyümölcshús gyors puhulását állapították meg. Vizsgálataink során a legkeményebb húsú fajták a külföldi fajták közül kerültek ki. A 'Hargrand', 'Harogem' és a 'Laycot' gyümölcseinek húskeménysége kiemelkedően magas volt 70\%-os érettségben $\left(15-16 \mathrm{~kg} / \mathrm{cm}^{2}\right)$, és az érés során kisebb ütemben puhultak, mint a magyar fajták gyümölcsei. Ezek a fajtákat befött készítésre javasoljuk. A vizsgált külföldi fajták közül a 'Harlayne' és a 'Veecot' gyümölcsei a magyar fajtákéhoz hasonlóan puha húsúak voltak. A 'Budapest', 'Ceglédi arany', 'Gönci magyar kajszi' és a 'Harlayne' fajták puhább húskeménységüek, ezért alkalmasak lehetnek lekvárnak, pürének.

2013-as évben 9 kajszifajta esetében vizsgáltuk három különböző érettségi stádiumban húskeménységük, valamint állományparamétereik (adhéziós erő, kohéziós erő és rágósság) 
változását az érés során Brookfield típusú állománymérő műszer, tű alakú próbatestének használatával. Vizsgálati eredményeink alapján a húskeménység alakulása tekintetében a penetrométeres mérésekhez hasonló tendenciát tudtunk kimutatni ebben a vizsgálati évben. Az adhéziós erő és a rágási energia szükséglet az érés előrehaladtával csökkent, a kohéziós erő esetében nem tudtunk egyértelmű növekvő vagy csökkenő tendenciát kimutatni, bizonyos fajták esetében nem változott a mértéke vizsgálati eredményeink alapján. Mind a három érettségi stádiumban szignifikáns fajtahatást tudtunk kimutatni. Ficzek et al. (2011) állománymérő müszerrel különböző almahibridek húskeménységét és állományparamétereinek alakulását vizsgálták optimális szüreti időpontban és 4 hónap tárolást követően. A húskeménység, az adhézió és a rágási energiaszükséglet mértékében csökkenő tendenciát mutattak ki, a kohéziós erő mértéke a legtöbb fajta esetében minimálisan csökkent a tárolás során. Kajszifajták esetében nem találtunk a szakirodalmakban részletes müszeres vizsgálatokat állományparamétereik változásáról az érés előrehaladtával, ezért a kapott eredményeinket nem tudtuk összehasonlítani.

A kajszi fogyasztói megítélését jelentős mértékben befolyásolja a gyümölcsök cukortartalma. Vizsgálataink során két évben $(2011,2013)$ vizsgáltuk különböző kajszifajták vízoldható szárazanyagtartalmát három különböző érettségi stádiumban. Az érés során a gyümölcshús szárazanyagtartalma nő (Szalay és Balla, 2003). A vizsgálati eredményeink alapján az általunk vizsgált kajszifajtáknál növekvő tendenciát tudtunk kimutatni az érés elörehaladtával. Minden fajta esetében elmondható, hogy a gyümölcs napos oldalán magasabb volt a vízoldható szárazanyagtartalom, mint az árnyékos oldalon, továbbá szignifikáns volt a fajta és az évjárathatás is. A kajsziról a szakirodalomban közzétett cukortartalom átlagos értéke 1,57 és 11,85 \% között van (Ghorpade és Hanna, 1995). Az általunk vizsgált kajszifajtáknál ennél jóval magasabb értékeket mértünk. A gyümölcsök 70 \%-os érettségében a 2011-es évben a 'Gönci magyar kajszi', a 2013-as évben az 'Aurora' és az 'Orange Red' fajtáknak volt a legalacsonyabb a vízoldható szárazanyagtartalma, ezeknek a fajtáknak az értékei körülbelül 11 és $12 \%$ körül mozogtak. Farina et al. (2010) az általa vizsgált két fajtának a vízoldható szárazanyagtartalmát 11 és 16\% között határozta meg. Asma et al. (2007) által vizsgált török kajszifajták vízoldható szárazanyagtartalma 12,7 és 26,6\% között volt. Az általunk vizsgált legmagasabb vízoldható szárazanyagtartalmat a 2013-as évben 90\%-os érettségben a 'Goldrich' fajta napos oldalán mértük (22,05\%). Roussos et al. (2011) Görögországban az általa vizsgált három kajszifajta ('Bebecou', 'Nafsika', 'Niove') esetében szedési érettségben 10,6 és 14,4\% \% -os brix értékről számolt be. Ruiz és Egea (2008) Spanyolországban termesztett kajszifajták vízoldható szárazanyagtartalmát szedési érettségben 10,6-14,3 \% között adták meg, a legmagasabb értékkel az 'Orange Red' fajta rendelkezett. A vizsgálati eredményeink alapján az 'Orange Red' fajtánál 90\%-os érettségben mi is hasonló értékeket mértünk. Az általunk vizsgált magyar kajszik 
vízoldható szárazanyagtartalma 90\%-os érettségben általában magasabb volt, mint a külföldi fajtáké. Vizsgálati eredményeinket összehasonlítva a külföldi országokban termesztett kajszifajták vizsgálati eredményeivel elmondható, hogy hazánkban termesztett kajszifajták gyümölcsében magasabb a cukortartalom, mint a külföldön termesztett kajszik esetében, kivételt képez ez alól a török eredetü kajszik, mert a török fajták brix ${ }^{\circ}$-a meghaladta a hazánkban termesztett kajszifajtákét.

A kajszi cukortartalmát döntő mértékben a szacharóz adja, a glükóz és a fruktóz aránya jóval kisebb (Szalay és Balla, 2003). Vizsgálati eredményeink alapján az általunk vizsgált kajszifajtákban is a szacharóz mennyisége volt a legjelentősebb. A Souci et al. (2008) által közölt tápanyagtáblázat alapján a szacharóz tartalom a kajszi gyümölcseiben 3600-5980 mg/100g, míg a glükóz mennyisége 950 és 2880 mg /100 g. Vizsgálataink során az általunk vizsgált 7 kajszifajta esetében magasabb szaharóz tartalom értékeket mértünk. 80\%-os érettségben a szacharóz tartalom 2011-ben 5609-10303 mg/100g között alakult, míg 2013-ban 7911,4-17220 mg/100g volt. A glükóz mennyisége 2011-ben 1730-3929 mg/100g, míg 2013-ban 948-2035,7 mg/100g, ami a Souci et al. (2008) által közölt adataival közel megegyezőek voltak. Bureau et al. (2009) vizsgálati eredményei alapján az általuk vizsgált kajszifajtákban a következő értékeket adták meg: szacharóz: 500-10700 mg/100g, glükóz: 700-4900 mg/100g; fruktóz: 3001900 mg/100g. Roussos et al. (2011) a kajszifajták szacharóz tartalmát 3680-5220 mg/100g, a glükóz tartalmat 710-1170 mg/100g, a fruktóz mennyiségét 370-710 mg/100g, a szorbitol mennyiségét pedig 330-1110 mg/100g-ban adta meg. Németh et al. (2011a) magyar kajszifajták esetében a szacharóztartalmat 7370-11390 mg/100g adta meg. Štampar et al. (1999) Az általunk vizsgált kajszifajták magas szacharóz tartalma miatt cukorbetegségben szenvedők csak körültekintően fogyasszák.

A gyümölcsök ízének a megítélésében a cukortartalom mellett fontos szerepet játszik a savtartalom, amely az érés elörehaladtával csökken (Szalay és Balla, 2003). Vizsgálati eredményeink alapján mi is hasonló tendenciát tudtunk kimutatni. A gyümölcsök napos oldalán alacsonyabb, míg az árnyékos oldalán magasabb savtartalmi értékeket kaptunk. A szakirodalmakban az összes savtartalom mértékét a kajsziban 1,4 \%-ban adják meg (Souci et al., 1989) 2011-ben 90 \%-os érettségben 0,3-2,2\%, míg 2013-ban 0,5-1,8\% között alakult az általunk vizsgált kajszifajták összes savtartalma. A legalacsonyabb savtartalmat mind a két évben, mind a három érettségi állapotban az 'Orange Red' fajta gyümölcseiben mértük, míg a legmagasabb savtartalmat a 'Goldrich' fajtánál. Ruiz és Egea (2008) szedési érettségben vizsgált kajszifajtákban 0,92 és 2,45\% savtartalomról számolt be. Roussos et al. (2011) szedési 
érettségben 1,43 és 2,5\%-os savtartalmat mért. Asma (2007) a török kajszifajták esetében 0,25 és $1,1 \%$-os savtartalomról számolt be.

A kajszi gyümölcsökben többféle szerves sav található. Ezek összetételéről a szakirodalomban ellentmondásos adatok találhatók. A legnagyobb mennyiségben almasavat és citromsavat tartalmaz a kajszi gyümölcsök húsa, kisebb mennyiségben borostyánkősavat (Souci et al., 2008). Egyes kutatási eredmények azt mutatják, hogy bizonyos fajták esetében az almasav dominál, más fajtáknál a citromsav. Vizsgálati eredményeink alapján az általunk vizsgált kajszifajták esetében az almasav mennyisége volt minden fajta esetében mind a két évben nagyobb. A vizsgált fajtákban 80\%-os érettségben az almasav mennyisége 2011-ben 920-1671 mg/100g között, 2013-ban 1078,5-1798 mg/100g között volt, a citromsav mennyisége 2011-ben 518,6-659,6 mg/100g, míg 2013-ban 193-1334 mg/100g közötti értékeket mutatott. Akin et al. (2008) az általuk vizsgált kajszifajtáknál 973-3930mg/100g almasav mennyiségről és 431,89999,7 mg/100g citromsav mennyiségről számolt be. Vizsgálati eredményei alapján a 'Bursa' és az 'Igdir' nevü kajszifajtáknál a citromsav mennyisége magasabb volt, mint az almasav mennyisége. A többi fajta gyümölcseiben az almasav mennyisége volt nagyobb. Štampar et al. (1999) a 'Laycot', a 'Pellecchiella', és a 'Tomcot' fajták esetében a citromsav mennyisége magasabb volt, mint az almasav. Más fajtáknál az almasav mennyisége dominált. Az ide vonatkozó kutatási eredmények alapján tehát elmondható, hogy a fajtától függ, hogy a gyümölcsökben az almasav vagy a citromsav található nagyobb mennyiségben.

A vízoldható szárazanyagtartalom és a titrálható savtartalom aránya, mint mutató jól alkalmazható a gyümölcsök harmonikus ízének megadására. A gyümölcsök magasabb cukor/sav aránya magasabb minőségű beltartalomra utal (Gómez és Ledbetter, 1997; Ledbetter et al., 2006). Mratinic et al. (2011) kajszi genotípusok cukor/sav arányát határozták meg szedési érettségben, a vizsgált kajszifajták cukor/sav aránya 6,63-14,94 között alakult. Az általunk vizsgált kajszifajták cukor/sav aránya bizonyos fajták és érettségi fokok esetében meghaladta az általa mérteket. 70\%-os érettségben: 2011-ben 4,6-22,8; 2013-ban 6,2-25,8, 80\%-os érettségben 2011-ben 5,7-33,3, 2013-ban 7,7-29,6, míg 90\%-os érettségben 2011-ben 6,6-49, 2013-ban 12,235,2 volt. Ledbetter et al. (2006) által vizsgált genotípusok cukor/sav aránya 19-49,1 volt. Az 'Orange Red' fajta esetében kaptuk a legmagasbb cukor/sav arány értéket, azonban ez az érték alacsony vagy közepes refrakció és alacsony savtartalom értékekből származott. Magas cukor/sav arányt mértünk bizonyos érettségi stádiumokban a 'Harcot' és 'Bergarouge' fajták esetében, amely magas cukor és közepes savtartalom arányából kaptunk. A 'Gönci magyar kajszi’ fajta gyümölcsét magas cukor és magas sav tartalom jellemezte, 80\%-os érettségben 2011-ben 7,6, 2013-ban 10,4 volt a cukor/sav aránya a fajtának. Hegedűs (2013) az általa 
vizsgált régi magyar fajták cukor/sav arányát 8-9 között adta meg, melyböl kiegyensúlyozott cukor/sav arányra következtetett. A 'Harogem' fajtának nagyon hasonlóan alakult a 'Gönci magyar kajszi’ fajtához viszonyítva a cukor/sav aránya.

Vizsgálataink során öt kajszifajta esetében modelleztük a két vizsgálati év $(2011,2013)$ alapján a fajták húskeménysége és vízoldható szárazanyagtartalma közötti összefüggést. Ezt a változást két modellel tudtuk jellemezni: a negatív telítődési modellel, valamint a logisztikus modellel. Minden fajta esetében elmondható, hogy kisebb húskeménységi értékekhez, magasabb refrakció értékek, míg nagyobb húskeménységi értékekhez kisebb refrakció értékek párosultak. A modellekkel jól alá tudjuk támasztani azt a megállapítást, hogy az érés elörehaladtával a húskeménység csökken, míg a vízoldható szárazanyagtartalom növekszik. A szakirodalmakban nem találtunk ilyen jellegű modelleket, így eredményeinket nem tudtuk összehasonlítani.

\subsection{Kajszifajták biológiailag aktív vegyületei}

A kajszi gyümölcse gazdag forrása a polifenoloknak és a karotinoidoknak, amelyek az egészségmegőrzés szempontjából nélkülözhetetlen vegyületek. Vizsgálataink során 5 kajszifajta ß-karotin és összes polifenoltartalmát vizsgáltuk meg 80\%-os érettségi állapotban.

A 'Gönci magyar kajszi' fajtánál, valamint 2011-ben a 'Pinkcot' fajtánál magas polifenoltartalmat mértünk. Campbell és Padilla-Zakour (2013) három kajszifajta ('Hargrand', 'Harlyne', 'Harogem') összpolifenoltartalmát vizsgálták. A 'Hargrand' fajta esetében 322 mg/l, a 'Harlayne' fajta esetében 276 mg/l, míg a 'Harogem' fajtánál 206 mg/l értékeket kaptak. Az általunk vizsgált kajszifajták polifenoltartalma 2011-ben, 80\%-os érettségben 242-522 mg/l, 2013-ban 330,4-1267,9 mg/1 között volt. Akin és munkatársai (2008) az általuk vizsgált 11 kajszifajta összes polifenoltartalma 423-818 mg/l között alakult. Hegedűs et al. (2010) és Hegedüs (2013) vizsgálatai során a korai érésü fajták gyümölcseiben mérte a legkisebb, míg a 'Preventa' fajtánál a legmagasabb összes polifenoltartalmat. Eredményeiböl igazolta, hogy az összes polifenoltartalom kialakítása szempontjából a genotípus meghatározó, továbbá az évjárat is szignifikánsan befolyásolta az összes polifenoltartalmat. Vizsgálati eredményeink alapján mi is szignifikáns fajta és évjárathatást tudtunk kimutatni.

A kajszi gyümölcsében jelentős a ß-karotin tartalom, Souci et al. (2008) 0,6-6,4 mg/100g között határozták meg. Az általunk vizsgált kajszifajták ß-karotintartalma is, az általuk megadott tartományba esett. 2011-ben 80\%-os érettségben a 'Veecot' és 'Gönci magyar kajszi' fajtánál mértünk kiemelkedő ß-karotin tartalmat (1,8 és 1,6 mg/100g). 2013-ban a vizsgálatba vont 
fajtáknál magasabb ß-karotin tartalmat mértünk (kb. 0,5x nagyobbat), mint a 2011-es évben. Akin et al. (2008) 11 vizsgált kajszifajta esetében a ß-karotin tartalmat 5,74-48,69 mg/100g értékben adta meg. Dragoviz-Uzelac et al. (2007) 'Magyar kajszi' fajta ß-karotin tartalmát vizsgálták különböző érettségi stádiumban. A ß-karotin mennyisége vizsgálati eredményeik alapján 0,18-1,4 mg/100 g között volt. Sass-Kiss et al. (2005) 3,11 mg/100g ß-karotintartalmat tudtak kimutatni a 'Gönci magyar kajszi’ fajta esetében.

Kuttatómunkánk fontos célja volt annak meghatározása, hogy a vizsgált külföldi fajták beilleszhetők-e a hazai fajtaválasztékba. A vizsgálati eredményeinket a 30. táblázatban foglaltuk össze. Ezek alapján elmondható, hogy azok a fajták, amelyeknek gyors volt a mikrosporogenézisük üteme, azok hamarabb léptek ki a mélynyugalomból, s fagyérzékenynek bizonyultak. Fagytürő a hosszabb mélynyugalmú 'Harlayne' fajta volt csak. Sok fagyérzékeny vagy közepesen fagytürönek bizonyuló fajta ('Pinkcot', 'Sylvercot', 'Goldrich', 'Veecot', 'Bergarouge') esetében elmondható, hogy nagy gyümölcsmérettel rendelkeztek, közepes vagy jó húskeménységűek voltak. Védett termőhelyen érdemes a termesztésükkel foglalkozni. Az 'Aurora' fajtát nem javasoljuk termesztésre fagyérzékenysége és gyenge gyümölcsminősége miatt. 
30. táblázat Kajszifajták jellemzése faggyal szembeni ellenállóságuk, a mikrosporogenézisük üteme, valamint a gyümölcsök fizikai és kémiai tulajdonságai alapján

\begin{tabular}{|c|c|c|}
\hline Fajta & $\begin{array}{l}\text { Faggyal szembeni ellenállóság/ } \\
\text { mikrosporogenezis üteme }\end{array}$ & Gyümölcs fizikai/kémiai tulajdonságai \\
\hline Aurora & fagyérzékeny & $\begin{array}{l}\text { közepes méret, gyenge húskeménység, alacsony } \\
\text { cukor és savtartalom }\end{array}$ \\
\hline Laycot & fagyérzékeny & jó húskeménység \\
\hline Pinkcot & $\begin{array}{c}\text { fagyérzékeny/ gyors a } \\
\text { virágrügyfejlődésének üteme }\end{array}$ & $\begin{array}{c}\text { nagy gyümölcsméret, közepes húskeménység, } \\
\text { közepes cukor- és savtartalom }\end{array}$ \\
\hline Sylvercot & fagyérzékeny & $\begin{array}{l}\text { nagy gyümölcsméret, közepes húskeménység, } \\
\text { közepes cukortartalom, magas savtartalom }\end{array}$ \\
\hline Goldrich & közepesen fagytürö & $\begin{array}{c}\text { nagy gyümölcsméret, közepes húskeménység, } \\
\text { közepes vagy nagy cukortartalom, magas } \\
\text { savtartalom }\end{array}$ \\
\hline Orange Red & $\begin{array}{l}\text { közepesen fagytürö/ gyors a virágrügy } \\
\text { fejlődésének üteme }\end{array}$ & $\begin{array}{c}\text { közepes méret, jó húskeménység, közepes cukor } \\
\text { és alacsony savtartalom }\end{array}$ \\
\hline Veecot & közepesen fagytürö & $\begin{array}{c}\text { nagy méret, jó húskeménység, magas cukor- és } \\
\text { savtartalom }\end{array}$ \\
\hline $\begin{array}{l}\text { Gönci magyar } \\
\text { kajszi (kontrol) }\end{array}$ & $\begin{array}{l}\text { közepesen fagytürö/ közepesen gyors a } \\
\text { virágrügy fejlődésének üteme }\end{array}$ & $\begin{array}{l}\text { közepes vagy nagy méret, kicsi vagy közepes } \\
\text { húskeménység, magas cukor-és savtartalom }\end{array}$ \\
\hline Bergarouge & közepesen fagytürő & $\begin{array}{l}\text { nagy gyümölcsméret, közepes húskeménység, } \\
\text { magas cukortartalom, közepes savtartalom }\end{array}$ \\
\hline Harlayne & fagytürése kiváló/virágrügyfejlődése lassú & gyümölcse közepes húskeménységü \\
\hline Harcot & gyors a virágrügy fejlődésének üteme & $\begin{array}{c}\text { közepes vagy nagy méret, közepes } \\
\text { húskeménység, magas cukortartalom, közepes } \\
\text { savtartalom }\end{array}$ \\
\hline Litoral & $\begin{array}{c}\text { közepesen gyors a virágrügy fejlődésének } \\
\text { üteme }\end{array}$ & $\begin{array}{c}\text { közepes méret, kis húskeménység, magas cukor- } \\
\text { és savtartalom }\end{array}$ \\
\hline Harogem & $\begin{array}{c}\text { közepesen gyors a virágrügy fejlödésének } \\
\text { üteme }\end{array}$ & $\begin{array}{l}\text { közepes gyümölcsméret, jó húskeménység, } \\
\text { magas cukor- és savtartalom }\end{array}$ \\
\hline
\end{tabular}




\section{7. ÚJ TUDOMÁNYOS EREDMÉNYEK}

1. Mesterséges fagyasztásos eljárással, lineáris regressziós modellel határoztam meg tizenkét külföldi és három hazai kajszifajta virágrügyeinek fagytürését a nyugalmi időszakban, és hierarchikus klaszteranalízissel három érzékenységi csoportba soroltam a fajtákat.

2. Statisztikai vizsgálatokkal alátámasztottam az évjárat kajszifajták virágszerveinek fagytürését modifikáló hatását.

3. Nyolc külföldi és egy kontroll magyar kajszifajta nyugalmi állapotban való virágrügyfejlődésének vizsgálata alapján meghatároztam a mikrosporogenézis ütemét és sorrendjét. Ezek alapján igazoltam öt külföldi kajszifajta hazai ökológiai viszonyok között való termesztésének alkalmasságát.

4. Müszeres mérési módszerek összehasonlítása alapján bizonyítottam, hogy a kajszi gyümölcshúsállomány érés alatti változásának monitorozására és a fajták közötti eltérések bemutatására a tủ alakú mérőfej alkalmasabb, mint a henger alakú.

5. Eltérő szakirodalmi ismeretek közül azokat erősítettem meg, amelyek szerint a kajszigyümölcsben a savkomponensek közül az almasav a legjelentősebb.

6. Nemlineáris regressziós modellel közelítettem öt kajszifajta húskeménységének változását a vízoldható szárazanyag-tartalom függvényében, két vizsgálati évben. A modellek regressziós diagnosztikájával igazoltam azok megbízhatóságát.

7. Elsőként határoztam meg három külföldi kajszifajta ('Sylvercot', 'Pinkcot', 'Veecot') egészségmegőrzés szempontjából fontos ß-karotin és polifenol értékeit. Gyümölcseik átlagos polifenol-tartalma harmada a 'Gönci magyar kajszi'-énak. A 'Sylvercot', 'Pinkcot' ß-karotin-tartalma alacsonyabb, mint a 'Gönci magyar kajszi'-é, a 'Veecot' fajtáé pedig azzal közel megegyező. 


\section{8. ÖSSZEFOGLALÁS}

Magyarországon a kajszi nem őshonos, ennek ellenére több évszázados hagyománya van a termesztésének. Elsődleges géncentruma Kína területén található, Európa területére kb. 2000 éve érkezett meg. A magyarországi fajtahasználatról elmondható, hogy a régebbi ültetvényekben a magyar fajták túlsúlya jellemző, de az új ültetvényekben a külföldön nemesített fajták telepítési aránya már jelentősebbé vált a hazaiakénál. Ennek valószínüleg az az oka, hogy az utóbbi években az áruértékkel szembeni követelmények megváltoztak, valamint az érési szezon meghosszabbításának igénye is felerösödött.

A hazánkban termesztett gyümölcsfajok közül a kajszi az egyik legfagyérzékenyebb. Termésbiztonságát a téli és a tavaszi fagykárok jelentősen befolyásolják. A kajszifajták értékelésének fontos szempontja ezért az áttelelő szerveik fagytürő képességének meghatározása. Az ültetvények fajtaösszetétele és a termőhely helytelen megválasztása miatt gyakori a terméskiesés és nagy a termésmennyiség évenkénti ingadozása Magyarországon. A kajszi gyümölcse a külföldi piacokon jól értékesíthető, ahol csak a kiváló minőségü, tetszetős, jól színeződő, nagy gyümölcsü, jól szállítható és pultontartható fajtákkal lehetünk versenyképesek. A jó piaci pozíciók eléréséhez a termesztett fajták érésbiológiai jellemzőit és gyümölcsminőségi paramétereit a lehető legrészletesebben kell ismernünk. A fajtaválaszték folyamatos fejlesztésre, bővítésre szorul, amiben nagyon fontos szerepe van egyfelől a hazai nemesítői munkának, másfelől a külföldön nemesített új kajszifajták honosításának. Olyan fajtákkal kell bővíteni a fajtaválasztékot, melyek jó fagy- és téltürésüek, hosszú mélynyugalmúak, kiváló gyümölcsminőségüek.

A fentiek tükrében célul tűztük ki a termesztés számára ígéretesnek tűnő külföldi kajszifajták fagytürésének, mikrosporogenézisük ütemének, fizikai és kémia tulajdonságainak, valamint egészségvédő értékeinek vizsgálatát. Kutatómunkánk bázisát a Gyümölcstermő Növények Tanszék génbanki fajtagyüjteménye, valamint tematikus laboratóriumai képezték.

A fagytürési vizsgálatok során részletesen megvizsgáltuk 12 külföldi kajszifajta fagytürésének alakulását a téli nyugalmi időszakban. Kontrollként a fagyérzékeny 'Ceglédi bíborkajszi', a közepesen fagytürő 'Gönci magyar kajszi', valamint a fagytürő 'Rózsakajszi C.1406.' fajtákat használtuk. Jelentős különbségeket találtunk a fajták fagyállóságának alakulásában. A külföldi fajták közül kiemelkedő fagytüréssel a 'Harlayne' rendelkezett, a többi közepesen fagytürőnek, illetve fagyérzékenynek bizonyult a három standard fajtához viszonyítva. Ezeket csak védett, fagyzugoktól mentes termőhelyre ajánljuk. 
Vizsgálataink során az évjáratok között csak kisebb különbségeket tapasztaltunk a téli fagytürésben, szignifikáns évjárathatást nem volt kimutatható, a fajtahatás viszont szignifikáns volt. A virágrügyek fagyállósága az edződési folyamat során fokozatosan alakult ki. Az edződés mértékét a külső hőmérséklet változása befolyásolta. A tél második felében fokozatosan vesztették el a virágrügyek a fagytürőképességüket, a csökkenés üteme nagymértékben függött a hőmérséklet változásától.

Hazánk területén a legjelentősebb problémát a virágzáskori fagykárok okozzák, ezért három évjáratban mesterséges fagyasztásos kísérletekkel megvizsgáltuk három magyar fajta fagytürésének alakulását is. Szignifikáns évjárat- és fajtahatást tudtunk kimutatni.

A mikrosporogenézis folyamatát a három éves vizsgálati időszakban $5 \mathrm{db}$ ÉszakAmerikában és 3 db Romániában nemesített kajszifajtánál vizsgáltuk a Magyarországon árutermelő ültetvényekben legelterjedtebb, közepes fagy- és télállóságú 'Gönci magyar kajszi' fajtát használva kontrollként. Vizsgálati eredményeink alapján sorrendbe állítottuk a vizsgált fajtákat mikrosporogenézisük üteme szempontjából. Mind a három évben azonos sorrend alakult ki. Ez egyben a termésbiztonságot jelző sorrendnek is tekinthető. Az élen szereplő 'Pinkcot' virágrügyeinek mélynyugalma már január 10. és 25 . közötti időszakban véget ért, míg a sorrend végén lévő 'Harlayne' fajtáé csak február 5 és 10 között. A vizsgált fajták között háromnak a virágrügyfejlődése bizonyult gyorsabbnak a kontrollénál, ezek sorrendben a 'Pinkcot', az 'Orange Red' és a 'Harcot'. Ezek termesztése nagyobb kockázattal jár Magyarországon, a gyors téli virágrügyfejlődésük miatt. A ‘Gönci magyar kajszi’-nál lassúbb virágrügyfejlődésűek, tehát nagyobb biztonsággal termeszthetők sorrendben a vizsgálataink szerint a következők: 'Litoral', 'Harogem', 'Comandor', 'Sirena' és 'Harlayne'.

A nemzetközi piacokon egyre komolyabb elvárások jelentkeztek a kajszi gyümölcsét illetően, csak kiváló minőségű, nagy gyümölcsmérettel rendelkező, jól szállítható és pultontarható kajszifajtákra van kereslet. Vizsgálataink során célul tüztük ki két különböző évjáratban a kajszifajták áruértékét meghatározó fizikai és kémiai paramétereinek részletes vizsgálatát. Eredményeink alapján elmondható, hogy a külföldi fajták közül a 'Goldrich', a 'Pinkcot', a 'Sylvercot', a 'Bergarouge' és a 'Veecot' gyümölcstömege megfelel a piaci követelményeknek, nagy gyümölcsméretet produkáltak.

A húskeménység nagyon fontos fizikai paraméter, jelentősen meghatározza a gyümölcsök szállíthatóságát és pultontarthatóságát. Vizsgálataink során kiemelkedő húskeménységi értékeket a 'Veecot', az 'Orange Red', a 'Laycot', a 'Hargrand' és 'Harogem' esetében mértünk. A többi külföldi fajtáról elmondható, hogy a magyar fajtákhoz viszonyítva 
nagyobb a húskeménységük a műszeres mérések alapján. Elvégeztük a három húskeménység mérésére alkalmas módszer összehasonlítását is, s eredményeinkből arra következtettünk, hogy a müszeres mérési módszer, tủ alakú mérőfejet használva precízebb eredményt ad, mint a másik két módszer, ezáltal kutatási célokra jobban használható.

A gyümölcsök fogyasztói megítélésében jelentős szerepet tölt be a cukrok és savak mennyiségi aránya, amely a gyümölcsök harmonikus ízét adja. Vizsgálati eredményeink alapján magas cukortartalmat 90\%-os érettségben a magyar kajszifajtáknál mértünk ('Budapest', 'Gönci magyar kajszi’, 'Mandulakajszi’), a külföldi fajták közül a magyar kajszikhoz hasonlóan magas cukortartalommal rendelkeztek a 'Bergarouge', a 'Harcot', a 'Litoral'; valamint a 'Veecot'. A savtartalom alakulása tekintetében a két vizsgálati év alapján elmondható, hogy a 'Harogem', a 'Litoral', a 'Veecot', a 'Sylvercot', valamint a 'Goldrich' savtartalma hasonlóan alakult a magyar fajtákéhoz, vagy egy kicsit meg is haladták azt. A 'Gönci magyar kajszi’-hoz hasonlóan a 'Harogem' esetében mértünk kiegyensúlyozott cukor/sav arányt. Kiemelkedő cukor/sav aránnyal az 'Orange Red' rendelkezett, amely a viszonylag alacsony cukor- és az igen alacsony savtartalomból adódott.

Elvégeztük négy kajszifajta esetében az egészségmegőrzés szempontjából jelentős $ß$ karotin- és polifenol-tartalom vizsgálatát is. Kiemelkedő polifenol- és ß-karotin- tartalmat mértünk mind a két évben a 'Gönci magyar kajszi' gyümölcseiben. A külföldi fajták közül a 'Veecot' ß-karotin-tartalma a magyar fajtához hasonló volt. A polifenol-tartalom a külföldi fajták gyümölcsében kisebb volt a kontroll fajtához viszonyítva.

Mindent összevetve kijelenthető, hogy a kajszifajták termésbiztonságával és piaci értékeik meghatározásával kapcsolatos területeken kívántuk bővíteni az ismereteket új kutatási eredményekkel. 


\section{SUMMARY}

However Apricot is not indigenous in Hungary, the tradition of apricot growing in the country dates back several hundred years. The primary center of origin of apricot is in China, and it was brought to Europe approximately two thousand years ago. In Hungary, the cultivar assortment of older orchards is ruled by Hungarian cultivars; however, the new plantations are dominated by cultivars which were developed in other countries. The reason of this might be that over the last few years, consumer preferences have changed, as well as there is an increasing demand for cultivars which are suitable for extending the season.

Apricot is one of the most frost-sensitive fruit species grown in Hungary. The yield security of apricot is greatly affected by the frost injuries of winter and springtime. Therefore, determining the frost tolerance of the overwintering organs is a very important aspect of the evaluation of apricot cultivars. Yield loss occurs frequently in case of unsuitable production site or cultivar use, resulting in large fluctuations in the annual yield of Hungary. There is a huge demand for apricot fruits on the international market, but only the excellent quality, appealing, well-colored, large-sized, well-transportable and well-storable fruits are competitive. To achieve a good position in the market, we have to know the maturation processes and fruit quality parameters of the cultivars as detailed as possible. The Hungarian assortment of apricot cultivars should be widened, which can be achieved by local breeding work, or by introducing foreign cultivars to the country. Cultivars having good frost and winter tolerance, long dormancy period, and excellent fruit quality are needed for widening the assortment.

In light of the above, we aimed to examine the frost tolerance, phenological processes, health benefits, and the physical and chemical characteristics of promising new apricot cultivars. The fruit cultivar collection and the fruit analytical laboratories of the Department of Pomology formed the basis of the research work.

The frost tolerance development of twelve foreign apricot cultivars was examined during the dormancy period in the winter. The frost-sensitive 'Ceglédi bíborkajszi', the moderately frost-tolerant 'Gönci magyar kajszi' and the frost-tolerant 'Rózsakajszi C.1406.' were used as reference cultivars. There were significant differencies in the frost tolerance of the cultivars. Among the foreign cultivars 'Harlayne' had outstanding frost-tolerance, while the rest of them were moderately frost-tolerant, or frost-sensitive, in comparision to the three reference cultivars. These cultivars can only be suggested in the case of safe production site, which is free of risky low-altitude areas. 
No signifacant vintage effect could be concluded, only minor differences were experienced in frost hardiness, compearing the data of different years; however, the frost hardiness varied significantly depending on the cultivar.. The frost hardiness of the flower buds developed gradually during the hardening. The intensity of training is influenced by the change of the outer temperature. In the second half of winter the flower buds gradually lost their frost hardiness. The decreasing tendency showed strong correlation with the change of the temperature.

In Hungary, the most serious problem is caused by the frost injuries in springtime, therefor in a three year period, we carried out artificial freezing experiments to study the changeing frost tolerance of the three reference cultivars. Significant effect of vintage or cultivar could be shown, in the three years of the study.

Over a three-year period the phenological processes of five cultivars from North America and three from Romania were analysed, using the cultivar 'Gönci magyar kajszi' as a reference cultivar, which has moderate frost tolerance and winter hardiness and is grown widely in commercial orchards in Hungary. On the basis of the results, the cultivars were ranked in terms of the schedule of microsporogenesis. Almost the same order was observed in all three years, and this order can be regarded as indicative of the yield safety of cultivars. The end of endodormancy in the flower buds was recorded between January 10 th and 25 th for the first-ranking cultivar 'Pinkcot', but not before February 5-10 th for the last cultivar, 'Harlayne'. Three of the tested cultivars had faster flower bud development than the reference cultivars ('Pinkcot', 'Orange Red' and 'Harcot', in this order), indicating that their cultivation would be riskier than that of 'Gönci magyar kajszi' in Hungary, due to their rapid flower bud development in winter. Cultivars found to have slower flower bud development than 'Gönci magyar kajszi' (in the order 'Litoral', 'Harogem', 'Comandor', 'Sirena' and 'Harlayne') could be grown with less risk in Hungary.

The expectations of the international market for apricot fruits is getting to be higher, only excellent quality, large sized, well-transportable and well-storable apricot cultivars are in demand. One of the aims of this study was to examine the physical and chemical parameters of the apricot cultivars in detail, which are determining the market value of the cultivars. Based on our results, the fruit weight of 'Goldrich', 'Pinkcot', 'Sylvercot', 'Bergarouge' and 'Veecot' meets the requirements of the market; these cultivars produced large sized fruits.

The transport, packige, and storage of fruits is basically determined by flesh firmness, which is, hence, a very important physical parameter. Outstanding fruit firmness values were 
measured in the case of 'Veecot', 'Orange Red', 'Laycot', 'Hargrand', and 'Harogem'. Based on the measurements, the rest of the foreign cultivars also had more firm flesh than the Hungarian cultivars. Three flesh firmness measurement methods were also compared. It was concluded, that the needle probe gives the most precise result in comparision with the other two kind of cylinder probes, thus it is more suitable for research studies.

The proportion of sugars and acids of fruits have a significant role in consumer acceptance, and is responsible for the harmonic taste of fruits. Based on our results, the Hungarian apricot cultivars have high sugar content at 90\% maturity ('Budapest', 'Gönci magyar kajszi', and 'Mandulakajszi'). Similarly high sugar content was measured in some of the forign cultivars, such as the 'Bergarouge', 'Harcot', 'Litoral', and 'Veecot'. On the basis of two-year data 'Harogem', 'Litoral', 'Veecot', 'Sylvercot', and 'Goldrich' have similar acid content in comparition with the Hungarian cultivars, or even exceeded their values. Higher sugar/acid ratio refers to higher fruit quality. Similarly to 'Gönci magyar kajszi', harmonic acid/sugar ratio was measured in 'Harogem'. However the sugar content of 'Orange Red' was relatively low, it had very low acid content, resulting in an outstandingly high sugar/acid ratio.

High $\beta$-carotin and poliphenol content have significant health benefits, thus they were also measured in case of four apricot cultivars. In both years we measured outstanding poliphenol and $\beta$-carotin content in 'Gönci magyar kajszi'. Among the foreign cultivars 'Veecot' had high ß-carotin content, similar to the Hungarian cultivars did. The poliphenol content of the foreign cultivars were lower than the Hungarian cultivars.

Our intention was to widen our knowledge with new research results, on the fields of yield security and market value of apricot cultivars. 


\section{MELLÉKLETEK}

\section{M1: Irodalomjegyzék:}

1. ABBOTT J.A. (1999): Quality measurement of fruits and vegetables. Postharvest Biol Tech, 15 (3) 207-225. p. doi:10.1016/S0925-5214(98)00086-6

2. ANDREINI L., VITI R., BARTOLINI S., RUIZ D., EGEA J., CAMPOY J.A. (2012): The relationship between xilem differentiation and dormancy evoluation in apricot flower buds (Prunus armeniaca L.): the influence of environmental conditions in two Mediterranean area. Trees, 26 (3) 919-928. p. doi: 10.1007/s00468-011-0668-1

3. AHMAD R., POTTER D., SOUTHWICK S.M. (2004): Identification and characterization of plum and pluot cultivars by microsatellite markers. J Hortic Sci Biotech 79 (1): 164-169. p. http://cat.inist.fr/?aModele=afficheN\&cpsidt=15437709

4. ALBURQUERQUE N., BURGOS L., EGEA J. (2004): Influence of flower bud density, flower bud drop and fruit set on apricot productivity. Sci Hortic-Amsterdam, 102 (4) 397406. p. doi:10.1016/j.scienta.2004.05.003

5. AKIN E.B., KARABULUT I., TOPCU A. (2008): Some compositional properties of main Malaty apricot (Prunus armeniaca L.) varieties. Food Chem, 107 (2) 939-948. p. doi:10.1016/j.foodchem.2007.08.052

6. ANDERSEN Ø.M., MARKHAM K.R. (Szerk.) (2006): Flavonoids: chemistry, biochemistry and applications. Boca Raton: CRC Press. 1197 p. http://blogs.cimav.edu.mx/daniel.glossman/data/files/Libros/Flavonoids\%20\%20Chemistry,\%20Biochemistry\%20and\%20Applications.pdf

7. ANET E.F.L.J., REYNOLDS T.M. (1955): The separation of acids on anion exchange resins: The isolation of 1-quinic acid from apricots. Aust J Chem, 8 (2) 267-275. p. doi:10.1071/CH9550267

8. ASMA B.M., OZTURK K. (2005): Analysis of morphological, pomological and yield characteristics of some apricot germplasm in Turkey. Genet Resour Crop Ev, 52 (3) 305313. p. doi:10.1007/s10722-003-1384-5

9. ASMA B.M., TUNCAY K., BIRHANLI O. (2007): Characterization of promising apricot (Prunus armeniaca L.) genetic resources in Malatya, Turkey. Genet Resour Crop Ev, 54 (1) 205-212. p. doi: 10.1007/s10722-005-3809-9

10. ASMA B.M. (2007): Malaty: World's Capital of apricot culture. Chron Hortic, 47 (1) 2024. p. http://malatyaapricots.com/bazimakaleler/Chronica\%20hort.pdf 
11. ASMA B.M. (2012): A new early-ripening apricot, 'Dilbay'. HortScience, 47 (9) 13671368. p. http://hortsci.ashspublications.org/content/47/9/1367.full

12. ASCHWORTH E.N., ROWSE D.J., BILLMYER L.A. (1983): The freezing of water in woody tissues of apricot and peach and the relationship to freezing injury. J Am Soc Hortic Sci, 108 (2) 299-303. p. http://www.citeulike.org/user/sylvirgro/article/7215616

13. AUBERT C., BONY P., CHALOT G., HERO V. (2010): Changes in physiochemical characteristics and volatile compounds of apricot (Prunus armeniaca L. cv Bergeron) during storage and post-harvest maturation. Food Chem, 119 (4) 1389-1398. p. doi:10.1016/j.foodchem.2009.09.018

14. AZODANLOU R., DARBELLAY C., LUISIER J., VILLETAZ J., AMADÓ R. (2003): Development of a model for quality assessment of tomatoes and apricots. Food Sci Technol-Leb, 36 (2) 223-233. p. doi:10.1016/S0023-6438(02)00204-9

15. BADENES M.L., MARTINEZ-CALVO J., LLÁCER G. (1998): Analysis of apricot germplasm from the European ecogeographical group. Euphytica, 102 (1) 93-99. p. doi: 10.1023/A:1018332312570

16. BAILEY C.H., COWGILL W., HOUGH L.F. (1981): Estimate of chilling requirements of apricot selections. Acta Hortic, 85 184-189. p. 10.17660/ActaHortic.1981.85.41

17. BANAINÉ B. (1981): Kajszi F1 hibridek populációgenetikai értékelése. Doktori értekezés, Budapest: KÉE.

18. BARTOLINI S., VITI R. (1999): Histological studies on flower buds of cultivars 'Stark Early Orange'. Acta Hortic, 488 335-339. p. doi: 10.17660/ActaHortic.1999.488.52

19. BARTOLINI S., VITI R., GUERRIERO R. (2006a): Xilem differentiation and microsporogenesis during dormancy of apricot flower buds (Prunus armeniaca L.). Eur J Hortic Sci, 71 (2) 84-90. p. http://www.jstor.org/stable/24126693

20. BARTOLINI S., VITI R., LAGHEZALI M., OLMEZ HA. (2006b.): Xilem vessel differentiation and microsporogenesis evolution in 'Canino' cultivar growing in three different climatic areas, Italy, Marocco and Turkey. Acta Hortic, 701 135-140. p. http://dx.doi.org/10.17660/ActaHortic.2006.701.18

21. BARTOLINI S., ZANOL G., VITI R. (2006c): The cold hardiness of flower buds in two apricot cultivars. Acta Hortic, 701 141-146. p. doi: 10.17660/ActaHortic.2006.701.19

22. BASSI R., PINEAU B., DAINESE P., MARQUARD J. (1992): Carotenoid binding proteins of Photosystem II. Eur J Biochem, 212 (2) 297-303. p. DOI: 10.1111/j.14321033.1993.tb17662.x 
23. BASSI D., BARTOLINI S., VITI R. (2006): Recent advences on environmental and physiological challenges in growing apricot. Acta Hortic, 717 23-31. p. http://dx.doi.org/10.17660/ActaHortic.2006.717.1

24. BETTINI O. (2013a): Italy, Stone fruit annual 2013. http://gain.fas.usda.gov/Recent\%20GAIN\%20Publications/Stone\%20Fruit\%20Annual\%202013_R ome_Greece_10-28-2013.pdf

25. BETTINI O. (2013b): Greece, Stone fruit annual 2013. http://gain.fas.usda.gov/Recent\%20GAIN\%20Publications/Stone\%20Fruit\%20Annual\%202013_R ome_Greece_10-28-2013.pdf

26. BITTENBENDER H.C., HOWELL G.S.JR. (1974): Adaptation of the Spearman-Karber method for estimating the $\mathrm{T}_{50}$ of cold stress flower buds. J Am Soc Hortic Sci, 99 (2) 187190. p. http://agris.fao.org/agris-search/search.do?recordID=US201303135920

27. BÍRÓ GY., LINDNER K. (1999): Tápanyagtáblázat. 12. átdolgozott, bővített kiadás. Budapest: Medicina Könyvkiadó Rt.

28. BHAT M.Y., PADDER B.A., WANI I.A., BANDAY F.A., AHSAN H., DAR M.A., LONE A. (2013): Evaluation of apricot cultivars based on physicochemical characteristics observed under temperate conditions. Int J Agr Sci, 3 (5) 534-537. p. http://internationalscholarsjournals.org/download.php?id=784892578815951448. pdf\&type=ap plication/pdf\&op=1

29. BORSA B., FEKETE A., FELFÖLDI J. (2002): Kertészeti termékek mechanikai és minőségi jellemzői. Gödöllő: FVM Műszaki Intézet közleménye. 16 (2) 1-7. p. http://www.fvmmi.hu/file/document/kiadv/572_zold-41-2.pdf

30. BOULNOIS K. (1972): A Selyemút. Budapest: Kossuth Kiadó. 200. p.

31. BOURNE M.C., MOYER J.C., HAND D.B. (1966): Measurement of food texture by an universal testing machine. Food Technology, 20 (4) 522. p.

32. BOURNE M.C. (1978): Texture profile analysis. Food Technology, 32 62-66, 72. p.

33. BOURNE M.C. (1982): Food Texture and Viscosity. New York: Academic Press. 330. p.

34. BRUHN C.M., FELDMAN N., GARLITZ C., HARWOOD J., IVANS E., MARSHALL M. (1991): Consumer perceptions of quality: apricots, cantaloupes, peaches, pears, strawberries and tomatoes. J Food Quality, 14 (3) 187-195. p. DOI: 10.1111/j.17454557.1991.tb00060.x

35. BROWN D.S, KOTOB F.A. (1957): Growth of flower buds of apricot, peach and pear during the rest period. Proceedings of the American Society of Horticulture Science, 69 158-164. p. 
36. BRÓZIK S. (1960): Termesztett gyümölcsfajtáink 2. Csonthéjastermésűek. Szilva, kajszi. Budapest: Mezőgazdasági Kiadó.

37. BUBÁN T. (2003): A virágrügyek képződése. 131-157. p. In: PAPP J. (Szerk.): Gyümölcstermesztési alapismeretek. Budapest: Mezőgazda Kiadó, 472. p.

38. BUREAU S., CHAHINE H., REICH M., ALBAGNAC G. (2006): Fruit ripening of contrasted apricot varieties: physical, physiological and biochemical changes. Acta Hortic, 701 511-515. p. http://dx.doi.org/10.17660/ActaHortic.2006.701.88

39. BUREAU S., RUIZ D., REICH M., GOUBLE B., BERTRAND D., AUDERGON J.M., RENARD C.M.G.C. (2009): Application of ATR-FTIR for a rapid and simultaneous determination of sugars and organs acids in apricot fruits. Food Chem, 115 (3) 11331140. p. doi:10.1016/j.foodchem.2008.12.100

40. BURR K.E., WALLNER S.J., TINUS R.W. (1993): Heat tolerance, cold hardiness, and bud dormancy relationships in seedlings of selected conifers. J Amer Soc Hort Sci, 118 (6) 840-844. p. http://journal.ashspublications.org/content/118/6/840.full.pdf

41. CAMPBELL O.E., PADILLA-ZAKOUR O.I. (2013): Phenolic and carotenoid composition of canned peaches (Prunus persica) and apricots (Prunus armeniaca) as affected by variety and peeling. Food Res Int, 54 (1) 448-455. p. doi:10.1016/j.foodres.2013.07.016

42. CANTIN C.M., MORENO M.A. GOGORCENA, Y. (2009): Evaluation of the antioxidant capacity, phenolic compounds, and vitamin $\mathrm{C}$ content of different peach and nectarine [Prunus persica L. Batsch] breeding progenies. J Agr Food Chem, 57 (11) 4586-4592. p. http://pubs.acs.org/doi/abs/10.1021/jf900385a

43. CHEYNIER V. (2012): Phenolic compounds: from plants to foods. Phytochemistry Reviews, 11 (2) 153-177. p. doi: 10.1007/s11101-012-9242-8

44. COCIU V. (1982): New apricot varieties breeded in Romania. Acta Hortic, 121 211-216. p. http://dx.doi.org/10.17660/ActaHortic.1983.121.24

45. COCIU V., HOUGH L.F. (1985). Germ plasm of apricot and some suggestion for its use. Acta Hortic, 192 291-297. p. http://dx.doi.org/10.17660/ActaHortic.1986.192.45

46. COCIU V. (1991): Forty years of apricot breeding of Romania. Acta Hortic, 293 197201. p. http://dx.doi.org/10.17660/ActaHortic.1991.293.20

47. COCIU V. (2006): 50 years of apricot varieties breeding in Romania. Acta Hortic, 701 355-358. p. http://dx.doi.org/10.17660/ActaHortic.2006.701.57

48. CODEX ALIMENTARIUS HUNGARICUS 3-1-558/93:1995 Élelmiszerek vízoldható szárazanyag-tartalmának meghatározása. 
49. CONTE L., NICOTRA A., SARTORI A. (2010): Results of an apricot breeding programme at the CRA-FRU. Acta Hortic, 862: 99-101. p. http://dx.doi.org/10.17660/ActaHortic.2010.862.14

50. COSTA G., NOFERINI M., FIORI G., BERTHOD N., BESSE S., ROSSIER J. (2012): Methods to assess fruit quality focusing on non-destructive methods. Acta Hortic, 966 275-284. p. http://dx.doi.org/10.17660/ActaHortic.2012.966.44

51. CROSSA-RAYNAUD P., AUDERGON J.M. (1991): Some reflexions on apricot selections. Acta Hortic, 293 73-85. p. http://dx.doi.org/10.17660/ActaHortic.1991.293.7

52. D'AGOSTINO R.B., BELANGER A., D'AGOSTINO R.B. JR. (1990): A suggestion for using powerful and informative tests of normality. The American Statistician, 44 (4) 316 321. p. http://www.tandfonline.com/doi/abs/10.1080/00031305.1990.10475751

53. DARNAUD J.P. (2013): Szóbeli közlés. http://www.ipsplant.com/wwwuk/gamme.php?ID=1

54. DE CANDOLLE A. (1894): Termesztett növényeink eredete. Budapest: K.M. Természettudományi Társulat. 515. p.

55. DENCKER I., HANSEN P. (1994): Flower initation and node development of axillary buds, growth partitioning, and bleeding sap production of young apple trees as affected by fertigation. J Hortic Sci, 69 (5) 869-876. p. doi: 10.1080/14620316.1994.11516523

56. DENNIS F. G. JR. (1994): Dormancy - What we know (and don't know). HortScience, 29 (11) 1249-1253. p. http://hortsci.ashspublications.org/content/29/11/1249.full.pdf

57. DOYMAZ I. (2004): Effect of Pre-treatments using Potassium Metabisulphide and Alkaline Ethyl Oleate on the Drying Kinetics of Apricots. Biosystems Engineering, 89(3):281-287. doi:10.1016/j.biosystemseng.2004.07.009

58. DRAGOVIC-UZELAC V., DELONGA K., LEVAJ B., DJAKOVIC S., POSPISIL J. (2005): Phenolic profiles of raw evaluation of apricot nectar and jam authenticity. $J$ Agr Food Chem, 53 (12) 4836-4842. p. doi: 10.1021/jf040494+

59. DRAGOVIC-UZELAC V., LEVAJ B., MRKIC V., BURSAC D., BORSAS M. (2007): The content of polyphenols and carotenoids in three apricot cultivars depending on stage of maturity and geographical region. Food Chem, 102 (3) 966-975. p. doi:10.1016/j.foodchem.2006.04.001

60. DRÉN G., THURZÓ S., SZABÓ Z., RACSKÓ J., DANI M., HERMÁN R., SOLTÉSZ M., NYÉKI J. (2005): Kajszibarackfajták fagytűrő képességének változása és tényezői. 89-94. p. In: TÓTH M. (Szerk.): A fajtaválaszték fejlesztése a kertészetben. Budapest: Magyar Mezőgazdaság $\quad$ Kft. 270. p. $\quad$ http://www.uni- 
corvinus.hu/fileadmin/user_upload/hu/kerteszettudomanyi_kar/kertgazdasag/files/2005_kulon szam/2005kulonszam_gyumolcstermo_novenyek9.pdf

61. EGEA J., DICENTA F., BURGOS L. (2004): ‘Rojo Pasión' apricot. HortScience, 39 (6) 1490-1491. p. http://hortsci.ashspublications.org/content/39/6/1490.full.pdf

62. ERDOGAN-ORHAN I., KARTAL M. (2011): Insights into research on phytochemistry and biological activities of Prunus armeniaca L. (apricot). Food Res Int, 44 (5) 12381243. p. doi:10.1016/j.foodres.2010.11.014

63. ERDÖS Z., KEREK M.M., SZANI ZS. (2010): Államilag elismert új kajszibarackfajták: Ceglédi napsugár, Nyujtó Ferenc emléke. Kertgazdaság, 42 (3-4) 16-24. p. http://kertgazdasag.unicorvinus.hu/fileadmin/user_upload/hu/kerteszettudomanyi_kar/kertgaz dasag/files/2010_03_04/2010_3_4_Gyumolcstermesztes1.pdf

64. FAO (Food and Agriculture Organization of the United Nation) (2013): FAOSTAT http://www.faostat.fao.org/

65. FARINA V., VOLPE G., MAZZAGLIA A., LANZA C.M. (2010): Fruit quality traits of two apricot cultivars. Acta Hortic, 862 593-598. p. http://dx.doi.org/10.17660/ActaHortic.2010.862.94

66. FAUST M. (1989): Physiology of temperate zone fruit trees. New York: John Wiley and Sons. 232 p.

67. FAUST M., EREZ A., ROWLAND L.J., WANG S.Y., NORMAN H.A. (1997): Bud dormancy in perennial fruit trees: phisiological basis for dormancy induction, maintance and $\quad$ release. HortScience, $32 \quad$ (4) 623-629. p. http://hortsci.ashspublications.org/content/32/4/623.full.pdf+html

68. FAUST M., SURÁNYI D., NYUJTÓ F. (1998): Origin and dissemination of apricot. 225-266. p. In: JANICK J. (Szerk.): Horticultural Reviews. New York: John Wiley \& Sons, Inc. 231 p. DOI: 10.1002/9780470650738.ch6

69. FERGUSON J.C., TARARA J.M., MILLS L.J., GROVE G.G., KELLER M. (2011): Dynamic thermal time model of cold hardiness for dormant grapevine buds. Ann Bot, 107 (3) 389-396. p. http://www.ncbi.nlm.nih.gov/pmc/articles/PMC3043938/

70. FERRERES F., GOMES D., VALENTÁO P., GONCALVES R., RIO R., ALVES E., SEABRE R.M., ANDRADE P.B. (2009): Improved loquat (Eryobotrya japonica Lindl.) cultivars: variation of phenolics and antioxidative potential. Food Chem, 114 (3) 10191027. p. doi:10.1016/j.foodchem.2008.10.065

71. FICZEK G., STÉGERNÉ MÁTÉ M., NÓTIN B., TÓTH M. (2011): Changing of texture and pectin content of Hungarian bred apple genotypes during the storage. Food Process Engineering in a Changing World. ICEF11 International Congress on Engineering and 
Food. 2011 május 22-26., Athens, Greece. http://www.icef11.org/content/papers/fms/FMS1225.pdf

72. FLINN C.L., ASHWORTH E.N. (1999): Supercooling in dormant flower buds of Forsythia, and the correlation between pistil size and bud hardiness. J Environ Hort, 17

http://www.hriresearch.org/docs/publications/JEH/JEH_1999/JEH_1999_17_2/JEH\%2017-2-5762.pdf

73. FRASER P.D., BRAMLEY P.M. (2004): The biosynthesis and nutritional uses of carotenoids. Prog Lipid Res, 43 (3) 228-265. p. doi:10.1016/j.plipres.2003.10.002

74. FRUITVEB (2012): Magyar Zöldség-Gyümölcs Szakmaközi Szervezet és Terméktanács. http://www.fruitveb.hu/

75. FRUITVEB (2013): Magyar Zöldség-Gyümölcs Szakmaközi Szervezet és Terméktanács. http://www.fruitveb.hu/

76. GARCIA-VIGUERA C., BRIDLE P., FERRERES F., TOMAS-BARBERAN F.A. (1994): Influence of variety, maturity and processing on phenolic compounds of apricot juices and jams. Z Lebensm Unters Forsch, 199 (6) 433-436. p. doi:10.1007/BF01193268

77. GARCIA-VIGUERA C., ZAFRILLA P., TOMAS-BARBERAN F.A. (1997): Determination of authenticity of fruit jams by HPLC analysis of anthocyanins. J Sci Food Agr, $73 \quad$ (2) 207-213. p. doi: 10.1002/(SICI)1097-0010(199702)73:2<207::AIDJSFA703>3.0.CO;2-8

78. GHORPADE V.M., HANNA M.A. (1995): 'Apricots'. 335-361. p. In: SALUNKHE, D.K., KADAM, S.S. (Szerk.): Handbook of fruit Science and Technology: Production, Composition, Storage and Processing. New York: Marcel Dekker. 632. p. https://books.google.hu/books/about/Handbook_of_Fruit_Science_and_Technology.html?id=v 2WnS_2ZmDwC\&redir_esc $=y$

79. GILMOUR S.J., ZARKA D.G., STOCKINGER E.J., SALAZAR M.P., HOUGHTON J.M., THOMASHOW M.F. (1998): Low temperature regulation of the Arabidopsis CBF family of AP2 transcriptional activators as an early step in cold-induced COR gene expression. The plant Journal, 16 (4) 433-442. p. DOI: 10.1046/j.1365-313x.1998.00310.x

80. GÓMEZ E., LEDBETTER C.A. (1997): Development of volatile compounds during fruit maturation: Characterization of apricot and plum x apricot hybrids. J Sci Food Agri, 74 (4) 541-546. p. http://handle.nal.usda.gov/10113/48425

81. GONDA I., VASZILY B. (2014): Gyümölcstermesztés. Debreceni Egyetemi Kiadó. 82. p. https://dea.lib.unideb.hu/dea/bitstream/handle/2437/196474/Gyumolcstermesztes_Gonda.pdf 
82. GRAETZ D.K. (2006): Breeding apricot cultivars for drying in Australia. Acta Hortic, 717 197-198. p. 10.17660/ActaHortic.2006.717.41

83. GU S. (1999): Lethal temperature coefficient - a new parameter for interpretation of cold hardiness. J Hortic Sci Biotech, 74 (1) 53-59. p. doi: 10.1080/14620316.1999.11511071

84. GUERRIERO R. (1982): La coltura de la albicocco atti del Convergo. Prospettive per l' Agricoltura Collinare Fiorentina. 1 (27-28) 93-116. p.

85. GUERRIERO R., AUDERGON J.M., MARTINEZ C.A. (1988): Apricot cultivars for Mediterranean climate. Acta Hortic, 209 39-47. p. http://dx.doi.org/10.17660/ActaHortic.1988.209.4

86. GUERRIERO R., VITI R., BARTOLINI S., LACONA C. (2006): Parent for Spring Frost Tolerance in Apricot. Acta Hortic, 717 153-156. p. http://dx.doi.org/10.17660/ActaHortic.2006.717.31

87. GUNES N.T. (2006): Frost hardiness of some Turkish apricot cultivars during the bloom period. HortScience, 41 (2) $\quad$ : 310-312. p. http://hortsci.ashspublications.org/content/41/2/310.abstract

88. GUSTA L.M., WISNIEWSKI M. (2013): Understanding plant cold hardiness: an opinion. Physiologia Plantarium, 147 (1) 4-14. p. DOI: 10.1111/j.1399-3054.2012.01611.x

89. HAGEN L., KHADARI B., LAMBERT P., AUDERGOS J.M. (2002): Genetic diversity in apricot revealed by AFLP markers: species and cultivar comparisons. Theor Appl Genet, 105 (2-3) 298-305. p. DOI 10.1007/s00122-002-0910-8

90. HAMINIUK C.W.I., MACIEL G.M., PLATA-OVIEDO M.S.V., PERALTA R.M. (2012): Phenolic compound in fruits- an overview. Int J Food Sci Tech, 47 (10) 2023 2044. p. DOI: $10.1111 / j .1365-2621.2012 .03067 . x$

91. HARBORNE J.B., WILLIAMS C.A. (2000): Advances in flavonoid research since 1992. Phytochemistry, 55 (6) 481-504. p. doi:10.1016/S0031-9422(00)00235-1

92. HATCH A.H., WALKER D.R. (1969): Rest intensity of dormant peach and apricot leaf buds as influenced by temperature, cold hardiness and respiration. J Am Soc Hortic Sci, 94 (3) 304-307. p.

93. HEGEDÜS A., ENGEL R., ABRANKÓ L., BALOGH E., BLÁZOVICS A., HERMÁN R., HALÁSZ J., ERCISLI S., PEDRYC A., STEFANOVICS-BÁNYAI É. (2010): Antioxidant and antiradical capacities in apricot (Prunus armeniaca L.) fruits: variations from genotypes, years and analytical methods. J Food Sci, 75 (9) C722-C730. p. doi: DOI: 10.1111/j.1750-3841.2010.01826.x 
94. HEGEDÜS A. (2013): A csonthéjas gyümölcsök antioxidáns hatásában megnyilvánuló genetikai variabilitás jellemzése. Budapest. Akadémiai Doktori Értekezés. http://reald.mtak.hu/622/7/dc_634_12_doktori_mu.pdf

95. HERCBERG S., PREZIOSI P., GALAN P., FAURE H., ARNAUD J., DUPORT N., MALVY D., ROUSSEL A.M., BRIANCON S., FAVIER A. (1999): The SU-VI-MAX study: a primary prevention trial using nutritional doses of antioxidant vitamins and minerals in cardiovascular diseases and cancer. Supplementation on vitamines et Mineraux Antioxydants. Food Chem Toxicol, 37 925-930. p. http://www.ncbi.nlm.nih.gov/pubmed/10541446

96. HEWETT E.W., HAWKINS J.E. (1968): Sprinkler irrigation to protect apricots from frost. New Zeal Agri Res, 11 (4) 927-938. p. DOI:10.1080/00288233.1968.10422426

97. HEWETT E. W. (1976): Seasonal variation of cold hardiness in apricots. New Zeal Agri Res, 19: (3): 355-358. p. doi: 10.1080/00288233.1976.10429078

98. HITKA G. (2011): Kajszi szabályozott légterü tárolástechnológiájának fejlesztése. Budapest. Doktori értekezés. http://phd.lib.uni-corvinus.hu/564/1/Hitka_Geza.pdf

99. HOFFMANN B. (2011): Télállóság és fagytürés. In: HOFFMANN B. (Szerk.): Növénygenetika. Digitális tankönyvtár. Debreceni Egyetem. http://www.tankonyvtar.hu/hu/tartalom/tamop425/0010_1A_Book_03_Novenygenetika/ch01s 02.html

100.HORMAZA J.I., YAMANE H., RODRIGO J. (2007): Apricot. 173-189. p. In: KOLE, C. (Szerk.): Genome Mapping \& Molecular Breeding. Berlin, New York, Tokyo: Springer, Heidelberg.

101.HORVÁTH D. (2003): A kajszi feldolgozása, tartósítása. 371-378. p. In: Pénzes B., Szalay L. (Szerk.): Kajszi. Budapest: Mezőgazda Kiadó. 400. p.

102.HOWELL G.S., WEISER C.J. (1970): The environmental control of cold acclimation in apple. Plant Physiol, 45 (4) 390-394. p. http://dx.doi.org/10.1104/pp.45.4.390

103.ILJA A.C.W., VAN DE PUTTE B., HOLLMAN P.C.H. (2000): Catechin contents of foods commonly consumed in the Netherlands. 1. Fruits, vegetables, staple foods and processed food. $J$ Agric Food Chem, 48 (5) 1746-1751. p. http://pubs.acs.org/doi/abs/10.1021/jf000025h

104.JANDA T., MAJLÁTH I., SZALAI G. (2014): Interaction of temperature and light in the development of freezing tolerance in plants. J Plant Growth Regul, 33 (2) 460-469. p. http://link.springer.com/article/10.1007/s00344-013-9381-1

105.JIMÉNEZ A.M., MARTÍNEZ-TOMÉ M., EGA I., ROMOJARO F., MURCIA M.A. (2008): Effect of industrial processing and storage on antioxidant activity of apricot 
(Prunus armeniaca v. bulida). Eur Food Res Technol, 227 (1) 125-134. p. doi: 10.1007/s00217-007-0701-1

106.JULIAN C., HERRERO M., RODRIGO J. (2009): Pollen development and chilling requirements in apricot cultivars. Acta Hortic, 814 417-419. p. DOI: 10.17660/ActaHortic.2009.814.69

107.JULIAN C., HERRERO M., RODRIGO J. (2010): Flower bud differentiation and development in fruiting and non-fruiting shoots in relation to fruit set in apricot (Prunus armeniaca L.). Trees, 24 (5) 833-841. p. doi:10.1007/s00468-010-0453-6

108.JULIAN C., RODRIGO J., HERRERO M. (2011): Stamen development and winter dormancy in apricot (Prunus armeniaca). Ann Bot, 108 (4) 617-625. p. http://aob.oxfordjournals.org/content/108/4/617.full.pdf

109.KANG K.S., MOTOSUGI H., YONEMORI K., SUGIURA A. (1998): Supercooling characteristics of some deciduous fruit trees as related to water movement within the bud. J Hortic Sci Biotech, 73 (2) 165-172. p. doi: 10.1080/14620316.1998.11510960

110. KATAYAMA T., NAKAYAMA T.O.M., LEE T.H., CHICHESTER C.O. (1971): Carotenoid transformation in ripening apricots and peaches. J Food Sci, 36 (5): 804-806. p. DOI: 10.1111/j.1365-2621.1971.tb03311.x

111.KRAMER A, TWIGG B.A. (1966): Fundamentals of quality control for the food industry. Westport: Avi Publishing. 512. p.

112.KISS Á. (1992): Az ezerjó hazájában. A móri történelmi borvidék monográfiája. Székesfehérvár: Albawiss Kiadó. 279. p.

113.KOSTINA K.F. (1964): Application the phytogeographical method to apricot classification. Proceedings (Trudi) of the Nikita Botanical Garden. Kolos, Moscow, v.24. 170-189. p.

114.KOSTINA K.F. (1977): Apricot breeding under conditions of USSR south. Acta Hortic, 85 190-194. p. http://dx.doi.org/10.17660/ActaHortic.1981.85.42

115.KRIŠKA B., VACHU゚N Z., NEČAS T. (2005): The apricot breeding programme focused for Sharka resistance. Cerzetari in Pomicultura, Realizari Probleme si Perspective. 329335. p. http://tilia.zf.mendelu.cz/ustavy/551/ustav_551/moldavsko_05.pdf

116.KOVÁCS E., MERÉSZ P., KRISTÓF Z., NÉMETH-SZERDAHELYI E. (2008): Ripening and microstructure of apricot (Prunus armeniaca L.). Acta Aliment Hung, 37 (1) 23-39. p. http://www.akademiai.com/doi/abs/10.1556/AAlim.37.2008.1.3

117. KURZ C., CARLE R., SCHIEBER A. (2008): HPLC-DAD-MSn characterisation of carotenoids from apricots and pumkins for the evaluation of fruit product authenticity. Food Chem, 110 (2) 522-530. p. doi:10.1016/j.foodchem.2008.02.022 
118.LAMP B.M., CONNELL J.H., DUNCAN R.A., VIVEROS M., POLITO V.S. (2001): Almond flower development: floral initation and organogenesis. J Amer Soc Hort Sci, 126 (6) 689-696. p. http://www.plantsciences.ucdavis.edu/polito/jashs126.pdf

119.LANG G.A. (1987): Dormancy: A new universal terminology. HortScience, 22 (5) 817820. p.

120.LAYNE R.E.C. (1978): 'Harcot' apricot. HortScience, 13 64-65. p.

121.LAYNE R.E.C. (1979): 'Harogem' apricot. HortScience, 16 97-98. p.

122.LAYNE R.E.C. (1981): 'Harlayne' apricot. HortScience, 14 758-759. p.

123.LAYNE R.E.C., GADSBY M.F. (1995): Determination of cold hardiness and estimation of potential breeding value of apricot germplasm. Fruit Varieties $J, 49$ (4) 242-248. p.

124.LAYNE R.E.C., BAILEY C.H., HOUGH L.F. (1996): Apricots. 79-111. p. .In: JANICK J., MOORE J.N. (Szerk.): Fruit Breeding: Tree and Tropical Fruits. New York: John Wiley and Sons Inc. 632. p.

125.LAYNE R.E.C. (1996): Genetic improvement of peach, nectarine and apricot cultivars and rootstocks for Canada. Acta Hortic, 374 91-98. p. http://dx.doi.org/10.17660/ActaHortic.1996.374.11

126.LAYNE R.E.C., HUNTER D.M. (2003a): 'AC Harojoy' apricot. HortScience, 38 (1) 138-139. p. http://hortsci.ashspublications.org/content/38/1/138.full.pdf+html

127.LAYNE R.E.C., HUNTER D.M. (2003b): 'AC Haroblush' apricot. HortScience, 38 (1) 142-143. p. http://hortsci.ashspublications.org/content/38/1/142.full.pdf+html

128.LAYNE R.E.C., HUNTER D.M. (2003c): 'AC Harostar' apricot. HortScience, 38 (1) 140-141. p. http://hortsci.ashspublications.org/content/38/1/140.full.pdf+html

129.LECCESE A., BARTOLINI S., VITI R. (2008): Total antioxidant capacity and phenolics content in fresh apricots. Acta Aliment Hung, 37 (1) 65-76 p. http://www.akademiai.com/doi/abs/10.1556/AAlim.37.2008.1.6

130.LECCESE A., BUREAU S., REICH M., RENARD M.G.C.C., AUDERGON J.M., MENNONE C., BARTOLINI S., VITI R. (2010): Pomological and nutraceutical properties in apricot fruit cultivation systems and cold storage fruit management. Plant Foods Hum Nutr, 65 (2) 112-120. p. doi: 10.1007/s11130-010-0158-4.

131.LEDBETTER C., PETERSON S., JENNER J. (2006): Modification of sugar profiles in California adapted apricots (Prunus armeniaca L.) through breeding with Central Asian germplasm. Euphytica, 148 (3) 251-259. p. DOI: 10.1007/s10681-005-9016-0

132.LIFEN Z., FUSHENG C., HONGSHUN Y., HUI L., XIANGZHE G., CHONGBIN J. (2009): Changes in firmness, pectin content and nanostructure of two crisp peach 
cultivars after storage. Food Sci Technol-LEB, 43 (1) 26-32. p. doi:10.1016/j.Iwt.2009.06.015

133. LINDÉN L., RITA H., SUOJALA T. (1996): Logit models for estimating lethal temperatures in apple. HortScience, 31 (1) 91-93. p. http://hortsci.ashspublications.org/content/31/1/91.full.pdf

134.LINDÉN L., PALONEN P. (2000): Relating freeze-induced electrolyte leakage measurements to lethal temperature in red raspberry. J Amer Soc Hort Sci, 125 (4) 429435. p. http://journal.ashspublications.org/content/125/4/429.abstract

135. LINDÉN L. (2002): Measuring cold hardiness in woody plants. Academic Dissertation. Finland. http://ethesis.helsinki.fi/julkaisut/maa/sbiol/vk/linden/measurin.pdf

136.LINDOW S.E., ARNY D.C., UPPER C.D. (1982): Bacterial ice nucleation: A factor in frost injury to plants. Plant Physiol, 70 (4): 1084-1089. p. http://www.ncbi.nlm.nih.gov/pmc/articles/PMC1065830/

137.LUCKWILL L. C. (1970): Progress in the control of flowering and fruiting. Proc. $18^{\text {th }}$ Intern. Hort. Congr. (Tel Aviv). 4 177-185. p.

138.LUGASI A. (2000): Az élelmiszer eredetű flavonoidok potenciális egészségvédő hatása. Orvosi Hetilap, $141 \quad$ (32) 1751-1760. p. $\quad$ http://www.ikaresz.hu/sites/default/files/mellekletek/az_elelmiszer_eredetu_flavonoidok_potencialis_egesz segvedo_hatasa.pdf

139.MADRAU M.A., PISCOPO A., SANGUINETTI A.M., DEL CARO A., POIANA M., ROMEO F.V., PIGA A. (2009): Effect of drying temperature on polyphenolic content and antioxidant activity of apricots. Eur Food Res Technol, 228 (3): 441-448. p. doi:10.1007/s00217-008-0951-6

140.MANGANARIS A.G., MAINOU A., GOUDARAS A., LEDBETTER C. (1999): Identification of plum $\mathrm{x}$ apricot interspecific hybrids using isoenzyme polymorphism. Acta Hortic, 488 361-368. p. http://dx.doi.org/10.17660/ActaHortic.1999.488.57

141.MARTÍNEZ-CALVO J., LLÁCER G., BADENES M.L. (2012): 'Moixent' an apricot resistant to sharka. HortScience, 47 (9) 1367-1368. p. http://hortsci.ashspublications.org/content/46/4/655.full

142.MÁDY R., SZALAY L. (2003): Kajszifajták. 85-126. p. In: PÉNZES B., SZALAY L. (Szerk.): Kajszi. Budapest: Mezőgazda Kiadó. 400. p.

143.MEHLENBACHER S.A., COCIU V., HOUGH L.F. (1990): Apricots (Prunus). Acta Hortic, 290 65-107. p. http://dx.doi.org/10.17660/ActaHortic.1991.290.3 
144.MEHLENBACHER S.A., COCIU V., HOUGH L.F. (1991): Apricots (Prunus). 63-108. p. In: MOORE J.N., BALLINGTON J.R.JR. (Szerk.): Genetic resources of temperature fruit and nut crops. Wageningen. ISHS. $980 \mathrm{p}$.

145.MENG Q, R; LIANG Y. Q., WANG W.F., DU S.H., LI Y.H., YANG J. M. (2007): Study on supercooling point and freezing point in floral organs of apricot. Agricultural Science in China, 6 (11) 1330-1335. p. doi:10.1016/S1671-2927(07)60180-1

146.MGSZH. (2011): A Mezőgazdasági Szakigazgatási Hivatal központi közleménye. http://2010-

2014.kormany.hu/download/a/89/30000/hatalapsz\%C5\%911\%C5\%91gy\%C3\%BCm2011 $\mathrm{m} \% \mathrm{C} 3 \% \mathrm{~A} 1 \mathrm{jus} 1 . \mathrm{pdf}$

147.MIRANDA C., SANTESTEBAN L.G., ROYO J.B. (2005): Variability in the relationship between frost temperature and injury level for some cultivated prunus species. HortScience, $40 \quad$ (2) $\quad 457-361 . \quad$ p. http://hortsci.ashspublications.org/content/40/2/357.full.pdf

148.MOLISH H. (1926): Növényélettan, mint a kertészet elmélete. Budapest: Királyi Magyar Természettudumányi Társulat. 365. p.

149.MOLNÁR L. (1992): Kényszernyugalom vagy fejlődés? Kertészet és Szőlészet, 41 (7) 7. p.

150.MOREAU-RIO M, ROTY C. (1998): L'abricot: Perceptions et attentes des consommateurs français. Ctifl-Infos, 141 16-21.p.

151.MORIKIAN E.S. (1983): Apricots of Armenia: origin and classification of varieties. Acta Hortic, 121 271-274. p. 10.17660/ActaHortic.1983.121.36

152.MOUSAVI S., ALISOLTANI A., SHIRAN B., FALLAHI H., EBRAHIMIE E., IMANI A., HOUSHMAND S. (2014): De novo transcriptome assembly and comparative analysis of differentially expressed genes in Prunus dulcis Mill. in response to freezing stress. PLoS One, 9 (8) e104541. doi: 10.1371/journal.pone.0104541

153.MRATINÍC E., POPOVSKI B., MILOŠEVIC T., POPOVSK, M. (2011): Evaluation of apricot fruit quality and correlations between physical and chemical attributes. Czech $J$ Food Sci, 29 161-170. p. doi: 10.1371/journal.pone.0104541

154.MSZ EN 12147:1998 Gyümölcs- és zöldséglevek. A titrálható savasság meghatározása.

155.NACZK M., SHAHIDI F. (2004): Extraction and analysis of phenolics in food. $J$ Chromatogr A, 1054 (1-2) 95-111. p. doi:10.1016/j.chroma.2004.08.059

156.NÉBIH (2014): Szőlő-és Gyümölcsfajták Nemzeti Fajtajegyzék. Budapest. https://www.nebih.gov.hu/szakteruletek/szakteruletek/novterm_ig/szakteruletek/fajta_sza p/jegyzekek/nemzeti.html 
157.NÉMETH SZ., REMÉNYI M.L., SZALAY L. (2009): Development of apricot flower buds on different types of fruiting branches. Acta Horticulturae et Regiotecturae, 12 8991. p.

158.NÉMETH SZ., HAJNAL V., SZALAY L., VÉGVÁRI GY. (2011a): Négy magyar kajszifajta beltartalmi értékeinek összehasonlítása. Kertgazdaság, 43 (1) 19-22. p. http://www.uni-

corvinus.hu/fileadmin/user_upload/hu/kerteszettudomanyi_kar/kertgazdasag/files/2011_0 1/2011_01_Gyumolcstermesztes1.pdf

159.NEMETH SZ., SZALAY L., FICZEK G., STEGER-MATE M., SANDOR G., VEGVARI GY., TOTH M. (2011b): Analysis of chemical parameters determining the fruit quality of apricot cultivars during ripening. Acta Aliment Hung, 40 (Suppl.), 109119. p. http://dx.doi.org/10.1556/AAlim.40.2011.Suppl.11

160.NÉMETH SZ. (2012): A virágrügy-és a gyümölcsfejlődés fenológiai, morfológiai és biokémiai jellemzése fontosabb kajszifajták esetében. Budapest. Doktori értekezés.

161.NERI D., MORINI F., MASSETARI F., PIRAZZINE P. (2010): Pruning: how to manage shoot growth. Acta Hortic, 862 358-363. p. doi:10.17660/ActaHortic.2010.862.55

162.NITRANSKI S. (1977): Growth and fruiting of apricot cultivar Rakovsky on different rootstocks. Pol'nohospodarstvo, 23 (10) 884-894. p.

163.NUZZO V., BIASI R., DICHIO B., MONTANARO G., XILOYANNIS C, LANZIERI A. (1999): Influence of different seasonal light availability on flower bud quality in cv Tirinthos (Prunus armeniaca L.). Acta Hortic, 488 477-482. p. 10.17660/ActaHortic.1999.488.76

164.NYÉKI J. (2003): Virágzás és termékenyülés. 158-200. p. In: PAPP J. (Szerk.): Gyümölcstermesztési alapismeretek. Budapest: Mezőgazda Kiadó, 472. p.

165.NYUJTÓ F., BANAI B.-NÉ. (1975): Előzetes közlemény a kajszibarack fajták termőrügyeinek téli morfogenézisének vizsgálatáról. Gyümölcstermesztés, 2 15-20. p.

166.NYUJTÓ F. (1980): A kajszibarack. 248-266. p. In: NYÉKI J. (Szerk.): Gyümölcsfajták virágzásbiológiája és termékenyülése. Budapest: Mezőgazdasági Kiadó, 320. p.

167.NYUJTÓ F., SURÁNYI D. (1981): A kajszibarack kultúrtörténete. 45-48. p. In: NYUJTÓ F., SURÁNYI D. (Szerk.): Kajszibarack. Budapest: Mezőgazdasági Kiadó, 467. p.

168.PAROLARI R., VIRGILI R., BOLZONI L., CARERI M., MANGIA A. (1992): Analysis of sensory and instrumental data of apricot purees with pattern recognition techniques. Analytica Chimica Acta, 259 (2) 257-265. p. doi:10.1016/0003-2670(92)85375-G 
169.PEDERSON C.B., KYLE J., JENKINSON A.M., GARDNER P.T., MCPHAIL D.B., DUTHIE G.G. (2000): Effect of blueberry and cranberry juice consumption on the plasma antioxidant capacity of healthy female volunteers. Eur J Clin Nutr, 54 (5) 405 408. p. http://www.ncbi.nlm.nih.gov/pubmed/10822287

170.PEDRYC A., SZABÓ Z. (1995): Extention of ripening season of apricot due to breeding foreign cultivar introduction in Hungary. Acta Hortic, 348 141-146. p.

171.PEDRYC A., KORBULY J., SZABÓ Z. (1999): Artificial frost treatment methods of stone fruits. Acta Hortic, 488 377-380. p. 10.17660/ActaHortic.1999.488.60

172.PEDRYC A., HERMÁN R. (2011): A sárgabarack nemesítése Magyarországon. 213236. p. In: SURÁNYI D. (Szerk.): A sárgabarack. Gödöllö: Szent István Egyetemi Kiadó, 303. p.

173.PEDRYC A., HERMÁN R. (2012): New apricot cultivars bred at the Corvinus University of Budapest, Hungary. Acta Hortic, 966 205-210. p. DOI: 10.17660/ActaHortic.2012.966.32

174.PETHÖ M. (1996): Mezőgazdasági növények élettana. Budapest: Akadémiai Kiadó, 391395. p.

175.PÉNZES B., SZALAY L. (2003): Kajszi. Budapest: Mezőgazda Kiadó, 400. p.

176.PROEBSTING E.L. (1963): The role of air temperatures and bud development in determining hardiness of dormant Elberta peach fruit buds. P Am Soc Hortic Sci, 83259 269. p.

177.PROEBSTING E.L.JR., MILLS H.H. (1966): A standardized temperature-survival curve for dormant Elberta peach fruits buds. P Am Soc Hortic Sci, 89 85-90. p.

178.PROEBSTING E.L.JR. (1970): Relation of fall and winter temperatures to flower bud behaviour and wood hardiness of deciduous fruit trees. HortScience, 5 422-424. p.

179.PROBSTING E.L.JR., MILLS H.H. (1978): A synoptic analysis of peach and cherry flower bud hardiness. J Am Soc Hortic Sci, 103 (6) 842-845. p.

180.PROEBSTING E. L., SAKAI A. (1979): Determining T50 of peach flower buds with exotherm analysis. HortScience, 14 (3) 597-598. p.

181.QUAMME H.A. (1974): An exotermic process involved in the freezing injury to flower buds of several Prunus species. J Am Soc Hortic Sci, 99 (4) 315-318. p.

182.RADI M., MAHROUZ M., JAOUD A., TACCHINI M., AUBERT S., HUGUES M., AMIOT M.J. (1997): Phenolic composition, browning susceptibility and carotenoid content of several apricot cultivars at maturity. HortScience, 32 1087-1091. p. http://hortsci.ashspublications.org/content/32/6/1087.full.pdf 
183.RANDO R.R. (1990): The chemistry of vitamin A and vision. Angew Chem Int Edit, 29 (5): 461-480. p. doi:10.1002/anie.199004611

184.RECORD I.R., DREOSTI I.E., MCINERNEY J.K. (2001): Changes in plasma antioxidant status following consumption of diets high or low in fruit and vegetables or following dietary supplementation with an antioxidant mixture. Br J Nutr, 85 (4) 459464. p. http://www.ncbi.nlm.nih.gov/pubmed/11348560

185.ROUSSOS P.A., SEFFEROU V., DENAXA N.K., TSANTILI E., STATHIS V. (2011): Apricot (Prunus armeniaca L.) fruit quality attributes and phytochemicals under different crop load. Sci Hortic-Amsterdam, 129 (3): 472-478. p. doi:10.1016/j.scienta.2011.04.021

186.ROWE P.M. (1996): Beta-carotene takes a collective beating. The Lancet, 347 249. p.

187.RUIZ D., EGEA J., TOMÁS-BARBERAN F.A., GIL M.I. (2005a): Carotenoids from new apricot (Prunus armeniaca L.) varieties and their relationship with flesh and skin color. J Agr Food Chem, 53 (16) 6368-6374. p. http://pubs.acs.org/doi/abs/10.1021/jf0480703

188.RUIZ D., EGEA J., GIL M.I., TOMÁS-BARBERÁN F.A. (2005b): Characterization and quantitation of phenolic compounds in new apricot (Prunus armeniaca L.) varieties. $J$. Agr Food Chem, 53 (24) 9544-9552. p. http://www.ncbi.nlm.nih.gov/pubmed/16302775

189.RUIZ D., EGEA J., GIL M.I., TOMÁS-BARBERAN F.A. (2006): Phytonutrient content in new apricot (Prunus armeniaca L.) varieties. Acta Hortic, 717 363-365. p. doi:10.17660/ActaHortic.2006.717.73

190. RUIZ D., EGEA J. (2008): Phenotypic diversity and relationships of fruit quality traits in apricot (Prunus armeniaca L.) germplasm. Euphytica, 163 (1) 143-158. p. doi:10.1007/s10681-007-9640-y

191.SALAZAR-GUTIÉRREZ M.R., CHAVES B., ANOTHAI J., WHITING M., HOOGENBOOM G. (2014): Variation in cold hardiness of sweet cherry flower buds through different phenological stages. Sci Hortic-Amsterdam, 172 161-167. p. doi:10.1016/j.scienta.2014.04.002

192.SASS-KISS A., KISS J., MILOTARY P., KEREK M.M., TOTH-MARKUS M. (2005): Differences in anthocyanin and carotenoid content of fruits and vegetables. Food Res Int, 38 (8-9) 1023-1029. p. doi:10.1016/j.foodres.2005.03.014

193.SCALABRELLI G., VITI R., CINELLI F. (1991): Change in catalase activity and dormancy of apricot vuds in response to chilling. Acta Hortic, 293 267-274. p. doi: 10.17660/ActaHortic.1991.293.31 
194.SCAlZO J., POLITI A., PELlEGRIRI N., MEZZETTI B., BATTINO M. (2005): Plant genotype affects total antioxidant capacity and phenolic contents in fruit. Nutrition, 21 (2) 207-213. p. doi:10.1016/j.nut.2004.03.025

195.SEELEY S. (1990): Dormancy of apricot buds and seeds. Gartenbauwissenschaft, 55 (6) 1369-1376. p.

196. SHARMA R., GUPTA A., ABROL G.S., JOSHI V.K. (2012): Value addition of wild apricot fruits grown in North-West Himalayan regions - a review. J Food Sci Tech, 51 (11) 2917-2924. p. doi:10.1007/s13197-012-0766-0

197.SHIN H., OH Y., KIM D. (2014): Differences in cold hardiness, carbohydrates, dehydrins and related gene expressions under an experimental deacclimation and reacclimation in Prunus persica. Physiol Plant, 154 (4) 485-499. p. DOI: 10.1111/ppl.12293

198.SHIVANNA, K.R., JOHRI, B.M. (1985): The angiosperm pollen. New Delhi: Wiley Eastern Limited. 5-52. p.

199.SIES H. (1993): Strategies of antioxidant defense. Eur J Biochem, 215 (2) 213-219. p. http://www.ncbi.nlm.nih.gov/pubmed/7688300

200.SINGLETON V.L., ROSSI J.A. (1965): Colorimetry of total phenolic with phosphomolybdic-phosphotungstic acid reagents. Am J Enol Viticult, 16 (3) 144-158. p. http://garfield.library.upenn.edu/classics1985/A1985AUG6900001.pdf

201.SKIBSTED, L.H. (2012): Carotenoids in antioxidant networks, colorants or radical scavengers. J Agr Food Chem, 60 (10) 2409-2417. p. DOI: 10.1021/jf2051416

202.SLUIS V. D.,.A.A., DEKKER M., DE JAGER A., JONGEN W.M.I. (2001): Activity and concentration of polyphenolic antioxidant in apple: effect of cultivar, harvest year, and storage conditions. J Agr. Food Chem, 49 (8) 3606-3613. p. http://pubs.acs.org/doi/abs/10.1021/jf001493u

203.SMEETON R. (1964): Late spring frost damage to apple shoots in the nursery. The East Malling Researche Station, 47 7-74. p.

204.SMITH M.W., CARROLL B.L., TAYLOR G.G. (1994): Cold injury of peach and nectarine cultivars after a fall freeze. HortScience, 29 (7) 821. p. http:/hortsci.ashspublications.org/content/29/7/821.full.pdf

205.SOLTÉSZ M. (1997): Integrált gyümölcstermesztés. Budapest: Mezőgazda Kiadó, 843. p.

206.SOUCI S. W., FACHMANN W., KRAUT H. (1989): Food composition and nutrition tables. Stuttgart: Wissenschaffliche Verlagsgesellschaft Gmb. 1027 p.

207.SOUCI S.W., FACHMANN W., KRAUT H. (2008): Food composition and nutrition tables. 7th ed. Stuttgart: Medpharm Scientific Publication. 1029-1032. p. 
208.SOUTHWICK S. M., FRITTS JR. R. (1995): Commercial chemical thinning of stone fruit in California by gibberellins to reduce flowering. Acta Hortic, 394 135-147. p. 10.17660/ActaHortic.1995.394.13

209.SOUTHWICK S.M., GLOZER K. (2000): Reducing flowering with gibberellins to increase fruit size in stone fruit trees. Applications and implications in fruit production. $\begin{array}{llllll}\text { Horttechnology, } & 10 & \text { (4) } & 744- & 751 . & \text { p. }\end{array}$ http://horttech.ashspublications.org/content/10/4/744.full.pdf

210.ŠTAMPAR F., USENIK V., DOLENC-ŠTURM K. (1999): Evaluating of some quality parameters of different apricot cultivars using hplc method. Acta Aliment Hung, 28 (4) 297-309. p. http://dx.doi.org/10.1556/AAlim.28.1999.4.1

211.STÉGER-MÁTÉ M., FICZEK G., KÁLLAY E., BUJDOSÓ G., BARTA J., TÓTH M. (2010): Optimising harvest time of sour cherry cultivars on the basis of quality parameters. Acta Aliment Hung, 39 (1) 67-73. p. DOI:10.1556/Aalim.39.2010.1.6.

212.STOW J. (1995): Quality measurements of apples. Postharvest News and Information, 6 32-33. p.

213.STUSHNOFF C. (1972) Breeding and selection methods for cold hardiness in deciduous fruit crops. HortScience, 7 10-13. p.

214.SURÁNYI D. (1981): A kajszibarack rendszertana és a fajok botanikai jellemzése. 32-44. p. In: NYUJTÓ F., SURÁNYI D. (Szerk.): Kajszibarack. Budapest: Mezőgazdasági Kiadó, 467. p.

215.SURÁNYI D., MOLNÁR L. (1981): A kajszibarack élettana. 177-227. p In: NYUJTÓ F., SURÁNYI D. (Szerk.): Kajszibarack. Budapest: Mezőgazdasági Kiadó, 467. p.

216.SURÁNYI D. (2003): A kajszi jelentősége, termesztésének története és helyzete. 11-29. p. In: PÉNZES B., SZALAY L. (Szerk.): Kajszi. Budapest: Mezőgazda Kiadó, 400. p.

217.SURÁNYI D. (2011): A sárgabarck. Gödöllő: Szent István Egyetemi Kiadó, 303. p.

218.SURÁNYI D., MOLNÁR L. (2011): A fajták téli és tavaszi fagytürése. In: SURÁNYI D. (Szerk.): A sárgabarack. Gödöllő: Szent István Egyetemi Kiadó, 303. p.

219.SURÁNYI D., SZALAY L. (2011): A termésnövekedést és a gyümölcs nagyságát befolyásoló tényezők. In: SURÁNYI D. (Szerk.): A sárgabarack. Gödöllő: Szent István Egyetemi Kiadó, 303. p.

220.SZABÓ Z., NYÉKI J. (1988): Kajszi-, cseresznye és meggyfajták fagykárosodása. Gyümölcs-Inform, 10 (1) 15-19. p.

221.SZABÓ Z., SOLTÉSZ M., BUBÁN T., NYÉKI J. (1995): Low winter temperature injury to apricot flower buds in Hungary. Acta Hortic, 384 273-276. p. doi:10.17660/ActaHortic.1995.384.41 
222.SZABÓ Z., NYÉKI J., SOLTÉSZ M. (2002): Kajszi. 246-257. p. In: Nyéki J., Soltész M., Szabó Z. (Szerk.): Fajtatársitás a gyümölcsültetvényekben. Budapest: Mezőgazda Kiadó, 382. p.

223.SZABÓ Z., NYÉKI J., SOLTÉSZ M. (2003): Apricot. 411-423. p. In: KOZMA P., NYÉKI J., SOLTÉSZ M., SZABÓ Z. (Szerk.): Floral biology, pollination and fertilisation in temperate zone fruit species and grape. Budapest: Akadémiai Kiadó, 621. p.

224.SZALAI I. (1994): A növények élete I.-II. Szeged: JATEPress, 1103. p.

225.SZALAY L., PEDRYC A., SZABÓ Z. (1999): Dormancy and cold hardiness of flower buds of some Hungarian apricot varieties. Acta Hortic, 488 315-319. p. 10.17660/Acta Hortic.1999.488.49.

226.SZALAY L. (2001): Kajszi-és őszibarackfajták fagy-és téltürése. PhD értekezés. Budapest, Szent István Egyetem.

227.SZALAY L., BALLA CS. (2003): Szüret, szüret utáni müveletek. 338-367. p. In: PÉNZES B., SZALAY L. (Szerk.): Kajszi. Budapest, Mezőgazda Kiadó, 400. p.

228.SZALAY L. (2003): A virágrügyek kialakulása és fejlődése. 162-167. p. In: PÉNZES B., SZALAY L. (Szerk.): Kajszi. Budapest: Mezőgazda Kiadó, 400. p.

229.SZALAY L., BALÁZS G., NAGY P. (2004): Evaluation of foreign apricot cultivars in Hungary. International Journal of Horticultural Science, 10 (3) 51-55. p.

230.SZALAY L. (2004): Kajszi. 209-232. p. In: PAPP J. (Szerk.): A gyümölcsök termesztése. Budapest, Mezőgazda Kiadó, 554. p.

231.SZALAY L., PAPP J., PEDRYC A., SZABÓ Z. (2006a): Diversity of apricot varieties based on traits determining winter hardiness and early spring frost tolerance of floral buds. Acta Hortic, 701 131-134. p. DOI: 10.17660/ActaHortic.2006.701.17

232.SZALAY L., PEDRYC A., SZABÓ Z., PAPP J. (2006b): Influence of the changing climate on flower bud development of apricot varieties. Acta Hortic, 717 75-78. p. 10.17660/ActaHortic.2006.717.12

233.SZALAY L., TIMON B., NÉMETH SZ., PAPP J., TÓTH M. (2010): Hardening and dehardening of peach flower buds. HortScience, 45 (5) 761-765. p. http:/hortsci.ashspublications.org/content/45/5/761.full.pdf

234.SZALAY L. (2008): Development and cold hardiness of flower buds of stone fruits. 6382 p. In: NYÉKI J., SOLTÉSZ M., SZABÓ Z. (Szerk.): Morphology, biology and fertility of flowers in temperate zone fruits. Budapest: Academic Press, 447. p.

235.SZALAY L. (2009): Kajszi. 127-136. p. In: TÓTH M. (Szerk.): Gyümölcsfaj- és fajtaismeret. Budapest: Inkart Kft., 234. p. 
236.SZALAY L., NÉMETH S. (2010): Phenological process of dormancy in apricot genotypes in the central part of the Carpatian Basin. Acta Hortic, 862 251-255. p. 10.17660/ActaHortic.2010.862.39

237.SZALAY L. (2013): A kajszi hazai és külföldi nemesítésének főbb szempontjai és eredményei; Hazai és külföldi fajtaújdonságok. In: ZÁMBORINÉ N.É., HORVÁTH L.(Szerk.): Korszerü Kertészet, digitális tankönyv kertészmérnök MSc hallgatók számára. Budapesti Corvinus Egyetem Kertészettudományi Kar. (ISBN: 978-963-503-537-3) http://kertesztananyag.hu/gyumolcsfajta-ertekeles/kajszi

238.TAIZ L., ZEIGER E. (2010): Stress Physiology. 591-623. p. In: TAIZ L., ZEIGER E. (Szerk.): Plant Physiology. 781. p.

239.TOMCSÁNYI P. (1959): Fajtaismeret-A kajszibarack fajták rendszerezése. 44-46. p. In: NYUJTÓ F., TOMCSÁNYI P. (Szerk.): A kajszibarack és termesztése. Budapest: Mezőgazdasági Kiadó, 330. p.

240.TRIPOLI E., GUARDIA M., GIAMMANCO S., MAJO D., GIAMMANCO M. (2007): Citrus flavonoids: Molecular structure, biological activity and nutritional properties: A rewiew. Food Chem, 104 (2) 466-479. p. doi:10.1016/j.foodchem.2006.11.054

241.TROMP J. (2005): Frost and plant hardiness. 74-83. p. In: TROMP J., WEBSTER A.D., WERTHEIM S.J. (Szerk.): Fundamentals of Temperate Zone Tree Fruit Production. Leiden: Backhuys Publishers, 400. p.

242.VALENTINI N., MELLANO M.G., ANTONIONI I., BOTTA R. (2006): Chemical, physical and sensory analysis for evaluating quality of apricot cultivars. Acta Hortic, 701 559-564. p. 10.17660/ActaHortic.2006.701.97

243.VAVILOV N.I. (1926): Studies on the origin of cultivated plants. Bulletin of Applied Botany and Plant Breeding, 14 1-245. p.

244.VOSS D. H. (1992): Relating colorimeter measurement of plant colour to the Royal Horticultural Society Colour. HortScience, 27 (12) 1256-1260. p. http://hortsci.ashspublications.org/content/27/12/1256.full.pdf

245.WANI S.M., NURSAT J., WANI T.A., MUKHTAR A., MASOODI F.A., GANI A. (2015): Optimization of antioxidant activity and total polyphenols of dried apricot fruit extracts (Prunus armeniaca L.) using response surface methodology. Journal of the Saudi Society of Agricultural Sciences. in press doi:10.1016/j.jssas.2015.03.006

246.VASZILY B. (2012): Intenzív cseresznye művelési rendszerek hatása a fajták vegetatívés generatív teljesítményére. Doktori értekezés. Debrecen.

247.WERNER C.M., CRASSWELLER R.M., CLARK T.E. (1993): Cold hardiness of peach stem tissue over two dormant seasons. J Amer Pomolog Soc, 47 (2) 72-79. p. 
248.WESTWOOD M.N. (1993): Temperate-zone pomology. Portland, Oregon, USA: Timber Press, 417 p.

249.WISNIEWSKI M., NORELLI J., BASSETT C., ARTLIP T., MACARISIN D. (2011): Ectopic expression of a novel peach (Prunus persica) CBF transcription factor in apple (Malus $\times$ domestica) results in short-day induced dormancy and increased cold hardiness. Planta, 233 (5) 971-983. p. doi: 10.1007/s00425-011-1358-3.

250.VITI R., MONTELEONE P. (1991): Observations on flower bud growth in some low yield varieties of apricot.Acta Hortic, 293 319-326. p. doi:10.17660/ActaHortic.1991.293.37 251.XILOYANNIS C., CELANO G., DICHIO B., NUZZO V. (1999): Orchard management. Acta Hortic, 488 457-464. p. doi:10.17660/ActaHortic.1999.488.73

252.YAO S. (2011): Preliminary and Regional Reports. Winter 2011 low-temperature injury to stone fruit flower buds in New Mexico. Horttechnology, 21 (6) 767-772. p. http://aces.nmsu.edu/ces/plant_sciences/documents/stone-fruit-flower-buds-winterdamage-2011-horttech-21-767-772.pdf

253.YUAN Z., CHEN X., HE T., PENG J., FENG T., ZHANG C. (2007): Population genetic structure in apricot (Prunus armeniaca L.) cultivars revealed by fluorescent-AFLP markers in Southern Xinjiang, China. Journal of Genetics and Genomics, 34 (11) 10371047. p. doi:10.1016/S1673-8527(07)60117-9

254.ZAGHDOUDI K., PONTVIANNE S., FRAMBOISER X., ACHARD M., KUDAIBERGENOVA R., AYADI-TRABELSI M., KALTHOUM-CHERIF J., VANDERESSE R., FROCHOT C., GUIAVARCH Y. (2015): Accelerated solvent extraction of carotenoids from: Tunisian Kaki (Dyospyros kaki L.), peach (Prunus persica L.) and apricot (Prunus armeniaca L.). Food Chem, 184:131-139. doi:10.1016/j.foodchem.2015.03.072

255.ZAYAN A.Z. (1981): Különböző kajszibarack fajták hidegtürésének alakulása szénhidrát, fehérje és az aminósavtartalom függvényében. Budapest. Kandidátusi értekezés.

256.ZHU G.H., LIU Z.Q. (1987): Determination of median lethal temperature using logistic function. 291-298. p. In: P.H.LI (Szerk.): Plant cold hardiness. New York: Academic Press. 694. p. 


\section{M2. Táblázatok}

M.2.1. táblázat: A virágrügyek klímakamrás fagytürési vizsgálatainak mintavételi időpontjai és kezelési hőmérsékletei 2010/11 telén

\begin{tabular}{cccc}
\hline $\begin{array}{c}\text { a standard fajták } \\
\text { mintavételi időpontjai }\end{array}$ & $\begin{array}{c}\text { kezelési } \\
\text { hőmérsékletek } \\
\left({ }^{\circ} \mathbf{C}\right)\end{array}$ & $\begin{array}{c}\text { az új fajták } \\
\text { mintavételi } \\
\text { időpontjai }\end{array}$ & $\begin{array}{c}\text { kezelési } \\
\text { hömérsékletek } \\
\left({ }^{\circ} \mathbf{C}\right)\end{array}$ \\
\hline 2010.09 .01$. & $-7,-9,-11$ & 2010.10 .07$. & $-12,-14,-16,-18$ \\
2010.09 .11$. & $-6,-8,-10,-12,-14$ & 2010.10 .19$. & $-16,-18,-20$ \\
2010.09 .27$. & $-12,-14,-16,-18$ & 2010.11 .18$. & $-17,-19,-21,-23$ \\
2010.10 .20$. & $-17,-18,-20,-22$ & 2010.12 .14$. & $-18,-20,-21$ \\
2010.11 .09$. & $-17,-19,-21,-23$ & 2011.01 .02$. & $-17,-19,-21$ \\
2010.11 .19$. & $-17,-19,-21,-23$ & 2011.01 .13$. & $-15,-17,-19,-21$ \\
2010.12 .15$. & $-18,-20,-22,-24$ & 2011.02 .21$. & $-12,-14,-15,-17$ \\
2011.01 .02$. & $-19,-21,-23,-25$ & & \\
2011.01 .13$. & $-16,-18,-20,-22$ & & \\
2011.01 .27$. & $-15,-17,-19,-21$ & & \\
2011.02 .16$. & $-13,-15,-17,-20$ & & \\
2011.03 .08$. & $-9,-11,-13$ & & \\
2011.03 .21$. & $-7,-8,-9,-10$ & & \\
\hline
\end{tabular}

M.2.2. táblázat: A virágrügyek klímakamrás fagytürési vizsgálatainak mintavételi időpontjai és kezelési hőmérsékletei 2011/12 telén

\begin{tabular}{cccc}
\hline $\begin{array}{c}\text { A standard fajták } \\
\text { mintavételi idópontjai }\end{array}$ & $\begin{array}{c}\text { Kezelési } \\
\text { hőmérsékletek }\left({ }^{\circ} \mathbf{C}\right)\end{array}$ & $\begin{array}{c}\text { Az új fajták } \\
\text { mintavételi időpontjai }\end{array}$ & $\begin{array}{c}\text { Kezelési } \\
\text { hőmérsékletek }\left({ }^{\circ} \mathbf{C}\right)\end{array}$ \\
\hline 2011.09 .01$. & $-5,-7,-9,-11$ & 2011.09 .16$. & $-7,-9,-11,-13$ \\
2011.09 .16$. & $-7,-9,-11,-13$ & 2011.10 .17 & $-14,-16,-18,-20$ \\
2011.10 .04$. & $-9,-11,-13,-15$ & 2011.12 .09$. & $-19,-21,-23,-25$ \\
2011.10 .17$. & $-14,-16,-18,-20$ & 2012.01 .09$. & $-19,-21,-23,-25$ \\
2011.11 .14$. & $-17,-19,-21,-23$ & & \\
2011.12 .09$. & $-19,-21,-23,-25$ & & \\
2011.12 .22$. & $-19,-21,-23,-25$ & & \\
2012.01 .09$. & $-19,-21,-23,-25$ & & \\
2012.02 .07$. & $-15,-17,-19,-21$ & & \\
2012.02 .21$. & $-13,-15,-17,-19$ & & \\
2012.03 .12$. & $-9,-11,-13,-15$ & & \\
\hline
\end{tabular}


M.2.3. táblázat: A virágrügyek klímakamrás fagytürési vizsgálatainak mintavételi időpontjai és kezelési hőmérsékletei 2012/13 telén

\begin{tabular}{cccc}
\hline $\begin{array}{c}\text { a standard fajták } \\
\text { mintavételi időpontjai }\end{array}$ & $\begin{array}{c}\text { kezelési } \\
\text { hőmérsékletek }\left({ }^{\circ} \mathbf{C}\right)\end{array}$ & $\begin{array}{c}\text { az új fajták } \\
\text { mintavételi időpontjai }\end{array}$ & $\begin{array}{c}\text { kezelési } \\
\text { hőmérsékletek }\left({ }^{\circ} \mathbf{C}\right)\end{array}$ \\
\hline 2012.09 .01$. & $-7,-8,-9,-10$ & 2012.10 .16$. & $-12,-14,-16,-18$ \\
2012.09 .14$. & $-9,-10,-11,-12,-13$ & 2012.11 .15$. & $-15,-17,-19,-21$ \\
2012.10 .16$. & $-12,-14,-16,-18$ & 2012.12 .12$. & $-17,-19,-21,-23$ \\
2012.10 .25$. & $-15,-17,-19,-21$ & 2013.01 .22$. & $-15,-17,-19,-21$ \\
2012.11 .15$. & $-15,-17,-19,-21$ & 2013.02 .11$. & $-15,-17,-19,-21$ \\
2012.11 .28$. & $-18,-20,-22$ & & \\
2012.12 .12$. & $-17,-19,-21,-23$ & & \\
2013.01 .01$. & $-19,-21,-23,-25$ & & \\
2013.01 .10$. & $-17,-19,-21,-23$ & & \\
2013.01 .22$. & $-15,-17,-19,-21$ & & \\
2013.02 .11$. & $-15,-17,-19,-21$ & & \\
2013.03 .05$. & $-10,-11,-12,-13$ & & \\
2013.03 .26$. & $-6,-7,-8,-9$ & & \\
\hline
\end{tabular}


M.2.4. táblázat: A standard fajták lineáris regresszióval becsült $\left(\mathrm{LT}_{50}\right)$ értékei a 2010/2011-es évjáratban

\begin{tabular}{|c|c|c|c|c|c|c|}
\hline Fagytürés & $\mathbf{R}^{2}$ & $\mathbf{F}$ & \multicolumn{2}{|c|}{ Együtthatók } & $\mathbf{t}$ & $\mathbf{L T}_{50}$ érték \\
\hline \multicolumn{7}{|c|}{ 2010. szeptember 1.} \\
\hline \multirow[t]{2}{*}{ Ceglédi bíborkajszi } & 0,926 & $201,7 * * *$ & konstans & $-310,3$ & $-12,3 * * *$ & $-8,4$ \\
\hline & & & $\mathrm{x}$ együttható & $-42,4$ & $-14,2 * * *$ & \\
\hline \multirow[t]{2}{*}{ Gönci magyar kajszi } & 0,961 & $395,5 * * *$ & konstans & $-269,7$ & $-17,4 * * *$ & $-9,4$ \\
\hline & & & $\mathrm{x}$ együttható & $-34,1$ & $-19,9 * * *$ & \\
\hline \multirow[t]{2}{*}{ Rózsakajszi C 1406} & 0,965 & $445,9 * * *$ & konstans & $-290,05$ & $-17,7 * * *$ & $-10,1$ \\
\hline & & & $\mathrm{x}$ együttható & $-33,7$ & $-21,1 * * *$ & \\
\hline \multicolumn{7}{|c|}{ 2010. szeptember 11.} \\
\hline \multirow[t]{2}{*}{ Ceglédi bíborkajszi } & 0,943 & $166,9 * * *$ & konstans & $-211,87$ & $-10,16 * * *$ & $-10,7$ \\
\hline & & & $\mathrm{x}$ együttható & $-24,43$ & $-12,92 * * *$ & \\
\hline \multirow[t]{2}{*}{ Gönci magyar kajszi } & 0,932 & $136,06^{* * *}$ & konstans & $-173,163$ & $-9,36 * * *$ & $-11,4$ \\
\hline & & & $\mathrm{x}$ együttható & $-19,533$ & $-11,66^{* * *}$ & \\
\hline \multirow[t]{2}{*}{ Rózsakajszi C 1406} & 0,963 & $410,95 * * *$ & konstans & $-142,11$ & $-15,087 * * *$ & $-12,2$ \\
\hline & & & x együttható & $-15,77$ & $-20,27 * * *$ & \\
\hline \multicolumn{7}{|c|}{ 2010. szeptember 27} \\
\hline \multirow[t]{2}{*}{ Ceglédi bíborkajszi } & 0,957 & $352,44 * * *$ & konstans & $-187,6$ & $-14,96 * * *$ & $-14,2$ \\
\hline & & & $\mathrm{x}$ együttható & $-16,703$ & $-18,8 * * *$ & \\
\hline \multirow[t]{2}{*}{ Gönci magyar kajszi } & 0,913 & $168,2 * * *$ & konstans & $-161,203$ & $-10,45^{* * *}$ & $-14,9$ \\
\hline & & & $\mathrm{x}$ együttható & $-14,2$ & $-12,97 * * *$ & \\
\hline \multirow[t]{2}{*}{ Rózsakajszi C 1406} & 0,895 & $187,033 * * *$ & konstans & $-175,79$ & $-11,51 * * *$ & $-16,3$ \\
\hline & & & $\mathrm{x}$ együttható & $-13,894$ & $-13,68 * * *$ & \\
\hline \multicolumn{7}{|c|}{ 2010. október 20.} \\
\hline \multirow[t]{2}{*}{ Ceglédi bíborkajszi } & 0,872 & $149,75^{* * *}$ & konstans & $-169,01$ & $-9,58 * * *$ & $-18,2$ \\
\hline & & & $\mathrm{x}$ együttható & $-12,03$ & $-12,24 * * *$ & \\
\hline \multirow[t]{2}{*}{ Gönci magyar kajszi } & 0,973 & $353,99 * * *$ & konstans & $-112,52$ & $-12,77 * * *$ & $-19,8$ \\
\hline & & & $\mathrm{x}$ együttható & $-8,21$ & $-18,82 * * *$ & \\
\hline \multirow[t]{2}{*}{ Rózsakajszi C 1406} & 0,931 & $81,15 * * *$ & konstans & $-388,9$ & $-8,53 * * *$ & $-20,7$ \\
\hline & & & $\mathrm{x}$ együttható & $-22,18$ & $-9,01 * * *$ & \\
\hline \multicolumn{7}{|c|}{ 2010. november 9} \\
\hline \multirow[t]{2}{*}{ Ceglédi bíborkajszi } & 0,983 & $917,54 * * *$ & konstans & $-321,99$ & $-25,89 * * *$ & $-18,8$ \\
\hline & & & $\mathrm{x}$ együttható & $-19,76$ & $-30,29 * * *$ & \\
\hline \multirow[t]{2}{*}{ Gönci magyar kajszi } & 0,886 & $77,65 * * *$ & konstans & $-397,92$ & $-7,79 * * *$ & $-19,9$ \\
\hline & & & $\mathrm{x}$ együttható & $-22,45$ & $-8,81 * * *$ & \\
\hline \multirow[t]{2}{*}{ Rózsakajszi C 1406} & 0,96 & $381,73 * * *$ & konstans & $-300,71$ & $-16,69 * * *$ & -21 \\
\hline & & & x együttható & $-16,71$ & $-19,54 * * *$ & \\
\hline
\end{tabular}




\begin{tabular}{|c|c|c|c|c|c|c|}
\hline Fagytürés & $\mathbf{R}^{2}$ & $\mathbf{F}$ & \multicolumn{2}{|c|}{ Együtthatók } & $\mathbf{t}$ & $\mathbf{L T}_{50}$ érték \\
\hline \multicolumn{7}{|c|}{ 2010. november 19} \\
\hline \multirow[t]{2}{*}{ Ceglédi bíborkajszi } & 0,942 & $161,7 * * *$ & konstans & $-467,08$ & $-11,19 * * *$ & $-19,5$ \\
\hline & & & $\mathrm{x}$ együttható & $-26,51$ & $-12,72 * * *$ & \\
\hline \multirow[t]{2}{*}{ Gönci magyar kajszi } & 0,925 & $122,56 * * *$ & konstans & $-412,94$ & $-9,95 * * *$ & $-20,2$ \\
\hline & & & $\mathrm{x}$ együttható & $-22,94$ & $-11,07 * * *$ & \\
\hline \multirow[t]{2}{*}{ Rózsakajszi C 1406} & 0,964 & $427,5 * * *$ & konstans & $-293,56$ & $-17,75 * * *$ & $-21,2$ \\
\hline & & & x együttható & $-16,24$ & $-20,68 * * *$ & \\
\hline \multicolumn{7}{|c|}{ 2010. december 15} \\
\hline \multirow[t]{2}{*}{ Ceglédi bíborkajszi } & 0,939 & $245,1 * * *$ & konstans & $-313,62$ & $-13,57 * * *$ & $-20,2$ \\
\hline & & & $\mathrm{x}$ együttható & $-18,04$ & $-15,66 * * *$ & \\
\hline \multirow[t]{2}{*}{ Gönci magyar kajszi } & 0,965 & $274,32 * * *$ & konstans & $-400,77$ & $-14,82 * * *$ & $-21,2$ \\
\hline & & & $\mathrm{x}$ együttható & $-21,3$ & $-16,56 * * *$ & \\
\hline \multirow[t]{2}{*}{ Rózsakajszi C 1406} & 0,917 & $177,9 * * *$ & konstans & $-257,4$ & $-11,4 * * *$ & $-22,5$ \\
\hline & & & $\mathrm{x}$ együttható & $-13,7$ & $-13,34 * * *$ & \\
\hline \multicolumn{7}{|c|}{ 2011. január 2.} \\
\hline \multirow[t]{2}{*}{ Ceglédi bíborkajszi } & 0,963 & $414,7 * * *$ & konstans & $-341,98$ & $-17,55 * * *$ & $-20,8$ \\
\hline & & & $\mathrm{x}$ együttható & $-18,84$ & $-20,36^{* * *}$ & \\
\hline \multirow[t]{2}{*}{ Gönci magyar kajszi } & 0,971 & $330,3 * * *$ & konstans & $-363,41$ & $-15,63 * * *$ & $-21,5$ \\
\hline & & & $\mathrm{x}$ együttható & $-19,19$ & $-18,17 * * *$ & \\
\hline \multirow[t]{2}{*}{ Rózsakajszi C 1406} & 0,954 & $333,17 * * *$ & konstans & $-299,4$ & $-15,81 * * *$ & $-23,3$ \\
\hline & & & $\mathrm{x}$ együttható & $-14,99$ & $-18,25 * * *$ & \\
\hline \multicolumn{7}{|c|}{ 2011. január 13.} \\
\hline \multirow[t]{2}{*}{ Ceglédi bíborkajszi } & 0,951 & $307,28 * * *$ & konstans & $-287,2$ & $-14,76^{* * *}$ & $-17,9$ \\
\hline & & & $\mathrm{x}$ együttható & $-18,9$ & $-17,53 * * *$ & \\
\hline \multirow[t]{2}{*}{ Gönci magyar kajszi } & 0,901 & $91,1 * * *$ & konstans & $-376,9$ & $-8,48 * * *$ & $-19,1$ \\
\hline & & & $\mathrm{x}$ együttható & $-22,3$ & $-9,55 * * *$ & \\
\hline \multirow[t]{2}{*}{ Rózsakajszi C 1406} & 0,961 & $244,6 * * *$ & konstans & $-491,7$ & $-14,04 * * *$ & $-20,8$ \\
\hline & & & $\mathrm{x}$ együttható & $-26,1$ & $-15,64 * * *$ & \\
\hline \multicolumn{7}{|c|}{ 2011. január 27.} \\
\hline \multirow[t]{2}{*}{ Ceglédi bíborkajszi } & 0,98 & $796,6 * * *$ & konstans & $-270,7$ & $-23,5 * * *$ & $-16,8$ \\
\hline & & & $\mathrm{x}$ együttható & $-19,1$ & $-28,2 * * *$ & \\
\hline \multirow[t]{2}{*}{ Gönci magyar kajszi } & 0,968 & $304,64 * * *$ & konstans & $-331,3$ & $-14,8 * * *$ & $-17,5$ \\
\hline & & & $\mathrm{x}$ együttható & $-21,8$ & $-17,5 * * *$ & \\
\hline \multirow[t]{2}{*}{ Rózsakajszi C 1406} & 0,935 & $229,12 * * *$ & konstans & $-257,68$ & $-12,4 * * *$ & $-18,6$ \\
\hline & & & $\mathrm{x}$ egvüttható & $-16,5$ & $-15,1 * * *$ & \\
\hline
\end{tabular}




\begin{tabular}{|c|c|c|c|c|c|c|}
\hline Fagytürés & $\mathbf{R}^{2}$ & $\mathbf{F}$ & \multicolumn{2}{|c|}{ Együtthatók } & $\mathbf{t}$ & $\mathbf{L T}_{\mathbf{5 0}}$ érték \\
\hline \multicolumn{7}{|c|}{ 2011. február 16.} \\
\hline \multirow[t]{2}{*}{ Ceglédi bíborkajszi } & 0,943 & $164,8 * * *$ & konstans & $-308,8$ & $-11,3 * * *$ & $-14,3$ \\
\hline & & & $\mathrm{x}$ együttható & $-25,03$ & $-12,8 * * *$ & \\
\hline \multirow[t]{2}{*}{ Gönci magyar kajszi } & 0,929 & $131,8 * * *$ & konstans & $-267,4$ & $-9,54 * * *$ & $-15,8$ \\
\hline & & & $\mathrm{x}$ együttható & $-20,1$ & $-11,5 * * *$ & \\
\hline \multirow[t]{2}{*}{ Rózsakajszi C 1406} & 0,944 & $168,82 * * *$ & konstans & $-271,2$ & $-11,58 * * *$ & $-16,9$ \\
\hline & & & $\mathrm{x}$ együttható & $-18,98$ & $-12,99 * * *$ & \\
\hline \multicolumn{7}{|c|}{ 2011. március 8.} \\
\hline \multirow[t]{2}{*}{ Ceglédi bíborkajszi } & 0,857 & $59,7 * * *$ & konstans & $-180,97$ & $-5,6 * * *$ & -11 \\
\hline & & & x együttható & -21 & $-7,7 * * *$ & \\
\hline \multirow[t]{2}{*}{ Gönci magyar kajszi } & 0,949 & $131,1 * * *$ & konstans & $-123,2$ & $-7,01 * * *$ & $-11,7$ \\
\hline & & & $\mathrm{x}$ együttható & $-14,7$ & $-11,5 * * *$ & \\
\hline \multirow[t]{2}{*}{ Rózsakajszi C 1406} & 0,948 & $183,8 * * *$ & konstans & $-248,4$ & $-5,3 * * *$ & $-12,5$ \\
\hline & & & $\mathrm{x}$ együttható & $-23,9$ & $-6,9 * * *$ & \\
\hline \multicolumn{7}{|c|}{ 2011. március 21.} \\
\hline \multirow[t]{2}{*}{ Ceglédi bíborkajszi } & 0,981 & $841,1 * * *$ & konstans & $-287,9$ & $-24,4 * * *$ & -8 \\
\hline & & & $\mathrm{x}$ együttható & $-42,5$ & $-29 * * *$ & \\
\hline \multirow[t]{2}{*}{ Gönci magyar kajszi } & 0,947 & $179,9 * * *$ & konstans & $-308,96$ & $-11,64 * * *$ & $-8,6$ \\
\hline & & & $\mathrm{x}$ együttható & $-41,8$ & $-13,4 * * *$ & \\
\hline \multirow[t]{2}{*}{ Rózsakajszi C 1406} & 0,959 & $235,4 * * *$ & konstans & $-464,4$ & $-13,8 * * *$ & $-9,5$ \\
\hline & & & $\mathrm{x}$ együttható & $-54,4$ & $-15,3 * * *$ & \\
\hline
\end{tabular}

$* * * \mathrm{p}<0,0001$ 
M.2.5. táblázat: A külföldi kajszifajták lineáris regresszióval becsült $\left(\mathrm{LT}_{50}\right)$ értékei a 2010/2011es évjáratban

\begin{tabular}{|c|c|c|c|c|c|c|}
\hline Fagytürés & $\mathbf{R}^{2}$ & $\mathbf{F}$ & \multicolumn{2}{|c|}{ Együtthatók } & $\mathbf{t}$ & $\mathbf{L T}_{50}$ érték \\
\hline \multicolumn{7}{|c|}{2010. október 7.} \\
\hline \multirow[t]{2}{*}{ Sylvercot (myrobalan) } & 0,956 & $346,8 * * *$ & konstans & $-254,8$ & $-15,3 * * *$ & $-15,8$ \\
\hline & & & $\mathrm{x}$ együttható & $-19,3$ & $-18,6 * * *$ & \\
\hline \multirow[t]{2}{*}{ Sylvercot (Missuri) } & 0,914 & $169,2 * * *$ & konstans & $-174,5$ & $-10,2 * * *$ & $-16,3$ \\
\hline & & & $\mathrm{x}$ együttható & $-13,8$ & $-13,01 * * *$ & \\
\hline \multirow[t]{2}{*}{ Sylvercot (C29) } & 0,976 & $485,8 * * *$ & konstans & $-245,02$ & $-18,02 * * *$ & $-15,9$ \\
\hline & & & $\mathrm{x}$ együttható & $-18,61$ & $-22,04 * * *$ & \\
\hline \multirow[t]{2}{*}{ Sylred (myrobalan) } & 0,933 & $138,3 * * *$ & konstans & $-357,7$ & $-10,59 * * *$ & $-17,5$ \\
\hline & & & $\mathrm{x}$ együttható & $-23,33$ & $-11,76^{* * *}$ & \\
\hline \multirow[t]{2}{*}{ Pinkcot (Missuri) } & 0,946 & $173,9 * * *$ & konstans & $-327,95$ & $-11,7 * * *$ & $-17,4$ \\
\hline & & & $\mathrm{x}$ együttható & $-21,78$ & $-13,2 * * *$ & \\
\hline \multirow[t]{2}{*}{ Goldrich (myrobalan) } & 0,973 & $583,8 * * *$ & konstans & $-248,4$ & $-19,8 * * *$ & $-15,9$ \\
\hline & & & $\mathrm{x}$ együttható & $-18,8$ & $-24,2 * * *$ & \\
\hline \multirow[t]{2}{*}{ Pisana (myrobalan) } & 0,953 & $200,78 * * *$ & konstans & $-240,6$ & $-12,4 * * *$ & -18 \\
\hline & & & $\mathrm{x}$ együttható & $-16,1$ & $-14,2 * * *$ & \\
\hline \multirow[t]{2}{*}{ Laycot (myrobalan) } & 0,921 & $116,1 * * *$ & konstans & $-325,03$ & $-9,32 * * *$ & -15 \\
\hline & & & $\mathrm{x}$ együttható & -25 & $-10,8 * * *$ & \\
\hline & & 2010 & október 19. & & & \\
\hline \multirow[t]{2}{*}{ Sylvercot (myrobalan) } & 0,98 & $775,2 * * *$ & konstans & $-324,1$ & $-23,9 * * *$ & $-17,9$ \\
\hline & & & $\mathrm{x}$ együttható & $-20,9$ & $-27,8 * * *$ & \\
\hline \multirow[t]{2}{*}{ Sylvercot (Missuri) } & 0,98 & $501,4 * * *$ & konstans & $-263,3$ & $-18,6 * * *$ & $-17,9$ \\
\hline & & & $\mathrm{x}$ együttható & $-17,5$ & $-22,4 * * *$ & \\
\hline \multirow[t]{2}{*}{ Sylvercot (C29) } & 0,978 & $680,9 * * *$ & konstans & $-309,95$ & $-22,1 * * *$ & $-17,7$ \\
\hline & & & $\mathrm{x}$ együttható & $-20,3$ & $-26,1 * * *$ & \\
\hline \multirow[t]{2}{*}{ Sylred (myrobalan) } & 0,91 & $91,5 * * *$ & konstans & $-403,9$ & $-8,6 * * *$ & $-19,2$ \\
\hline & & & $\mathrm{x}$ együttható & $-23,6$ & $-9,6 * * *$ & \\
\hline \multirow[t]{2}{*}{ Pinkcot (Missuri) } & 0,938 & $240,6 * * *$ & konstans & $-263,8$ & $-12,89 * * *$ & $-17,9$ \\
\hline & & & $\mathrm{x}$ együttható & $-17,6$ & $-15,5 * * *$ & \\
\hline \multirow[t]{2}{*}{ Goldrich (myrobalan) } & 0,952 & $315,032 * *$ & konstans & $-310,750$ & $-14,9 * * *$ & $-17,6$ \\
\hline & & & $\mathrm{x}$ együttható & $-20,5$ & $-17,7 * * *$ & \\
\hline \multirow[t]{2}{*}{ Pisana (myrobalan) } & 0,803 & $36,7 * *$ & konstans & $-352,1$ & $-5,3 * * * *$ & -19 \\
\hline & & & x együttható & $-19,7$ & $-6,1 * * *$ & \\
\hline \multirow[t]{2}{*}{ Laycot (myrobalan) } & 0,947 & $177,6 * * *$ & konstans & $-316,7$ & $-11,63 * * *$ & $-17,2$ \\
\hline & & & $\mathrm{x}$ együttható & $-21,3$ & $-13,33 * * *$ & \\
\hline
\end{tabular}


M.2.5. táblázat folytatása

\begin{tabular}{|c|c|c|c|c|c|c|}
\hline \multirow{2}{*}{ Fagytürés } & \multirow[t]{2}{*}{$\mathbf{R}^{2}$} & \multirow{2}{*}{$\frac{\mathbf{F}}{2010.1}$} & \multicolumn{2}{|c|}{ Együtthatók } & \multirow[t]{2}{*}{$\mathbf{t}$} & \multirow[t]{2}{*}{$\mathbf{L T}_{50}$ érték } \\
\hline & & & ovember 18 . & & & \\
\hline \multirow[t]{2}{*}{ Sylvercot (myrobalan) } & 0,854 & $58,3 * * *$ & konstans & $-297,01$ & $-6,634 * * *$ & $-18,3$ \\
\hline & & & $\mathrm{x}$ együttható & $-18,96$ & $-7,634 * * *$ & \\
\hline \multirow[t]{2}{*}{ Sylvercot (Missuri) } & 0,898 & $88,42 * * *$ & konstans & $-289,6$ & $-8,36 * * *$ & $-18,8$ \\
\hline & & & $\mathrm{x}$ együttható & $-18,1$ & $-9,403 * * *$ & \\
\hline \multirow[t]{2}{*}{ Sylvercot (C29) } & 0,908 & $88,43 * * *$ & konstans & $-318,5$ & $-8,42 * * *$ & $-18,6$ \\
\hline & & & x együttható & $-19,8$ & $-9,4 * * *$ & \\
\hline \multirow[t]{2}{*}{ Sylred (myrobalan) } & 0,962 & $251,2 * * *$ & konstans & $-537,6$ & $-14,2 * * *$ & $-19,5$ \\
\hline & & & $\mathrm{x}$ együttható & $-30,1$ & $-15,9 * * *$ & \\
\hline \multirow[t]{2}{*}{ Pinkcot (Missuri) } & 0,904 & $94,42 * * *$ & konstans & $-526,2$ & $-8,99 * * *$ & $-18,3$ \\
\hline & & & $\mathrm{x}$ együttható & $-31,55$ & $-9,72 * * *$ & \\
\hline \multirow[t]{2}{*}{ Goldrich (myrobalan) } & 0,957 & $359,4 * * *$ & konstans & $-326,3$ & $-16,2 * * *$ & $-18,8$ \\
\hline & & & $\mathrm{x}$ együttható & $-20,05$ & $-18,96 * * *$ & \\
\hline \multirow[t]{2}{*}{ Pisana (myrobalan) } & 0,975 & $629,6 * * *$ & konstans & $-334,3$ & $-21,8 * * *$ & -19 \\
\hline & & & $\mathrm{x}$ együttható & $-20,2$ & $-25,1 * * *$ & \\
\hline \multirow[t]{2}{*}{ Laycot (myrobalan) } & 0,909 & $100,06 * * *$ & konstans & $-363,3$ & $-8,7 * * *$ & $-17,9$ \\
\hline & & & $\mathrm{x}$ együttható & $-23,1$ & $-10 * * *$ & \\
\hline \multirow{3}{*}{ Sylvercot (myrobalan) } & & 2010 & lecember 14. & & & \\
\hline & 0,909 & $99,6 * * *$ & konstans & $-494,8$ & $-8,9 * * *$ & $-18,6$ \\
\hline & & & $\mathrm{x}$ együttható & $-29,3$ & $-9,98 * * *$ & \\
\hline \multirow[t]{2}{*}{ Sylvercot (Missuri) } & 0,984 & $596,3 * * *$ & konstans & $-628,7$ & $-22,2 * * *$ & $-18,7$ \\
\hline & & & $\mathrm{x}$ együttható & $-36,3$ & $-24,4 * * *$ & \\
\hline \multirow[t]{2}{*}{ Sylvercot (C29) } & 0,977 & $432,4 * * *$ & konstans & $-603,002$ & $-18,8 * * *$ & $-18,6$ \\
\hline & & & x együttható & $-35,1$ & $-20,8 * * *$ & \\
\hline \multirow[t]{2}{*}{ Sylred (myrobalan) } & 0,962 & $401,6 * * *$ & konstans & $-520,7$ & $-18,2 * * *$ & $-19,6$ \\
\hline & & & $\mathrm{x}$ együttható & $-29,1$ & $-20,04 * * *$ & \\
\hline \multirow[t]{2}{*}{ Pinkcot (Missuri) } & 0,957 & $223,8 * * *$ & konstans & $-554,4$ & $-13,4 * * *$ & $-18,6$ \\
\hline & & & $\mathrm{x}$ együttható & $-32,6$ & $-14,96^{* * *}$ & \\
\hline \multirow[t]{2}{*}{ Goldrich (myrobalan) } & 0,976 & $408,5 * * *$ & konstans & $-610,7$ & $-18,5 * * *$ & $-18,8$ \\
\hline & & & $\mathrm{x}$ együttható & $-35,1$ & $-20,2 * * *$ & \\
\hline \multirow[t]{2}{*}{ Pisana (myrobalan) } & 0,905 & $95,621 * * *$ & konstans & $-393,94$ & $-8,9 * * *$ & $-19,5$ \\
\hline & & & $\mathrm{x}$ együttható & $-22,8$ & $-9,8 * * *$ & \\
\hline \multirow[t]{2}{*}{ Laycot (myrobalan) } & 0,966 & $285,4 * * *$ & konstans & $-391,02$ & $-14,3 * * *$ & $-18,1$ \\
\hline & & & $\mathrm{x}$ együttható & $-24,3$ & $-16,9 * * *$ & \\
\hline
\end{tabular}


M.2.5. táblázat folytatása

\begin{tabular}{|c|c|c|c|c|c|c|}
\hline \multirow{2}{*}{$\begin{array}{c}\text { Fagytürés } \\
\text { Sylvercot (myrobalan) }\end{array}$} & \multirow{2}{*}{$\begin{array}{c}\mathbf{R}^{2} \\
0,983\end{array}$} & \multirow{2}{*}{$\frac{\mathbf{F}}{2011}$} & \multicolumn{2}{|c|}{ Együtthatók } & $\mathbf{t}$ & \multirow{2}{*}{$\begin{array}{c}\mathbf{L T}_{\mathbf{5 0}} \text { érték } \\
-18,8\end{array}$} \\
\hline \multicolumn{7}{|l|}{ 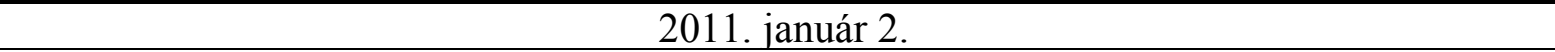 } \\
\hline & & & $\begin{array}{c}\text { konstans } \\
\mathrm{x} \text { együttható }\end{array}$ & $\begin{array}{l}-336,8 \\
-20,6\end{array}$ & $\begin{array}{l}-26,05 * * * \\
-30,4 * * *\end{array}$ & \\
\hline Sylvercot (Missuri) & 0,877 & $71,3 * * *$ & $\begin{array}{c}\text { konstans } \\
\mathrm{x} \text { együttható }\end{array}$ & $\begin{array}{l}-300 \\
-18,7\end{array}$ & $\begin{array}{l}-6,75 * * * \\
-8,44 * * *\end{array}$ & $-18,7$ \\
\hline Sylvercot (C29) & 0,947 & $588,5 * * *$ & $\begin{array}{c}\text { konstans } \\
\mathrm{x} \text { együttható }\end{array}$ & $\begin{array}{c}-296,98 \\
-18,7\end{array}$ & $\begin{array}{l}-20,2 * * * \\
-24,3 * * *\end{array}$ & $-18,6$ \\
\hline Sylred (myrobalan) & 0,938 & $135,1 * * *$ & $\begin{array}{c}\text { konstans } \\
\text { x együttható }\end{array}$ & $\begin{array}{l}-400,1 \\
-22,5\end{array}$ & $\begin{array}{l}-10,4 * * * \\
-11,6 * * *\end{array}$ & -20 \\
\hline Pinkcot (Missuri) & 0,97 & $526,1 * * *$ & $\begin{array}{c}\text { konstans } \\
\text { x együttható }\end{array}$ & $\begin{array}{l}-327 \\
-20,24\end{array}$ & $\begin{array}{l}-19,43 * * * \\
-22,94 * * *\end{array}$ & $-18,6$ \\
\hline Goldrich (myrobalan) & 0,978 & $698,2 * * *$ & $\begin{array}{c}\text { konstans } \\
\text { x együttható }\end{array}$ & $\begin{array}{l}-310,4 \\
-19,1\end{array}$ & $\begin{array}{l}-22,5 * * * \\
-26,4 * * *\end{array}$ & $-18,9$ \\
\hline Pisana (myrobalan) & 0,971 & $543,8 * * *$ & $\begin{array}{c}\text { konstans } \\
\text { x együttható }\end{array}$ & $\begin{array}{l}-233,7 \\
-14,5\end{array}$ & $\begin{array}{l}-19,7 * * * \\
-23,3 * * *\end{array}$ & $-19,6$ \\
\hline Laycot (myrobalan) & 0,988 & $843,2 * * *$ & $\begin{array}{c}\text { konstans } \\
\text { x együttható }\end{array}$ & $\begin{array}{l}-494,5 \\
-29,9\end{array}$ & $\begin{array}{c}-26,4 * * * \\
-29,04 * * *\end{array}$ & $-18,2$ \\
\hline & & 201 & . január 13. & & & \\
\hline Sylvercot (myrobalan) & 0,933 & $139,6^{* * *}$ & $\begin{array}{c}\text { konstans } \\
\mathrm{x} \text { együttható }\end{array}$ & $\begin{array}{l}-315,3 \\
-22,1\end{array}$ & $\begin{array}{l}-10,5 * * * \\
-11,8 * * *\end{array}$ & $-16,5$ \\
\hline Sylvercot (Missuri) & 0,821 & $45,8 * * *$ & $\begin{array}{c}\text { konstans } \\
\text { x együttható }\end{array}$ & $\begin{array}{l}-278,2 \\
-20,3\end{array}$ & $\begin{array}{l}-5,8 * * * \\
-6,8 * * *\end{array}$ & $-16,2$ \\
\hline Sylvercot (C29) & 0,933 & $138,9 * * *$ & $\begin{array}{c}\text { konstans } \\
\text { x együttható }\end{array}$ & $\begin{array}{l}-300,3 \\
-21,9\end{array}$ & $\begin{array}{l}-10,1 * * * \\
-11,8 * * *\end{array}$ & -16 \\
\hline Sylred (myrobalan) & 0,91 & $101,2 * * *$ & $\begin{array}{c}\text { konstans } \\
\text { x együttható }\end{array}$ & $\begin{array}{l}-284,6 \\
-18,8\end{array}$ & $\begin{array}{c}-8,4 * * * \\
-10,1 * * *\end{array}$ & $-17,8$ \\
\hline Pinkcot (Missuri) & 0,91 & $142,3 * * *$ & $\begin{array}{c}\text { konstans } \\
\text { x együttható }\end{array}$ & $\begin{array}{l}-207,8 \\
-14,7\end{array}$ & $\begin{array}{c}-9,7 * * * \\
-11,9 * * *\end{array}$ & $-17,5$ \\
\hline Goldrich (myrobalan) & 0,970 & $452,4 * * *$ & $\begin{array}{c}\text { konstans } \\
\mathrm{x} \text { együttható }\end{array}$ & $\begin{array}{l}-212,4 \\
-15,2\end{array}$ & $\begin{array}{l}-17,5 * * * \\
-21,3 * * *\end{array}$ & $-17,2$ \\
\hline Pisana (myrobalan) & 0,914 & $106,9 * * *$ & $\begin{array}{c}\text { konstans } \\
\text { x együttható }\end{array}$ & $\begin{array}{l}-303,8 \\
-19,7\end{array}$ & $\begin{array}{c}-8,9 * * * \\
-10,3 * * *\end{array}$ & -18 \\
\hline Laycot (myrobalan) & 0,948 & $182,2 * * *$ & $\begin{array}{c}\text { konstans } \\
\text { x együttható }\end{array}$ & $\begin{array}{l}-308,3 \\
-22,3\end{array}$ & $\begin{array}{l}-11,6 * * * \\
-13,5 * * *\end{array}$ & -16 \\
\hline
\end{tabular}


M.2.5. táblázat folytatása

\begin{tabular}{|c|c|c|c|c|c|c|}
\hline Fagytürés & $\mathbf{R}^{2}$ & $\mathbf{F}$ & \multicolumn{2}{|c|}{ Együtthatók } & $\mathbf{t}$ & $\mathbf{L T}_{50}$ érték \\
\hline \multicolumn{7}{|c|}{ 2011. február 21.} \\
\hline \multirow[t]{2}{*}{ Sylvercot (myrobalan) } & 0,847 & $33,3 * *$ & konstans & $-199,6$ & $-4,7 *$ & $-13,3$ \\
\hline & & & $\mathrm{x}$ együttható & $-18,8$ & $-5,8 * * *$ & \\
\hline \multirow[t]{2}{*}{ Sylvercot (Missuri) } & 0,801 & $52,3 * * *$ & konstans & $-149,3$ & $-4,97 * * *$ & $-12,3$ \\
\hline & & & $\mathrm{x}$ együttható & $-16,1$ & $-7,2 * * *$ & \\
\hline \multirow[t]{2}{*}{ Sylvercot (C29) } & 0,868 & $32,7 * *$ & konstans & $-61,1$ & $-2,8^{*}$ & $-11,6$ \\
\hline & & & $\mathrm{x}$ együttható & $-9,6$ & $-5,7 *$ & \\
\hline \multirow[t]{2}{*}{ Sylred (myrobalan) } & 0,902 & $100,7 * * *$ & konstans & $-147,4$ & $-7,5 * * *$ & $-13,5$ \\
\hline & & & $\mathrm{x}$ együttható & $-14,6$ & $-10,04 * * *$ & \\
\hline \multirow[t]{2}{*}{ Pinkcot (Missuri) } & 0,932 & $54,5 *$ & konstans & $-184,4$ & $-5,9 *$ & $-13,4$ \\
\hline & & & $\mathrm{x}$ együttható & $-17,5$ & $-7,4^{*}$ & \\
\hline \multirow[t]{2}{*}{ Goldrich (myrobalan) } & 0,949 & $131,1 * * *$ & konstans & $-123,2$ & $-7,01 * * *$ & $-11,8$ \\
\hline & & & $\mathrm{x}$ együttható & $-14,6$ & $-11,5 * * *$ & \\
\hline \multirow[t]{2}{*}{ Pisana (myrobalan) } & 0,891 & $90,2 * * *$ & konstans & $-134,2$ & $-7,05 * * *$ & $-13,7$ \\
\hline & & & $\mathrm{x}$ együttható & $-13,5$ & $-9,5 * * *$ & \\
\hline \multirow[t]{2}{*}{ Laycot (myrobalan) } & 0,836 & $35,8 * * *$ & konstans & $-180,8$ & $-4,7^{*}$ & $-13,4$ \\
\hline & & & $\mathrm{x}$ együttható & $-17,7$ & $-5,98 * * *$ & \\
\hline
\end{tabular}

$* \mathrm{p}<0,05 * * \mathrm{p} \leq 0,01 \quad * * * \mathrm{p} \leq 0,001$ 
M.2.6. táblázat: A standard fajták lineáris regresszióval becsült ( $\left.\mathrm{LT}_{50}\right)$ értékei a 2011/2012-es évjáratban

\begin{tabular}{|c|c|c|c|c|c|c|}
\hline Fagytürés & $\mathbf{R}^{2}$ & $\mathbf{F}$ & \multicolumn{2}{|c|}{ Együtthatók } & $\mathbf{t}$ & $\mathbf{L T}_{\mathbf{5 0}}$ érték \\
\hline \multicolumn{7}{|c|}{ 2011. szeptember 1.} \\
\hline \multirow[t]{2}{*}{ Ceglédi bíborkajszi } & 0,973 & $372 * * *$ & konstans & $-50,6$ & $-19,1 * * *$ & -6 \\
\hline & & & $\mathrm{x}$ együttható & $-166,5$ & $-7,2 * * *$ & \\
\hline \multirow[t]{2}{*}{ Gönci magyar kajszi } & 0,905 & $95,5 * * *$ & konstans & $-28,5$ & $-9,8 * * *$ & $-7,6$ \\
\hline & & & $\mathrm{x}$ együttható & $-129,3$ & $-6,3 * * *$ & \\
\hline \multirow[t]{2}{*}{ Rózsakajszi C 1406} & 0,907 & $97,04 * * *$ & konstans & $-19,9$ & $-9,9 * * *$ & -9 \\
\hline & & & $\mathrm{x}$ együttható & $-50,6$ & $-19,1 * * *$ & \\
\hline \multicolumn{7}{|c|}{ 2011. szeptember 16} \\
\hline \multirow[t]{2}{*}{ Ceglédi bíborkajszi } & 0,987 & $788,8 * * *$ & konstans & $-284,001$ & $-23,5 * * *$ & $-9,9$ \\
\hline & & & $\mathrm{x}$ együttható & $-33,84$ & $-28,1 * * *$ & \\
\hline \multirow[t]{2}{*}{ Gönci magyar kajszi } & 0,904 & $93,9 * * *$ & konstans & $-314,3$ & $-8,1 * * *$ & $-11,6$ \\
\hline & & & $\mathrm{x}$ együttható & $-31,3$ & $-9,7 * * *$ & \\
\hline \multirow[t]{2}{*}{ Rózsakajszi C 1406} & 0,946 & $174,4 * * *$ & konstans & -272 & $-11,5 * * *$ & $-12,4$ \\
\hline & & & x együttható & $-26,03$ & $-13,2 * * *$ & \\
\hline \multicolumn{7}{|c|}{ 2011. október 4.} \\
\hline \multirow[t]{2}{*}{ Ceglédi bíborkajszi } & 0,857 & $59,7 * * *$ & konstans & $-180,97$ & $-5,6 * * *$ & $-11,2$ \\
\hline & & & $\mathrm{x}$ együttható & $-20,7$ & $-7,7 * * *$ & \\
\hline \multirow[t]{2}{*}{ Gönci magyar kajszi } & 0,948 & $183,8 * * *$ & konstans & $-248,4$ & $-11,6 * * *$ & $-12,4$ \\
\hline & & & x együttható & $-24,1$ & $-13,6 * * *$ & \\
\hline \multirow[t]{2}{*}{ Rózsakajszi C 1406} & 0,827 & $47,97 * * *$ & konstans & $-185,4$ & $-5,3 * * *$ & $-13,5$ \\
\hline & & & $\mathrm{x}$ együttható & $-17,4$ & $-6,9 * * *$ & \\
\hline \multicolumn{7}{|c|}{ 2011. október 17.} \\
\hline \multirow[t]{2}{*}{ Ceglédi bíborkajszi } & 0,979 & $456,5 * * *$ & konstans & $-371,5$ & $-18,7 * * *$ & $-14,9$ \\
\hline & & & $\mathrm{x}$ együttható & $-28,3$ & $-21,4 * * *$ & \\
\hline \multirow[t]{2}{*}{ Gönci magyar kajszi } & 0,974 & $374,9 * * *$ & konstans & -354 & $-16,5 * * *$ & $-16,5$ \\
\hline & & & x együttható & $-24,4$ & $-19,4 * * *$ & \\
\hline \multirow[t]{2}{*}{ Rózsakajszi C 1406} & 0,914 & $106,8 * * *$ & konstans & $-373,9$ & $-9 * * *$ & $-18,8$ \\
\hline & & & $\mathrm{x}$ együttható & $-22,5$ & $-10,3 * * *$ & \\
\hline \multirow{3}{*}{ Ceglédi bíborkajszi } & & 2011 & november 14. & & & \\
\hline & 0,968 & $482,6 * * *$ & konstans & $-294,1$ & $-18,4 * * *$ & $-18,6$ \\
\hline & & & $\mathrm{x}$ együttható & $-18,5$ & $-21,97 * * *$ & \\
\hline \multirow[t]{2}{*}{ Gönci magyar kajszi } & 0,911 & $102,6 * * *$ & konstans & $-367,7$ & $-8,8 * * *$ & $-19,7$ \\
\hline & & & $\mathrm{x}$ együttható & $-21,2$ & $-10,1 * * *$ & \\
\hline \multirow[t]{2}{*}{ Rózsakajszi C 1406} & 0,944 & $269,6 * * *$ & konstans & $-317,9$ & $-14,1 * * *$ & $-20,9$ \\
\hline & & & $\mathrm{x}$ együttható & $-17,6$ & $-16,4 * * *$ & \\
\hline \multirow{3}{*}{ Ceglédi bíborkajszi } & & 201 & december 9 . & & & \\
\hline & 0,954 & $205,1 * * *$ & konstans & $-567,3$ & $-13,1 * * *$ & $-19,9$ \\
\hline & & & $\mathrm{x}$ együttható & $-31,01$ & $-14,3 * * *$ & \\
\hline \multirow[t]{2}{*}{ Gönci magyar kajszi } & 0,933 & $237 * * *$ & konstans & $-311,2$ & $-13,02 * * *$ & $-20,7$ \\
\hline & & & $\mathrm{x}$ együttható & $-17,5$ & $-15,4 * * *$ & \\
\hline \multirow[t]{2}{*}{ Rózsakajszi C 1406} & 0,951 & $310,6 * * *$ & konstans & $-252,6$ & $-13,9 * * *$ & $-21,8$ \\
\hline & & & $\mathrm{x}$ együttható & $-13,91$ & $-17,6 * * *$ & \\
\hline
\end{tabular}




\begin{tabular}{|c|c|c|c|c|c|c|}
\hline \multirow{2}{*}{ Fagytürés } & \multirow[t]{2}{*}{$\mathbf{R}^{2}$} & \multirow{2}{*}{$\frac{\mathbf{F}}{2011 .}$} & \multicolumn{2}{|c|}{ Együtthatók } & \multirow[t]{2}{*}{$\mathbf{t}$} & \multirow[t]{2}{*}{$\mathbf{L} \mathbf{T}_{50}$ érték } \\
\hline & & & december 22 . & & & \\
\hline \multirow[t]{2}{*}{ Ceglédi bíborkajszi } & 0,933 & $138,5 * * *$ & konstans & $-466,8$ & $-10,9 * * *$ & $-20,5$ \\
\hline & & & x együttható & $-25,2$ & $-11,8 * * *$ & \\
\hline \multirow[t]{2}{*}{ Gönci magyar kajszi } & 0,977 & $674,5 * * *$ & konstans & $-316,5$ & $-22,8 * * *$ & $-21,4$ \\
\hline & & & $\mathrm{x}$ együttható & $-17,1$ & $-25,97 * * *$ & \\
\hline \multirow[t]{2}{*}{ Rózsakajszi C 1406} & 0,951 & $271,4 * * *$ & konstans & $-299,98$ & $-14,2 * * *$ & -23 \\
\hline & & & $\mathrm{x}$ együttható & $-15,2$ & $-16,5 * * *$ & \\
\hline \multicolumn{7}{|c|}{ 2012. január 9.} \\
\hline \multirow[t]{2}{*}{ Ceglédi bíborkajszi } & 0,921 & $116,96^{* * *}$ & konstans & $-263,8$ & $-8,3 * * *$ & $-18,3$ \\
\hline & & & $\mathrm{x}$ együttható & $-17,2$ & $-10,8 * * *$ & \\
\hline \multirow[t]{2}{*}{ Gönci magyar kajszi } & 0,963 & $411,04 * * *$ & konstans & $-292,4$ & $-16,6 * * *$ & $-20,2$ \\
\hline & & & $\mathrm{x}$ együttható & $-16,95$ & $-20,3 * * *$ & \\
\hline \multirow[t]{2}{*}{ Rózsakajszi C 1406} & 0,981 & $821,1 * * *$ & konstans & $-242,6$ & $-21,995 * * *$ & $-21,3$ \\
\hline & & & x együttható & $-13,7$ & $-28,66^{* * *}$ & \\
\hline \multicolumn{7}{|c|}{ 2012. február 7} \\
\hline \multirow[t]{2}{*}{ Ceglédi bíborkajszi } & 0,973 & $363,5 * * *$ & konstans & -347 & $-17,1 * * *$ & $-16,5$ \\
\hline & & & $\mathrm{x}$ együttható & $-24,1$ & $-19,1 * * *$ & \\
\hline \multirow[t]{2}{*}{ Gönci magyar kajszi } & 0,972 & $351 * * *$ & konstans & $-414,7$ & $-16,6 * * *$ & $-17,9$ \\
\hline & & & x együttható & $-25,9$ & $-18,7 * * *$ & \\
\hline \multirow[t]{2}{*}{ Rózsakajszi C 1406} & 0,984 & $983,1 * * *$ & konstans & $-274,4$ & $-27,04 * * *$ & $-19,4$ \\
\hline & & & x együttható & $-16,7$ & $-31,4 * * *$ & \\
\hline \multirow{3}{*}{ Ceglédi bíborkajszi } & & 2012 & február 21. & & & \\
\hline & 0,982 & $534,9 * * *$ & konstans & $-348,8$ & $-20,1 * * *$ & -16 \\
\hline & & & x együttható & $-24,98$ & $-23,1 * * *$ & \\
\hline \multirow[t]{2}{*}{ Gönci magyar kajszi } & 0,988 & $1296,5 * * *$ & konstans & $-192,6$ & $-29,01 * * *$ & $-17,3$ \\
\hline & & & x együttható & -14 & $-36,01 * * *$ & \\
\hline \multirow[t]{2}{*}{ Rózsakajszi C 1406} & 0,965 & $444,3 * * *$ & konstans & $-161,2$ & $-17,5 * * *$ & $-18,6$ \\
\hline & & & x együttható & $-11,4$ & $-21,1 * * *$ & \\
\hline \multirow{3}{*}{ Ceglédi bíborkajszi } & & 2012 & március 12. & & & \\
\hline & 0,993 & $1477,4 * * *$ & konstans & $-267,4$ & $-33,9 * * *$ & $-10,5$ \\
\hline & & & x együttható & $-30,2$ & $-38,4 * * *$ & \\
\hline \multirow[t]{2}{*}{ Gönci magyar kajszi } & 0,971 & $332,5 * * *$ & konstans & $-195,6$ & $-13,7 * * *$ & $-11,4$ \\
\hline & & & x együttható & $-21,6$ & $-18,2 * * *$ & \\
\hline \multirow[t]{2}{*}{ Rózsakajszi C 1406} & 0,986 & $1125,7 * * *$ & konstans & $-175,3$ & $-25,1 * * *$ & $-12,6$ \\
\hline & & & x együttható & $-17,9$ & $-33,6 * * *$ & \\
\hline
\end{tabular}

$* * * \mathrm{p}<0,0001$ 
M.2.7. táblázat: A külföldi kajszifajták lineáris regresszióval becsült ( LT $\left._{50}\right)$ értékei a 2011/2012es évjáratban

\begin{tabular}{|c|c|c|c|c|c|c|}
\hline Fagytürés & $\mathbf{R}^{2}$ & $\mathbf{F}$ & \multicolumn{2}{|c|}{ Együtthatók } & $\mathbf{t}$ & $\mathbf{L T}_{50}$ érték \\
\hline \multicolumn{7}{|c|}{ 2011. szeptember 16} \\
\hline \multirow[t]{2}{*}{ Goldrich } & 0,944 & $168,2 * * *$ & konstans & $-263,9$ & $-10,9 * * *$ & $-10,1$ \\
\hline & & & $\mathrm{x}$ együttható & $-31,1$ & $-12,97 * * *$ & \\
\hline \multirow[t]{2}{*}{ Pinkcot } & 0,905 & $95,5 * * *$ & konstans & $-166,5$ & $-7,2 * * *$ & $-7,8$ \\
\hline & & & $\mathrm{x}$ együttható & $-27,9$ & $-9,8 * * *$ & \\
\hline \multirow[t]{2}{*}{ Sylvercot } & 0,927 & $126,97 * * *$ & konstans & $-203,8$ & $-9,4 * * *$ & $-10,4$ \\
\hline & & & $\mathrm{x}$ együttható & $-24,4$ & $-11,3 * * *$ & \\
\hline \multirow[t]{2}{*}{ Orange Red } & 0,887 & $78,4 * * *$ & konstans & $-180,1$ & $-7,03 * * *$ & $-10,2$ \\
\hline & & & $\mathrm{x}$ együttható & $-22,6$ & $-8,9 * * *$ & \\
\hline \multirow[t]{2}{*}{ Sweet Red } & 0,907 & $97,04 * * *$ & konstans & $-129,3$ & $-6,3 * * *$ & $-8,9$ \\
\hline & & & $\mathrm{x}$ együttható & $-20,2$ & $-9,9 * * *$ & \\
\hline \multirow[t]{2}{*}{ Veecot } & 0,921 & $117,1 * * *$ & konstans & $-192,2$ & $-8,8 * * *$ & $-10,3$ \\
\hline & & & $\mathrm{x}$ együttható & $-23,4$ & $-10,8 * * *$ & \\
\hline \multicolumn{7}{|c|}{ 2011. október 17.} \\
\hline \multirow[t]{2}{*}{ Goldrich } & 0,994 & $1778,6^{* * *}$ & konstans & $-545,2$ & $-39,03 * * *$ & $-15,2$ \\
\hline & & & $\mathrm{x}$ együttható & $-39,2$ & $-42,2 * * *$ & \\
\hline \multirow[t]{2}{*}{ Pinkcot } & 0,994 & $1608,3 * * *$ & konstans & $-231,7$ & $-29,9 * * *$ & $-13,6$ \\
\hline & & & $\mathrm{x}$ együttható & $-20,7$ & $-40,1 * * *$ & \\
\hline \multirow[t]{2}{*}{ Sylvercot } & 0,99 & $949,4 * * *$ & konstans & $-387,2$ & $-26,3 * * *$ & $-14,5$ \\
\hline & & & $\mathrm{x}$ együttható & $-30,2$ & $-30,8 * * *$ & \\
\hline \multirow[t]{2}{*}{ Orange Red } & 0,988 & $829,2 * * *$ & konstans & $-357,4$ & $-25,9 * * *$ & $-15,4$ \\
\hline & & & $\mathrm{x}$ együttható & $-26,4$ & $-28,8 * * *$ & \\
\hline \multirow[t]{2}{*}{ Sweet Red } & 0,985 & $646,7 * * *$ & konstans & $-258,3$ & $-19,6 * * *$ & $-13,8$ \\
\hline & & & $\mathrm{x}$ együttható & $-22,3$ & $-25,4 * * *$ & \\
\hline \multirow[t]{2}{*}{ Veecot } & 0,989 & $1387,4 * * *$ & konstans & $-272,2$ & $-31,5 * * *$ & $-16,2$ \\
\hline & & & x együttható & $-19,8$ & $-37,2 * * *$ & \\
\hline & & & 11. december & & & \\
\hline \multirow[t]{2}{*}{ Goldrich } & 0,967 & $465,1 * * *$ & konstans & $-348,12$ & $-18,84 * * *$ & -21 \\
\hline & & & $\mathrm{x}$ együttható & $-18,92$ & $-21,6 * * *$ & \\
\hline \multirow[t]{2}{*}{ Pinkcot } & 0,978 & $451,5 * * *$ & konstans & $-371,7$ & $-18,2 * * *$ & $-19,5$ \\
\hline & & & x együttható & $-21,7$ & $-21,2 * * *$ & \\
\hline \multirow[t]{2}{*}{ Sylvercot } & 0,99 & $13970,7 * * *$ & konstans & $-359,6$ & $-102,2 * * *$ & $-20,8$ \\
\hline & & & x együttható & $-19,7$ & $-118,2 * * *$ & \\
\hline \multirow[t]{2}{*}{ Orange Red } & 0,95 & $302,3 * * *$ & konstans & $-319,2$ & $-14,9 * * *$ & $-20,9$ \\
\hline & & & x együttható & $-17,7$ & $-17,4 * * *$ & \\
\hline \multirow[t]{2}{*}{ Sweet Red } & 0,877 & $71,3 * * *$ & konstans & -300 & $-6,75 * * *$ & $-18,7$ \\
\hline & & & $\mathrm{x}$ együttható & $-18,7$ & $-8,44 * * *$ & \\
\hline \multirow[t]{2}{*}{ Veecot } & 0,971 & $529,23 * * *$ & konstans & $-346,6$ & $-20,1 * * *$ & -21 \\
\hline & & & $\mathrm{x}$ együttható & $-18,9$ & $-23,01 * * *$ & \\
\hline
\end{tabular}


M.2.7. táblázat folytatása

\begin{tabular}{|c|c|c|c|c|c|c|}
\hline Fagytürés & $\mathbf{R}^{2}$ & $\mathbf{F}$ & \multicolumn{2}{|c|}{ Együtthatók } & $\mathbf{t}$ & $\mathbf{L T}_{50}$ érték \\
\hline \multicolumn{7}{|c|}{ 2012. január 9.} \\
\hline \multirow[t]{2}{*}{ Goldrich } & 0,928 & $205,9 * * *$ & konstans & $-220,9$ & $-11,9 * * *$ & $-20,6$ \\
\hline & & & $\mathrm{x}$ együttható & $-13,2$ & $-14,4 * * *$ & \\
\hline \multirow[t]{2}{*}{ Pinkcot } & 0,933 & $138,9 * * *$ & konstans & $-338,9$ & $-10,4 * * *$ & $-18,1$ \\
\hline & & & $\mathrm{x}$ együttható & $-21,5$ & $-11,8 * * *$ & \\
\hline \multirow[t]{2}{*}{ Sylvercot } & 0,952 & $318 * * *$ & konstans & $-249,02$ & $-14,9 * * *$ & $-18,6$ \\
\hline & & & x együttható & $-16,1$ & $-17,8 * * *$ & \\
\hline \multirow[t]{2}{*}{ Orange Red } & 0,909 & $160,6 * * *$ & konstans & $-289,98$ & $-10,9 * * *$ & $-20,7$ \\
\hline & & & $\mathrm{x}$ együttható & $-16,4$ & $-12,7 * * *$ & \\
\hline \multirow[t]{2}{*}{ Sweet Red } & 0,976 & $408,99 * * *$ & konstans & $-299,2$ & $-17,02 * * *$ & $-17,3$ \\
\hline & & & x együttható & $-20,2$ & $-20,2 * * *$ & \\
\hline \multirow[t]{2}{*}{ Veecot } & 0,9 & $143,4 * * *$ & konstans & $-317,02$ & $-10,33 * * *$ & $-20,4$ \\
\hline & & & $\mathrm{x}$ együttható & -18 & $-11,98 * * *$ & \\
\hline \multirow[t]{2}{*}{ Goldrich } & 0,928 & $205,9 * * *$ & konstans & $-220,9$ & $-11,9 * * *$ & $-20,6$ \\
\hline & & & x együttható & $-13,2$ & $-14,4 * * *$ & \\
\hline \multirow[t]{2}{*}{ Pinkcot } & 0,933 & $138,9 * * *$ & konstans & $-338,9$ & $-10,4 * * *$ & $-18,1$ \\
\hline & & & $\mathrm{x}$ együttható & $-21,5$ & $-11,8 * * *$ & \\
\hline
\end{tabular}

$* * * \mathrm{p}<0,0001$ 
M.2.8. táblázat: A standard fajták lineáris regresszióval becsült ( $\left.\mathrm{LT}_{50}\right)$ értékei a 2012/2013-as évjáratban

\begin{tabular}{|c|c|c|c|c|c|c|}
\hline Fagytürés & $\mathbf{R}^{2}$ & $\mathbf{F}$ & Együtth & tók & $\mathbf{t}$ & $\mathbf{L T}_{50}$ érték \\
\hline & & 2012. & zeptember 1. & & & \\
\hline Ceglédi bíborkajszi & 0,926 & $201,7 * * *$ & konstans & $-310,3$ & $-12,3 * * *$ & $-8,1$ \\
\hline & & & $\mathrm{x}$ együttható & $-44,7$ & $-14,2 * * *$ & \\
\hline Gönci magyar kajszi & 0,965 & $445,9 * * *$ & konstans & $-290,05$ & $-17,7 * * *$ & $-8,9$ \\
\hline & & & $\mathrm{x}$ együttható & $-38,2$ & $-21,1 * * *$ & \\
\hline Rózsakajszi C 1406 & 0,961 & $395,5 * * *$ & konstans & $-269,7$ & $-17,4 * * *$ & $-9,4$ \\
\hline & & & $\mathrm{x}$ együttható & $-34,1$ & $-19,9 * * *$ & \\
\hline & & $2012 . \mathrm{s}$ & zeptember 14. & & & \\
\hline Ceglédi bíborkajszi & 0,929 & $209,7 * * *$ & konstans & $-300,5$ & $-12,4 * * *$ & -10 \\
\hline & & & $\mathrm{x}$ együttható & $-35,04$ & $-14,5 * * *$ & \\
\hline Gönci magyar kajszi & 0,945 & $277,2 * * *$ & konstans & $-280,9$ & $-14,1 * * *$ & -11 \\
\hline & & & $\mathrm{x}$ együttható & $-30,1$ & $-16,7 * * *$ & \\
\hline Rózsakajszi C 1406 & 0,944 & $370,2 * * *$ & konstans & $-202,3$ & $-15,7 * * *$ & $-11,7$ \\
\hline & & & $\mathrm{x}$ együttható & $-21,5$ & $-19,2 * * *$ & \\
\hline & & 2012 & október 16. & & & \\
\hline Ceglédi bíborkajszi & 0,977 & $690,2 * * *$ & konstans & $-223,6$ & $-20,6 * * *$ & $-15,5$ \\
\hline & & & $\mathrm{x}$ együttható & $-17,7$ & $-26,3 * * *$ & \\
\hline Gönci magyar kajszi & 0,946 & $279,6 * * *$ & konstans & $-144,5$ & $-13,01 * * *$ & $-16,8$ \\
\hline & & & $\mathrm{x}$ együttható & $-11,5$ & $-16,7 * * *$ & \\
\hline Rózsakajszi C 1406 & 0,942 & $261,2 * * *$ & konstans & $-123,3$ & $-13,8 * * *$ & $-19,3$ \\
\hline & & & $\mathrm{x}$ együttható & $-8,98$ & $-16,2 * * *$ & \\
\hline & & 2012 & október 25. & & & \\
\hline Ceglédi bíborkajszi & 0,938 & $243,97 * * *$ & konstans & $-312,5$ & $-13,3 * * *$ & $-16,8$ \\
\hline & & & $\mathrm{x}$ együttható & $-21,5$ & $-15,6 * * *$ & \\
\hline Gönci magyar kajszi & 0,979 & $759,3 * * *$ & konstans & $-272,5$ & $-23,9 * * *$ & $-17,5$ \\
\hline & & & $\mathrm{x}$ együttható & $-18,4$ & $-27,6 * * *$ & \\
\hline Rózsakajszi C 1406 & 0,905 & $153,2 * * *$ & konstans & $-269,9$ & $-10,6^{* * *}$ & $-19,3$ \\
\hline & & & $\mathrm{x}$ együttható & $-16,6$ & $-12,4 * * *$ & \\
\hline & & 2012 & lovember 15 . & & & \\
\hline Ceglédi bíborkajszi & 0,947 & $284,8 * * *$ & konstans & $-267,7$ & $-13,74 * * *$ & $-18,5$ \\
\hline & & & $\mathrm{x}$ együttható & $-17,4$ & $-16,9 * * *$ & \\
\hline Gönci magyar kajszi & 0,929 & $208,6 * * *$ & konstans & $-253,6$ & $-12,2 * * *$ & $-19,3$ \\
\hline & & & $\mathrm{x}$ együttható & $-15,7$ & $-14,4 * * *$ & \\
\hline Rózsakajszi C 1406 & 0,909 & $159,96 * * *$ & konstans & $-177,4$ & $-11,1 * * *$ & $-21,5$ \\
\hline & & & $\mathrm{x}$ együttható & $-10,6$ & $-12,6 * * *$ & \\
\hline
\end{tabular}




\begin{tabular}{|c|c|c|c|c|c|c|}
\hline Fagytürés & $\mathbf{R}^{2}$ & $\mathbf{F}$ & \multicolumn{2}{|c|}{ Együtthatók } & $\mathbf{t}$ & $\mathbf{L T}_{50}$ érték \\
\hline \multicolumn{7}{|c|}{ 2012. november 28} \\
\hline \multirow[t]{2}{*}{ Ceglédi bíborkajszi } & 0,959 & $236,5 * * *$ & konstans & $-475,01$ & $-13,6 * * *$ & $-18,6$ \\
\hline & & & $\mathrm{x}$ együttható & $-28,2$ & $-15,4 * * *$ & \\
\hline \multirow[t]{2}{*}{ Gönci magyar kajszi } & 0,989 & $927,4 * * *$ & konstans & $-467,3$ & $-27,98 * * *$ & $-19,3$ \\
\hline & & & $\mathrm{x}$ együttható & $-26,7$ & $-30,5 * * *$ & \\
\hline \multirow[t]{2}{*}{ Rózsakajszi C 1406} & 0,947 & $177,5 * * *$ & konstans & $-307,7$ & $-11,1 * * *$ & $-20,4$ \\
\hline & & & $\mathrm{x}$ együttható & $-17,5$ & $-13,3 * * *$ & \\
\hline \multicolumn{7}{|c|}{ 2012. december 12 . } \\
\hline \multirow[t]{2}{*}{ Ceglédi bíborkajszi } & 0,972 & $349,9 * * *$ & konstans & $-652,5$ & $-17,3 * * *$ & -20 \\
\hline & & & $\mathrm{x}$ együttható & $-35,2$ & $-18,7 * * *$ & \\
\hline \multirow[t]{2}{*}{ Gönci magyar kajszi } & 0,984 & $1012,2 * * *$ & konstans & $-408,6$ & $-28,2 * * *$ & -21 \\
\hline & & & $\mathrm{x}$ együttható & $-21,9$ & $-31,8 * * *$ & \\
\hline \multirow[t]{2}{*}{ Rózsakajszi C 1406} & 0,937 & $149,2 * * *$ & konstans & $-427,4$ & $-11,02 * * *$ & $-22,2$ \\
\hline & & & $\mathrm{x}$ együttható & $-21,5$ & $-12,2 * * *$ & \\
\hline \multicolumn{7}{|c|}{ 2013. január 1.} \\
\hline \multirow[t]{2}{*}{ Ceglédi bíborkajszi } & 0,948 & $180,6 * * *$ & konstans & $-402,9$ & $-12,1 * * *$ & $-20,2$ \\
\hline & & & $\mathrm{x}$ együttható & $-22,4$ & $-13,4 * * *$ & \\
\hline \multirow[t]{2}{*}{ Gönci magyar kajszi } & 0,977 & $922,7 * * *$ & konstans & $-221,1$ & $-24,3 * * *$ & $-21,7$ \\
\hline & & & $\mathrm{x}$ együttható & $-12,5$ & $-30,4 * * *$ & \\
\hline \multirow[t]{2}{*}{ Rózsakajszi C 1406} & 0,978 & $958,9 * * *$ & konstans & $-183,01$ & $-25,2 * * *$ & $-22,9$ \\
\hline & & & $\mathrm{x}$ együttható & $-10,2$ & $-30,97 * * *$ & \\
\hline \multicolumn{7}{|c|}{ 2013. január 10.} \\
\hline \multirow[t]{2}{*}{ Ceglédi bíborkajszi } & 0,987 & $753,4 * * *$ & konstans & $-397,5$ & $-24,5 * * *$ & $-18,1$ \\
\hline & & & $\mathrm{x}$ együttható & $-24,7$ & $-27,4 * * *$ & \\
\hline \multirow[t]{2}{*}{ Gönci magyar kajszi } & 0,87 & $106,8 * * *$ & konstans & -247 & $-8,6 * * *$ & -19 \\
\hline & & & $\mathrm{x}$ együttható & $-15,65$ & $-10,3 * * *$ & \\
\hline \multirow[t]{2}{*}{ Rózsakajszi C 1406} & 0,938 & $135,1 * * *$ & konstans & $-400,1$ & $-10,4 * * *$ & -20 \\
\hline & & & $\mathrm{x}$ együttható & $-22,5$ & $-11,6 * * *$ & \\
\hline \multicolumn{7}{|c|}{ 2013. január 22.} \\
\hline \multirow[t]{2}{*}{ Ceglédi bíborkajszi } & 0,947 & $179,9 * * *$ & konstans & $-407,5$ & $-11,7 * * *$ & $-17,6$ \\
\hline & & & $\mathrm{x}$ együttható & $-25,96$ & $-13,4 * * *$ & \\
\hline \multirow[t]{2}{*}{ Gönci magyar kajszi } & 0,947 & $588,5 * * *$ & konstans & $-296,98$ & $-20,2 * * *$ & $-18,6$ \\
\hline & & & x együttható & $-18,7$ & $-24,3 * * *$ & \\
\hline \multirow[t]{2}{*}{ Rózsakajszi C 1406} & 0,964 & $433,2 * * *$ & konstans & $-301,8$ & $-17,8 * * *$ & $-19,1$ \\
\hline & & & $\mathrm{x}$ együttható & $-18,5$ & $-20,8 * * *$ & \\
\hline
\end{tabular}




\begin{tabular}{|c|c|c|c|c|c|c|}
\hline Fagytürés & $\mathbf{R}^{2}$ & $\mathbf{F}$ & \multicolumn{2}{|c|}{ Együtthatók } & $\mathbf{t}$ & $\mathbf{L T}_{50}$ érték \\
\hline \multicolumn{7}{|c|}{ 2013. február 11.} \\
\hline \multirow[t]{2}{*}{ Ceglédi bíborkajszi } & 0,984 & $627,9 * * *$ & konstans & $-446,03$ & $-22,5 * * *$ & -16 \\
\hline & & & $\mathrm{x}$ együttható & $-30,93$ & $-25,1 * * *$ & \\
\hline \multirow[t]{2}{*}{ Gönci magyar kajszi } & 0,971 & $530,8 * * *$ & konstans & $-264,7$ & $-19,3 * * *$ & -17 \\
\hline & & & $\mathrm{x}$ együttható & $-18,5$ & $-23,04 * * *$ & \\
\hline \multirow[t]{2}{*}{ Rózsakajszi C 1406} & 0,99 & $1595,1 * * *$ & konstans & $-244,5$ & $-34,2 * * *$ & $-17,6$ \\
\hline & & & $\mathrm{x}$ együttható & $-16,7$ & $-39,9 * * *$ & \\
\hline \multicolumn{7}{|c|}{ 2013. március 5.} \\
\hline \multirow[t]{2}{*}{ Ceglédi bíborkajszi } & 0,914 & $169,8 * * *$ & konstans & $-282,6$ & $-10,7 * * *$ & $-10,6$ \\
\hline & & & $\mathrm{x}$ együttható & $-31,3$ & $-13,03 * * *$ & \\
\hline \multirow[t]{2}{*}{ Gönci magyar kajszi } & 0,966 & $450 * * *$ & konstans & $-313,8$ & $-18,3 * * *$ & -12 \\
\hline & & & $\mathrm{x}$ együttható & $-30,3$ & $-21,2 * * *$ & \\
\hline \multirow[t]{2}{*}{ Rózsakajszi C 1406} & 0,901 & $144,8 * * *$ & konstans & $-179,1$ & $-10,3 * * *$ & $-13,2$ \\
\hline & & & $\mathrm{x}$ együttható & $-17,4$ & $-12,04 * * *$ & \\
\hline \multicolumn{7}{|c|}{ 2013. március 26.} \\
\hline \multirow[t]{2}{*}{ Ceglédi bíborkajszi } & 0,973 & $362,96 * * *$ & konstans & $-253,6$ & $-15,8 * * *$ & $-6,5$ \\
\hline & & & x együttható & $-46,9$ & $-19,1 * * *$ & \\
\hline \multirow[t]{2}{*}{ Gönci magyar kajszi } & 0,97 & $319,03 * * *$ & konstans & $-310,8$ & $-15,4 * * *$ & $-7,5$ \\
\hline & & & $\mathrm{x}$ együttható & $-47,98$ & $-17,9 * * *$ & \\
\hline \multirow[t]{2}{*}{ Rózsakajszi C 1406} & 0,952 & $433,3 * * *$ & konstans & $-85,5$ & $-14,3 * * *$ & $-9,4$ \\
\hline & & & $\mathrm{x}$ együttható & $-14,5$ & $-20,8 * * *$ & \\
\hline
\end{tabular}

$* * * \mathrm{p}<0,0001$ 
M.2.9. táblázat: A külföldi kajszifajták lineáris regresszióval becsült $\left(\mathrm{LT}_{50}\right)$ értékei a 2012/2013as évjáratban

\begin{tabular}{|c|c|c|c|c|c|c|}
\hline Fagytürés & $\mathbf{R}^{2}$ & $\mathbf{F}$ & \multicolumn{2}{|c|}{ Együtthatók } & $\mathbf{t}$ & $\mathbf{L T}_{50}$ érték \\
\hline \multicolumn{7}{|c|}{ 2012. október 16.} \\
\hline \multirow[t]{2}{*}{ Goldrich } & 0,985 & $1051,3 * * *$ & konstans & $-238,2$ & $-27,4 * * *$ & $-16,5$ \\
\hline & & & $\mathrm{x}$ együttható & $-17,5$ & $-32,4 * * *$ & \\
\hline \multirow[t]{2}{*}{ Pinkcot } & 0,977 & $425,96 * * *$ & konstans & $-355,2$ & $-18,3 * * *$ & $-15,2$ \\
\hline & & & $\mathrm{x}$ együttható & $-26,7$ & $-20,6 * * *$ & \\
\hline \multirow[t]{2}{*}{ Sylvercot } & 0,986 & $709,7 * * *$ & konstans & $-347,6$ & $-23,7 * * *$ & $-15,3$ \\
\hline & & & $\mathrm{x}$ együttható & $-25,98$ & $-26,6 * * *$ & \\
\hline \multirow[t]{2}{*}{ Aurora } & 0,982 & $544,3 * * *$ & konstans & $-416,97$ & $-20,9 * * *$ & $-15,1$ \\
\hline & & & $\mathrm{x}$ együttható & $-30,9$ & $-23,3 * * *$ & \\
\hline \multirow[t]{2}{*}{ Bergarouge } & 0,987 & $766,8 * * *$ & konstans & $-399,6$ & $-25,3 * * *$ & $-17,5$ \\
\hline & & & $\mathrm{x}$ együttható & $-25,7$ & $-27,7 * * *$ & \\
\hline \multirow[t]{2}{*}{ Harlayne } & 0,935 & $143,5 * * *$ & konstans & $-205,2$ & $-11 * * *$ & $-19,4$ \\
\hline & & & $\mathrm{x}$ együttható & $-13,1$ & $-12 * * *$ & \\
\hline \multicolumn{7}{|c|}{ 2012. november 15} \\
\hline \multirow[t]{2}{*}{ Goldrich } & 0,985 & $1040,2 * * *$ & konstans & $-331,8$ & $-27,9 * * *$ & -19 \\
\hline & & & $\mathrm{x}$ együttható & $-20,1$ & $-32,3 * * *$ & \\
\hline \multirow[t]{2}{*}{ Pinkcot } & 0,988 & $843,2 * * *$ & konstans & $-494,5$ & $-26,4 * * *$ & $-18,1$ \\
\hline & & & $\mathrm{x}$ együttható & $-30,2$ & $-29,04 * * *$ & \\
\hline \multirow[t]{2}{*}{ Sylvercot } & 0,97 & $526,1 * * *$ & konstans & -327 & $-19,43 * * *$ & $-18,6$ \\
\hline & & & $\mathrm{x}$ együttható & $-20,24$ & $-22,94 * * *$ & \\
\hline \multirow[t]{2}{*}{ Aurora } & 0,972 & $350,04 * * *$ & konstans & $-398,6$ & $-16,6 * * *$ & -18 \\
\hline & & & $\mathrm{x}$ együttható & $-24,9$ & $-18,7 * * *$ & \\
\hline \multirow[t]{2}{*}{ Bergarouge } & 0,942 & $257,6 * * *$ & konstans & $-269,1$ & $-13,7 * * *$ & $-19,3$ \\
\hline & & & $\mathrm{x}$ együttható & $-16,5$ & $-16,1 * * *$ & \\
\hline \multirow[t]{2}{*}{ Harlayne } & 0,97 & $324 * * *$ & konstans & $-359,95$ & $-16,2 * * *$ & $-20,5$ \\
\hline & & & $\mathrm{x}$ együttható & -20 & $-18 * * *$ & \\
\hline & & & 12. december & 12. & & \\
\hline \multirow[t]{2}{*}{ Goldrich } & 0,962 & $250,2 * * *$ & konstans & $-395,03$ & $-14,4 * * *$ & $-20,5$ \\
\hline & & & x együttható & $-21,7$ & $-15,8 * * *$ & \\
\hline \multirow[t]{2}{*}{ Pinkcot } & 0,978 & $698,2 * * *$ & konstans & $-310,4$ & $-22,5 * * *$ & $-18,9$ \\
\hline & & & x együttható & $-19,1$ & $-26,4 * * *$ & \\
\hline \multirow[t]{2}{*}{ Sylvercot } & 0,961 & $398,7 * * *$ & konstans & $-289,7$ & $-17,2 * * *$ & $-19,3$ \\
\hline & & & x együttható & $-17,6$ & $-20 * * *$ & \\
\hline \multirow[t]{2}{*}{ Aurora } & 0,983 & $925,4 * * *$ & konstans & $-336,8$ & $-26,05 * * *$ & $-18,8$ \\
\hline & & & $\mathrm{x}$ együttható & $-20,6$ & $-30,4 * * *$ & \\
\hline \multirow[t]{2}{*}{ Bergarouge } & 0,973 & $356,6 * * *$ & konstans & $-462,7$ & $-16,7 * * *$ & $-21,6$ \\
\hline & & & $\mathrm{x}$ együttható & $-23,8$ & $-18,9 * * *$ & \\
\hline \multirow[t]{2}{*}{ Harlayne } & 0,973 & $365,8 * * *$ & konstans & $-417,7$ & $-17,8 * * *$ & $-22,9$ \\
\hline & & & $\mathrm{x}$ együttható & $-20,4$ & $-19,1 * * *$ & \\
\hline
\end{tabular}


M.2.9. táblázat folytatása

\begin{tabular}{|c|c|c|c|c|c|c|}
\hline Fagytürés & $\mathbf{R}^{2}$ & $\mathbf{F}$ & \multicolumn{2}{|c|}{ Együtthatók } & $\mathbf{t}$ & $\mathbf{L} \mathbf{T}_{50}$ érték \\
\hline \multicolumn{7}{|c|}{ 2013. január 22.} \\
\hline \multirow[t]{2}{*}{ Goldrich } & 0,973 & $358,1 * * *$ & konstans & $-444,1$ & $-16,95 * * *$ & -18 \\
\hline & & & x együttható & $-27,5$ & $-18,9 * * *$ & \\
\hline \multirow[t]{2}{*}{ Pinkcot } & 0,983 & $917,4 * * *$ & konstans & $-313,4$ & $-26,03 * * *$ & -17 \\
\hline & & & $\mathrm{x}$ együttható & $-21,4$ & $-30,3 * * *$ & \\
\hline \multirow[t]{2}{*}{ Sylvercot } & 0,988 & $1291,4 * * *$ & konstans & $-322,6$ & $-30,97 * * *$ & -17 \\
\hline & & & $\mathrm{x}$ együttható & $-21,92$ & $-35,94 * * *$ & \\
\hline \multirow[t]{2}{*}{ Aurora } & 0,987 & $1189,7 * * *$ & konstans & $-265,5$ & $-28,4 * * *$ & $-16,7$ \\
\hline & & & $\mathrm{x}$ együttható & $-18,9$ & $-34,5 * * *$ & \\
\hline \multirow[t]{2}{*}{ Bergarouge } & 0,98 & $784,7 * * *$ & konstans & $-286,7$ & $-23,4 * * *$ & $-18,7$ \\
\hline & & & $\mathrm{x}$ együttható & $-17,98$ & $-28,01 * * *$ & \\
\hline \multirow[t]{2}{*}{ Harlayne } & 0,971 & $543,8 * * *$ & konstans & $-233,7$ & $-19,7 * * *$ & $-19,6$ \\
\hline & & & $\mathrm{x}$ együttható & $-14,5$ & $-23,3 * * *$ & \\
\hline \multicolumn{7}{|c|}{ 2013. február 11.} \\
\hline \multirow[t]{2}{*}{ Goldrich } & 0,959 & $378,1 * * *$ & konstans & $-283,9$ & $-16,1 * * *$ & $-16,7$ \\
\hline & & & $\mathrm{x}$ együttható & $-20,02$ & $-19,4 * * *$ & \\
\hline \multirow[t]{2}{*}{ Pinkcot } & 0,992 & $1235,3 * * *$ & konstans & $-410,1$ & $-30,9 * * *$ & $-15,8$ \\
\hline & & & x együttható & $-29,1$ & $-35,1 * * *$ & \\
\hline \multirow[t]{2}{*}{ Sylvercot } & 0,977 & $419,4 * * *$ & konstans & $-387,04$ & $-17,95 * * *$ & $-15,9$ \\
\hline & & & x együttható & $-27,5$ & $-20,5 * * *$ & \\
\hline \multirow[t]{2}{*}{ Aurora } & 0,978 & $441,3 * * *$ & konstans & $-372,8$ & $-17,8 * * *$ & $-15,4$ \\
\hline & & & $\mathrm{x}$ együttható & $-27,5$ & $-21,01 * * *$ & \\
\hline \multirow[t]{2}{*}{ Bergarouge } & 0,984 & $1014,5 * * *$ & konstans & $-256,2$ & $-27,1 * * *$ & $-17,4$ \\
\hline & & & x együttható & $-17,6$ & $-31,9 * * *$ & \\
\hline \multirow[t]{2}{*}{ Harlayne } & 0,98 & $497,5 * * *$ & konstans & $-361,6$ & $-19,9 * * *$ & $-18,3$ \\
\hline & & & $\mathrm{x}$ együttható & $-22,5$ & $-22,3 * * *$ & \\
\hline
\end{tabular}

$* * * p<0,0001$ 
M.2.10. táblázat: A standard fajták lineáris regresszióval becsült $\left(\mathrm{LT}_{50}\right)$ értékei a virágzás különböző fenofázisában 2011-ben

\begin{tabular}{|c|c|c|c|c|c|c|}
\hline Fagytürés & $\mathbf{R}^{2}$ & $\mathbf{F}$ & \multicolumn{2}{|c|}{ Együtthatók } & $\mathbf{t}$ & $\mathbf{L T}_{50}$ érték \\
\hline \multicolumn{7}{|c|}{ zárt csészebimbós állapot } \\
\hline \multirow[t]{2}{*}{ Ceglédi bíborkajszi } & 0,993 & $290 * *$ & konstans & $-34,8$ & $-6,5 *$ & $-5,2$ \\
\hline & & & $\mathrm{x}$ együttható & $-16,7$ & $-17,03 * *$ & \\
\hline \multirow[t]{2}{*}{ Gönci magyar kajszi } & 0,987 & $312,9 * * *$ & konstans & -225 & $-14,9 * * *$ & -6 \\
\hline & & & $\mathrm{x}$ együttható & $-45,8$ & $-17,7 * * *$ & \\
\hline \multirow[t]{2}{*}{ Rózsakajszi C 1406} & 0,993 & $576,9 * * *$ & konstans & -95 & $-15,1 * * *$ & $-7,1$ \\
\hline & & & $\mathrm{x}$ együttható & $-20,42$ & $-24,02 * * *$ & \\
\hline \multirow{3}{*}{ Ceglédi bíborkajszi } & & pattanó csé & szebimbós álla & pot & & \\
\hline & 0,971 & $134,8 * * *$ & konstans & $-27,1$ & $-4,1 *$ & $-5,1$ \\
\hline & & & $\mathrm{x}$ együttható & $-15,1$ & $-11,6 * * *$ & \\
\hline \multirow[t]{2}{*}{ Gönci magyar kajszi } & 0,998 & $1875 * * *$ & konstans & -375 & $-39,2 * * *$ & $-5,8$ \\
\hline & & & $\mathrm{x}$ együttható & $-73,3$ & $-43,3 * * *$ & \\
\hline \multirow[t]{2}{*}{ Rózsakajszi C 1406} & 0,992 & $510,6 * * *$ & konstans & $-255,84$ & $-19,8 * * *$ & $-6,9$ \\
\hline & & & $\mathrm{x}$ együttható & $-44,3$ & $-22,6 * * *$ & \\
\hline \multicolumn{7}{|c|}{ hólyagbimbós állapot } \\
\hline \multirow[t]{2}{*}{ Ceglédi bíborkajszi } & 0,964 & $188,5 * * *$ & konstans & $-125,9$ & $-9,5 * * *$ & $-4,5$ \\
\hline & & & $\mathrm{x}$ együttható & $-39,1$ & $-13,7 * * *$ & \\
\hline \multirow[t]{2}{*}{ Gönci magyar kajszi } & 0,977 & $173,3 * * *$ & konstans & -178 & $-11,2 * * *$ & $-5,5$ \\
\hline & & & $\mathrm{x}$ együttható & $-41,5$ & $-13,2 * * *$ & \\
\hline \multirow[t]{2}{*}{ Rózsakajszi C 1406} & 0,938 & $60 * *$ & konstans & -80 & $-5,6 * *$ & $-6,3$ \\
\hline & & & $\mathrm{x}$ együttható & $-20,6$ & $-7,8 * *$ & \\
\hline \multirow{3}{*}{ Ceglédi bíborkajszi } & & virá & zzás kezdet & & & \\
\hline & 0,955 & $147,04 * * *$ & konstans & $-81,04$ & $-7,02 * * *$ & -4 \\
\hline & & & $\mathrm{x}$ együttható & 32,76 & $-12,1 * * *$ & \\
\hline \multirow[t]{2}{*}{ Gönci magyar kajszi } & 0,951 & $135,1 * * *$ & konstans & $-63,7$ & $-6,64 * * *$ & -5 \\
\hline & & & $\mathrm{x}$ együttható & $-22,74$ & $-11,6 * * *$ & \\
\hline \multirow[t]{2}{*}{ Rózsakajszi C 1406} & 0,968 & $122,1 * * *$ & konstans & $-230,9$ & $-9,3 * *$ & $-5,7$ \\
\hline & & & $\mathrm{x}$ együttható & $-49,28$ & $-11,05 * * *$ & \\
\hline \multirow{3}{*}{ Ceglédi bíborkajszi } & & & virágzás & & & \\
\hline & 0,983 & $411,4 * * *$ & konstans & $-101,9$ & $-14,04 * * *$ & $-3,8$ \\
\hline & & & $\mathrm{x}$ együttható & -40 & $-20,3 * * *$ & \\
\hline \multirow[t]{2}{*}{ Gönci magyar kajszi } & 0,987 & $311,9 * * *$ & konstans & $-57,1$ & $-11,1 * * *$ & $-4,6$ \\
\hline & & & $\mathrm{x}$ együttható & $-23,3$ & $-17,7 * * *$ & \\
\hline \multirow[t]{2}{*}{ Rózsakajszi C 1406} & 0,991 & $767,1 * * *$ & konstans & $-140,8$ & $-20,5 * * *$ & $-5,3$ \\
\hline & & & $\mathrm{x}$ együttható & -36 & $-27,7 * * *$ & \\
\hline \multirow{3}{*}{ Ceglédi bíborkajszi } & & vir & gzás vége & & & \\
\hline & 0,964 & $105,9 * *$ & konstans & $-81,9$ & $-6,4 * *$ & $-3,5$ \\
\hline & & & $\mathrm{x}$ együttható & $-37,3$ & $-10,3 * *$ & \\
\hline \multirow[t]{2}{*}{ Gönci magyar kajszi } & 0,986 & $479,01 * * *$ & konstans & $-104,7$ & $-15,8 * * *$ & $-4,2$ \\
\hline & & & $\mathrm{x}$ együttható & $-36,8$ & $21,9 * * *$ & \\
\hline \multirow[t]{2}{*}{ Rózsakajszi C 1406} & 0,981 & $352 * * *$ & konstans & $-81,7$ & $-12,3 * * *$ & $-5,1$ \\
\hline & & & $\mathrm{x}$ együttható & $-25,8$ & $-18,8 * * *$ & \\
\hline
\end{tabular}

$* \mathrm{p}<0,05 ; * * \mathrm{p}<0,01 ; * * * \mathrm{p}<0,001$ 
M.2.11. táblázat: A standard fajták lineáris regresszióval becsült $\left(\mathrm{LT}_{50}\right)$ értékei a virágzás különböző fenofázisában 2012-ben

\begin{tabular}{|c|c|c|c|c|c|c|}
\hline Fagytürés & $\mathbf{R}^{2}$ & $\mathbf{F}$ & \multicolumn{2}{|c|}{ Együtthatók } & $\mathbf{t}$ & $\mathbf{L T}_{50}$ érték \\
\hline \multicolumn{7}{|c|}{ zárt csészebimbós állapot } \\
\hline \multirow[t]{2}{*}{ Ceglédi bíborkajszi } & 0,971 & $237,6 * * *$ & konstans & $-208,3$ & $-12,4 * * *$ & $-5,2$ \\
\hline & & & $\mathrm{x}$ együttható & $-49,67$ & $-15,4 * * *$ & \\
\hline \multirow[t]{2}{*}{ Gönci magyar kajszi } & 0,998 & $1875 * * *$ & konstans & -375 & $-39,2 * * *$ & $-5,8$ \\
\hline & & & $\mathrm{x}$ együttható & $-73,3$ & $-43,3 * * *$ & \\
\hline \multirow[t]{2}{*}{ Rózsakajszi C 1406} & 0,958 & $90,4 * *$ & konstans & -174 & $-7,9 * *$ & $-6,5$ \\
\hline & & & $\mathrm{x}$ együttható & $-34,5$ & $-9,5 * *$ & \\
\hline \multirow{3}{*}{ Ceglédi bíborkajszi } & & pattanó cs & szebimbós álla & oot & & \\
\hline & 0,96 & $96,3 * *$ & konstans & $-195,5$ & $-7,7 * *$ & $-5,1$ \\
\hline & & & $\mathrm{x}$ együttható & $-38,1$ & $-9,8 * *$ & \\
\hline \multirow[t]{2}{*}{ Gönci magyar kajszi } & 0,974 & $266,01 * * *$ & konstans & $-176,7$ & $-11,9 * * *$ & $-5,6$ \\
\hline & & & $\mathrm{x}$ együttható & $-40,48$ & $-16,3 * * *$ & \\
\hline \multirow[t]{2}{*}{ Rózsakajszi C 1406} & 0,983 & $238,3 * * *$ & konstans & $-238,4$ & $-12,9 * * *$ & $-6,1$ \\
\hline & & & $\mathrm{x}$ együttható & $-47,3$ & $-15,4 * * *$ & \\
\hline & & hólyag & imbós állapot & & & \\
\hline \multirow[t]{2}{*}{ Ceglédi bíborkajszi } & 0,979 & $320,3 * * *$ & konstans & $-89,8$ & $-11,8 * * *$ & $-3,8$ \\
\hline & & & $\mathrm{x}$ együttható & $-36,8$ & $-17,9 * * *$ & \\
\hline \multirow[t]{2}{*}{ Gönci magyar kajszi } & 0,997 & $2336,2 * * *$ & konstans & -70 & $-27,6 * * *$ & $-4,5$ \\
\hline & & & $\mathrm{x}$ együttható & $-26,7$ & $-30 * * *$ & \\
\hline \multirow[t]{2}{*}{ Rózsakajszi C 1406} & 0,99 & $387,2 * * *$ & konstans & -250 & $-16,2 * *$ & $-5,3$ \\
\hline & & & $\mathrm{x}$ együttható & $-56,6$ & $-19,7 * * *$ & \\
\hline \multicolumn{7}{|c|}{ virágzás kezdet } \\
\hline \multirow[t]{2}{*}{ Ceglédi bíborkajszi } & 0,988 & $559,2 * * *$ & konstans & $-122,4$ & $-18,4 * * *$ & $-3,5$ \\
\hline & & & $\mathrm{x}$ együttható & $-49,26$ & $-23,6 * * *$ & \\
\hline \multirow[t]{2}{*}{ Gönci magyar kajszi } & 0,993 & $602,1 * * *$ & konstans & -385 & $-22,2 * * *$ & $-4,2$ \\
\hline & & & $\mathrm{x}$ együttható & $-103,6$ & $-24,5 * * *$ & \\
\hline \multirow[t]{2}{*}{ Rózsakajszi C 1406} & 0,98 & $498,3 * * *$ & konstans & $-50,4$ & $-12,7 * * *$ & $-5,1$ \\
\hline & & & $\mathrm{x}$ együttható & $-19,7$ & $-22,3 * * *$ & \\
\hline \multirow{3}{*}{ Ceglédi bíborkajszi } & & & virágzás & & & \\
\hline & 0,979 & $190,7 * * *$ & konstans & $-148,8$ & $-10,6 * * *$ & -3 \\
\hline & & & $\mathrm{x}$ együttható & $-66,3$ & $-13,8 * * *$ & \\
\hline \multirow[t]{2}{*}{ Gönci magyar kajszi } & 0,987 & $300,7 * * *$ & konstans & $-171,03$ & $-13,6 * * *$ & $-3,8$ \\
\hline & & & $\mathrm{x}$ együttható & $-58,2$ & $-17,3 * * *$ & \\
\hline \multirow[t]{2}{*}{ Rózsakajszi C 1406} & 0,98 & $502 * * *$ & konstans & $-43,9$ & $-10,1 * * *$ & $-4,6$ \\
\hline & & & $\mathrm{x}$ együttható & $-20,41$ & $-22,4 * * *$ & \\
\hline \multirow{3}{*}{ Ceglédi bíborkajszi } & & & gzás vége & & & \\
\hline & 0,988 & $328 * * *$ & konstans & $-4,2$ & $-1,2 * *$ & $-1,9$ \\
\hline & & & $\mathrm{x}$ együttható & $-27,1$ & $-18,1 * * *$ & \\
\hline \multirow[t]{2}{*}{ Gönci magyar kajszi } & 0,993 & $555,5 * * *$ & konstans & $-56,1$ & $-12,04 * * *$ & $-2,6$ \\
\hline & & & $\mathrm{x}$ együttható & $-40,8$ & $-23,6 * * *$ & \\
\hline \multirow[t]{2}{*}{ Rózsakajszi C 1406} & 0,967 & $259,9 * * *$ & konstans & 14,7 & $-5,2 * *$ & $-3,4$ \\
\hline & & & $\mathrm{x}$ együttható & $-19,03$ & $-16,1 * * *$ & \\
\hline
\end{tabular}

$* * \mathrm{p}<0,01 ; * * * \mathrm{p}<0,001$ 
M.2.12. táblázat: A standard fajták lineáris regresszióval becsült $\left(\mathrm{LT}_{50}\right)$ értékei a virágzás különböző fenofázisában 2013-ban

\begin{tabular}{|c|c|c|c|c|c|c|}
\hline Fagytürés & $\mathbf{R}^{2}$ & $\mathbf{F}$ & \multicolumn{2}{|c|}{ Együtthatók } & $\mathbf{t}$ & $\mathbf{L T}_{50}$ érték \\
\hline \multicolumn{7}{|c|}{ zárt csészebimbós állapot } \\
\hline \multirow[t]{2}{*}{ Ceglédi bíborkajszi } & 0,955 & $82,5^{* *}$ & konstans & $-120,9$ & $-9,5^{* *}$ & $-4,4$ \\
\hline & & & $\mathrm{x}$ együttható & $-38,84$ & $-13,7 * *$ & \\
\hline \multirow[t]{2}{*}{ Gönci magyar kajszi } & 0,951 & $135,1 * * *$ & konstans & $-63,7$ & $-6,64 * * *$ & $-5,1$ \\
\hline & & & $\mathrm{x}$ együttható & $-22,3$ & $-11,6 * * *$ & \\
\hline \multirow[t]{2}{*}{ Rózsakajszi C 1406} & 0,958 & $90,4 * *$ & konstans & -174 & $-7,8 * *$ & $-6,4$ \\
\hline & & & $\mathrm{x}$ együttható & -35 & $-9,6^{* *}$ & \\
\hline \multirow{3}{*}{ Ceglédi bíborkajszi } & & pattanó cs & szebimbós áll & pot & & \\
\hline & 0,986 & $479 * * *$ & konstans & $-102,5$ & $-15,2 * * *$ & $-4,1$ \\
\hline & & & $\mathrm{x}$ együttható & $-37,2$ & $-21,3 * * *$ & \\
\hline \multirow[t]{2}{*}{ Gönci magyar kajszi } & 0,975 & $256,9 * * *$ & konstans & $-58,5$ & $-11,2 * * *$ & $-4,8$ \\
\hline & & & $\mathrm{x}$ együttható & $-22,6$ & $-17,5 * * *$ & \\
\hline \multirow[t]{2}{*}{ Rózsakajszi C 1406} & 0,942 & $174,5 * *$ & konstans & $-242,4$ & $-12,9 * * *$ & -6 \\
\hline & & & x együttható & $-48,7$ & $-15,6^{* * *}$ & \\
\hline \multicolumn{7}{|c|}{ hólyagbimbós állapot } \\
\hline \multirow[t]{2}{*}{ Ceglédi bíborkajszi } & 0,917 & $95,3 * *$ & konstans & $-129,4$ & $-9,7 * *$ & $-2,8$ \\
\hline & & & $\mathrm{x}$ együttható & $-64,1$ & $-10,6 * * *$ & \\
\hline \multirow[t]{2}{*}{ Gönci magyar kajszi } & 0,967 & $300,6 * * *$ & konstans & $-154,84$ & $-13,9 * * *$ & $-3,8$ \\
\hline & & & x együttható & $-53,9$ & $-17,4 * * *$ & \\
\hline \multirow[t]{2}{*}{ Rózsakajszi C 1406} & 0,966 & $154,7 * * *$ & konstans & $-51,4$ & $-11,6 * *$ & $-5,2$ \\
\hline & & & $\mathrm{x}$ együttható & $-19,5$ & $-23,4 * * *$ & \\
\hline \multirow{3}{*}{ Ceglédi bíborkajszi } & & vir: & gzás kezdet & & & \\
\hline & 0,994 & $563,7 * * *$ & konstans & $-98,7$ & $-11,8 * * *$ & $-2,6$ \\
\hline & & & $\mathrm{x}$ együttható & $-57,2$ & $-16,9 * * *$ & \\
\hline \multirow[t]{2}{*}{ Gönci magyar kajszi } & 0,979 & $259,7 * * *$ & konstans & $-94,8$ & $-16,2 * * *$ & $-3,7$ \\
\hline & & & $\mathrm{x}$ együttható & $-39,1$ & $-19,7 * * *$ & \\
\hline \multirow[t]{2}{*}{ Rózsakajszi C 1406} & 0,983 & $411,4 * * *$ & konstans & $-110,9$ & $-14,04 * * *$ & $-5,1$ \\
\hline & & & $\mathrm{x}$ együttható & $-31,6$ & $-20,3 * * *$ & \\
\hline \multirow{3}{*}{ Ceglédi bíborkajszi } & & & Svirágzás & & & \\
\hline & 0,982 & $328 * * *$ & konstans & $-19,3$ & $-9,6 * *$ & $-2,5$ \\
\hline & & & $\mathrm{x}$ együttható & $-27,7$ & $-14,5 * * *$ & \\
\hline \multirow[t]{2}{*}{ Gönci magyar kajszi } & 0,957 & $106,7 * *$ & konstans & $-75,4$ & $-12,5 * * *$ & $-3,5$ \\
\hline & & & $\mathrm{x}$ együttható & $-35,8$ & $-16,5^{* * *}$ & \\
\hline \multirow[t]{2}{*}{ Rózsakajszi C 1406} & 0,961 & $175,9 * * *$ & konstans & $-125,9$ & $-9,8 * * *$ & $-4,9$ \\
\hline & & & $\mathrm{x}$ együttható & $-35,9$ & $-14,6 * * *$ & \\
\hline \multirow{3}{*}{ Ceglédi bíborkajszi } & & & ágzás vége & & & \\
\hline & 0,978 & $542,6 * * *$ & konstans & $-44,2$ & $-13,04 * * *$ & $-1,6$ \\
\hline & & & $\mathrm{x}$ együttható & $-58,9$ & $-20,6 * * *$ & \\
\hline \multirow[t]{2}{*}{ Gönci magyar kajszi } & 0,923 & $76,2 * * *$ & konstans & $-99,6$ & $-20,5 * * *$ & $-2,4$ \\
\hline & & & $\mathrm{x}$ együttható & $-62,3$ & $-27,7 * * *$ & \\
\hline \multirow[t]{2}{*}{ Rózsakajszi C 1406} & 0,896 & $65,7 * *$ & konstans & $-36,8$ & $-6,5 * *$ & $-3,8$ \\
\hline & & & $\mathrm{x}$ együttható & $-22,8$ & $-17,1 * *$ & \\
\hline
\end{tabular}

$* * \mathrm{p}<0,01 ; * * * \mathrm{p}<0,001$ 
M.2.13. táblázat: 13 kajszifajta gyümölcsének fizikai paramétereit (tömeg, magasság, szélesség, vastagság) meghatározó tényezők (fajta, év) többváltozós statisztikai értékelése három különböző érettségi állapotban $(70 \%, 80 \%, 90 \%)$

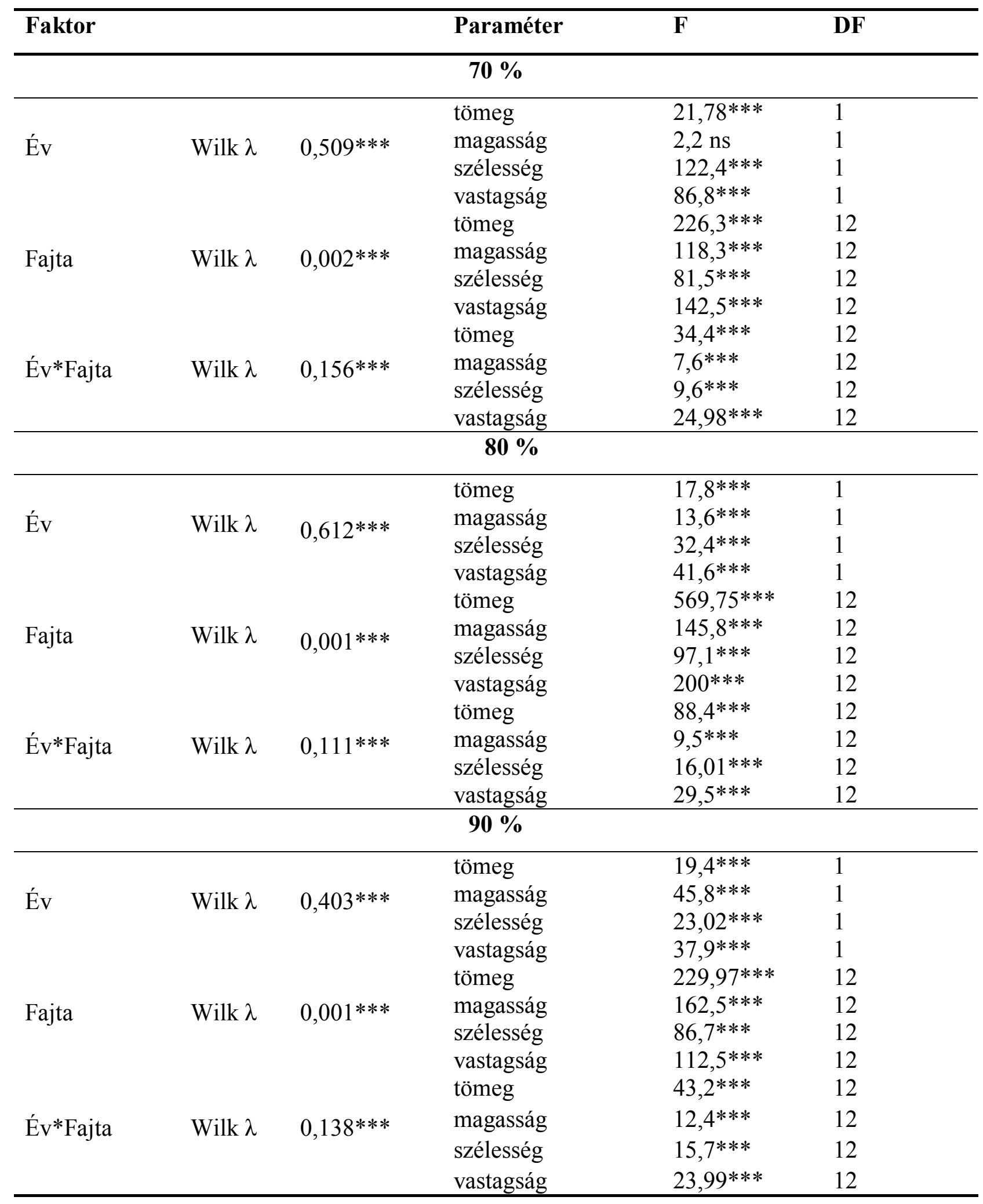

nem szignifikáns $* \mathrm{p}<0,05 \quad * * \mathrm{p}<0,01 \quad * * * \mathrm{p}<0,001$ 
M.2.14. táblázat: 13 kajszifajta gyümölcsének húskeménységét meghatározó tényezők (fajta, év) többváltozós statisztikai értékelése három különböző érettségi állapotban $(70 \%, 80 \%, 90 \%)$ a gyümölcs napos $(\mathrm{N})$ és árnyékos (Á) oldalán

\begin{tabular}{|c|c|c|c|c|c|}
\hline Faktor & & & & $\mathbf{F}$ & DF \\
\hline \multicolumn{6}{|c|}{ Húskeménység 70 \%-os érettségnél } \\
\hline \multirow{2}{*}{ Év } & \multirow{2}{*}{ Wilk $\lambda$} & \multirow{2}{*}{$0,49 * * *$} & $\mathrm{~N}$ & $243,97 * * *$ & 1 \\
\hline & & & Á & $233,74 * * *$ & 1 \\
\hline \multirow{2}{*}{ Fajta } & \multirow{2}{*}{ Wilk $\lambda$} & \multirow{2}{*}{$0,34 * * *$} & $\mathrm{~N}$ & $35,09 * * *$ & 12 \\
\hline & & & Á & $32,9 * * *$ & 12 \\
\hline \multirow{2}{*}{ Év*Fajta } & \multirow{2}{*}{ Wilk $\lambda$} & \multirow{2}{*}{$0,67 * * *$} & $\mathrm{~N}$ & $8,93 * * *$ & 12 \\
\hline & & & Á & $7,91 * * *$ & 12 \\
\hline
\end{tabular}

\begin{tabular}{lccccc}
\hline \multicolumn{5}{c}{ Húskeménység 80 \%-os érettségnél } \\
\hline \multirow{2}{*}{ Év } & Wilk $\lambda$ & $0,34 * * *$ & $\mathrm{~N}$ & $486,83 * * *$ & 1 \\
& & & Á & $282,69 * * *$ & 1 \\
\multirow{2}{*}{ Fajta } & Wilk $\lambda$ & $0,22 * * *$ & $\mathrm{~N}$ & $70,01 * * *$ & 12 \\
& & & Á & $46,18 * * *$ & 12 \\
\multirow{2}{*}{ Év*Fajta } & Wilk $\lambda$ & $0,42 * * *$ & $\mathrm{~N}$ & $25,24 * * *$ & 12 \\
& & & Á & $14,38 * * *$ & 12 \\
\hline
\end{tabular}

\begin{tabular}{lccccc}
\hline \multicolumn{5}{c}{ Húskeménység 90 \%-os érettségnél } \\
\hline \multirow{2}{*}{ Év } & Wilk $\lambda$ & $0,64 * * *$ & $\mathrm{~N}$ & $125,89 * * *$ & 1 \\
& & & Á & $59,81 * * *$ & 1 \\
\multirow{2}{*}{ Fajta } & Wilk $\lambda$ & $0,26 * * *$ & $\mathrm{~N}$ & $47,97 * * *$ & 12 \\
& & & Á & $24,49 * * *$ & 12 \\
\multirow{2}{*}{ Év*Fajta } & Wilk $\lambda$ & $0,55^{* * *}$ & $\mathrm{~N}$ & $13,2 * * *$ & 12 \\
& & & Á & $3,37 * * *$ & 12 \\
\hline
\end{tabular}

$* \mathrm{p}<0,05 \quad * * \mathrm{p}<0,01 \quad * * * \mathrm{p}<0,001$ 
M.2.15. táblázat: A vizsgált évek $(2011,2013)$ statisztikai összehasonlítása a fajták húskeménysége $\left(\mathrm{kg} / \mathrm{cm}^{2}\right)$ szerint

\begin{tabular}{ccccccc}
\hline Érettség & \multicolumn{2}{c}{$\mathbf{7 0} \%$} & \multicolumn{2}{c}{$\mathbf{8 0} \%$} & \multicolumn{2}{c}{$\mathbf{9 0} \%$} \\
\hline Fajta & $\mathrm{N}$ & $\hat{\mathrm{A}}$ & $\mathrm{N}$ & $\mathrm{A}$ & $\mathrm{N}$ & $\mathrm{A}$ \\
\hline Budapest & $* * *$ & $* * *$ & $* *$ & $* * *$ & $\mathrm{~ns}$ & $*$ \\
Gönci magyar kajszi & $* * *$ & $* * *$ & $* *$ & $\mathrm{~ns}$ & $\mathrm{~ns}$ & $*$ \\
Mandulakajszi & $* * *$ & $* * *$ & $* * *$ & $* * *$ & $\mathrm{~ns}$ & $\mathrm{~ns}$ \\
Aurora & $\mathrm{ns}$ & $*$ & $\mathrm{~ns}$ & $\mathrm{~ns}$ & & $\mathrm{~ns}$ \\
Bergarouge & $* * *$ & $* * *$ & $* * *$ & $* * *$ & $* * *$ & $* * *$ \\
Goldrich & $* * *$ & $* * *$ & $* * *$ & $* *$ & $* *$ & $*$ \\
Harcot & $* * *$ & $* * *$ & $* * *$ & $* * *$ & $* * *$ & $* * *$ \\
Harogem & $* * *$ & $* * *$ & $* * *$ & $* * *$ & $* *$ & $* *$ \\
Litoral & $* * *$ & $*$ & $*$ & $\mathrm{~ns}$ & $* * *$ & $\mathrm{~ns}$ \\
Orange Red & $\mathrm{ns}$ & $\mathrm{ns}$ & $* * *$ & $* * *$ & $\mathrm{~ns}$ & $\mathrm{~ns}$ \\
Pinkcot & $* * *$ & $* * *$ & $* * *$ & $* * *$ & $* * *$ & $*$ \\
Sylvercot & $* * *$ & $* * *$ & $* * *$ & $* * *$ & $* * *$ & $* *$ \\
Veecot & $*$ & $* * *$ & $* * *$ & $\mathrm{~ns}$ & $\mathrm{~ns}$ & $\mathrm{~ns}$ \\
\hline
\end{tabular}

${ }^{*} \mathrm{p}<0,05 * * \mathrm{p}<0,01 * * * \mathrm{p}<0,001$ ns: nem szignifikáns 
M.2.16. táblázat: 8 kajszifajta gyümölcsének húskeménységét és állományparamétereit meghatározó tényező (fajta) statisztikai értékelése három különböző érettségi állapotban $(70 \%$, $80 \%, 90 \%$ ) a gyümölcs napos $(\mathrm{N})$ és árnyékos (Á) oldalán

\begin{tabular}{|c|c|c|c|c|c|}
\hline Faktor & & & Paraméter & $\mathbf{F}$ & DF \\
\hline \multicolumn{6}{|c|}{$70 \%$} \\
\hline Fajta & Wilk $\lambda$ & $0,005 * * *$ & $\begin{array}{l}\text { húskeménység N } \\
\text { húskeménység Á } \\
\text { adhéziós erő N } \\
\text { adhéziós erő Á } \\
\text { kohéziós erő N } \\
\text { kohéziós erő Á } \\
\text { rágósság N } \\
\text { rágósság Á }\end{array}$ & $\begin{array}{l}142,127 * * * \\
22,873 * * * \\
73,670 * * * \\
27,904 * * * \\
6,768 * * * \\
4,990 * * * \\
123,411 * * * \\
20,203 * * * \\
\end{array}$ & $\begin{array}{l}8 \\
8 \\
8 \\
8 \\
8 \\
8 \\
8 \\
8\end{array}$ \\
\hline \multicolumn{6}{|c|}{$80 \%$} \\
\hline Fajta & Wilk $\lambda$ & $0,48 * * *$ & $\begin{array}{l}\text { húskeménység } \mathrm{N} \\
\text { húskeménység Á } \\
\text { adhéziós erő N } \\
\text { adhéziós erő Á } \\
\text { kohéziós erő N } \\
\text { kohéziós erő Á } \\
\text { rágósság N } \\
\text { rágósság Á }\end{array}$ & $\begin{array}{l}56,313 * * * \\
15,998^{* * *} \\
39,131 * * * \\
15,543 * * * \\
2,438 * \\
2,272 * \\
39,078 * * * \\
16,218^{* * *}\end{array}$ & $\begin{array}{l}8 \\
8 \\
8 \\
8 \\
8 \\
8 \\
8 \\
8\end{array}$ \\
\hline \multicolumn{6}{|c|}{$90 \%$} \\
\hline Fajta & Wilk $\lambda$ & $0,013 * * *$ & $\begin{array}{l}\text { húskeménység } \mathrm{N} \\
\text { húskeménység Á } \\
\text { adhéziós erő N } \\
\text { adhéziós erő Á } \\
\text { kohéziós erő N } \\
\text { kohéziós erő Á } \\
\text { rágósság N } \\
\text { rágósság Á }\end{array}$ & $\begin{array}{l}57,389 * * * \\
16,755^{* * *} \\
20,994 * * * \\
15,112 * * * \\
9,891 * * * \\
1,623 \mathrm{~ns} \\
42,793 * * * \\
16,370 * * *\end{array}$ & $\begin{array}{l}8 \\
8 \\
8 \\
8 \\
8 \\
8 \\
8 \\
8\end{array}$ \\
\hline
\end{tabular}

${ }^{*} \mathrm{p}<0,05 \quad * * \mathrm{p}<0,01 * * * \mathrm{p}<0,001$ ns: nem szignifikáns 
M.2.17. táblázat: 13 kajszifajta gyümölcsének vízoldható szárazanyagtartalmát (Brix $\left.{ }^{\circ}\right)$ meghatározó tényezők (fajta, év) statisztikai értékelése három különböző érettségi állapotban (70\%, 80\%, 90\%), a gyümölcs napos $(\mathrm{N})$ és árnyékos $(\mathrm{A})$ oldalán

\begin{tabular}{|c|c|c|c|c|c|}
\hline Faktor & & & & $\mathbf{F}$ & $\overline{\mathbf{D F}}$ \\
\hline \multicolumn{6}{|c|}{ Vízben oldható szárazanyagtartalom 70 \%-os érettségnél } \\
\hline \multirow{2}{*}{ Év } & \multirow{2}{*}{ Wilk $\lambda$} & \multirow{2}{*}{$0,94 * *$} & $\mathrm{~N}$ & $14,3 * * *$ & 1 \\
\hline & & & Á & $8,9 * *$ & 1 \\
\hline \multirow{2}{*}{ Fajta } & \multirow{2}{*}{ Wilk $\lambda$} & \multirow{2}{*}{$0,42 * * *$} & $\mathrm{~N}$ & $22,2 * * *$ & 12 \\
\hline & & & Á & $15,6 * * *$ & 12 \\
\hline \multirow{2}{*}{ Év*Fajta } & \multirow{2}{*}{ Wilk $\lambda$} & \multirow{2}{*}{$0,56 * * *$} & $\mathrm{~N}$ & $12,7 * * *$ & 12 \\
\hline & & & Á & $10,5 * * *$ & 12 \\
\hline \multicolumn{6}{|c|}{ Vízben oldható szárazanyagtartalom 80 \%-os érettségnél } \\
\hline \multirow{2}{*}{ Év } & \multirow{2}{*}{ Wilk $\lambda$} & \multirow{2}{*}{$0,79 * * *$} & $\mathrm{~N}$ & $68,6 * * *$ & 1 \\
\hline & & & Á & $16,4 * * *$ & 1 \\
\hline \multirow{2}{*}{ Fajta } & \multirow{2}{*}{ Wilk $\lambda$} & \multirow{2}{*}{$0,11 * * *$} & $\mathrm{~N}$ & $95,7 * * *$ & 12 \\
\hline & & & Á & $44,5 * * *$ & 12 \\
\hline \multirow{2}{*}{ Év*Fajta } & \multirow{2}{*}{ Wilk $\lambda$} & \multirow{2}{*}{$0,29 * * *$} & $\mathrm{~N}$ & $47,001 * * *$ & 12 \\
\hline & & & Á & $16,7 * * *$ & 12 \\
\hline
\end{tabular}

Vízben oldható szárazanyagtartalom 90 \%-os érettségnél

\begin{tabular}{llllll}
\hline Év & Wilk $\lambda$ & $0,68^{* * *}$ & $\mathrm{~N}$ & $103,2^{* * *}$ & 1 \\
& & & $\mathrm{~A}$ & $24,2^{* * *}$ & 1 \\
\multirow{2}{*}{ Fajta } & Wilk $\lambda$ & $0,15^{* * *}$ & $\mathrm{~N}$ & $77,9 * * *$ & 12 \\
& & & Á & $24,5 * * *$ & 12 \\
Év*Fajta & Wilk $\lambda$ & $0,33^{* * *}$ & $\mathrm{~N}$ & $32,1 * * *$ & 12 \\
& & & Á & $10,97 * * *$ & 12 \\
\hline
\end{tabular}

$\mathrm{p}<0,1 * \mathrm{p}<0,05 * * \mathrm{p}<0,01 * * * \mathrm{p}<0,001$ 
M.2.18. táblázat: A vizsgált évek $(2011,2013)$ statisztikai összehasonlítása 13 kajszifajta vízoldható szárazanyagtartalma $\left(\mathrm{Brix}^{\circ}\right)$ szerint

\begin{tabular}{lllllll}
\hline Érettség & $\mathbf{7 0} \%$ & $\mathbf{8 0} \%$ & \multicolumn{2}{l}{$\mathbf{9 0} \%$} \\
\hline Fajta & $\mathbf{N}$ & $\mathbf{A}$ & $\mathbf{N}$ & $\mathbf{A}$ & $\mathbf{N}$ & $\mathbf{A}$ \\
\hline Budapest & $\mathrm{ns}$ & $\mathrm{ns}$ & $* * *$ & $*$ & $* * *$ & $*$ \\
Gönci magyar kajszi & $\mathrm{ns}$ & $\mathrm{ns}$ & $* * *$ & $* * *$ & $* * *$ & $* * *$ \\
Mandulakajszi & $* * *$ & $* * *$ & $* * *$ & $\mathrm{~ns}$ & $\mathrm{~ns}$ & $\mathrm{~ns}$ \\
Aurora & $* * *$ & $* * *$ & $* * *$ & $* * *$ & $\mathrm{~ns}$ & $*$ \\
Bergarouge & $\mathrm{ns}$ & $\mathrm{ns}$ & $*$ & $\mathrm{~ns}$ & $\mathrm{~ns}$ & $\mathrm{~ns}$ \\
Goldrich & $* * *$ & $* * *$ & $* * *$ & $* * *$ & $* * *$ & $* * *$ \\
Harcot & $* * *$ & $*$ & $* * *$ & $* * *$ & $*$ & $\mathrm{~ns}$ \\
Harogem & $\mathrm{ns}$ & $\mathrm{ns}$ & $\mathrm{ns}$ & $\mathrm{ns}$ & $* * *$ & $* *$ \\
Litoral & $* * *$ & $* * *$ & $\mathrm{~ns}$ & $\mathrm{~ns}$ & $\mathrm{~ns}$ & $\mathrm{~ns}$ \\
Orange Red & $\mathrm{ns}$ & $*$ & $\mathrm{~ns}$ & $\mathrm{~ns}$ & $\mathrm{~ns}$ & $\mathrm{~ns}$ \\
Pinkcot & $\mathrm{ns}$ & $\mathrm{ns}$ & $\mathrm{ns}$ & $\mathrm{ns}$ & $\mathrm{ns}$ & $* * *$ \\
Sylvercot & $\mathrm{ns}$ & $\mathrm{ns}$ & $* * *$ & $*$ & $* * *$ & $* * *$ \\
Veecot & $* * *$ & $* * *$ & $* * *$ & $* * *$ & $* * *$ & $* * *$ \\
\hline \multirow{2}{*}{$\mathrm{p}<0,05$} & $* * \mathrm{p}<0,01$ & $* * *$ & $\mathrm{p}<0,001 \mathrm{~ns}$ & \\
& & & & & & \\
\hline
\end{tabular}

M.2.19. táblázat: 7 kajszifajta gyümölcsének cukor komponenseit (szacharóz, glükóz, fruktóz, D-szorbitol) meghatározó tényezők (fajta, év) többváltozós statisztikai 80\%-os érettségi állapotban

\begin{tabular}{|c|c|c|c|c|c|}
\hline Faktor & & & Paraméter & $\mathbf{F}$ & DF \\
\hline \multicolumn{6}{|c|}{$80 \%$} \\
\hline \multirow{4}{*}{ Év } & \multirow{4}{*}{ Wilk $\lambda$} & \multirow{4}{*}{$<0,001 * * *$} & szacharóz & $995,01 * * *$ & 1 \\
\hline & & & glükóz & $134896,6 * * *$ & 1 \\
\hline & & & fruktóz & $108861 * * *$ & 1 \\
\hline & & & D-szorbitol & $614,6^{* * *}$ & 1 \\
\hline \multirow{4}{*}{ Fajta } & \multirow{4}{*}{ Wilk $\lambda$} & \multirow{4}{*}{$<0,001 * * *$} & szacharóz & $93087,4 * * *$ & 6 \\
\hline & & & glükóz & $8684,3 * * *$ & 6 \\
\hline & & & fruktóz & $4221,3 * * *$ & 6 \\
\hline & & & D-szorbitol & $4855,9 * * *$ & 6 \\
\hline \multirow{4}{*}{ Év*Fajta } & \multirow{4}{*}{ Wilk $\lambda$} & \multirow{4}{*}{$<0,001 * * *$} & szacharóz & $168224,7 * * *$ & 6 \\
\hline & & & glükóz & $165614,7 * * *$ & 6 \\
\hline & & & fruktóz & $3686,3 * * *$ & 6 \\
\hline & & & D-szorbitol & $1814,6^{* * *}$ & 6 \\
\hline
\end{tabular}


M.2.20. táblázat 7 kajszifajta gyümölcsének sav komponenseit (almasav, citromsav, borostyánkősav) meghatározó tényezők (fajta, év) többváltozós statisztikai értékelése 80\%-os érettségi állapotban

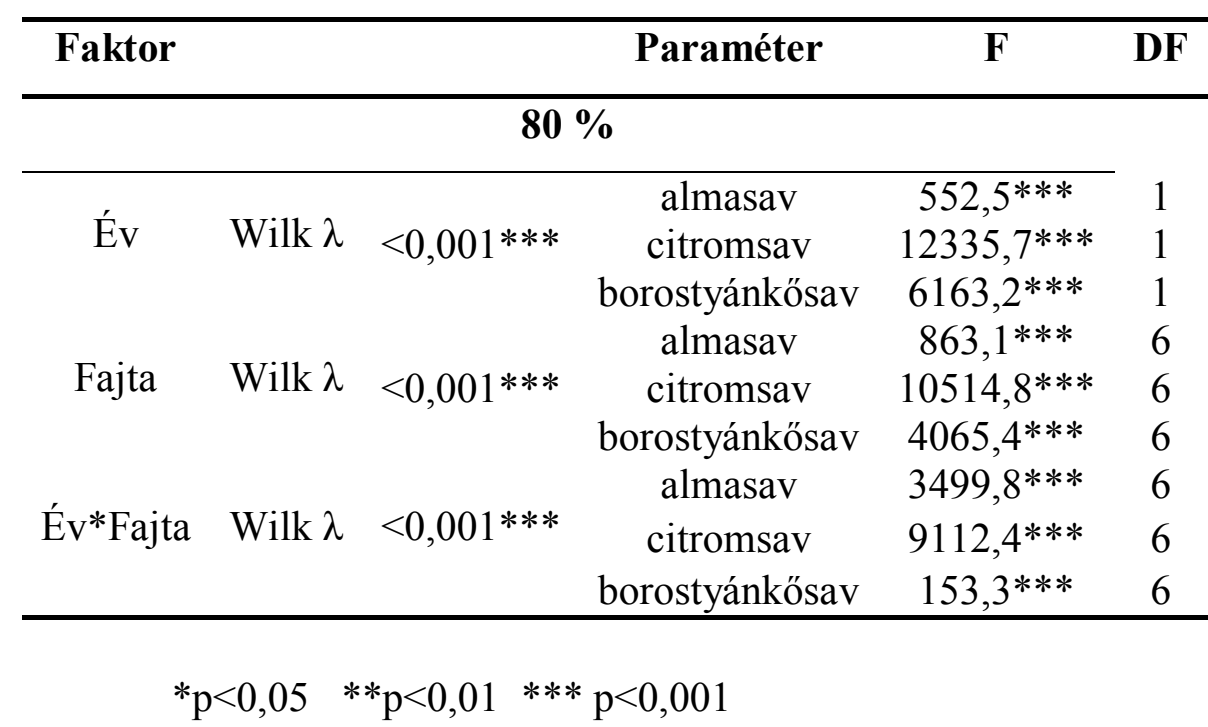


M.2.21. táblázat A vizsgált fajták húskeménységének és vízoldható szárazanyagtartalmányak alakulására alkalmazott modellek (modell 9; a: telítődési, b: logisztikus) paraméterei, valamint ezekre a paraméterekre vonatkozó statisztikai eredmények 2011-ben: a determinációs együttható (R2) értéke, a modellre vonatkozó ANOVA F-értéke és a paraméterekre vonatkozó t-próbák, valamint ezek szignifikancia szintjei

\begin{tabular}{|c|c|c|c|}
\hline $\begin{array}{c}\text { Gönci magyar kajszi } \\
\text { (a) }\end{array}$ & Becslés & $\mathbf{t}$ & $\mathbf{p}$ \\
\hline$\overline{p_{1}}$ & 8,605 & 34,02 & $* * *$ \\
\hline $\mathrm{p}_{2}$ & $-10,2$ & 10,4 & $* * *$ \\
\hline $\mathrm{p}_{3}$ & 0,254 & 5,05 & $* * *$ \\
\hline $\mathrm{R}^{2}=0,96 * * *$ & & $\mathrm{~F}=556,3 * * *$ & \\
\hline Goldrich (a) & Becslés & $\mathbf{t}$ & $\mathbf{p}$ \\
\hline $\mathrm{p}_{1}$ & 43,3 & 2,62 & $* *$ \\
\hline $\mathrm{p}_{2}$ & $-43,5$ & $-2,89$ & $* *$ \\
\hline $\mathrm{p}_{3}$ & 0,821 & 2,9 & $* *$ \\
\hline $\mathrm{R}^{2}=0,96 * * *$ & & $\mathrm{~F}=62,4 * * *$ & \\
\hline Pinkcot (b) & Becslés & $\mathbf{t}$ & $\mathbf{p}$ \\
\hline $\mathrm{p}_{1}$ & 7,4 & 25,7 & $* * *$ \\
\hline $\mathrm{p}_{3}$ & 1,2 & 8,07 & $* * *$ \\
\hline $\mathrm{p}_{4}$ & 14,5 & 131,5 & $* * *$ \\
\hline $\mathrm{R}^{2}=0,933 * * *$ & & $\mathrm{~F}=1211,9 * * *$ & \\
\hline Sylvercot (b) & Becslés & $\mathbf{t}$ & $\mathbf{p}$ \\
\hline $\mathrm{p}_{1}$ & 6,96 & 4,1 & $* * *$ \\
\hline $\mathrm{p}_{3}$ & 0,93 & 3,89 & $* * *$ \\
\hline $\mathrm{p}_{4}$ & 12,3 & 20,2 & $* * *$ \\
\hline $\mathrm{R}^{2}=0,71 * * *$ & & $\mathrm{~F}=120,73 * * *$ & \\
\hline Veecot (b) & Becslés & $\mathbf{t}$ & $\mathbf{p}$ \\
\hline $\mathrm{p}_{1}$ & 13,1 & 13,7 & $* * *$ \\
\hline $\mathrm{p}_{3}$ & 0,61 & 9,1 & $* * *$ \\
\hline $\mathrm{p}_{4}$ & 12,96 & 40,1 & $* * *$ \\
\hline $\mathrm{R}^{2}=0,92 * * *$ & & $\mathrm{~F}=537,5 * * *$ & \\
\hline
\end{tabular}

$* * * \mathrm{p}<0,001 ; * * \mathrm{p}<0,01$ 
M.2.22. táblázat: A vizsgált fajták húskeménységének és vízoldható szárazanyagtartalmányak alakulására alkalmazott modellek (modell 9; a: telítődési, b: logisztikus) paraméterei, valamint ezekre a paraméterekre vonatkozó statisztikai eredmények 2013-ban: a determinációs együttható $\left(\mathrm{R}^{2}\right)$ értéke, a modellre vonatkozó ANOVA F-értéke és a paraméterekre vonatkozó t-próbák, valamint ezek szignifikancia szintjei

\begin{tabular}{|c|c|c|c|}
\hline $\begin{array}{c}\text { Gönci magyar kajszi } \\
\text { (a) }\end{array}$ & Becslés & $\mathbf{t}$ & $\mathbf{p}$ \\
\hline $\mathrm{p}_{1}$ & 4,5 & 31,7 & $* * *$ \\
\hline $\mathrm{p}_{2}$ & $-18,7$ & -1 & ns \\
\hline $\mathrm{p}_{3}$ & 0,029 & 0,89 & ns \\
\hline $\mathrm{R}^{2}=0,944 * * *$ & & $\mathrm{~F}=520,9 * * *$ & \\
\hline Goldrich (a) & Becslés & $\mathbf{t}$ & $\mathbf{p}$ \\
\hline $\mathrm{p}_{1}$ & 8,2 & 10,9 & $* * *$ \\
\hline $\mathrm{p}_{2}$ & $-8,9$ & $-17,8$ & $* * *$ \\
\hline $\mathrm{p}_{3}$ & 0,21 & 4,8 & $* * *$ \\
\hline $\mathrm{R}^{2}=0,924 * * *$ & & $\mathrm{~F}=319 * * *$ & \\
\hline Pinkcot (b) & Becslés & $\mathbf{t}$ & $\mathbf{p}$ \\
\hline $\mathrm{p}_{1}$ & 3,9 & 15,6 & $* * *$ \\
\hline $\mathrm{p}_{2}$ & 0,351 & 3,5 & $* *$ \\
\hline $\mathrm{p}_{3}$ & 5,2 & 4,06 & $* * *$ \\
\hline $\mathrm{p}_{4}$ & 13,02 & 199,6 & $* * *$ \\
\hline $\mathrm{R}^{2}=0,903 * * *$ & & $\mathrm{~F}=105,99 * * *$ & \\
\hline Sylvercot (a) & Becslés & $\mathbf{t}$ & $\mathbf{p}$ \\
\hline $\mathrm{p}_{1}$ & 4,4 & 9,41 & $* * *$ \\
\hline $\mathrm{p}_{2}$ & $-4,4$ & $-10,4$ & $* * *$ \\
\hline $\mathrm{p}_{3}$ & 0,64 & 5,5 & $* * *$ \\
\hline $\mathrm{R}^{2}=0,85^{* * *}$ & & $\mathrm{~F}=89,97 * * *$ & \\
\hline Veecot (a) & Becslés & $\mathbf{t}$ & $\mathbf{p}$ \\
\hline $\mathrm{p}_{1}$ & 17,9 & 9,4 & $* * *$ \\
\hline $\mathrm{p}_{2}$ & -17 & $-11,08$ & $* * *$ \\
\hline $\mathrm{p}_{3}$ & 0,33 & 5,7 & $* * *$ \\
\hline $\mathrm{R}^{2}=0,89 * * *$ & & $\mathrm{~F}=335,5 * * *$ & \\
\hline
\end{tabular}

$* * * \mathrm{p}<0,001 ; * * \mathrm{p}<0,01 ;$ ns: nincs szignifikáns különbség 
M.2.23. táblázat: 4 kajszifajta gyümölcsének polifenol-tartalmát meghatározó tényezők (fajta, év) statisztikai értékelése $80 \%$-os érettségi állapotban

\begin{tabular}{ccc}
\hline Változó & $\mathbf{F}$ & DF \\
\hline & $\mathbf{8 0 \% - o s ~ e ́ r e t t s e ́ g ~}$ & \\
\hline Év & $688,9 * * *$ & 1 \\
Fajta & $522,96 * * *$ & 3 \\
Év*Fajta & $179,7 * * *$ & 3 \\
\hline \multirow{2}{*}{$*{ }^{*}<0,05 \quad * * \mathrm{p}<0,01$} & $* * * \mathrm{p}<0,001$ &
\end{tabular}

M.2.24. táblázat: A vizsgált évek $(2011,2013)$ statisztikai összehasonlítása 4 kajszifajta polifenol tartalma alapján

\begin{tabular}{cc}
\hline Fajta & $\mathbf{8 0 \%}$ \\
\hline Gönci magyar kajszi & $* * *$ \\
Pinkcot & + \\
Sylvercot & $* * *$ \\
Veecot & $* * *$ \\
\hline
\end{tabular}

$+\mathrm{p}<0,1 * \mathrm{p}<0,05 * * \mathrm{p}<0,01 * * * \mathrm{p}<0,001$

M.2.25. táblázat: 4 kajszifajta gyümölcsének ß-karotin tartalmát meghatározó tényezők (fajta, év) statisztikai értékelése $80 \%$-os érettségi állapotban

\begin{tabular}{ccc}
\hline Változó & F & DF \\
\hline Év & $\mathbf{8 0 \% - 0 s ~ e ́ r e t t s e ́ g ~}$ & \\
\hline Fajta & $46,8^{* * *}$ & 1 \\
Év*Fajta & ns & 4 \\
\hline
\end{tabular}

$* \mathrm{p}<0,05 \quad * * \mathrm{p}<0,01 * * * \mathrm{p}<0,001, \mathrm{~ns}:$ nem szignifikáns 
M.2.26. táblázat: A vizsgált évek $(2011,2013)$ statisztikai összehasonlítása 4 kajszifajta ßkarotin tartalma alapján

\begin{tabular}{cc}
\hline Fajta & $\mathbf{8 0 \%}$ \\
\hline Gönci magyar kajszi & $* * *$ \\
Pinkcot & + \\
Sylvercot & $* * *$ \\
Veecot & $* *$ \\
\hline
\end{tabular}

$+\mathrm{p}<0,1 * \mathrm{p}<0,05 \quad * * \mathrm{p}<0,01 * * * \mathrm{p}<0,001$ 


\section{M.3. Ábrák}

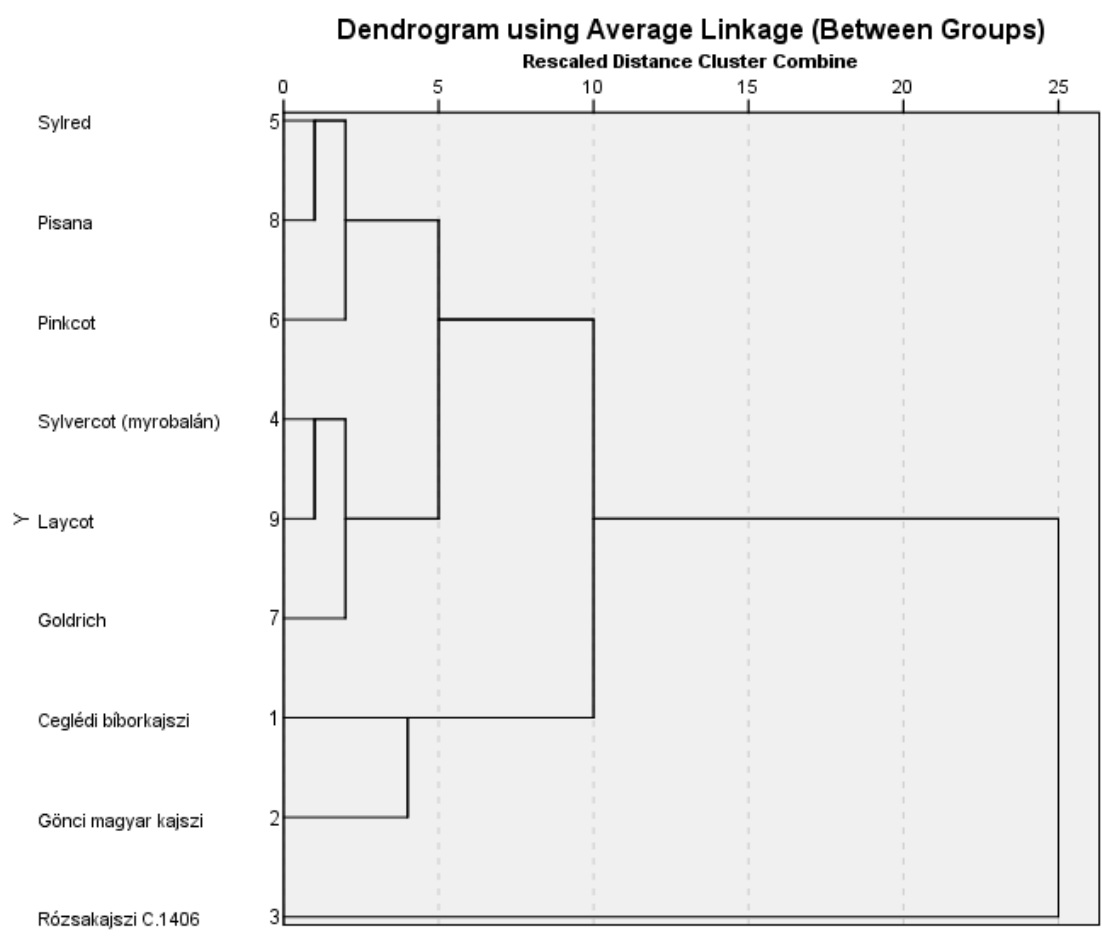

M.3.1. ábra: Kajszifajták fagytürésének értékelés hierarchikus klaszteranalízis segítségével 2010/2011

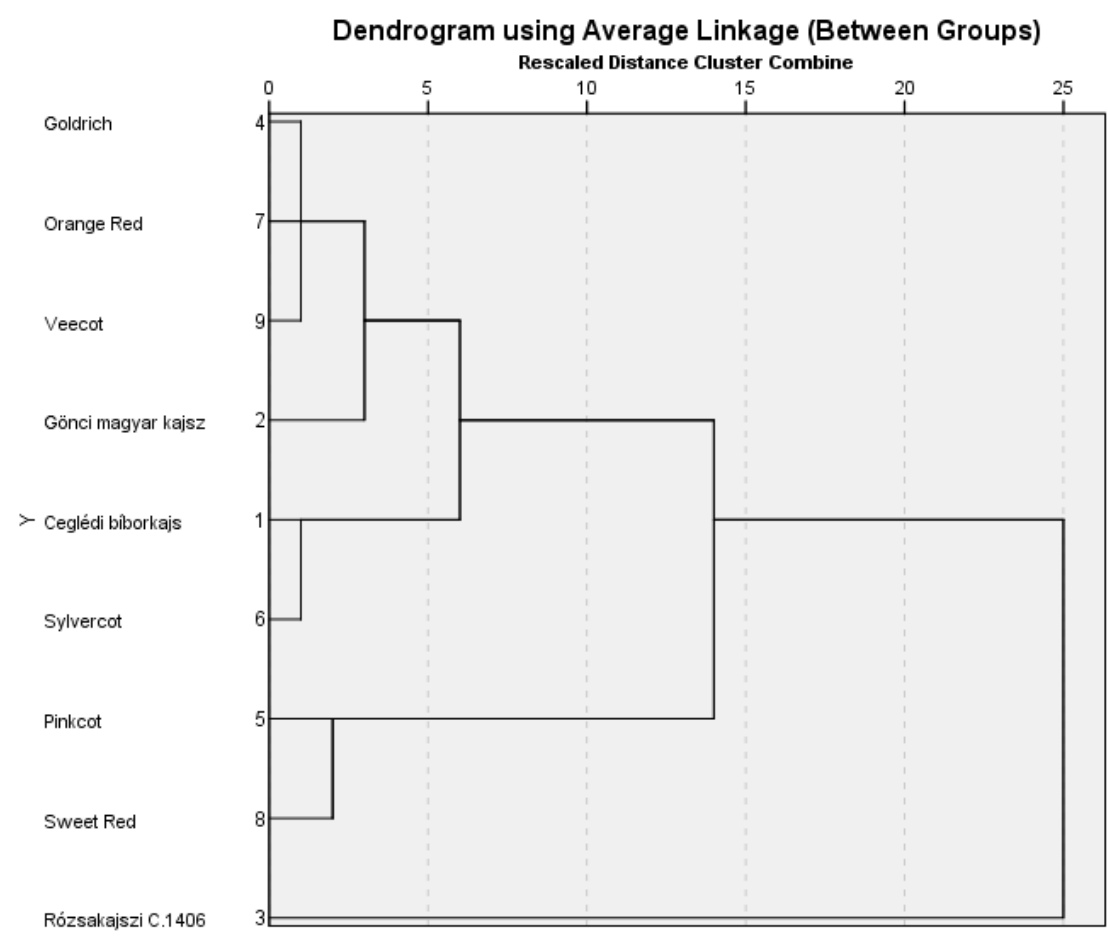

M.3.2. ábra: Kajszifajták fagytürésének értékelés hierarchikus klaszteranalízis segítségével 2011/2012 


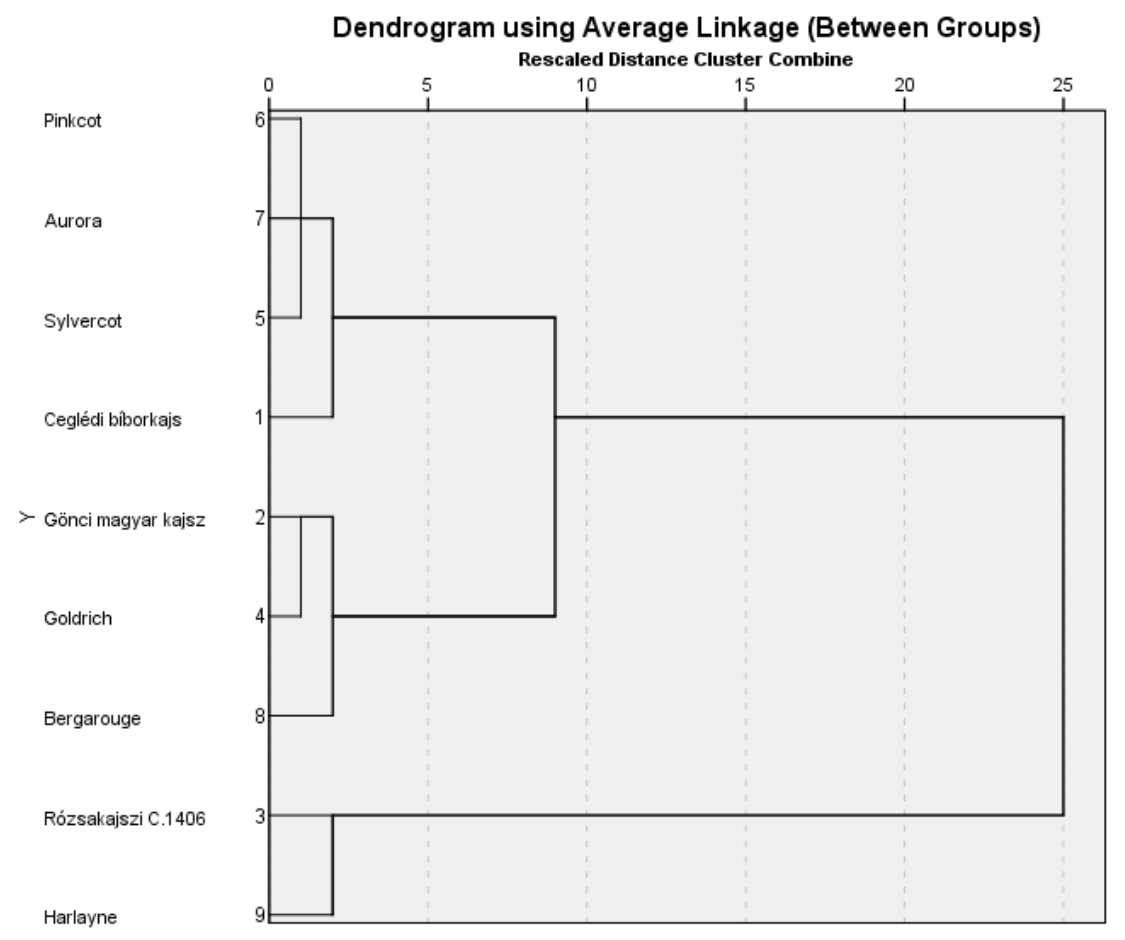

M.3.3. ábra: Kajszifajták fagytűrésének értékelés hierarchikus klaszteranalízis segítségével 2012/2013

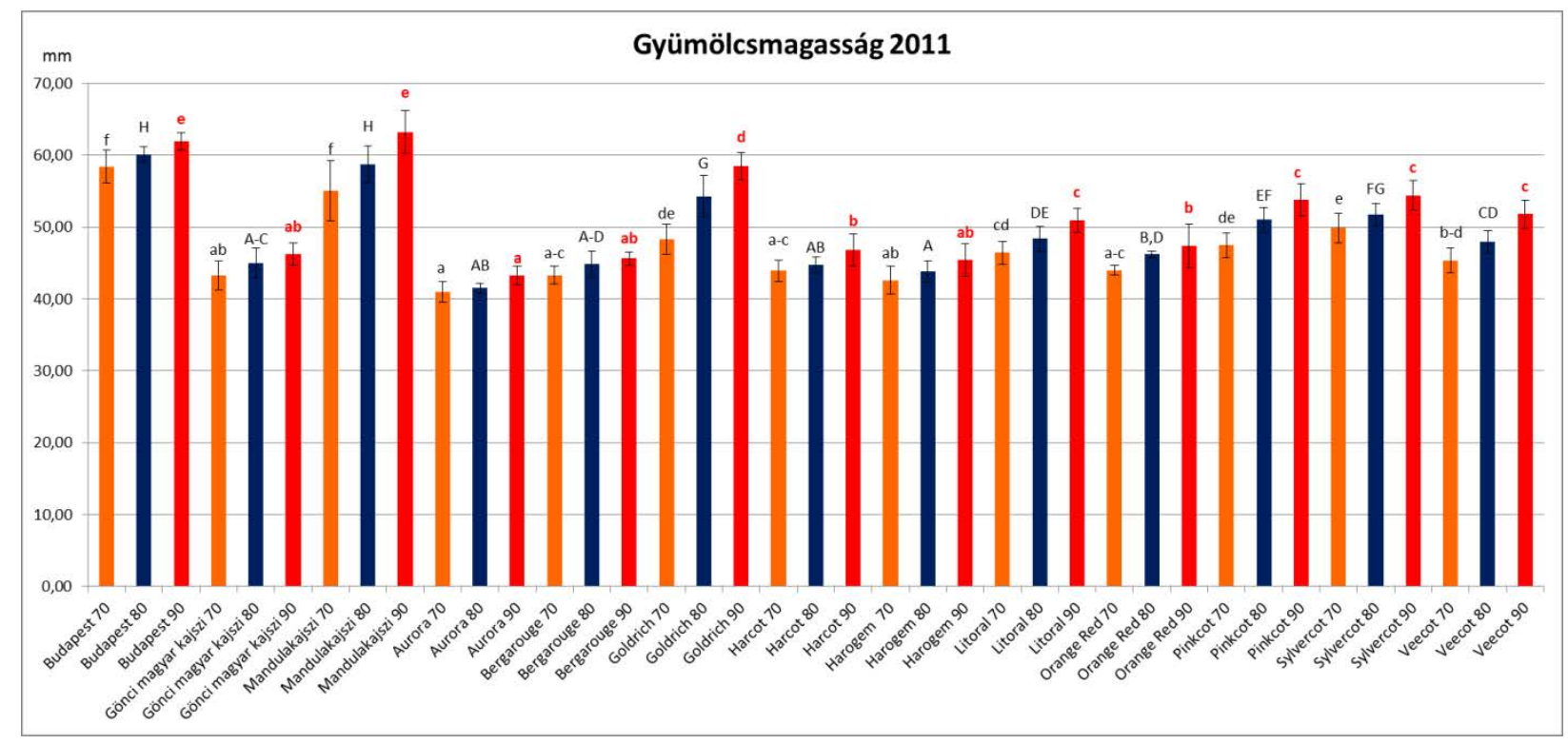

M.3.4. ábra: A vizsgált kajszifajták gyümölcseinek magassága 2011-ben. Az oszlopok magassága a mérések átlagát, a vonalak a szórást mutatják $(\mathrm{n}=10)$. A különböző betük szignifikánsan különbözö csoportokat jelölnek a Games-Howell- /Tukey-féle post hoc teszt szerint $\mathrm{p}<0,05$ szinten (kisbetü: 70\%-os érettség; nagybetü: $80 \%$-os érettség; piros kisbetű $90 \%$-os érettség). 


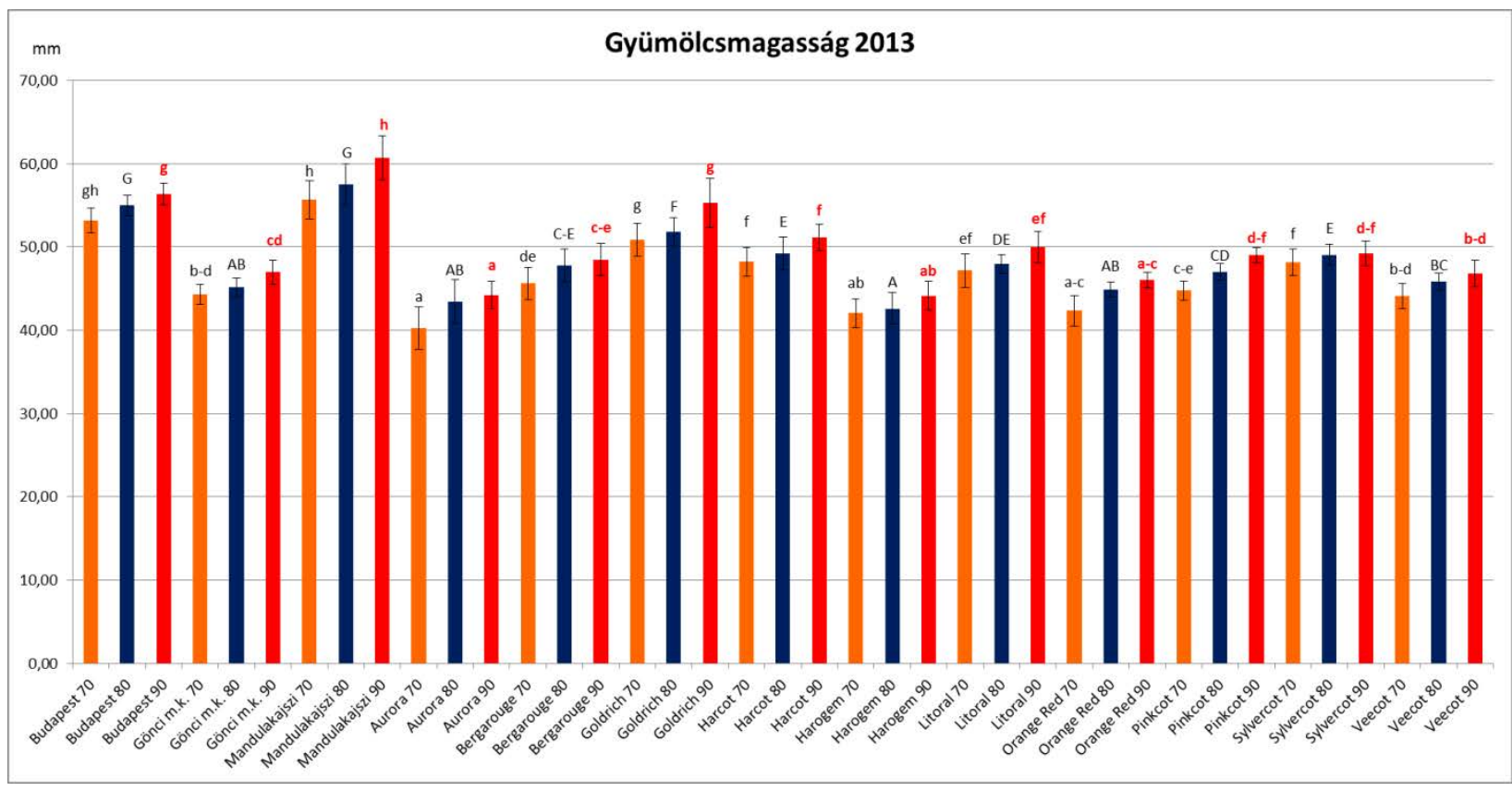

M.3.5. ábra: A vizsgált kajszifajták gyümölcseinek magassága 2013-ban. Az oszlopok magassága a mérések átlagát, a vonalak a szórást mutatják $(\mathrm{n}=10)$. A különböző betük szignifikánsan különbözö csoportokat jelölnek a Games-Howell- /Tukey-féle post hoc teszt szerint $\mathrm{p}<0,05$ szinten (kisbetü: 70\%-os érettség; nagybetű: 80 \%-os érettség; piros kisbetű 90 \%-os érettség)

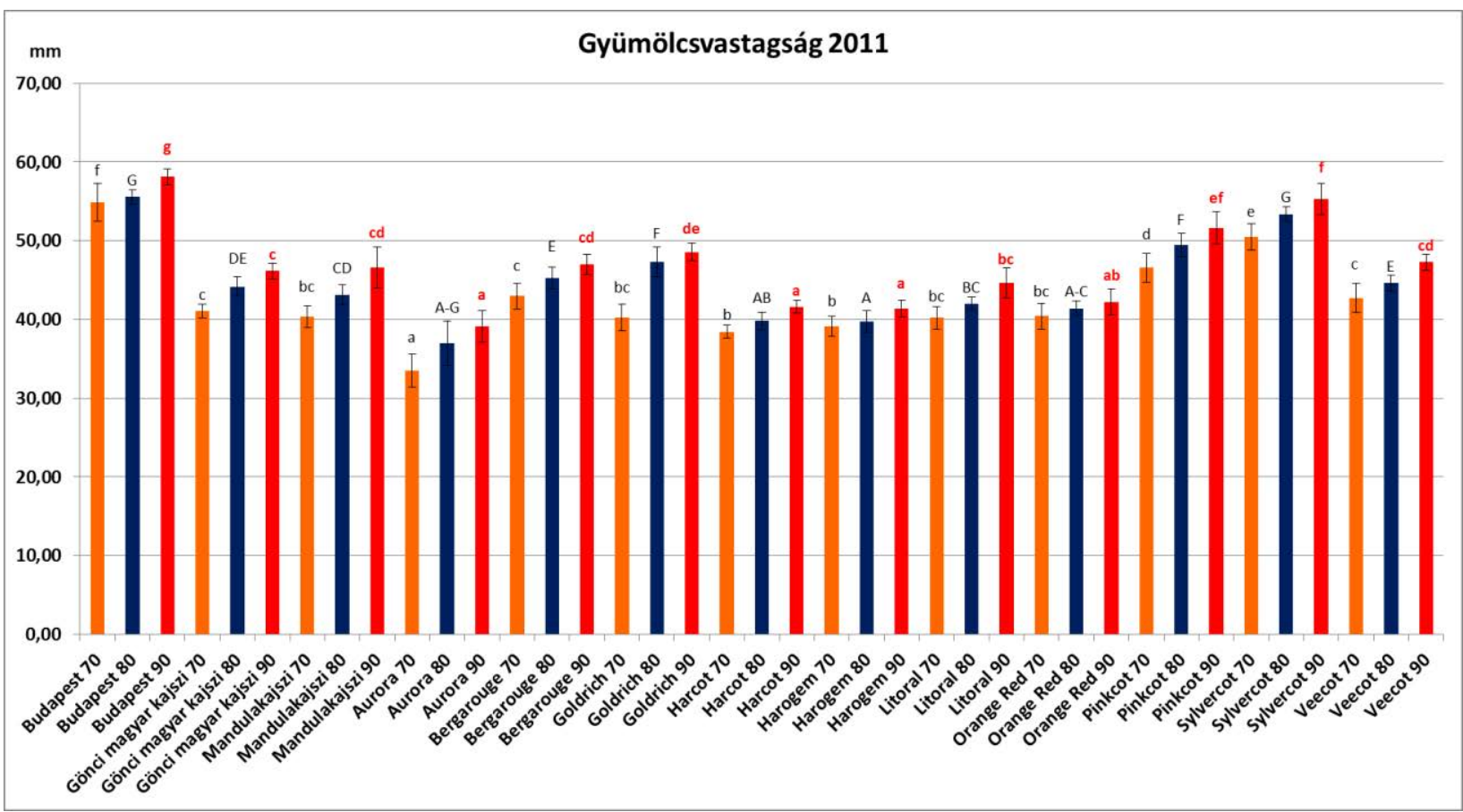

M.3.6. ábra: A vizsgált kajszifajták gyümölcseinek vastagsága 2011-ben. Az oszlopok magassága a mérések átlagát, a vonalak a szórást mutatják $(\mathrm{n}=10)$. A különböző betűk szignifikánsan különbözö csoportokat jelölnek a Games-Howell- /Tukey-féle post hoc teszt szerint $\mathrm{p}<0,05$ szinten (kisbetü: 70\%-os érettség; nagybetü: 80 \%-os érettség; piros kisbetü 90 \%-os érettség) 


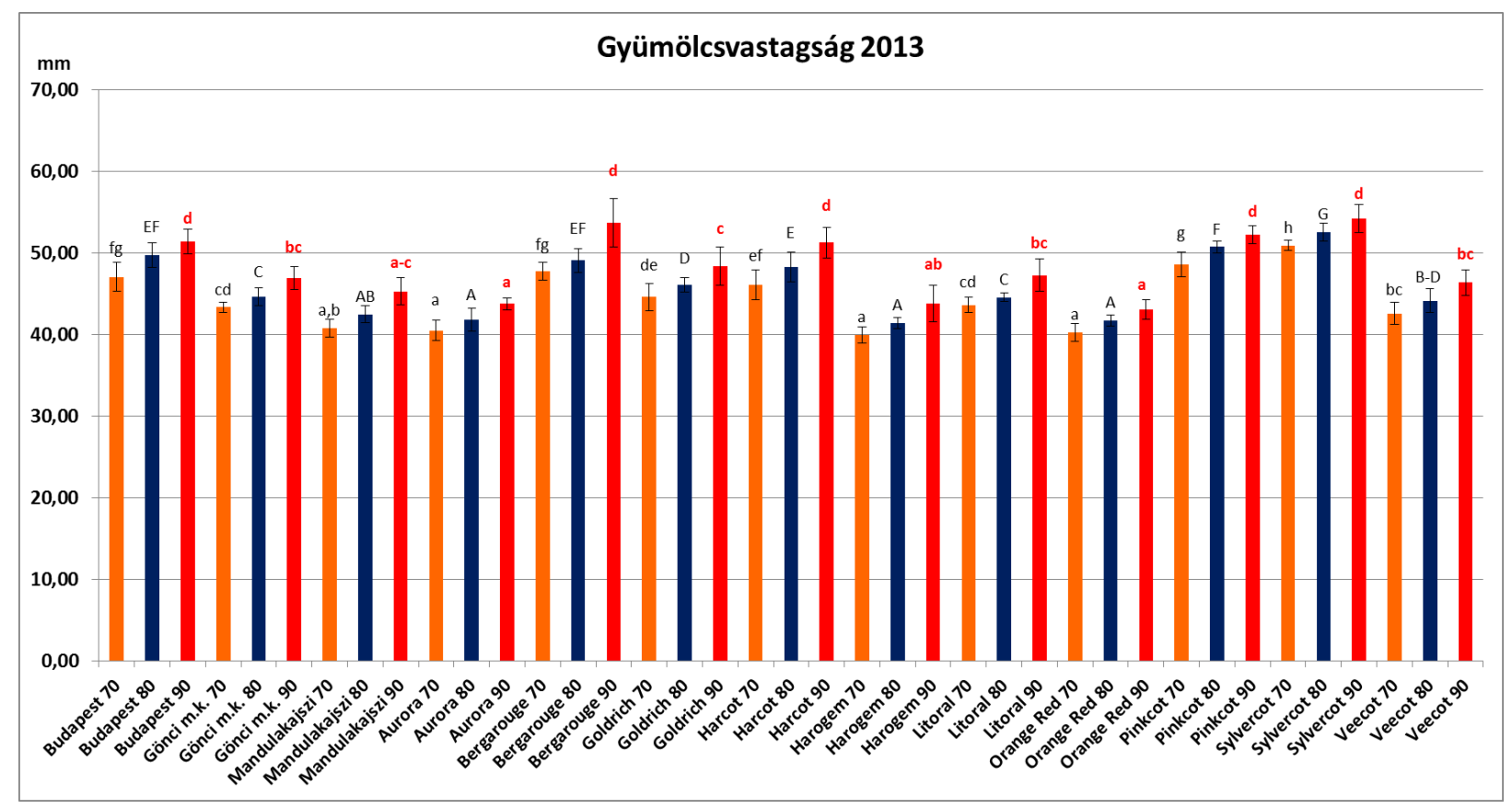

M.3.7. ábra: A vizsgált kajszifajták gyümölcseinek vastagsága 2013. Az oszlopok magassága a mérések átlagát, a vonalak a szórást mutatják ( $\mathrm{n}=10)$. A különböző betűk szignifikánsan különböző csoportokat jelölnek a Games-Howell- /Tukey-féle post hoc teszt szerint p $<0,05$ szinten (kisbetü: 70\%-os érettség; nagybetü: 80 \%-os érettség; piros kisbetü 90 \%-os érettség)

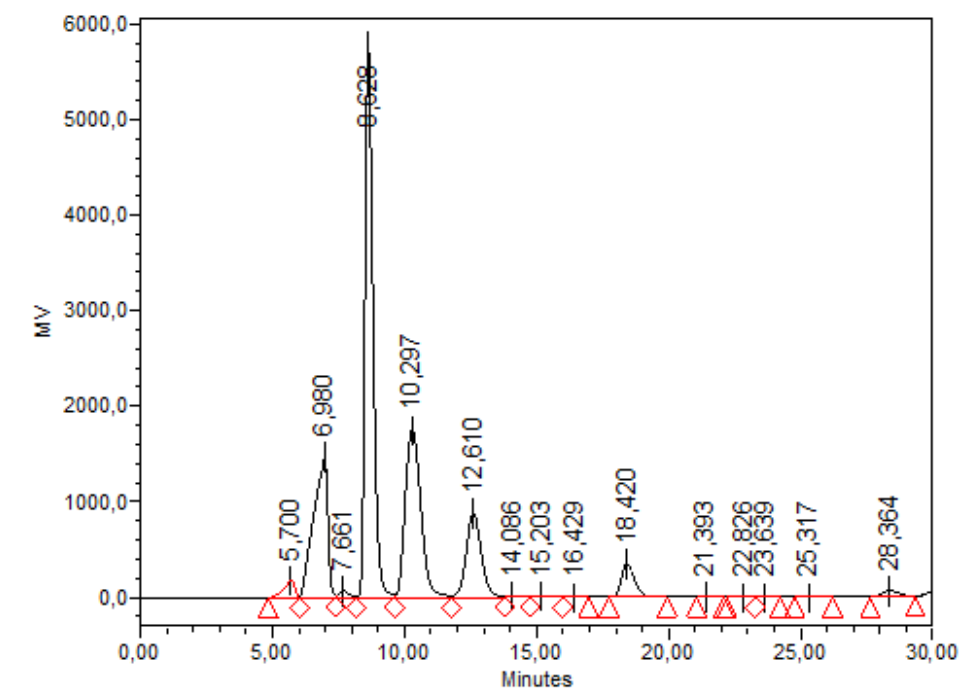

M.3.8. ábra: Szénhidrátok kromatogramja 


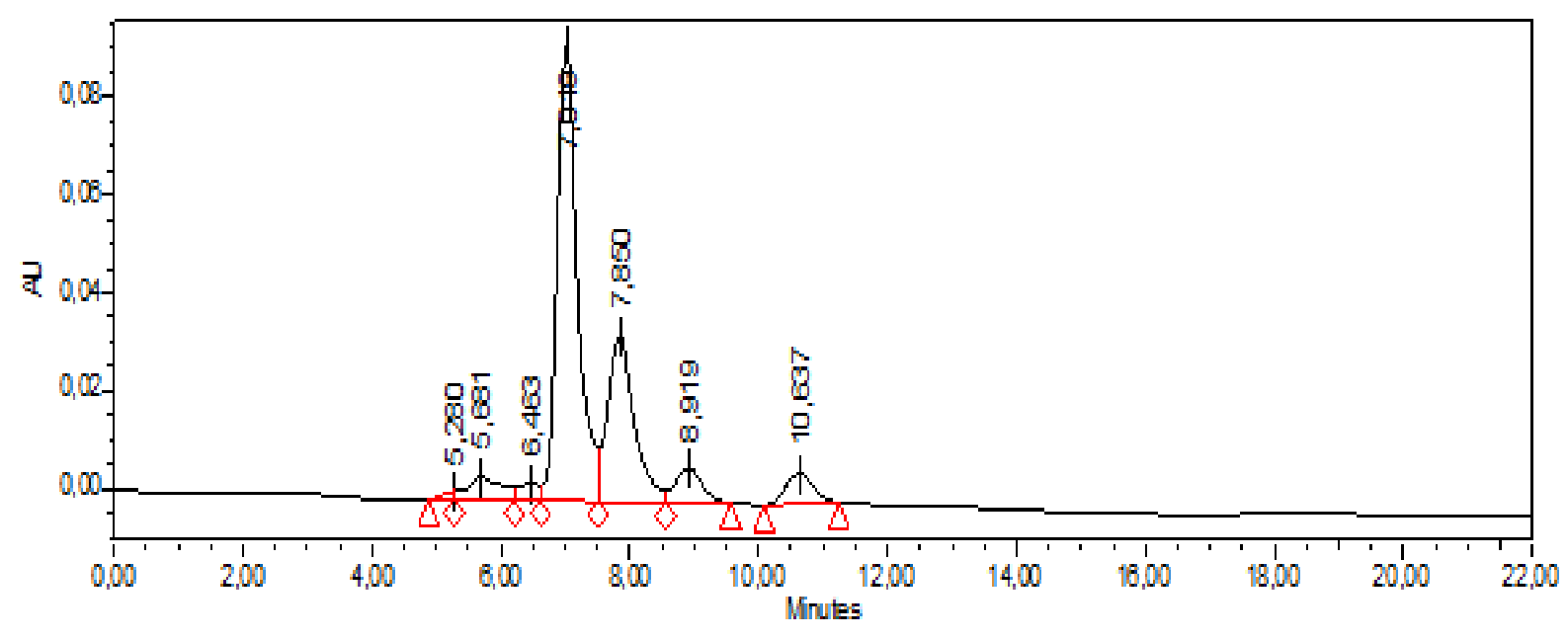

M.3.9. ábra: Szerves savak kromatogramja 


\section{KÖSZÖNETNYILVÁNÍTÁS}

Ezúton szeretnék köszönetet mondani témavezetőmnek, Dr. Szalay Lászlónak, aki kiemelkedő szakmai tudásával segítette munkámat és dolgozatom elkészítését. Köszönet illeti Dr. Tóth Magdolna tanszékvezető asszonyt, aki végig támogatta és segítette munkánkat és publikációink megjelenését.

Köszönet illeti továbbá Dr. Ficzek Gittát az állománymérés, ß-karotin és polifenol mérésekben nyújtott segítségéért, valamint szakmai tanácsaiért. Köszönöm Dr. Végvári Györgynek és Hajagos Anikónak a HPLC mérések elvégzését és szakmai tanácsait. Köszönöm továbbá Újvári Margit és Szabados Györgyi laboratóriumi mérésekben nyújtott asszisztenciáját. Köszönöm Gál Erzsébetnek a fagytürési minták megszedésében nyújtott segítségét.

Külön köszönet illeti Dr. Ladányi Mártát a statisztikai elemzésekben nyújtott önzetlen segítségéért.

Hálás vagyok a tanszék minden volt és jelenlegi munkatársának, akik támogattak dolgozatom elkészítésében.

Végül, de nem utolsó sorban köszönöm családomnak, különösen férjemnek támogatását és folyamatos biztatását.

Kutató munkámat a GOP-2009-1.1.1. „A versenyképes kajszitermesztést megalapozó innováció megvalósítása Mór térségében” címü pályázat, illetve hazai és nemzetközi génbanki pályázatok támogatták. 